NATALIE MICHELE DE SOUZA

AVALIAÇÃO DA ATIVIDADE IMUNOGÊNICA DE TRÊS PROTEÍNAS DE LEPTOSPIRA INTERROGANS EXPRESSAS EM ESCHERICHIA COLI

Dissertação apresentada ao Programa de Pós-Graduação Interunidades em Biotecnologia USP/Instituto Butantan/IPT, para obtenção do Título de Mestre em Biotecnologia. 
NATALIE MICHELE DE SOUZA

AVALIAÇÃO DA ATIVIDADE IMUNOGÊNICA DE TRÊS PROTEÍNAS DE LEPTOSPIRA INTERROGANS EXPRESSAS EM ESCHERICHIA COLI

Dissertação apresentada ao Programa de Pós-Graduação Interunidades em Biotecnologia USP/Instituto Butantan/IPT, para obtenção do Título de Mestre em Biotecnologia.

Área de concentração: Biotecnologia.

Orientador: Dra. Ana Lucia Tabet Oller do Nascimento

Versão original 
DADOS DE CATALOGAÇÃO NA PUBLICAÇÃO (CIP)

Serviço de Biblioteca e Informação Biomédica do

Instituto de Ciências Biomédicas da Universidade de São Paulo

(C) reprodução total

Souza, Natalie Michele de.

Avaliação da atividade imunogênicas de três proteínas de Leptospira interrogans expressas em Escherichia coli / Natalie Michele de Souza. -- São Paulo, 2013.

Orientador: Profa. Dra. Ana Lúcia Tabet Oller do Nascimento.

Dissertação (Mestrado) - Universidade de São Paulo. Instituto de Ciências Biomédicas. Programa de Pós-Graduação Interunidades em Biotecnologia USP/IPT/Instituto Butantan. Área de concentração: Biotecnologia. Linha de pesquisa: Genômica funcional.

Versão do título para o inglês: Immunogenic activity evaluation of three proteins of Leptospira interrogans expressed in Escherichia coli.

1. Leptospirose 2. Proteínas recombinantes 3. Vacinas

4. Genomas 5. Leptospira interrogans 6. Spirochaetales I.

Nascimento, Profa. Dra. Ana Lucia Tabet Oller do II. Universidade de São Paulo. Instituto de Ciências Biomédicas. Programa de Pós-

Graduação Interunidades em Biotecnologia USP/IPT/Instituto Butantan III. Título. 
Candidato(a): $\quad$ Natalie Michele de Souza.

Título da Dissertação: $\quad$ Avaliação da atividade imunogênicas de três proteínas de Leptospira interrogans expressas em Escherichia coli.

Orientador(a): $\quad$ Profa. Dra. Ana Lúcia Tabet Oller do Nascimento.

A Comissão Julgadora dos trabalhos de Defesa da Dissertação de Mestrado, em sessão pública realizada a .................................................., considerou
( ) Aprovado(a)
( ) Reprovado(a)

Examinador(a): Assinatura:

Nome:

Instituição:

Examinador(a): Assinatura:

Nome:

Instituição:

Presidente: Assinatura:

Nome:

Instituição: 


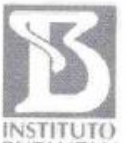

COMISSÃO DE ÉTICA NO USO DE ANIMAIS

INSTITUTO BUTANTAN

Av. Dr. Vital Brazil, 1500, CEP 05503-900, São Paulo, SP, Brazil Telefone: (55) (011) 3726-7222 ramal 2163 - Fax: (55) (011) 3726-1505

\section{CERTIFICADO}

Certificamos que o projeto intitulado "Avaliação da atividade imunogênica de duas proteínas preditas de membrana de Leptospira interrogans expressas em Escherichia coli", protocolo $\mathrm{n}^{\circ}$ 851/11, sob a responsabilidade de Ana Lúcia Tabet Oller do Nascimento e Natalie Michele de Souza - que envolve a criação e/ou utilização de animais pertencentes ao filo Chordata, subfilo Vertebrata (exceto o homem), para fins de pesquisa científica - está de acordo com os preceitos da Lei n ${ }^{\circ} 11.794$, de 8 de outubro de 2008, do Decreto 6.899, de 15 de julho de 2009 e de normas complementares, bem como está de acordo com os Princípios Éticos na Experimentação Animal adotado pelo Colégio Brasileiro de Experimentação Animal (COBEA), e foi aprovado pela COMISSĀO DE ÉTICA NO USO DE ANIMAIS DO INSTITUTO BUTANTAN (CEUAIB) em reunião de 10/11/2011.

We certify that the research entitled "Immunogenic activity evaluation of two predicted membrane proteins of Leptospira interrogans expressed in Escherichia coli", protocol number 851/11, under the responsibility of Ana Lúcia Tabet Oller do Nascimento and Natalie Michele de Souza - which involves the breeding and/or use of animals belonging to phylum Chordata, subphylum Vertebrata (except human beings), for scientific research - is in agreement with Brazilian laws for use of experimental animals and the Ethical Principles in Animal Research adopted by the Brazilian College of Animal Experimentation, and was approved by the ETHICAL COMMITTEE FOR ANIMAL RESEARCH of BUTANTAN INSTITUTE in the meeting of 10/11/2011.

\begin{tabular}{|c|c|}
\hline Vigência do Projeto: & $\mathbf{N}^{*}$ de animais/espécie \\
\hline $08 / 2011-07 / 2013$ & \\
\hline Laboratório de Centro de & 125 camundongos Balb/c (F) / \\
Biotecnologia & 30 hamsters Golden $(\mathrm{F})$ \\
\cline { 2 - 2 }
\end{tabular}

São Paulo, 11 de novembro de 2011.

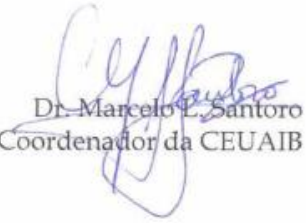


Dedico este trabalho ao meu bom Deus, que colocou pessoas maravilhosas em meu caminho. 


\section{AGRADECIMENTOS}

Á Dra. Ana Lúcia Tabet Oller do Nascimento que confiou o desenvolvimento deste trabalho á mim e me incentivou no decorrer do mesmo.

Á coorientação e auxilio dos pesquisadores Dr. Gustavo Maia de Cerqueira e Dra. Mônica Larruci Vieira.

Aos meus amigos Aline Rodrigues Florêncio Teixeira e Luis Guilherme Virgilio Fernandes pelos conselhos, apoio, discussão do trabalho e companheirismo.

Aos colegas de laboratório e técnicos do laboratório de biotecnologia molecular II e do centro de Biotecnologia do Instituto Butantan.

Ao Dr. Silvio A. Vasconcellos e Zenaide M. de Morais da Faculdade de Medicina Veterinária e Zootecnia da Universidade de São Paulo que nos forneceram as culturas e apoio cientifico em experimentos de desafio.

Á Dra. Eliete C. Romero do Instituto Adolfo Lutz, Divisão de Biologia Medica que nos cedeu amostra de sangue de paciente.

Á professora Dra Toshie Kawano, Alexsander S. Souza e Henrique Krambeck Rofatto do departamento de Parasitologia do Instituto Butantan pelo auxílio no uso do microscópio confocal.

Aos meus familiares em especial meus pais Maria e Messias, avós Joana e Sebastião, irmãos Anne Marcely e Marcel Matheus.

Ao meu "namorado" e irmão em Cristo Izaac S Silva. Agradeço o apoio que foi essencial para o desenvolvimento deste trabalho.

A minha tia Maria Lúcia Anjos Silva que me forçou a estudar, possibilitando a confecção deste trabalho.

As agencias de fomento FAPESP, CNPq e Fundação Butantan 
"Havendo, pois, o SENHOR Deus formado da terra todo o animal do campo, e toda a ave dos céus, os trouxe a Adão, para este ver como lhes chamaria..." (Gênesis 2:19a) Bíblia Sagrada 


\section{RESUMO}

SOUZA, N. M. Avaliação da atividade imunogênica de três proteínas de Leptospira interrogans expressas em Escherichia coli. 2013. 140 f. Dissertação (Mestrado em Biotecnologia) - Instituto de Ciências Biomédicas, Universidade de São Paulo, São Paulo, 2013.

A leptospirose é uma zoonose que causa impacto na saúde publica de países em desenvolvimento. Esta doença é causada por bactérias do gênero Leptospira e é transmitida pela urina de animais infectados. No mundo aproximadamente 500.000 casos são reportados a cada ano com $10 \%$ de taxa de mortalidade. No entanto, os dados podem estar subestimados devido ao difícil diagnóstico da doença. As manifestações clinicas da leptospirose são variadas. Após a infecção, pacientes podem ser assintomáticos ou apresentar quadros clínicos mais severos com falência pulmonar, renal e hepática (síndrome de Weil). Os mecanismos de controle desta doença compreendem medidas de difícil adoção e ineficazes. Vacinas contra leptospirose atualmente são baseadas em células inativadas e possuem desvantagens como toxicidade, curto período de proteção e a impossibilidade de proteção contra sorovares não presentes na preparação. $\mathrm{O}$ sequenciamento de Leptospira interrogans sorovar Copenhageni identificou proteínas hipotéticas de membrana externa que podem ter implicações na patogenicidade da bactéria. Após analise do genoma, os genes LIC11121, LIC11087, LIC11228 e LIC11084 foram escolhidos para caracterização da imunogenicidade de suas respectivas proteínas. As proteínas codificadas pelos genes LIC11087, LIC11228 e LIC11084 foram identificadas na membrana externa de $L$. interrogans por imunofluorescência. Esses genes foram amplificados com o emprego de oligonucleotídeos específicos e clonados no vetor de expressão pAE. A clonagem foi confirmada por sequenciamento dos clones recombinantes. As proteínas foram expressas em Escherichia coli BL21 SI e E. coli BL21 (DE3), e purificadas por cromatografia de afinidade ao metal. Camundongos foram imunizados e produziram anticorpos contra as proteínas recombinantes. Adicionalmente a proteína rLIC11084

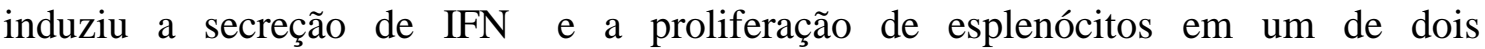
experimentos independentes. Esta proteína induziu imunidade protetora em 58\% dos hamster imunizados frente desafio letal, porém esta sobrevida não foi estatisticamente significante. As proteínas rLIC11087, rLIC11228 e rLIC11084 foram reconhecidas por anticorpos no soro de pacientes na fase convalescente da doença. A proteína rLIC11087 foi reconhecida por anticorpos presentes no soro de hamsters experimentalmente infectados. Estes resultados podem indicar a expressão destas proteínas durante a infecção. As proteínas rLIC11087 e rLIC11228 se ligam a laminina e a fibronectina plasmática. Estas interações podem ser importantes para a adesão da bactéria a componentes de matriz extracelular durante a colonização dos tecidos. rLIC11087, rLIC11228 e rLIC11084 são ligantes de plasminogênio, componente que pode ser convertido a plasmina enzimaticamente ativa. Isto pode ter implicações nos mecanismo de degradação da matriz extracelular pela bactéria e na capacidade da mesma em evadir o sistema imune. A proteína rLIC11087 também interage com C4bp e fibronogenio e pode participar da evasão do sistema imune e inibição do coágulo de fibrina.

Palavras-chave: Leptospirose. Leptospira. Imunogenicidade. Adesinas. Proteína recombinante. 


\begin{abstract}
SOUZA, N. M. Evaluation of immunogenic activity of three proteins of Leptospira interrogans expressed in Escherichia coli. 2013. 140 p. Masters thesis (Biotechnology)- Instituto de Ciências Biomédicas, Universidade de São Paulo, São Paulo, 2013.

Leptospirosis is a zoonosis with great impact in public health of developing countries. The disease is caused by pathogenic bacteria of the genus Leptospira, and is transmitted by urine of infected animals. In the world, 500,000 cases are reported each year with a mortality rate of $10 \%$. However, these data are possibly underestimated due to the difficulties of diagnosis. The symptoms are unspecific, ranging from flu-like symptoms to severe clinical cases with pulmonary, renal and hepatic failure (Weil syndrome). The control of leptospirosis is difficult to implement. Vaccines against leptospirosis are composed by killed whole cells and have many drawbacks, such as low efficacy, the requirement for annual booster immunizations, and the failure to confer cross-protective immunity against different serovars. In the genome sequencing of Leptospira interrogans serovar Copenhageni, putative outer membrane proteins that might be involved in pathogenicity were identified. After genome analysis, based on cellular localization prediction, the genes LIC11121, LIC11087, LIC11228 and LIC11084 were chosen and the immunogenicity of the corresponding proteins was evaluated. Proteins coded by the genes LIC11087, LIC11228 and LIC11084 were probably located in outer membrane of $L$. interrogans, as assessed by immunofluorescence microscopy. These genes were amplified by specific primers and cloned in the expression vector $\mathrm{pAE}$. The correct cloning was checked by DNA sequencing. The proteins were expressed in Escherichia coli BL21 SI and E. coli BL21 (DE3), and were further purified by metal chelating chromatography. Mice were immunized and produced antibodies against recombinant proteins. Moreover, the protein rLIC11084 induced the secretion of IFN $\gamma$ and promoted lymphoproliferation in one of two independent experiments. This protein induced a protective response in 58\% of immunized hamsters against lethal challenge. However, this protection was not statistically significant. The proteins rLIC11087, rLIC11228 and rLIC11084 were recognized by antibodies in confirmed serum samples of patients at the convalescent phase of the disease. In addition, the protein rLIC11087 was detected by antibodies in serum of hamsters experimentally infected. The results may suggest expression of these proteins during infection. The proteins rLIC11087 and rLIC11228 bind laminin and plasma fibronectin. These interactions may be important for adhesion of the bacteria to extracellular matrix components during tissue colonization. rLIC11087, rLIC11228 and rLIC11084 interact with plasminogen and could be converted to the enzymatically active plasmin. This may have implications in mechanism of degradation of extracellular matrix and capacity of evasion of immune system. The protein rLIC11087 also interacts with C4bp and fibrinogen and may have a role in immune evasion and inhibition of fibrin clot formation.
\end{abstract}

Keywords: Leptospirosis. Leptospira. Immunogenicity. Adhesins. Recombinant protein. 


\section{LISTA DE FIGURAS}

Figura 1- Vetores empregados no processo de clonagem dos genes.

Figura 2- Amplificação dos genes em estudo de espécies do gênero Leptospira.

Figura 3- Avaliação da clonagem dos genes no vetor pAE por análise de restrição e sequenciamento.

Figura 4- Análise da expressão das proteínas recombinantes por eletroforese em SDS-PAGE.

Figura 5- Identificação das proteínas recombinantes por imunoblotting com o anticorpo monoclonal anti-6X histidina......

Figura 6- Análise da purificação de rLIC11084 por SDS-PAGE e espectro gerado por análise das proteínas por dicroísmo circular.

Figura 7- Análise da purificação de rLIC11087 por SDS-PAGE e espectro gerado por análise das proteínas por dicroismo circular......

Figura 8- Análise da purificação de rLIC11228 por SDS-PAGE e espectro gerado por análise das proteínas por dicroísmo circular......

Figura 9- SDS-PAGE para análise da purificação de rLIC11121 (37 KDa)..

Figura 10- Produção de anticorpos por camundongos imunizados após segundo reforço.

Figura 11- Proliferação de esplenócitos de animais imunizados in vitro.

Figura 12- Secreção de IFNy por esplenócitos de animais imunizados.

Figura 13- Curva de sobrevivência de animais imunizados com rLIC11084

Figura 14- Reconhecimento das proteínas recombinantes por anticorpos presentes no soro de hamsters infectados

Figura 15- Reconhecimento das proteínas recombinantes por anticorpos presentes no soro de paciente diagnosticados com leptospirose. 
Figura 16- Adesão das proteínas recombinantes á componentes de matriz 78 extracelular.

Figura 17- Curva dose-resposta para análise da ligação das proteínas recombinantes aos seus respectivos ligantes.

Figura 18- Efeito da estrutura das proteínas recombinantes na adesão a componentes de matriz extracelular.

Figura 19- Análise da interação das proteínas recombinantes com proteínas do soro humano.

Figura 20- Curvas dose resposta para análise da interação entre as proteínas recombinantes e componentes do soro.

Figura 21- Análise da interação das proteínas desnaturadas ás proteínas do soro.....

Figura 22- Interferência de ácido aminocapróico na ligação das proteínas ao plasminogênio

Figura 23- Detecção da atividade enzimática da plasmina a partir de plasminogênio ligado as proteínas recombinantes.

Figura 24- Identificação das proteínas nativas na membrana de $L$. interrogans sv. Copenhageni por imunofluorescência. 


\section{LISTA DE TABELAS}

Tabela 1- Caracteristicas dos oligonucleotídeos iniciadores empregados no processo de clonagem.

Tabela 2- Dados obtidos por analises de bioinformática............................ 56

Tabela 3- Massa molecular e ponto isoelétrico (pI) das proteínas codificadas pelos genes selecionados. 


\section{LISTA DE ABREVIATURAS E SIGLAS}

2YT meio de cultura contendo $1 \%$ de extrato de levedura, $1,6 \%$ de peptona e $0,5 \%$ de $\mathrm{NaCl}$

2YT-ON meio de cultura contendo $1 \%$ de extrato de levedura, $1,6 \%$ de peptona e $0,5 \%$ de $\mathrm{NaCl}$

Amp ampicilina $100 \mu \mathrm{g} / \mathrm{mL}$

BSA albumina de soro bovino

CD Dicroísmo circular

CDS Região codificante de proteína (Protein coding sequence)

cDNA DNA complementar

ConA Concanavalina A

Da Dalton

ddNTP 2', 3' dideoxirribonucleotídeo

DNA ácido desoxirribonucleico

dNTP desoxirribonucleotídeo

DO Densidade Ótica

DTT Ditioteitrol

EDTA Ácido etilenodiamino tetracético

ELISA enzyme-linked immunosorbent assay

EMJH meio de cultura Ellinghausen-McCullough-Johnson-Harris

FITC Fluorescein isothiocyanate

IgG Imunoglobulina $G$

IPTG Isopropil- $\beta$-galatosídeo

$\mathrm{Kb} \quad$ kilobase

KDa kilo Dalton

LB meio de cultura Luria Bertani, contendo $0,5 \%$ extrato de levedura, $1 \%$ triptona, $1 \% \mathrm{NaCl}$

LPS lipopolissacarídeo

MAT teste de microaglutinação

$\mathrm{Mb} \quad$ megabase

MS Ministério da Saúde

OPD o-fenilenodiamina

PAGE/SDS eletroforese em gel de poliacrilamida contendo SDS

$\mathrm{pb} \quad$ pares de base

PBS solução fosfato salina, $\mathrm{pH} 7,4$

PBSls tampão PBS contendo menor concentração de sal, $50 \mathrm{mM}$ de $\mathrm{NaCl}$, e acrescido de $5 \mathrm{mM}$ de $\mathrm{MgCl}_{2}$

PBS-T tampão PBS acrescido de Tween-20 na concentração de 0,005\%

PCR Reação de Polimerase em Cadeia

pI ponto isoelétrico

pK Proteinase K

PMSF Fluoreto de fenilmetanosulfonil

RNA ácido ribonucleico

RT transcriptase reversa

SDS Dodecil sulfato de sódio

TA temperatura de anelamento

TAE tris-acetato $40 \mathrm{mM}$, EDTA $1 \mathrm{mM}$

TLR receptores do tipo Toll

uPA ativador de plasminogênio tipo uroquinase 
1 INTRODUÇÃO E REVISÃO DE LITERATURA ........................................... 17

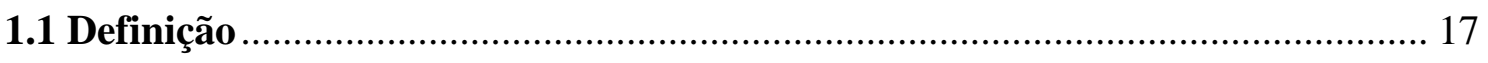

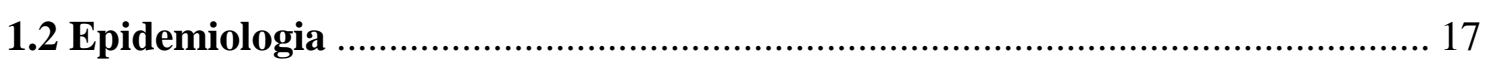

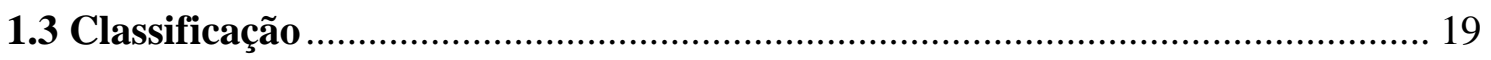

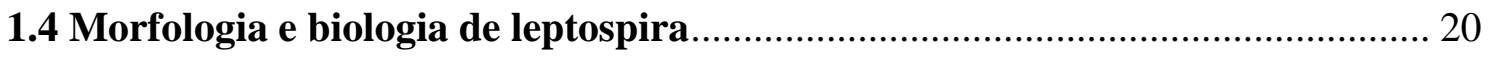

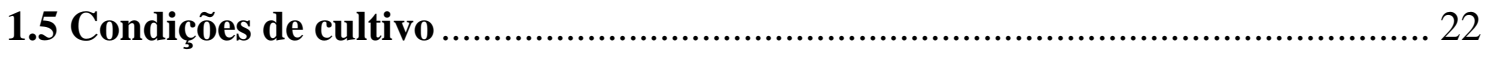

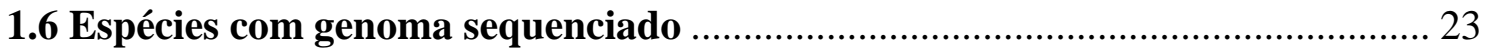

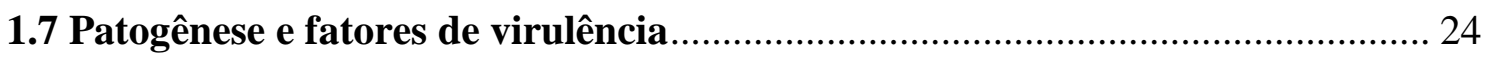

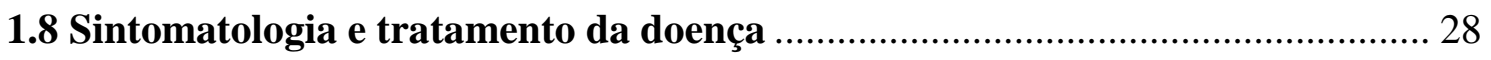

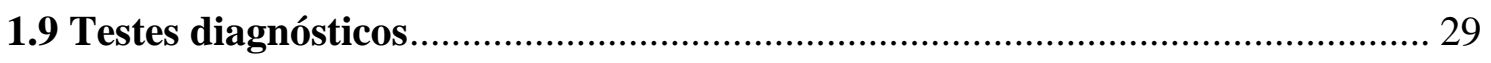

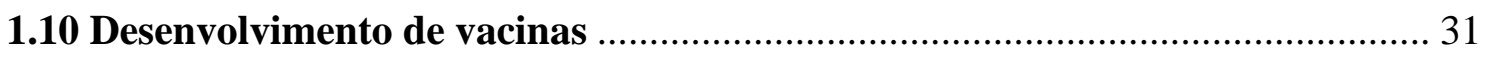

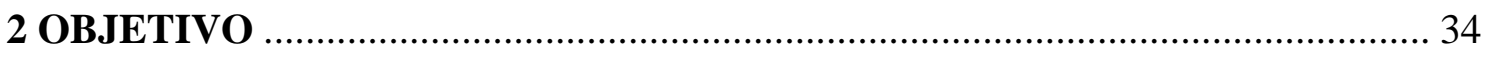

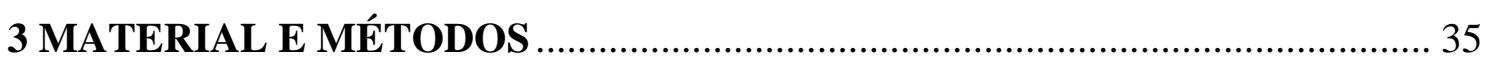

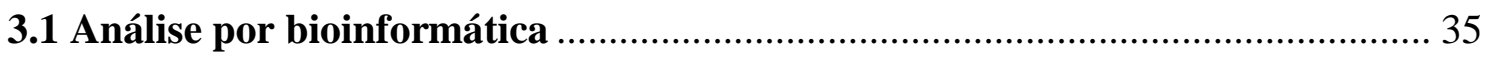

3.2 Linhagens de Leptospira e condições de cultivo ............................................... 35

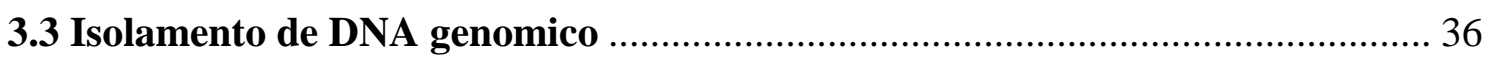

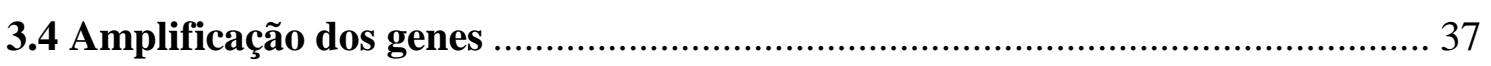

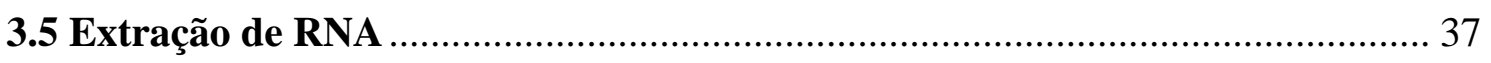

3.6 Síntese de DNA complementar á transcritos de leptospira .............................. 38

3.7 Preparo de extrato proteico total de leptospiras e $E$. coli .................................. 39

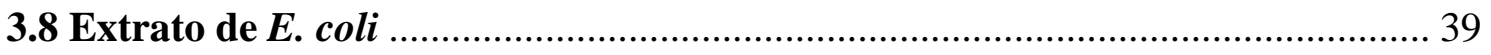

3.9 Western-blotting para análise da expressão de proteínas ................................. 39

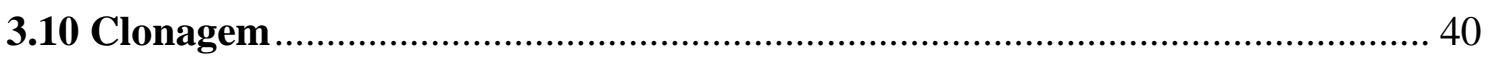

3.11 Expressão das proteínas recombinantes................................................. 43

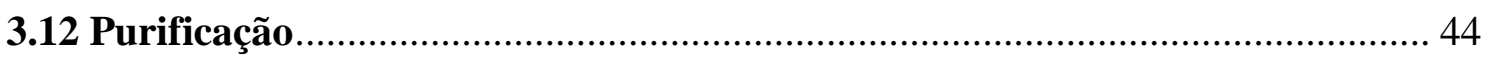

3.13 Espectroscopia circular (CD) das proteínas recombinantes ......................... 45

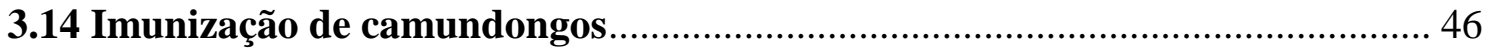

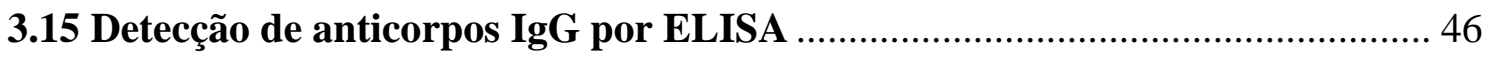

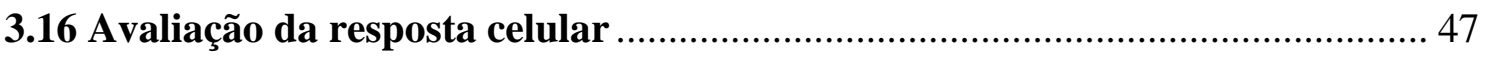

3.17 Interação das proteínas trecombinantes com ECM e componentes do soro .. 48

3.18 Inibição da formação do coágulo de fibrina por rLIC11087 ........................... 50 
3.19 Interferência da interação entre as proteínas recombinantes e plasminogênio pelo ácido aminocapróico 50

3.20 Atividade enzimática de plasmina gerada a partir de plasminogênio ligado ás proteínas recombinante. 50

3.21 Imunofluorescência para análise da localização celular das proteínas ........... 51

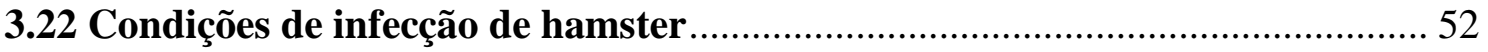

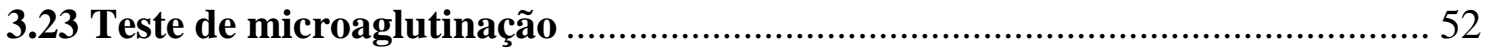

3.24 Detecção de anticorpos no soro de pacientes e animais infectados .................. 52

3.25 Imunização de hamsters e avaliação do perfil protetor de rLIC11084 …........ 53

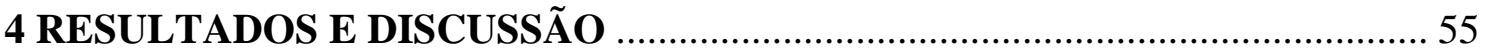

4.1 Características preditas das proteínas que levaram a seleção dos genes .......... 55

4.2 Presença dos genes, seus transcritos e proteínas em espécies do gênero

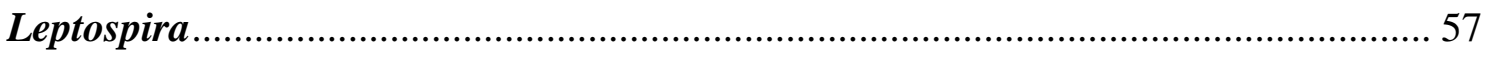

4.3 Clonagem e expressão das proteínas recombinantes......................................... 59

4.4 Purificação das proteínas recombinantes e análise da estrutura secundária ... 65

4.5 Caracterização da resposta imunológica promovida pelas proteínas recombinantes em camundongos

4.6 Avaliação do perfil protetor de hamsters imunizados com rLIC11084 frente desafio letal

4.7 Reatividade das proteínas recombiantes com soro de hamsters infectados e de pacientes diagnosticados com leptospirose. 74

4.8 Interação das proteínas recombinantes com componentes de matriz extracelular.

4.9 Interação das proteínas recombinantes com componentes do soro 81

4.10 Detecção das proteínas nas leptospiras por imunofluorescencia ...................... 86

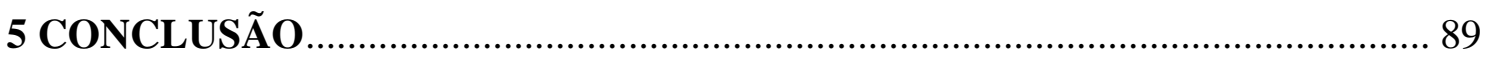

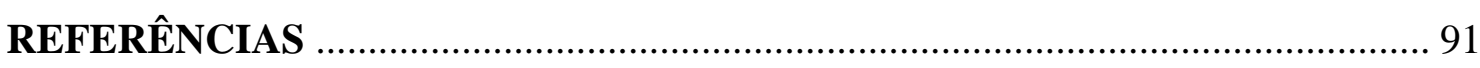

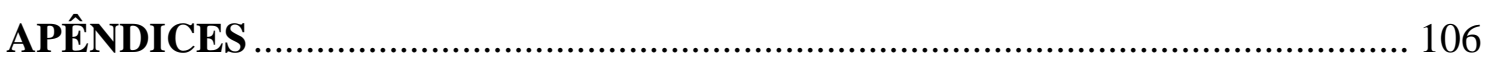

APÊNDICE A- Alinhamento dos aminoácidos das proteínas codificadas pelos genes

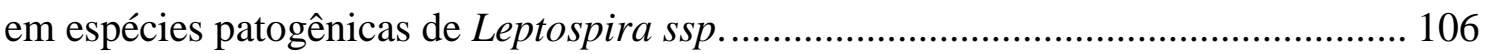

APÊNDICE B- Artigo publicado no período de desenvolvimento do mestrado ......... 113

APÊNDICE C- Artigo publicado no período de desenvolvimento do mestrado ......... 125 


\section{INTRODUÇÃO E REVISÃO DE LITERATURA}

\subsection{Definição}

Leptospirose é uma zoonose com impacto na saúde publica e acarreta prejuízos econômicos na agropecuária. Esta doença é causada por bactérias patogênicas do gênero Leptospira, e é transmitida ao homem principalmente através do contato com a urina de animais infectados. A ocorrência da leptospirose nos centros urbanos está relacionada a inundações que propiciam a disseminação e a persistência do agente causal no ambiente. As manifestações desta doença variam de sintomas semelhantes ao de uma gripe á sintomas com maior gravidade, com taxa de mortalidade variando de 5 á 10\% (McBRIDE et al., 2005; WORLD HEALTH ORGANIZATION, 1999).

A doença foi primeiramente reportada por Adolf Weil em 1886, mas manifestações similares foram observadas anteriormente na china em trabalhadores de plantações de arroz. Em 1907 uma publicação demonstrou à presença de espiroquetas nos túbulos renais de um paciente cuja morte foi reportada como febre amarela e a informação negligenciada por anos. A relação entre leptospirose e o isolamento de espiroquetas ocorreu em 1915 por grupos de pesquisa independentes no Japão e na Alemanha (LEVETT et al., 2001). Atualmente a leptospirose é reconhecida uma zoonose emergente (EVANGELISTA; COBURN, 2010), com alta incidência em países tropicais e em desenvolvimento (PAPPAS et al., 2008).

\subsection{Epidemiologia}

A leptospirose é uma zoonose que afeta humanos em todos os continentes, em regiões urbanas e rurais, em países de clima tropical e de clima temperado (VINETZ, 2001). Possui maior incidência em países de clima tropical e em desenvolvimento, onde sua ocorrência está relacionada principalmente á ocorrência de chuvas sazonais, problemas higiênico-sanitários e a alta população de roedores (BHARTI et al., 2003). Nos países desenvolvidos a incidência da leptospirose está relacionada a esportes aquáticos, eventos recreativos em ambientes contaminados, e mudanças climáticas (MEITES et al., 2004; MORGAN et al., 2002; NARITA et al., 2005; STARK et al., 2009; STERN et al., 2010).

Leptospirose foi formalmente considerada a primeira doença ocupacional em estudos que reconheceram a propensão de mineiros em contraírem a doença. Atualmente tem sido atribuído risco ocupacional á profissões que requerem o contato dos profissionais com 
animais, dentre estas fazendeiros, e profissões que expõe trabalhadores a ambientes contaminados, como agricultores (LEVETT et al., 2001).

No mundo em torno de 500.000 casos são relatados por ano, e a taxa de mortalidade chega a 10\% (WHO, 1999). No entanto, estes dados podem estar subestimados devido á dificuldades na confirmação do diagnóstico da doença, ao fato dos sintomas serem comuns a outras doenças e o difícil diagnóstico de formas menos severas (HARTSKEERL, 2005). Apesar da ausência de dados absolutos, surtos têm sido registrados em países como Nicarágua, Brasil, Índia, Sudeste Asiático, Malásia e Estados Unidos da América, enquanto que pouco é conhecido sobre a incidência de leptospirose no continente africano (PAPPAS et al., 2008).

No Brasil são reportados em média 3.500 casos por ano (BRASIL, 2012). Nos últimos 10 anos a região sudeste é a região que possui maior numero de casos reportados, e São Paulo é o estado com maior incidência da doença desde 1996 (BRASIL, 2012). A incidência de leptospirose em favelas tem sido reconhecida como um fator de risco no Brasil (KO et al., 1999). A doença acarreta custos com hospitalizações e prejuízos econômicos. Em 2007, custos com hospitalizações chegaram á 831,5 mil reais e o prejuízo com salários perdidos foi de 22,9 milhões de reais (SOUZA et al., 2011).

A leptospirose pode acarretar prejuízos para a agropecuária uma vez que o tratamento de animais infectados possui custo elevado e a vacinação destes animais pode ser ineficaz (ALT; ZUERNER; BOLIN, 2001). Animais infectados podem apresentar mastite, infertilidade, abortos, nascimentos prematuros, nascimento de crias debilitadas, nascimento de fetos mortos, perda de peso, menor produção de leite, anemia e síndromes hemorrágicas (FAINE et al., 1999).

Leptospiras colonizam os túbulos renais de animais carreadores. Muitos destes hospedeiros são assintomáticos e contaminam o meio ambiente através da urina. O homem é hospedeiro terminal da doença, e pode se contaminar pelo contato direto com animais infectados ou pelo contato com ambiente contaminado com a urina de animais carreadores (BHARTI et al., 2003; FAINE et al., 1999).

Nos centros urbanos o principal reservatório da bactéria são roedores sinantrópicos (domésticos) das espécies Rattus norvegicus, Rattus rattus e Mus musculus. Porém outros animais, como caninos, suínos, bovinos, eqüinos, ovinos, caprinos e vertebrados pecilotérmicos podem ser transmissores (FAINE et al., 1999; KO et al., 2009; LEVETT, 2001). 
Medidas de controle da doença compreende principalmente o controle de roedores e medidas higiênico sanitárias como a desinfecção de domicílios após as enchentes, a proteção individual durante exposição á áreas alagadas ou enlameadas e o descarte de alimentos que entraram em contato com água de enchentes (BRASIL, 2005). Estas medidas são de difícil implementação e são ineficazes (KO et al., 1999). Alguns países como China e Cuba adotaram a vacinação de humanos para prevenção da doença (GONZÁLES et al., 2005; MARTINEZ et al., 2004; YAN et al., 2003). Porém estas vacinas são baseadas em células mortas e confere proteção de curta duração, não indução de imunidade cruzada com outros sorovares não incluídos na preparação e possívelmente induzem uma resposta autoimune (KOIZUMI; WATANABE, 2005; RATHINAM et al., 1997).

\subsection{Classificação}

O gênero Leptospira pertence á família Leptospiraceae e a ordem Spirochaetales (PASTER et al., 1991). Nesta ordem estão inclusas outras famílias de importância médica como Spirochaetaceae e Brachyspiraceae. Na família Spirochaetaceae estão inclusas espécies causadoras da doença de lyme (Borrelia burgdorferi, B. garinii,e B. afzelii), febre recorrente (B. recurrentis e B. hermsii), sífilis (Treponema pallidum) e peridontite ( $T$. denticola) (LEBECH et al., 2002; SCHRÖDER et al., 2008). Na família Brachyspiraceae estão inclusas as espécies Brachyspira pilosicoli e B. aalborgi, causadoras de espiroquetoses intestinais (TSIGANOU; GEBBERS, 2010).

Tradicionalmente o gênero Leptospira é dividido em espécies saprofíticas, L. biflexa, e patogênicas, L. interrogans (PLANK; DEAN, 2000). As espécies do gênero Leptospira podem ser classificadas em mais de 250 sorovares que são agrupados em 24 sorogrupos (FAINE et al., 1999). A espécie L. biflexa possui mais de 60 sorovars enquanto que a espécie L. interrogans pode ser dividida em mais de 200 sorovares (LEVETT, 2001). Esta classificação é baseada na detecção de anticorpos aglutinantes, antígeno específico, pelo teste de aglutinação microscópica (MAT). Esta variação antigênica é atribuída principalmente a variações na estrutura do carboidrato que compõe o lipopolissacarídeo (ADLER; DE LA PEÑA MOCTEZUMA, 2010).

Apesar de a classificação sorológica ser importante para fins clínicos e epidemiológicos, a taxonomia da família Leptospiraceae passou a ser baseada na classificação genotípica após demonstrações da heterogeneidade genética de espécies agrupadas num 
mesmo sorovar (BRENNER et al., 1999). Atualmente espécies patogênicas e saprofíticas são categorizadas nas genomospecies 1,3,4 e 5 (ADLER; DE LA PEÑA MOCTEZUMA, 2010).

Assim a família Leptospiraceae passou a compreender 13 espécies patogênicas $L$. alexanderi, L. alstonii (genomospecies 1), L. borgpetersenii, L. inadai, L. interrogans, L. fainei, L. kirschneri, L. licerasiae, L. noguchi, L. santarosai, L. terpstrae (genomospecie 3), L. weilii, L. wolffii; e as espécies saprofíticas L. biflexa, L. meyeri, L. yanagawae (genomospecies 5), L. kmetyi, L. vanthielii (genomospecies 4) e L. wolbachii (ADLER; DE LA PEÑA MOCTEZUMA, 2010).

SMYTHE e colaboradores 2012 sugere ainda a classificação das genomoespecies 1, genomospecies 3, genomospecies 4 e genomospecies 5 respectivamente como Leptospira alstonii sp. nov., Leptospira vanthielii sp. nov., Leptospira terpstrae sp. nov., Leptospira yanagawae sp. nov.

Análise filogenética dos genes que codificam para a subunidade $16 \mathrm{~S}$ demonstra que as espécies do gênero Leptospira podem ser agrupadas em três clados, patogênico, saprofítico e intermediário (LEVETT et al., 2006; PEROLAT et al., 1998). Assim, foram categorizados no subgrupo das espécies saprófitas as espécies L. biflexa, L. wolbachii, L. kmetyi, L. meyeri, L. vanthielii, L. terpstrae e $L$. yanagawae; no subgrupo patogênico as espécies $L$. interrogans, $L$. kirschneri, L. borgpetersenii, L. santarosai, L. noguchii, L. weilii, L. alexanderi e L. alstoni; e no subgrupo intermediário as espécies L. inadai, L. broomii, L. fainei, L. wolffii e L. licerasiae (KO et al., 2009).

\subsection{Morfologia e biologia de leptospira}

Leptospiras são finas, com tamanho de aproximadamente $0,25 \mathrm{~m}$ por 6-25 m, e helicoidais. Possuem caracteristicamente as extremidades terminadas em gancho e por isso, quando primeiramente visualizadas, foram nomeadas Spirochaeta interrogans (LEVETT, 2001). Apesar de classificadas como bactérias gram-negativas a parede celular desta bactéria possui características atípicas e comuns a de bactérias gram-positivas. A parede celular é composta por uma membrana interna, peptídeoglicano, dois flagelos periplasmáticos e membrana externa. $\mathrm{O}$ fato de o peptídeoglicano estar ancorado na membrana interna é comum á bactérias gram-positivas, enquanto que a presença de duas membranas na parede celular e a presença de lipopolissacarídeo (LPS) na membrana externa são características comuns a bactérias gram-negativas (HOLT, 1978). 
Diferente de B.burgdorferi e similarmente á $T$. pallidum a morfologia heliptíca de leptospiras está relacionada ao peptídeoglicano. A composição química do peptídeoglicano é similar a de bactérias gram-negativas apesar dos constituintes desta macromolécula ser peculiares (SLAMTI et al., 2011).

Os dois endoflagelos periplasmáticos conferem motilidade ás células. Em espiroquetas as proteínas FlaA e FlaB constituem respectivamente a bainha e o core flagelar. Mutações no gene $f l a B$, que codifica para uma proteína flagelar, na espécie saprófita L. biflexa resulta na ausência do endoflagelo e na perda da movimentação bacteriana (PICARDEAU et al., 2001; WOLGEMUTH et al., 2006). Apesar disso mutações no gene flaA demonstraram que as proteínas codificadas por estes genes não afetam a formação da bainha e geração do flagelo mas afetam o movimento transacional, morfologia celular e virulência da bactéria (LAMBERT et al., 2012).

Há três tipos de movimentação possíveis: rotação sobre um eixo central, movimento progressivo (reto) e movimentação circular (BHARTI et al., 2003). O movimento rotacional pode estar relacionado á patogênese. Mutações no gene fliY em L. interrogans sv. Lai resulta na perda do movimento rotacional e no aumento da taxa de sobrevivência do hospedeiro suscetível porquinho da índia, guinea pigs (LIAO et al., 2009).

Leptospiras apresentam LPS diferente de outras espiroquetas como T. pallidum e $B$. burgdorferi. O LPS destas bactérias possui composição similar á de outras bactérias gramnegativas e é menos tóxico (LEVETT, 2001). O lipídeo A é um ácido graxo incomum e possui um resíduo fosfatado e metilado (QUE-GEWIRTH et al., 2004). Possivelmente devido a isso macrófagos humanos são incapazes de reconhecer o lipídeo A de leptospira (NAHORI et al., 2005).

Essa composição atípica do lipídeo A pode ser o fator determinante na susceptibilidade de humanos a infecção. Células do sistema imune inato de humanos reconhecem LPS via TLR-2 ao invés de TLR-4, situação comum á outras bactérias (WERTS et al., 2001). Camundongos são animais resistentes á infecção e desencadeiam fraca resposta inflamatória após longos períodos de colonização renal por leptospiras. Esses animais são capazes de reconhecer o LPS de leptospira tanto pelo por TLR-2 quanto por TLR-4. Foi constatado que mutantes nestes dois receptores tornam camundongos suscetíveis á infecção (CHASSIN et al., 2009).

O antígeno $\mathrm{O}$ de leptospiras é composto principalmente por raminose, cuja síntese é coordenada pelos genes do locus rfb. A posição 3' deste locus é conservada enquanto que a 
posição 5' é diferente entre sorovares distintos (DE LA PENA-MOCTEZUMA et al., 1999). O LPS é importante para estabilidade da membrana de enterobactérias e pode ser essencial tanto para a viabilidade de leptospiras e como para a letalidade delas. Isto pode ser experimentalmente visualizado em mutações de genes presentes no locus rfb (MURRAY et al., 2009, 2010).

O LPS é o determinante antigênico de leptospiras. Numa infecção por leptospiras o sistema imune direciona a produção de anticorpos principalmente contra o LPS (DE LA PENA-MOCTEZUMA et al., 1999; FAINE et al., 1999). A imunização passiva com anticorpos monoclonais contra o LPS pode conferir proteção no modelo de infecção porquinho da índia (JOST et al., 1986).

Além do LPS proteínas de membrana externa são importantes para compreensão da biologia de leptospiras. Estas proteínas podem mediar o transporte de substâncias e cumprir papéis funcionais importantes na atuação de mecanismos de patogênese, papéis enzimáticos e facilitar a colonização renal. Adicionalmente estas proteínas podem ter papel na imunogenicidade durante a infecção (CULLEN et al., 2005). As proteínas com maior abundancia na superfície de L. interrogans são LipL32 (ou Hap1), OmpL1, LipL21 e Lip41 (CULLEN et al., 2005; HAAKE et al., 2000). A proteína com maior número de cópias por célula é a LipL32, com mais de 38.000 cópias por célula (MALMSTRÖM et al., 2009).

As proteínas de membrana externa de espiroquetas possuem peptídeo sinal na porção $\mathrm{N}$ terminal. Essa sequencia é clivada e então a proteínas é translocada através da membrana. A região carboxiterminal do peptídeo sinal (lipobox) difere das demais bactérias (SETUBAL et al., 2006). Proteínas de membrana de espiroquetas podem ser exportadas por uma via própria, ainda não caracterizada (CULLEN et al., 2005).

Essas proteínas podem se associar a membrana externa de três diferentes maneiras, através de uma porção lipídica (lipoproteínas), através de porções proteicas transmembrana e por porções que não transpassam a membrana (proteínas de membrana externa periférica) (CULLEN et al., 2005).

\subsection{Condições de cultivo}

Leptospiras são aeróbicas obrigatórias e possuem crescimento ótimo entre 28 e $30^{\circ} \mathrm{C}$. São catalase e oxidase positiva e crescem em meio simples enriquecido com vitaminas B2 e B12, fatores de crescimento, ácidos graxos de cadeia longa e sais de amônia. Ácidos graxos 
de cadeia longa são as fontes de carbono e são metabolizados por $\beta$-oxidação. $O$ crescimento de leptospiras é vagaroso e o tempo de geração é de aproximadamente 20 h (LEVETT, 2001). O meio comumente empregado para o cultivo destas espiroquetas é o EMJH (EllinghausenMcCullough/Johnson-Harris). Este meio é composto principalmente por ácido oleico, albumina de soro bovino e polisorbato (ELLINGHAUSEN; McCULLOUGH, 1965; JOHNSON; HARRIS, 1967).

Algumas espécies patogênicas, como L. interrogans podem sobreviver em ambientes carentes de nutrientes, com concentrações salinas, $\mathrm{pH}$ e viscosidade críticas, como solo e água por longos períodos (TRUEBA et al., 2004). A espécie L. borgpetersenii não possui genes que permite a sobrevivência no ambiente. Assim a transmissão desta bactéria ocorre pelo contato com hospedeiro contaminado (BULACH et al., 2006). A formação de biofilme é um mecanismo propostamente empregado para sobrevivência da leptospira em diferentes nichos ambientais (RISTOW et al., 2008).

\subsection{Espécies com genoma sequenciado}

A disponibilidade de sequencias genomicas tem facilitado á identificação de antígenos vacinais promissores, a compreensão da biologia de microrganismos e a identificação de proteínas associadas a virulência de leptospiras.

Atualmente estão disponíveis as sequencias genomicas de três espécies patogênicas, uma espécie saprófita e uma espécie intermediária. As espécies patogênicas com genoma sequenciado são L. interrogans, L. borgpetersenii e L. santarosai. Os dois sorovares sequenciados de L. interrogans são sorovar Copenhageni linhagem Fiocruz L1-130 e sorovar Lai linhagens 56601 e IPAV (NASCIMENTO et al., 2004a, b; REN et al., 2003; ZHONG et al., 2011). As linhagens de L. borgpetersenii sorovar Hadjo-bovis sequenciadas são L550 e JB197 (BULACH et al., 2006). A sequencia genomica das linhagens Ames e Paris da espécie saprófita L. biflexa sorovar Patoc 1 estão também disponíveis (PICARDEAU et al., 2008).

Em 2012, foram disponibilizadas as sequencias da espécie patogênica L. santarosai sorovar Shermani e da espécie intermediária L. licerasiae linhagens VAR010 e MMD0835 (CHOU et al., 2012; RICALDI et al., 2012). A análise do genoma de L. licerasiae linhagens VAR010 e MMD0835 mostrou que esta espécie intermediária está mais relacionada a espécies patogênicas do que á espécies saprófitas. 
A análise comparativa das sequencia de genomas disponíveis indica que há 2052 genes comuns entre espécies patogênicas e não patogênicas e 900 genes encontrados apenas em espécies patogênicas, L. interrogans e L. borgpetersenii (CHOU et al., 2012).

O genoma total de leptospiras varia entre 4,7 Mbp e 3,9 Mbp. Leptospiras patogênicas apresentam dois cromossomos circulares enquanto que a espécie L. biflexa que possui ainda um terceiro replicon circular, p74 (PICARDEAU et al., 2008). Algumas espécies apresentam prófagos. L. biflexa possui um prófago (LE1) e L. licerasiae possui dois prófagos, um que possui homologia com LE1 e outro homólogo a uma região encontrada no genoma dos sorovares sequenciados de L. interrogans (RICALDI et al., 2012).

\subsection{Patogênese e fatores de virulência}

Os mecanismos de infecção, invasão e persistência da colonização, relacionados a interações entre leptospira e hospedeiros, ainda não são elucidados. A análise das sequencias genomicas disponíveis sugere que muitas proteínas podem estar envolvidas nestas interações. Há 452 genes comuns entre espécies patogênicas e intermediárias e 315 genes exclusivos das espécies patogênicas (RICALDI et al., 2012).

O sequenciamento genomico de L. interrogans $s v$. Copenhageni possibilitou a identificação de mais de 263 genes que codificam para prováveis proteínas expostas na superfície. Muitas destas proteínas, á saber 250, são proteínas hipotéticas de membrana e podem estar envolvidas em mecanismos de patogenicidade (NASCIMENTO et al., 2004a).

No sequenciamento do genoma também foram identificados genes que participam de mecanismos de patogenicidade elucidados em outras bactérias como adesinas afimbriais, esfingomielinase, fosfolipase D, colagenases, metaloprotease e termolisinas (NASCIMENTO et al., 2004a).

Algumas estratégias de mutagenese tem possibilitado a investigação de genes envolvidos na patogênese. Por meio da caracterização fenotípica de mutantes alguns fatores de virulência foram descobertos. Nas espécies patogênicas, mutantes têm sido gerados por mutagenese específica, através de recombinação homóloga, e pela inserção do elemento transponível Himarl mariner (CRODA et al., 2008; LAMBERT et al., 2012; LIAO et al., 2009; MURRAY et al., 2009d; RISTOW et al., 2007).

A motilidade pode ser um fator essencial para virulência bacteriana. Como descrito anteriormente a inativação de genes que codificam para proteínas FliY e FlaA afetam a 
motilidade e podem atenuar a virulência de leptospiras (LAMBERT et al., 2010; LIAO et al., 2009). Outros fatores de virulência descritos até o presente momento compreendem o LPS e as proteínas Loa22, HemO, ClpB e InvA também identificados pela geração de mutantes (LOURDAULT et al., 2011; LUO et al., 2011; MURRAY et al., 2008, 2009b; 2010; RISTOW et al., 2007).

O processo de adesão é provavelmente o primeiro passo necessário a patogênese e infecção. Semelhante a outros patógenos microbianos, leptospiras interagem com matriz extracelular e com linhagens celulares, células endoteliais e células epiteliais cultivadas in vitro (BREINER et al., 2009; CHIRATHAWORN et al., 2007; ITO; YANAGAWA, 1987). Foi demonstrado que leptospiras podem interagir com componentes de matriz extracelular, á saber com, laminina, colágeno tipo I, colágeno tipo IV, fibronectina celular e fibronectina plasmática (BARBOSA et al., 2006).

Diferentes proteínas de superfície de leptospiras podem estar envolvidas no processo de adesão. Estas proteínas podem interagir diretamente com os componentes, e ou indiretamente, induzindo a expressão dos receptores de células eucarióticas ICAM-1 e Eselectina em células endoteliais (ATZINGEN et al., 2009; GOMEZ et al., 2008; VIEIRA et al., 2007).

Duas famílias de adesinas afimbriais de L. interrogans foram identificadas no genoma, a saber, a família Lig e a família de proteínas semelhantes a integrina $\alpha$, codificadas pelos genes LIC12259, LIC10021 e LIC13101 (NASCIMENTO et al., 2004a).

As proteínas da família Lig possuem domínios Big (do inglês "bacterial immunoglobulin-like”). Esse domínio é encontrado em adesinas de outras bactérias como intimina de E. coli e invasina de Yersinia pseudotuberculosis (HAMBURGER et al., 1999; LUO et al., 2000).

Foi constatado que estas proteínas podem interagir com componentes de matriz extracelular. Essas proteínas interagem com elastina, tropoelastina, colágeno tipo I e tipo IV, laminina e fibronectina (CHOY et al., 2007; LIN et al., 2008, 2009a, b; LIN; CHANG, 2007, 2008). Adicionalmente a expressão delas pela espécie saprófita, L. biflexa, conferiu a capacidade de adesão a células em cultura e a fibronectina (FIGUEIRA et al., 2011).

A adesão a componentes de matriz extracelular foi constatado experimentalmente em muitas proteínas. A caracterização de proteínas com localização predita na membrana externa levaou a identificação de muitas proteínas com função de adesina, entre elas uma proteína de $36 \mathrm{KDa}$ que interage com fibronectina, OmpL37, proteínas da familia Len, Lsa63 
(LIC10314), Lsa21 (LIC10368), Lsa27 (LIC12895), LipL32/Hap-1 (LIC11352), Lsa24 (LIC12906), LipL53 (LIC12099), Lp95 (LIC12690), Lp30 (LIC12880 ), Lsa66 (LIC10258), rLIC12238, Lsa20 (LIC11469), Lsa33 (LIC11834), Lsa25 (LIC12253), OmpL1 (LIC10973), Lsa23 (LIC11360), Lsa36 (LIC11975) e Lsa26 (LIC11009) (ATZINGEN et al., 2008, 2009; BARBOSA et al., 2006; DOMINGOS et al., 2012; FERNANDES et al., 2012; HAUK et al., 2008; HOKE et al., 2008; LONGHI et al., 2009; MENDES et al.,, 2011; MERIEN et al., 2000; OLIVEIRA et al., 2010; OLIVEIRA et al., 2011; PINNE et al., 2010; SIQUEIRA et al., em fase de submissão; STEVENSON et al., 2007; VIEIRA et al., 2010a). Inclusive a proteína TlyC, uma predita esfingomielinase bem caracterizada em outras bactérias, foi possível atribuir capacidade de interação com laminina, colágeno tipo IV e fibronectina (CARVALHO et al., 2009).

Esta redundancia funcional pode ser uma explicação para a virulência de mutantes com inativação dos genes lipL32e ligB, que expressam proteínas abundantes de superficie e com função de adesina (CRODA et al., 2008; MURRAY et al., 2009c).

A atividade proteolítica é importante na penetração de micro-organismos patogênicos durante a infecção (LÄHTEENMÄKI et al., 2001). Leptospiras podem adquirir atividade proteolítica pela interação com plasminogênio e posterior conversão deste em plasmina ativa. Essa interação pode auxiliar na degradação de componentes de matriz extracelular, possibilitando assim a penetração no tecido do hospedeiro (VIEIRA et al., 2009).

A captação de plasminogênio na superfície de leptospiras ocorre pela ligação deste á proteínas de membrana externa. Resíduos de lisina das proteínas interagem com domínios Kringle do plasminogênio (LÄHTEENMÄKI et al., 2001). Diferentes receptores de plasminogênio tem sido identificados, á saber LenA/LfhA/Lsa24, LipL32, rLIC12730, rLIC10494, Lp29, Lp49, LipL40, MPL36, rLIC12238, Lp30, rLIC10258, Lsa20, Lsa33 e OmpL1 (DOMINGOS et al., 2012; FERNANDES et al., 2012; MENDES et al., 2011; OLIVEIRA et al., 2011; VERMA et al., 2010b; VIEIRA et al., 2010b).

A atividade proteolítica de leptospiras pela interação com plasminogênio pode contribuir na evasão do sistema imune. Isso foi evidenciado pela diminuição de $\operatorname{IgG}$ e de C3b na superfície de leptospiras após tratamento com plasminogênio e seu ativador, uPA (VIEIRA et al., 2011).

Fibrinogênio é uma proteína plasmática envolvida na cascata de coagulação sanguínea e na agregação de plaquetas. Bactérias do gênero Staphylocococus podem interagir com o fibrinogênio através das proteínas ClfA, de S. aureus, e SdrG, de S. epidermidis. Por meio 
desta interação, essas proteínas podem inibir a formação do coágulo de fibrina e a agregação plaquetária (DAVIS et al., 2001; HAWIGER et al., 1982). As proteínas de leptospira LigA e LigB interagem com fibrinogênio (CHOY et al., 2007). A proteína LigB inibir a formação do coágulo de fibrina interagindo com o fibrinogênio. Este mecanismo pode auxiliar na disseminação da bactéria via corrente sanguínea (CHOY et al., 2011).

Além da evasão do sistema imune pela interação com plasminogênio leptospiras podem interagir com proteínas reguladoras do sistema complemento, como fator $\mathrm{H}$ e C4bp, e escapar de células de defesa tendo uma fase intracelular (VIEIRA et al., 2011). A persistência da infecção de leptospira em mamíferos pode estar relacionada a capacidade delas de resistir as ações do sistema complemento (CHARON et al., 1975). O primeiro mecanismo da resistência ao soro foi dado com a constatação da interação delas com o fator H e a FHR-1 $\alpha$ e FHR-1 $\beta$ (MERI et al., 2005). Proteínas de leptospira que se interagem com C4bp e fator $\mathrm{H}$ têm sido identificadas (BARBOSA et al., 2010; CASTIBLANCO-VALENCIA et al., 2012, CHOY, 2012; DOMINGOS et al., 2012; STEVENSON et al., 2007; VERMA et al., 2006). Essas interações podem explicar a resistência de leptospiras ao soro e ao sistema complemento.

Para atingir os tecidos, leptospiras podem atravessar junções intercelulares e a capacidade destas bactérias em entrar nas células do hospedeiro também tem sido constatada (HAAKE; LOVETT, 1994; LIU et al., 2007; MERIEN et al., 1997). O processo como leptospiras entram nas células do hospedeiro ainda não foi esclarecido. Leptospiras têm sido observadas no citoplasma e em compartimentos fagossomais de diferentes tipos celulares (BAROCCHI et al., 2002; LI et al., 2010; LIU et al., 2007; THOMAS; HIGBIE, 1990). Esta fase intracelular pode ser um mecanismo de translocação para tecidos alvo e um mecanismo de evasão sistema imune.

A persistência da colonização renal pode ser atribuída a diferentes fatores, como a regulação da expressão de proteínas e a formação de biofilme (MONAHAN et al., 2009; RISTOW et al., 2008).

A infecção por leptospiras induzir de processos patológicos por mecanismos autoimunes, como a indução de apoptose, a secreção de anticorpos auto-reativos, e a indução da secreção de citocinas pró- infamatórias (DE FOST et al., 2003; DIAMENT et al., 2002; KLIMPEL et al., 2003; TAJIKI; SALOMÃO, 1996). 
O envolvimento entre apoptose e patogênese da doença é desconhecido. Porém evidencias demonstram que leptospiras podem induzir a apoptose em macrófagos e hepatocitos (ISOGAI et al., 1998; MERIEN et al., 1997, 1998).

Leptospiras podem induzir a secreção de auto-anticorpos, direcionados contra fosfolípides e conhecidos como anti-cardiolipina (aCL) e contra proteínas oculares (RUGMAN et al., 1991; VERMA et al., 2010a). Outros processos patológicos relacionados a secreção de anticorpos são a uveite e a síndrome hemorrágica pulmonar (NALLY et al., 2004; VERMA et al., 2008).

\subsection{Sintomatologia e tratamento da doença}

A infecção por leptospiras pode desencadear diferentes manifestações clinicas. Humanos apresentam desde quadros subclínicos até quadros com elevada gravidade. As manifestações clínicas e a severidade da doença dependem de fatores como a linhagem ou sorovar infectante, forma da infecção (como por exemplo, tamanho de feridas na pele e tempo de exposição a ambientes contaminados) e susceptibilidade do individuo, como por exemplo, a idade, estado imune e características genéticas, como humanos portadores do antígeno leucocitário humano HLA-DQ6 (EVANGELISTA; COBURN, 2010; KO et al., 2009; LINGAPPA et al., 2004).

Os sintomas aparecem após um período de incubação que varia entre 5 e 14 dias. O curso da doença pode ser dividido em duas fases distintas. A fase aguda ou septicêmica ocorre na primeira semana da doença, e a fase imune é caracterizada pela excreção de leptospiras na urina e pela produção de anticorpos (LEVETT, 2001).

Cerca de $90 \%$ dos pacientes apresentam sintomas de baixa gravidade que podem ser classificados como leptospirose anictérica (PLANK; DEAN, 2000). Trabalhos reportam que a maioria dos pacientes apresentam febre, dor de cabeça, mialgia, vomito e náuseas, sintomas comuns a muitas doenças febris e tropicais como influenza, malária, vírus da imunodeficiência humana, dengue e febre tifoide. Isto inviabiliza o diagnóstico baseado na sintomatologia da doença e dificulta o tratamento adequado, o que leva ao agravamento dos sintomas (LEVETT, 2001).

Leptospirose ictérica é a forma mais severa da doença e é caracterizada pelos altos níveis de bilirrubina no soro. Esta forma acomete de $5 \%$ á $10 \%$ dos pacientes com leptospirose e pode ser resultado do curso da doença (LEVETT, 2001). Pacientes podem 
apresentar falência renal aguda (16 á 40\% dos casos com leptospirose), trombocitopenia e problemas pulmonares como a síndrome hemorrágica pulmonar, que leva 50\% dos casos á óbito (KOBAYASHI, 2005). A síndrome de Weil é uma das formas mais severas da doença e é caracterizada por um quadro ictérico, falência renal e sangramentos (KO et al., 2009).

Outras complicações relacionadas á doença incluem aborto, uveite, miocardite e sintomas raros como, acidentes cerebrovasculares, rabdomiólise, púrpura trombocitopênica trombótica (PTT), colecistite aguda acalculosa (CAA), eritema nodoso, estenose aórtica, síndrome de Kawasaki, artrite reativa, epididimite, paralisia de nervos, hipogonadismo masculino e a síndrome de Guillain-Barré (LEVETT, 2001).

O uso de antibióticos é eficiente no tratamento da leptospirose. A recomendação do antibiótico, assim como a dosagem apropriada, é baseada na severidade da doença. Nas formas mais brandas da doença é recomendado o tratamento com doxiciclina, amoxicilina e ampicilina ao passo que para as formas mais severas é recomendado o tratamento com penicilina G (BHARTI et al., 2003). Nos casos mais severos é necessário o apoio hospitalar. A realização de diálise e tratamento de pacientes na unidade de terapia intensiva pode ser necessário, o que acarreta em custos elevados para o sistema de saúde pública (FAINE et al., 1999; LEVETT, 2001; SOUZA et al., 2011).

\subsection{Testes diagnósticos}

O diagnóstico da leptospirose nos estágios iniciais é essencial para o inicio do tratamento adequado, podendo evitar o agravamento dos sintomas. No entanto, os métodos comumente empregados são ineficientes no diagnóstico da doença na fase aguda e compreendem principalmente a análise sorológica e o isolamento de leptospiras em cultura (TOYOKAWA; OHNISHI; KOIZUMI, 2011). Além disso, a inespecificidade dos sintomas dificulta o diagnóstico baseado na investigação dos sintomas. Assim mesmo em regiões onde é comum a ocorrência de leptospirose poucos casos são identificados desde a análise clinica inicial (SASAKI et al., 1993).

Algumas alterações bioquímicas nos pacientes com leptospirose podem sugerir o diagnostico. Porém a confirmação do diágnóstico é realizada por sorologia. Os testes sorológicos empregados compreendem o teste de aglutinação microscópica (MAT), o teste de aglutinação cruzada (“cross agglutinin absorption test” CAAT), ELISA com a imobilização de um antígeno não caracterizado de $35 \mathrm{KDa}$ e um teste rápido para detecção de anticorpos contra a proteína LigA (NABITY et al., 2012; TOYOKAWA; OHNISHI; KOIZUMI, 2011). 
O método mais recomendado para o diagnóstico de leptospirose é o MAT. Neste teste amostras de soro de pacientes são misturados a leptospiras. As amostras são incubadas de 2 á 4 horas á temperatura ambiente e então examinadas quanto a aglutinação por microscopia de campo escuro. A amostra é considerada positiva quando há aglutinação maior que $50 \%$ em relação á reação controle (TOYOKAWA; OHNISHI; KOIZUMI, 2011).

Este teste tem por desvantagem a baixa sensibilidade na fase aguda da doença e a necessidade da manutenção de espécies em cultivo. A organização mundial da saúde recomenda o emprego de 19 sorovars de 16 sorogrupos o que requer a manutenção de culturas em laboratórios de referencia (WHO, 2003). Adicionalmente em regiões endêmicas o MAT pode ter baixa acurácia devido a existência de anticorpos contra leptospira de infecções prévias (IgM) e pela reação cruzada com outros agentes infecciosos (BLACKSELL et al., 2006; MYINT et al., 2007).

Anticorpos contra antígenos proteicos podem ser detectados em amostras de soro de pacientes diagnosticados com leptospirose. Assim o emprego de proteínas conservadas entre diferentes sorovares pode ser promissor em aplicações diagnósticas. Estes antígenos podem conferir alta sensibilidade e especificidade ao teste devido a alta concentração de antígenos utilizado e a ausência de motivos inespecíficos, presentes com o emprego da célula total (TOYOKAWA; OHNISHI; KOIZUMI, 2011).

Um teste rápido para o diagnóstico com a proteína LigA foi desenvolvido, DPP (Dual Path Platform) (Chembio Diagnostic Systems, Medford, New York, USA). Entretanto este teste apresenta baixa sensibilidade para o diagnóstico de pacientes com a forma branda da leptospirose na fase aguda da doença, 64\% de sensibilidade (NABITY et al., 2012).

O método diagnóstico mais eficiente para a fase aguda da doença é o PCR. Entretanto o custo e a tecnologia necessária para realização do PCR invibializa sua aplicação em laboratórios de países em desenvolvimento. Iniciadores específicos para os genes secY, rrs, flaB, rrl e LA3521 tem sido empregados para a detecção de DNA em amostras de sangue, urina, LCR, humor aquoso e de diferentes tecidos (BROWN et al., 1995; FONSECA et al., 2006 a,b; KOIZUMI et al., 2003; KOSITANONT et al., 2007; MERIEN et al., 1995). A WHO recomenda o emprego de iniciadores para os genes secY (G1 e G2) e flaB (B64I e B64II) em aplicações diagnósticas (WHO, 2003). Adicionalmente a detecção de DNA por PCR, o PCR em tempo real tem aumentado a confiabilidade dos resultados pela discriminação entre a amplificação de um gene em especifico e gene oriundo de contaminação (AHMED et al., 2009; LEVETT et al., 2005; LOURDAULT et al., 2009; MERIEN et al., 2005; 
PALANIAPPAN et al., 2005; SLACK et al., 2006, 2007; SMYTHE et al., 2002; STODDARD et al., 2009).

Diante da inviabilidade do diagnóstico por PCR em países em desenvolvimento, o método de amplificação mediada por ciclo isotérmico (loop-mediated isothermal amplification -LAMP) foi desenvolvido (MORI; NOTOMI, 2009). Esta técnica tem possibilitado a amplificação de genes específicos de leptospiras patogênicas em amostras clinicas (KOIZUMI et al., 2012; LIN et al., 2009c; SUWANCHAROEN et al., 2012). No entanto, a baixa sensibilidade e especificidade do método mostra que ele ainda é inapropriado para o diagnóstico de leptospirose (SONTHAYANON et al., 2011).

\subsection{Desenvolvimento de vacinas}

Como anteriormente abordado as vacinas disponíveis contra leptospirose são ineficazes. Essas vacinas são capazes de conferir resposta protetora através da indução da secreção de anticorpos contra lipopolissacarídeos (LPS) de leptospira (DE LA PENAMOCTEZUMA et al., 1999). Atualmente os principais alvos de pesquisa para compor uma vacina são proteínas da membrana externa conservadas entre cepas patogênicas e com capacidade de induzir longa resposta protetora (KOIZUMI; WATANABE, 2005).

As primeiras proteínas recombinantes testadas quanto seu perfil protetor foram OmpL1 e LipL41. Nesta abordagem estas proteínas foram expressas associadas a membrana externa de E. coli e coadministradas. Neste experimento foi possível proteção significativa em um de três experimentos independentes, e a taxa de sobrevivência foi de $100 \%$ em hamsters (HAAKE et al., 1999).

Outra estratégia para especulação da imunogenicidade de OmpL1 ocorreu pela sua expressão em células de mamíferos, infectadas por adenovírus recombinante. Porém esta estratégia falhou em conferir proteção no modelo de infecção gerbil (BRANGER et al., 2001).

A proteína mais abundante da superfície de leptospira, LipL32, é incapaz de conferir imunidade protetiva (BRANGER et al., 2001; LUCAS et al., 2011). Diferentes estratégias visando o aumento da imunoproteção têm sido desenvolvidas, entretanto os resultados não são promissores para um candidato vacinal em potencial (KO et al., 2009).

A administração de adenovirus recombinante, capaz de expressar LipL32 em células eucarióticas, possibilitou proteção estatisticamente significante em gerbils, 87\% (BRANGER et al., 2001). Adicionalmente vacinas de DNA compostas pelo gene lipL32 associado ao vetor 
pcDNA3.1, vetor para expressão de proteínas em células eucarióticas, possibilitou a taxa sobrevida de $60 \%$ neste mesmo modelo de infecção (BRTANGER et al., 2005).

Vacinas com bacilo Calmette-Guerin (BCG) recombinante, capazes de expressar a proteína LipL32, resultaram na proteção parcial de hamsters em meio desafio letal. Esta estratégia foi eficaz em proteger sobreviventes de manifestações clínicas e histopatológicas da doença e induziu imunidade esterilizante. Porém esta estratégia conferiu baixa taxa de proteção, até $56 \%$ em um de três experimentos (SEIXAS et al., 2007).

A imunogenidade de LipL32 aumentou quando esta proteína foi fusionada a subunidade B da toxina colérica (HABARTA et al., 2010). Esta estratégia chegou a conferir $80 \%$ de proteção, porém outros experimentos seriam necessários para comprovação da eficácia protetora conferida por esta estratégia vacinal (HAUK et al., 2009). A fusão de LipL32 fusionada com a subunidade B de LT, toxina termolábil de E. coli, possibilitou taxa de sobrevivência de $100 \%$ dos animais em dois experimentos independentes. Mas os resultados obtidos no grupo controle colocam em dúvida a confiabilidade dos experimentos. A administração de apenas LT no grupo controle possibilitou a sobrevivência de $40 \%$ dos animais (GRASSMANN et al., 2012).

O potencial protetor de proteínas da família Lig foi avaliado em diferentes estratégias vacinais, que mostraram que estas proteínas são candidatos vacinais em potencial. As proteínas LigA e LigB induziram imunidade protetiva em camundongos suscetíveis $\mathrm{C} 3 \mathrm{H} / \mathrm{HeJ}$, camundongos suscetíveis á leptospirose por serem deficientes no receptor toll-4. Neste trabalho foi reportado taxa de proteção variando de 90 á 100\%. No entanto, esta estratégia vacinal empregou adjuvante de Freund, adjuvante não licenciado para uso em humanos (KOIZUMI et al., 2004).

Trabalhos reportam que a imunidade protetiva conferida pela proteína LigA pode ser dada pela região carboxiterminal. Esta porção da proteína conferiu de $100 \%$ á $66 \%$ de proteção em hamsters desafiados (SILVA et al., 2007). Outro trabalho atribuiu o perfil protetor de LigA aos domínios sete á treze (COUTINHO et al., 2011). Porém em todos estes trabalhos adjuvante de Freund foi utilizado.

A eficácia protetora de LigA com o emprego do adjuvante hidróxido de alumínio também foi avaliada. A taxa de sobrevivência com esta estratégia foi de $100 \%$ em três experimentos independentes. Porém a baixa virulência da bactéria tornou possível a sobrevivência dos animais do grupo controle, taxa de sobrevivência variando entre 57 á $88 \%$ (PALANIAPPAN et al., 2006). 
Outras estratégias vacinais empregando proteínas LigA e LigB, como vacinas DNA, que induziram a expressão de LigA, e lipossomos contendo LigA e LigB aumentaram a sobrevida de hamsters em meio desafio letal (FAISAL et al., 2008, 2009a; YAN et al., 2009).

Adicionalmente foi observado o aumento na sobrevida no desafio de hamsters imunizados com porções conservadas de LigB fusionadas ao domínio 12 (porção variável de LigB) e porção C-terminal de LipL32. No entanto a baixa taxa de sobrevivência, 50\%, não torna esta estratégia interessante em aplicações vacinais (CAO et al., 2011).

A eficácia protetora de proteínas com o domínio OmpA, á saber Lp0607 (rMceII), Lp1118, e Lp1454 foi testada. A administração destas proteínas com o adjuvante hidróxido de alumínio possibilitou sobrevida de 70-100\% em hamsters desafiados, porém houve taxa de sobrevida de $43 \%$ no grupo controle (CHANG et al., 2007). Outros experimentos visando o aumento do perfil protetor destes candidatos compreenderam a administração destas proteínas em vesículas compostas por lipídeos de Mycobacterium smegmatis (esmegmossomos), L. biflexa sv. Patoc (leptossomos), E. coli (escleriossomos) e de fosfadidilcolina (lipossomos) (FAISAL et al., 2009b, c).

A taxa de sobrevivência dos animais imunizados com esmegmossomos, leptossomos e escleriossomos contendo as proteínas foi de 75\%. Lipossomos contendo as proteínas conferiram apenas $37,5 \%$ de sobrevivência. Adicionalmente animais imunizados apresentaram menos lesões histopatológicas e os controles negativos, vesículas vazias, não conferiram proteção. No entanto, nestes experimentos, os animais foram sacrificados assim que apresentaram sinais clínicos. Esse critério de sobrevivência pode não reproduzir dados reais sobre a taxa de sobrevivência dos animais desafiados (FAISAL et al., 2009b, c).

Outras proteínas com domínio OmpA que induziram imunidade protetora, porém baixa taxa de sobrevivência, são rLp3685 e rLp4337. A taxa de proteção variou entre 50-67\%. O reconhecido fator de virulência Loa22 induziu proteção estatisticamente insignificante, 33 á $50 \%$ (YAN et al., 2010).

Trabalhos caracterizando o potencial de proteção de proteínas hipotéticas com localização predita na membrana estão sendo realizados. rLIC12730, rLIC10494, Lsa21, Lsa66 e rLIC11030 são proteínas que induziram proteção parcial em hamster (ATZINGEN et al., 2010, 2012). As proteínas recombinante rLIC10325 e rLIC13059 aumentaram de forma estatisticamente significante a sobrevida de animais imunizados (FÉLIX et al., 2011). 


\section{OBJETIVO}

Clonar, expressar, purificar e caracterizar proteínas de Leptospira codificadas pelos genes LIC11087, LIC11228 e LIC11084 


\section{MATERIAL E MÉTODOS}

\subsection{Análise por bioinformática}

Com base nas sequencias genomicas obtidas pelo servidor publico http://aeg.lbi.ic.unicamp.br/world/lic/, oligonucleotídeos iniciadores foram desenhados com o auxilio do programa Generunner® (Hastings Software, Inc - http://www.generunner.net/) (NASCIMENTO et al., 2004b). Os genes LIC11087 (NCBI: YP_001057.1), LIC11121 (NCBI: YP_001091.1), LIC11228 (NCBI: YP_001197.1) e LIC11084 (NCBI: YP_001054.1) foram analisados por predição computacional quanto sua localização, presença de domínios conservados, e similaridade com sequencias depositadas no NCBI.

A predição da localização foi analisada submetendo as sequencias aos programas Psort - http://psort.nibb.ac.jp/ (NAKAI; KANEHISA, 1991) e Cello- http://cello.life.nctu.edu.tw/ (YU et al., 2004, 2006). O sitio de lipidação e o sítio de clivagem de cada gene foram identificados pelos programas LipoP- http://www.cbs.dtu.dk/services/LipoP/ (JUNCKER et al., 2003) e SignalP 4 (PETERSEN et al., 2011).

A presença de domínios com função conhecida foi avaliada com o empregando dos programas SMART- http://smart.embl-heidelberg.de/help/smart_about.html (LETUNIC et al., 2012; SCHULTZ et al., 1998) e PFAM - http://pfam.sanger.ac.uk/ (FINN et al., 2006; SONNHAMMER et al., 1997)

A similaridade destes genes com sequencias depositadas no banco de dados do NCBI foi avaliada por Blast (ALTSCHUL et al., 1990, 1997). O alinhamento destes genes com outros genes similares foi realizado pelo programa ClustalW2http://www.ebi.ac.uk/Tools/msa/clustalw2/(LARKIN et al., 2007).

\subsection{Linhagens de Leptospira e condições de cultivo}

Nos experimentos foram empregadas linhagens de leptospiras atenuadas em cultura. As seguintes espécies foram estudadas: L. interrogans (sorovars Copenhageni linhagem M20, Canicola linhagem Hound Utrecht IV, Icterohaemorrhagiae linhagem RGA e Pomona linhagem Pomona), L. borgpetersenii (sorovars Castellonis linhagem Castellon 3 e Whitcombi linhagem Whitcomb), L. kirschneri (sorovars Cynoptery linhagem 3522C e 
Grippothyphosa linhagem Moskva V), L. santarosai sorovar Shermani linhagem $1342 \mathrm{~K}, \mathrm{~L}$ noguchii sorovar Panama linhagem CZ 214), L. biflexa sorovar Patoc linhagem Patoc 1.

Leptospiras foram cultivadas por 7 dias na temperatura de $30{ }^{\circ} \mathrm{C}$ em meio EMJH, Ellinghausen-McCullough-Johnson-Harris (Difco ${ }^{\mathrm{TM}}$, Le Pont de Claix, França). O meio foi suplementado com soro de coelho (10\%), L-asparagina $(0.015 \%)$, piruvato de sódio $(0.001 \%)$, cloreto de cálcio $(0.001 \%)$, cloreto de magnésio $(0.001 \%)$, peptona $(0.03 \%)$ e extrato de carne (0.02\%) (ELLINGHAUSEN; MC CULLOUGH, 1965; JOHNSON; HARRIS, 1967).

Nos procedimentos de clonagem foi empregada E. coli DH5 $\alpha$ (HANAHAN, 1983). Para obtenção da proteína recombinante foram utilizadas as cepas de expressão E. coli BL21 SI ("Salt Induced"), E. coli BL21 (DE3) e E. coli BL21 (DE3) Star pLysS (BHANDARI et al., 1997; STUDIER et al., 1990, 1991).

O cultivo da cepa E. coli DH5 $\alpha$ foi realizado em meio LB (Luria Bertani), meio composto por $0,5 \%$ de extrato de levedura, $1 \%$ de triptona e $1 \%$ de $\mathrm{NaCl}$. O cultivo foi mantido á $37^{\circ} \mathrm{C}$, por $24 \mathrm{~h}$, em meio rotação de $200 \mathrm{rpm}$. A pressão de seleção na cultura foi realizada pela adição de ampicilina $(100 \mathrm{~g} / \mathrm{mL})$.

O cultivo de E. coli BL21 SI foi similar ao E. coli DH5 $\alpha$ diferindo apenas no meio empregado. Esta cepa foi cultivada em meio 2 YTON. Este meio é composto por $1 \%$ de extrato de levedura e $1,6 \%$ de triptona.

As cepas E. coli BL21 (DE3) e E. coli BL21 (DE3) Star pLysS foram cultivadas da meio LB a $30{ }^{\circ} \mathrm{C}$. A pressão de seleção nas culturas de E. coli BL21 (DE3) foi realizada pela adição de ampicilina (100 $\mathrm{g} / \mathrm{mL})$ e adicionalmente pela adição de cloranfenicol $(100 \mathrm{~g} / \mathrm{mL})$ nas culturas de E. coli BL21 (DE3) Star pLysS.

\subsection{Isolamento de DNA genomico}

A cultura bacteriana foi centrifugada por 20 min á $4{ }^{\circ} \mathrm{C}$ em $3.200 \mathrm{rad}$. As células foram lisadas em tampão T.E. (Tris 10mM e EDTA 1M), SDS $10 \%$ e Proteinase K (20 $\mathrm{mg} / \mathrm{ml}$ ), $1 \mathrm{~h}$ á $37{ }^{\circ} \mathrm{C}$. Após isso, foi realizada a preciptação das proteínas com adição de fenol/clorofórmio/ álcool isoamílico na proporção 25:24:1. As amostras foram lavadas respectivamente com clorofórmio/álcool isoamilico (24:1), acetato de sódio (décima parte do volume obtido), isopropanol (60\%) e etanol $70 \%$. No final dos procedimentos o material foi ressuspenso em $\mathrm{H} 20$ miliQ e mantido em $-20{ }^{\circ} \mathrm{C}$ (SAMBROOK et al., 1989). 


\subsection{Amplificação dos genes}

Os genes foram amplificados com os oligonucletídeos iniciadores descritos na tabela 1. Na reação polimerase em cadeia foi empregado como molde 100 ng do DNA genomico de Leptospira ssp; $1 \mathrm{U}$ da enzima Taq polimerase; $300 \mathrm{ng}$ de oligonucletídeos iniciadores (F e $\mathrm{R}) ; 0,2 \mathrm{mM}$ de deoxiribonucleotideos (dNTP); $2 \mathrm{mM}$ de $\mathrm{MgCl}$; e 1x Tampão (Invitrogen Corporation, Califórnia, C.A., E.U.A.). O ciclo de amplificação empregado para amplificação dos genes foi desnaturação á $94{ }^{\circ} \mathrm{C}$ por $30 \mathrm{~s}$, anelamento por $30 \mathrm{~s}$ (temperaturas empregadas Tabela 1) e extensão á $72{ }^{\circ} \mathrm{C} 1 \mathrm{~min}$.

Tabela 1- Características dos oligonucleotídeos iniciadores empregados no processo de clonagem

\begin{tabular}{|c|c|c|c|}
\hline Gene ID & $\begin{array}{l}\text { Tamanho do } \\
\text { produto de PCR }\end{array}$ & $\begin{array}{l}\text { Temperatura de } \\
\text { Anelamento }\end{array}$ & Oligonucleotídeo sintético \\
\hline LIC11087 & 889 pb & $54{ }^{\circ} \mathrm{C}$ & $\begin{array}{l}\text { F:5' } \frac{\text { CTCGAGGGAGATTCCAGAAAGGAAAAC }}{\text { XhoI }} \\
\text { R:5' } \frac{\text { AAGCTTACCTGTGTGATGCGCTTCT }}{\text { HindIII }}\end{array}$ \\
\hline LIC11121 & $1052 \mathrm{pb}$ & $54{ }^{\circ} \mathrm{C}$ & $\begin{array}{l}\text { F:5' } \frac{\text { CTCGAGAACGTTCAATATAATCAAGGT }}{\text { XhoI }} \\
\text { R:5’ } \frac{\text { AAGCTTAAGGTTTTTCGAAGTAGTAGT }}{\text { HindIII }}\end{array}$ \\
\hline LIC11228 & $1403 \mathrm{pb}$ & $48^{\circ} \mathrm{C}$ & $\begin{array}{l}\mathrm{F}: \frac{\text { GGATCCGAACAAATCGTATC }}{\text { BamHI }} \\
\text { R: GGGGTACCTTAGAATTCTATTGT } \\
\text { KpnI }\end{array}$ \\
\hline LIC11084 & $1126 \mathrm{pb}$ & $60{ }^{\circ} \mathrm{C}$ & $\begin{array}{l}\text { F: GGATCCGTACAAAATGGAACTGAAGGT } \\
\text { R: 5' } \frac{\text { BAmHI }}{\text { HindIII }}\end{array}$ \\
\hline
\end{tabular}

Nota 1. Abreviaturas: ID, Identificação dos genes no projeto genoma de L. interrogans sorovar Copenhageni (sequencias disponíveis em http://aeg.lbi.ic.unicamp.br/world/lic/; F, "foward"; R, "reverse"; pb, pares de base. Os sítios de restrição inseridos pelos iniciadores estão sublinhados nas sequencias descritas na tabela.

\subsection{Extração de RNA}

RNA de leptospira foi extraído com o emprego do reagente TRIZOLC, segundo orientações do fabricante (Invitrogen). $20 \mathrm{~mL}$ de cultura foram centrifugados por $30 \mathrm{~min}$ á 
$4600 \mathrm{rad}\left(4^{\circ} \mathrm{C}\right)$. As células foram lavadas com PBSls e centrifugadas conforme anteriormente descrito.

A amostra foi ressuspensa em $2 \mathrm{~mL}$ de TRIZOL@ $@$ e então centrifugada á $15.500 \mathrm{rad}$ por 10 min á $\left(4^{\circ} \mathrm{C}\right)$. O sobrenadante foi transferido para microtubos novos, e foi adicionado 0,4 mL de clorofórmio a cada amostra. A amostra foi agitada manualmente por $15 \mathrm{~s}$ e então centrifugada por $15.500 \mathrm{rad}, 10 \mathrm{~min}$ á $4{ }^{\circ} \mathrm{C}$. A fase aquosa foi transferida para tubos novos e tratada com $1 \mathrm{~mL}$ de isopropanol. A amostra foi homogeneizada e incubada por 10 min á 4 ${ }^{\circ} \mathrm{C}$. A amostra foi centrifugada por $15.500 \mathrm{rad}, 10 \mathrm{~min}$ á $4{ }^{\circ} \mathrm{C}$, e o sobrenadante foi descartado. A amostra foi tratadas com $1 \mathrm{~mL}$ de etanol $75 \%$ e então centrifugada por 15.500 $\mathrm{rad}, 10 \mathrm{~min}$ á $4{ }^{\circ} \mathrm{C}$. O tratamento com etanol foi realizado duas vezes. O sedimento foi mantido á temperatura ambiente, para evaporação do etanol, e então ressuspenso em água tratada com DEPC ( (invitrogen). O RNA obtido foi analisado por espectrometria quanto sua pureza (razão 260/230) e concentração (razão 260/280).

\subsection{Síntese de DNA complementar á transcritos de leptospira}

RNA extraído de culturas de leptospira foi utilizado como molde para síntese de DNA complementar (cDNA) por reagentes do Kit SuperScript ${ }^{\mathrm{TM}}$ III Reverse Transcriptase (Invitrogen). Primeiramente degradação de DNA contaminante foi feita pelo tratado das amostras com a enzima DNase I Amplification Grade (Invitrogen). $1 \mathrm{~g}$ de RNA foi tratado com $1 \mathrm{U}$ de DNase I á temperatura ambiente, posteriormente a enzima foi inativada com 2,5 $\mathrm{mM}$ de EDTA por $10 \min$ á $65^{\circ} \mathrm{C}$.

Para síntese de cDNA as amostras foram tratadas com reagentes do kit SuperScript ${ }^{\mathrm{TM}}$ III Reverse Transcriptase (Invitrogen). Cada amostra foi incubada por 5 min á $65{ }^{\circ} \mathrm{C}$ com 25 ng de iniciadores aleatórios ("random hexamers") e $10 \mathrm{mM}$ dNTP Mix. As amostras foram mantidas por 1 min em gelo. Então foram adicionados os demais reagentes necessários á reação, tampão fornecido pelo fabricante ("RT Buffer”, $1 \mathrm{X}), \mathrm{MgCL}_{2}(5 \mathrm{mM}), \mathrm{DTT}(10 \mathrm{mM})$, RNase OUT(40 U) e enzima superscript III (200 U). A reação foi realizada em termociclador com o seguinte ciclo: $25^{\circ} \mathrm{C}$ por $10 \mathrm{~min}, 50{ }^{\circ} \mathrm{C}$ por $50 \mathrm{~min}, 85^{\circ} \mathrm{C}$ por 5 min e $4{ }^{\circ} \mathrm{C}$ por 5 min. RNA contaminante foi degradado com RNase $\mathrm{H}(1 \mathrm{U})$ por 20 min á $37{ }^{\circ} \mathrm{C}$. O cDNA foi armazenado em $-20{ }^{\circ} \mathrm{C}$ e empregadas em reações de PCR para a análise da expressão dos genes em estudo. Como controle negativo dos experimentos realizamos foram realizadas reações com as amostras sem adição da enzima superscript. 


\subsection{Preparo de extrato proteico total de leptospiras e $E$. coli}

Culturas de leptospiras foram centrifugadas por $30 \mathrm{~min}$ á $4.600 \mathrm{rad}\left(4{ }^{\circ} \mathrm{C}\right)$, condições para manter a integridade celular. As células foram lavadas com PBSls e centrifugadas, procedimento realizado três vezes. As células foram ressuspensas em tampão para eletroforese de proteínas de maneira a ficarem 100 x mais concentradas. As amostras foram aquecidas á $100{ }^{\circ} \mathrm{C}$ por 10 min e mantidas em $-20{ }^{\circ} \mathrm{C}$.

\subsection{Extrato de $E$. coli}

A supressão de anticorpos contra proteínas contaminantes ocorreu pela adsorção do soro em extrato de E. coli. O extrato de E. coli foi produzido com células das cepas empregadas na expressão das proteínas. Células não transformadas foram cultivadas por $24 \mathrm{~h}$. Estas células foram coletadas por centrifugação e ressuspensas no tampão de lise (40 mM Tris-HCl pH 8; 150 mM NaCl; 200 g/mL lisozima; 2 mM PMSF e 1\% Triton X-100). A lise das células ocorreu pelo processo de sonicação das amostras em banho de gelo (GRUBER; ZINGALES, 1995).

\subsection{Western-blotting para análise da expressão de proteínas}

A detecção de proteínas nativas em culturas de leptospiras e proteínas recombinantes em células de E. coli foi realizada por immunoblotting. Amostras proteicas foram submetidas a eletroforese em gel de poliacrilamida/SDS $12,5 \%$ e posteriormente foram transferidas á uma membrana de nitrocelulose (Hybond ECL,GE Healthcare, Buckingmshire, Bucks, Reino Unido) em sistema semi-úmido (GE).

O processo de transferência foi realizado por $1 \mathrm{~h}$ sob amperagem de $0,8 \mathrm{~mA}$ por cm2. O tampão empregado durante o procedimento foi Tris-Glicina, acrescido de 1,85\% de SDS. A eficiência da transferência foi avaliada por coloração das proteínas imobilizadas na membrana com Ponceau S (Sigma, Missouri, M.O., E.U.A.). A membrana foi descorada com PBS/Tween $0,05 \%$ e bloqueada com PBS contendo $10 \%$ de leite desnatado por $18 \mathrm{~h}$ a temperatura de $4^{\circ} \mathrm{C}$.

A membrana foi lavada por 3 vezes com PBS/Tween 0,05\%, por $10 \mathrm{~min}$ cada lavagem. Para detecção das proteínas nativas em leptospiras a membrana foi tratada com 
anticorpos policlonais homólogos as respectivas proteínas. Nestes experimentos a membrana foi incubada com PBS contendo os anticorpos policlonais, na diluição 1:100, por 2 h á temperatura ambiente. A membrana foi lavada por 3 vezes com PBS/Tween 0,05\%, por 10 min cada lavagem. E então foi incubada com anti-IgG de camundongo conjugado com peroxidase (Sigma) na diluição 1:5.000, por $1 \mathrm{~h}$ á temperatura ambiente. A membrana foi lavada por 3 vezes com PBS/Tween 0,05\%, por 10 min cada lavagem.

A detecção da proteína recombinante foi realizada por anticorpos monoclonais anti 6x histidina conjugados com peroxidase (Sigma). As proteínas imobilizadas na membrana foram detectadas com o tratamento da membrana com PBS contendo estes anticorpos na diluição 1:5.000.

A imunodetecção foi evidenciada com o emprego do kit ECL Western Blotting Detection Reagents (GE Healthcare). A quimiluminescência foi detectada pela exposição da membrana a filmes de raio-X (Kodak) ou por foto-documentador (gel logic pro 2200, Carestream).

\subsection{Clonagem}

Os genes amplificados foram ligados no vetor de clonagem pGEM-T easy (PROMEGA, Madison, Wisconsin, EUA) e subclonados no vetor de expressão pAE. Os produtos de PCR resultante da amplificação do gene foram analisados por eletroforese em gel de agarose $1 \%$ em tampão TAE (40 mM Tris-acetato e 1 mM EDTA) corado com Gel Red ${ }^{\mathrm{TM}}$ (Biotium, Inc, California, C.A., EUA). Os clones recombinantes foram sequenciados para confirmação da clonagem.

Para ligação dos produtos de PCR no vetor pGEM-T easy (PROMEGA), os amplicons foram separados por eletroforese e excisados do gel pelo emprego do kit "GFxPCR DNA and gel band purification" (GE Healthcare, , Buckingmshire, Reino Unido). Os produtos obtidos foram quantificados em espectrofotômetro no comprimento de onda de $260 \mathrm{~nm}$.

Os insertos foram ligados ao vetor pGEM-T easy (PROMEGA), segundo orientações do fabricante (Figura 1). A reação foi empregada para transformação de E. coli DH5 $\alpha$ competente (HANAHAN, 1983). Todo volume da reação de ligação ao vetor pGEM-T easy (PROMEGA) foi adicionado á microtubo contendo E. coli DH5 $\alpha$ competente. As células foram incubadas por $30 \mathrm{~min}$ em banho de gelo. Para a internalização de DNA exógeno, ás células foram submetidas a choque térmico, e assim as amostras foram mantidas por $30 \mathrm{~s}$ á 42 
${ }^{\circ} \mathrm{C}$ e por 2 min á $0{ }^{\circ} \mathrm{C}$. Para regeneração as células transformadas foram cultivadas sob agitação em meio LB, á $37^{\circ} \mathrm{C}$ por 1 hora. As amostras foram plaqueada em LB contendo 100 $\mathrm{g} / \mathrm{mL}$ de ampicilina, $100 \mathrm{mM}$ de IPTG e $50 \mathrm{mg} / \mathrm{mL}$ de X-gal.

Os clones recombinantes foram pré-selecionados a partir da coloração que apresentaram. As colônias positivas apresentavam coloração branca devido a inativação do gene codificante para galactose. Essas colônias foram cultivadas em meio LB (contendo 100 $\mathrm{g} / \mathrm{mL}$ de ampicilina) por $18 \mathrm{~h}$ á $37^{\circ} \mathrm{C}$, sob agitação. As células foram centrifugadas e a confirmação da clonagem ocorreu pela amplificação dos genes de interesse com iniciadores específicos.

O DNA plasmidial (pGEM-T Easy/inserto) do material positivo foi extraído com a utilização do kit "Plasmid prepmini spin" (GE Healthcare). A extração foi realizada segundo orientações do fabricante. Os insertos foram liberados do vetor por digestão com as enzimas de restrição apropriadas, sítio de restrição empregado para as clonagens dos genes estão descritos na tabela 1.

Após digestão, a liberação dos insertos foi avaliada por eletroforese em gel. As bandas com tamanho esperado foram purificadas do gel pelo kit "GFX PCR DNA and Gel Band Purification" (GE Healthcare). Os insertos foram ligados ao vetor de expressão pAE (RAMOS et al., 2004) pela ação da enzima T4 ligase (GE Healthcare).

$\mathrm{O}$ vetor pAE foi previamente digerido com as mesmas enzimas de restrição utilizadas no processo de clonagem e foi desfosforilado com $1 \mathrm{U}$ da enzima CIAP, Alkaline Phosphatase, Calf Intestinal (Invitrogen).

A proporção entre inserto e vetor empregada na reação de ligação foi de 3:1. A reação foi realizada á $25^{\circ} \mathrm{C}$ por 4 h. Células de $E$. coli DH5 $\alpha$ competentes foram transformadas com a mistura de ligação e cultivadas em LB/ Amp á $37^{\circ} \mathrm{C}$ por $18 \mathrm{~h}$. 
Figura 1- Vetores empregados no processo de clonagem dos genes

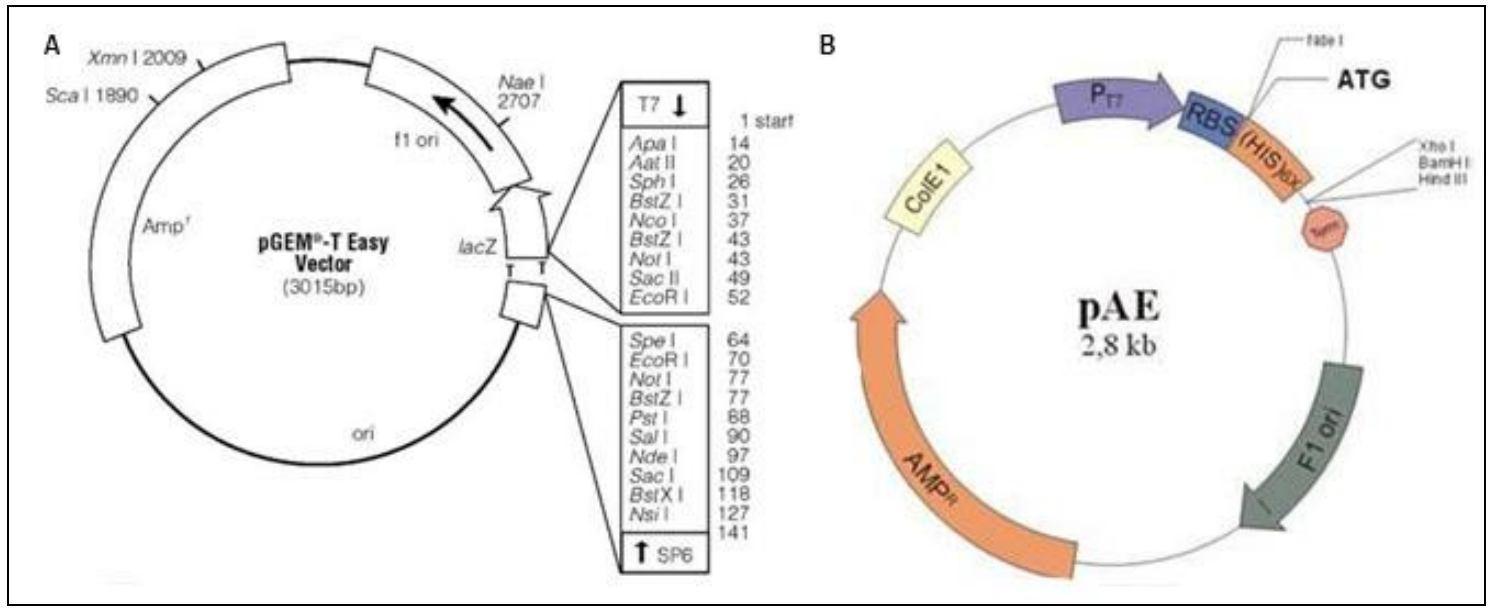

Vetores empregados no processo de clonagem dos genes. (A) Mapa do vetor pGEM-T easy. flori: origem de replicação. Ampr: gene de resistência a ampicilina. lacZ: gene para metabolismo de lactose ( $\beta$-galactosidase). (B) Mapa do vetor de expressão pAE . PT7: promotor do fago T7, (His) 6x: sequência codificadora para seis resíduos de histidina. RBS: sítio de ligação ao ribossomo. ATG: códon de início da transcrição. Term: região de terminação de transcrição (T7). F1ori: origem de replicação. AmpR: gene de resistência à ampicilina.

A confirmação da presença do inserto nos clones recombinantes foi dada com a amplificação dos genes de interesse. Outra avaliação das colônias positivas foi dada pela análise de restrição de plasmídeos extraídos dos clones positivos.

Os clones positivos foram sequenciados utilizando os oligonucleotídeos foward $5^{\prime}$ TAATACGACTCACTATAGGG 3' ou reverse 5' TATGCTAGTTATTGCTCAG 3`, que se anelam ao vetor pAE na região do gene T7 (RAMOS et al., 2004). Foi utilizado o sequenciador automático ABI PRISM(R) 3100 Genetic Analyzer (Life Technologies, Califórnia, C.A., E.U.A.) e o método da terminação da cadeia para sequenciamento das amostras (SANGER et al., 1977). A reação foi montada conforme orientações do fabricante num volume final de 201 contendo DNA molde $150 \mathrm{ng}, 1,6$ pmoles de oligonucleotídeo e 2 1 do tampão BigDye ${ }^{\circledR}$ (Life Technologies) que contém: ddNTPs marcados com corantes fluorescentes específicos, dNTPs e Taq DNA polimerase. A reação foi realizada em termociclador seguindo a rotina de 40 ciclos de a) $94{ }^{\circ} \mathrm{C}$ por $10 \mathrm{~s}$; b) $52{ }^{\circ} \mathrm{C}$ por $20 \mathrm{~s}$; c) $60{ }^{\circ} \mathrm{C}$ por 4 min. A seguir, a mistura foi precipitada com isopropanol $75 \%$ e centrifugada $50 \mathrm{~min}$ a $11.500 \mathrm{rad}$ a temperatura ambiente. O precipitado de DNA foi lavado com 70\% etanol, seco a vácuo em centrifuga e ressuspenso para aplicação em $15 \quad 1$ de formamida HiDi (Life Technologies). Os cromatogramas obtidos foram analisados com o auxílio dos programas 
públicos: Chromas (http://www.mb.mahidol.ac.th/pub/chromas/chromas.htm) e Blast 2 (http://www.ncbi.nlm.nih.gov/blast/bl2seq/wblast2.cgi) (ALTSCHUL et al., 1990, 1997).

\subsection{Expressão das proteínas recombinantes}

A indução da expressão das proteínas recombinantes ocorreu nas cepas de expressão E. coli BL21 SI (Salt Induced), E. coli BL21 (DE3) e E. coli BL21 (DE3) Star pLysS (BHANDARI et al., 1997; STUDIER et al., 1991, 1990).

A cepa de E. coli BL21 (SI) possui o gene T7 RNA polimerase integrado ao genoma sob o controle do promotor proU, induzível por $\mathrm{NaCl}$ (BHANDARI et al., 1997). As diferentes cepas de E. coli DE3 também possuem o gene da T7 RNA polimerase, sob controle do promotor lac UV5, o qual é induzido por IPTG (STUDIER et al., 1990). A cepa E. coli BL21 Star (DE3) pLysS, por sua vez, carrega o plasmídeo pLys que produz pequenas quantidades de T7 lisozima, um inibidor natural da T7 RNA polimerase. A redução da expressão basal da T7 RNA polimerase e permite a expressão de proteínas recombinantes mais estáveis, particularmente para proteínas tóxicas (STUDIER et al., 1991).

Bactérias competentes E. coli BL21 SI foram transformadas com o plasmídeo recombinante e cultivadas em meio 2 YT/ON contendo $100 \mathrm{~g} / \mathrm{mL}$ de ampicilina por $18 \mathrm{~h}$. As culturas saturadas foram diluídas 1:20 e incubadas até atingir uma densidade óptica entre 0,6 e 0,8 no comprimento de onda $600 \mathrm{~nm}$. A indução do promotor proU foi realizada com a adição de $\mathrm{NaCl}$ na concentração $300 \mathrm{mM}, 150 \mathrm{mM}$ e $75 \mathrm{mM}$. As culturas foram incubadas por $4 \mathrm{~h}$.

O processo de indução em E. coli BL21 (DE3) e E. coli BL21 (DE3) Star pLysS ocorreu por IPTG foi semelhante, porém o meio utilizado foi o LB contendo $100 \mathrm{~g} / \mathrm{mL}$ de ampicilina para E. coli BL21 (DE3) ou $100 \mathrm{~g} / \mathrm{mL}$ de ampicilina e $100 \mathrm{~g} / \mathrm{mL}$ de cloranfenicol para seleção de E. coli BL21 (DE3) Star pLysS. A temperatura de incubação foi de $37^{\circ} \mathrm{C}$ e a indução do promotor lac UV5 foi realizada adicionando-se $0,25 \mathrm{mM} ; 0,5 \mathrm{mM}$ e 1 $\mathrm{mM}$ de IPTG. Após indução as culturas foram incubadas sob a mesma temperatura por um período de $4 \mathrm{~h}$.

A seguir as bactérias foram centrifugadas $\left(3.200 \mathrm{rad} / 15 \mathrm{~min} / 4{ }^{\circ} \mathrm{C}\right)$ e os sedimentos ressuspensos em tampão de lise (40 mM Tris-HCl pH 8; $150 \mathrm{mM} \mathrm{NaCl} ; 200$ g/mL lisozima; $2 \mathrm{mM}$ PMSF e 1\% Triton X-100). As bactérias foram então lisadas em banho de gelo por sonicação (50 Hz por 5 min, ciclo continuo) e centrifugadas por $15 \mathrm{~min}, 4{ }^{\circ} \mathrm{C}$ á $6.400 \mathrm{rad}$. 
Após procedimento de sonicação o sobrenadante do lisado celular foi separado de corpúsculos de inclusão por centrifugação, 15 min á $6.400 \mathrm{rad}$. Os sedimentos formados foram ressuspensos em tampão de desnaturação (40 mM Tris- $\mathrm{HCl} \mathrm{pH} 8 ; 150 \mathrm{mM} \mathrm{NaCl} ; 5$ $\mathrm{mM}$ de $\beta$ mercaptoetanol e $8 \mathrm{M}$ uréia). Alíquotas do sobrenadante e ou do sedimento do lisado celular foram analisadas por eletroforese em gel de poliacrilamida/SDS 12,5\%.

\subsection{Purificação}

A proteína codificada pelo gene LIC11087 foi purificada a partir de $400 \mathrm{~mL}$ de cultura induzida. A proteína foi expressa em E. coli BL21 (DE3) e purificada por cromatografia de afinidade ao metal.

As células foram coletadas por centrifugação lisadas como anteriormente descrito. A proteína foi solubilizada no tampão (8 M ureia; $20 \mathrm{mM}$ Tris- $\mathrm{HCl}$ pH12;0,5 M NaCl e $5 \mathrm{mM}$ imidazol) por $18 \mathrm{~h}$. A amostra foi centrifugada por $15 \mathrm{~min}$, á $6.400 \mathrm{rad}$, e o sobrenadante foi empregado na purificação da proteína pelo aparelho ÄKTAPrime plus (GE Healthcare). O procedimento de purificação foi realizado com coluna HiTrap ${ }^{\mathrm{TM}}$ contendo resina "Chelating HP” (GE Healthcare).

O processo de purificação se iniciou com a adsorção da proteína na coluna carregada com níquel. Antes do inicio da purificação a coluna foi previamente tratada com tampão empregado para a solubilização da proteína. A seguir a renaturação da proteína foi realizada com o tratamento da coluna com tampões com concentrações decrescentes de ureia (de 8 a 0 M), e a exclusão de proteínas contaminantes, foi realizada tratando a coluna com tampões contendo baixa concentração de imidazol. Ao final a proteína rLIC11087 foi eluída no tampão $20 \mathrm{mM}$ Tris- $\mathrm{HCl}$ pH12; $200 \mathrm{mM} \mathrm{NaCl}$ e 0,5 M Imidazol.

A proteína codificada pelo gene LIC11228, expressa na forma insolúvel pela bactéria E. coli BL21 (SI) e foi purificada a partir de $400 \mathrm{~mL}$ de cultura. Após a lise celular, corpúsculos de inclusão, coletados por centrifugação, foram solubilizados no tampão $8 \mathrm{M}$ ureia; $20 \mathrm{mM}$ Tris- $\mathrm{HCl}$ (pH12); 0,15 M NaCl. A amostra foi renaturada por gotejamento em 2 $\mathrm{L}$ do tampão de renaturação $(20 \mathrm{mM}$ tris pH12 e $0,15 \mathrm{M} \mathrm{NaCl})$. O procedimento de purificação foi realizado com a adsorção da proteína na resina "Chelating Sepharose" (GE Healthcare) previamente carregada com níquel e com o tampão $20 \mathrm{mM}$ Tris- $\mathrm{HCl}$ (pH12); 0,15 $\mathrm{M} \mathrm{NaCl}$. A retirada de proteínas contaminantes foi realizada tratando a coluna com tampão 20 mM Tris- $\mathrm{HCl}$ (pH12); 0,15 M NaCl contendo concentrações crescentes de imidazol (5, 20, 40 
e $60 \mathrm{mM}$ ). A proteína de interesse foi eluída em $15 \mathrm{~mL}$ do tampão $20 \mathrm{mM}$ Tris- $\mathrm{HCl}$ (pH12); $0,15 \mathrm{M} \mathrm{NaCl}$ acrescido de $1 \mathrm{M}$ imidazol.

A proteína codificada por LIC11084 foi expressa pela bactéria E. coli BL21 (SI) e purificada a partir da fração solúvel. No processo de purificação foram empregados $200 \mathrm{~mL}$ de cultura induzida. As células foram coletadas por centrifugação e lisadas. $\mathrm{O}$ sobrenadante do lisado celular foi diluído no tampão $20 \mathrm{mM}$ Tris- $\mathrm{HCl}$ pH12; 0,5 M NaCl e 5 mM imidazol e empregado no processo de purificação. A purificação desta proteína foi realizada pelo aparelho ÄKTAPrime plus (GE Healthcare) e a coluna empregada no procedimento foi HiTrap ${ }^{\mathrm{TM}}$ contendo resina "Chelating HP” (GE Healthcare). A proteína foi adsorvida na coluna, previamente carregada com níquel e equilibrada com o tampão de diluição da amostra. Proteínas contaminantes foram retiradas com lavagens da coluna com tampões com concentrações crescentes de imidazol, e a eluíção de rLIC11084 foi feita com tampão contendo 0,5 M de Imidazol.

Após o procedimento de purificação, as frações coletadas foram analisadas em gel de poliacrilamida/SDS 12,5\% (SDS-PAGE). As frações contendo as proteínas rLIC11087 e rLIC11084 foram dialisadas em $2 \mathrm{~L}$ de tampão $20 \mathrm{mM}$ Tris- $\mathrm{HCl}$ pH12; $500 \mathrm{mM} \mathrm{NaCl} \mathrm{e}$ 0,01\% glicina. A proteína rLIC11228 foi dialisada em 2 L de tampão $20 \mathrm{mM}$ Tris-HCl pH12; $150 \mathrm{mM} \mathrm{NaCl}$ e $0,01 \%$ glicina. O processo de diálise foi realizado á $4{ }^{\circ} \mathrm{C}$ por $2 \mathrm{~h}$. Foram realizadas duas trocas. A concentração das proteínas recombinantes foi estimada por densitometria. Após eletroforese, bandas referentes as proteínas purificadas foram comparadas a bandas geradas com concentrações pré-estabelecidas de albumina (BSA Bovine Serum Albumin). As bandas foram avaliadas pelo programa Gel-Quant (AMPL SOFTWARE PTY LTD, Turramurra, Australia).

\subsection{Espectroscopia circular (CD) das proteínas recombinantes}

A proteína rLIC11087 (10 M) foi dialisada em tampão fosfato de sódio, pH 7.4, 10 $\mathrm{mM}$ (Sambrook et al., 1989), três trocas á $4{ }^{\circ} \mathrm{C}$. As proteínas rLIC11228 e rLIC11084 foram dialisadas com duas trocas em tampão $10 \mathrm{mM}$ tris pH12 e $20 \mathrm{mM} \mathrm{NaCl}$. Os espectros de CD foram expressos em termos de elipcidade molar residual:

$[\Phi]=\Phi \times 100 \times M$ 
$\Phi$ é elipcidade, M é a massa molecular da proteína (Daltons), C é a concentração da proteína $(\mathrm{mg} / \mathrm{mL})$, I é o caminho ótico $(\mathrm{cm})$ e n é o número de resíduos de aminoácidos da proteína (KELLY et al., 2005).

A obtenção dos espectros ocorreu após leitura das amostras no aparelho Espectropolarímetro Jasco J-810 (Japan Spectroscopic, Tokyo, Japão). A leitura foi realizada á temperatura de $20{ }^{\circ} \mathrm{C}$. Os resultados foram avaliados apartir da média de 5 leituras. Os valores obtidos foram comparados á estruturas depositadas no programa $\mathrm{K}_{2} \mathrm{D}_{2}$ (PEREZIRATXETA; ANDRADE NAVARRO, 2007).

\subsection{Imunização de camundongos}

Camundongos BalbC, fêmeas, de 6 semanas foram imunizados no dorso e subcutaneamente com $10 \mathrm{~g}$ das proteínas recombinantes. O adjuvante empregado foi Alhydrogel $\left(2 \% \mathrm{Al}(\mathrm{OH})_{3}\right.$, Brenntag Biosector, Frederikssund, Dinamarca). Os grupos experimentais foram compostos de cinco animais. No grupo controle foi administrado PBS e adjuvante. Após o experimento os animais foram sacrificados com $\mathrm{CO}_{2}$. Os animais foram imunizados com uma dose e dois reforços no intervalo de 15 dias.

As amostras de sangue coletadas foram mantidas á $4{ }^{\circ} \mathrm{C}$ por $18 \mathrm{~h}$. O coágulo foi separado do soro por centrifugação (10 min á $6.400 \mathrm{rad})$. O soro coletado foi mantido em -20 ${ }^{\circ} \mathrm{C}$.

\subsection{Detecção de anticorpos IgG por ELISA}

A detecção de anticorpos policlonais no soro de animais imunizados foi realizada por ensaio imunoenzimático ELISA (Enzyme Linked Immuno Sorbent Assay). Foram empregadas nos experimentos placas Costar® High binding de 96 poços, (Corning, Virgínia, V.A., E.U.A.). Cada poço recebeu $250 \mathrm{ng}$ de proteína recombinante diluída em 501 de tampão carbonato 0,05 M pH9,6. A placa foi incubada $18 \mathrm{~h}$ á temperatura ambiente. A placa foi lavada três vezes com PBS-tween 0,05\%. Os poços foram bloqueados com 2001 de uma solução contendo PBS e $10 \%$ de leite desnatado, por duas horas á $37 \%$. 
Em placas de microdiluição, os soros foram diluídos de 1:200 á 1:409.600 em PBS 1x contendo $10 \%$ de extrato de E.coli. As placas foram incubadas por $1 \mathrm{~h}$ á $37{ }^{\circ} \mathrm{C}$. Após descarte da solução de bloqueio foi adicionado 501 dos soros. A placa foi incubada por $1 \mathrm{~h}$ á $37^{\circ} \mathrm{C}$.

Após lavagens foi adicionado 501 de PBS contendo anti-IgG de camundongo conjugado com peroxidase na diluição 1:5.000. A reação enzimática foi revelada pela adição de $1 \mathrm{mg} / \mathrm{mL}$ de OPD ( $\delta$-phenylenediamina, Sigma) diluído em tampão fosfato-citrato $\mathrm{pH} 5,0$ contendo 0,03\% (vol/vol) de peróxido de hidrogênio (100 $\mu \mathrm{L}$ por poço). Após 15 min de incubação, a reação enzimática foi interrompida pela adição de $50 \mu \mathrm{L}$ de solução de $\mathrm{H}_{2} \mathrm{SO}_{4} 4$ N.

A densidade ótica (DO) da reação foi avaliada no comprimento de onda de $492 \mathrm{~nm}$, em espectrofotômetro (Multiskan FC, Thermo Scientific, Massachusetts, MA, EUA). A densidade ótica obtida com a leitura das amostras de soro foi subtraída da densidade ótica de poços que foram incubados com antígeno e não tratadas com anticorpos. O título individual foi determinado como sendo a maior diluição com valor de DO acima de 0,1 .

\subsection{Avaliação da resposta celular}

A proliferação de esplenócitos e a secreção de citocinas a partir de células de animais imunizados com as proteínas recombinantes foram avaliadas in vitro. O baço de animais imunizados foi coletado assepticamente e, mantido á $0{ }^{\circ} \mathrm{C}$ em meio RPMI contendo penicilina (100 IU/ml) e estreptomicina (10 g/ml). As células foram obtidas após maceração do órgão e coletadas por centrifugação $\left(4^{\circ} \mathrm{C}, 6.400 \mathrm{rad}, 10 \mathrm{~min}\right.$, “no break"). Após lavagem em PBS estéril as hemácias foram lisadas com água em agitação por 10 s e meio RPMI foi adicionado.

As células foram contadas em câmara de Neubauer e semeadas em placas para cultura celular com 2,5 g de proteína ou 5 g de concanavalina A (Sigma). Para avaliação da proliferação de esplenócitos, $10^{5}$ células foram cultivadas em meio RPMI completo em placas para cultura celular de 96 poços (Corning). Para avaliação da secreção de citocinas $10^{6}$ foram cultivadas em placas de 24 poços (BD Falcon ${ }^{\mathrm{TM}}$, New Jersey, N.J., E.U.A.). As células foram incubadas por dois dias á $37{ }^{\circ} \mathrm{C}$ e $5 \% \mathrm{CO}_{2}$.

A proliferação dos esplenócitos foi analisada com emprego do kit colorimétrico BrdU (Roche applyed science, Bavaria, Alemanha) . BrdU (5-bromo-2'-deoxyuridine) é um análogo de timidina que pode ser incorporado pelas células em proliferação. Quando incorporado BrdU pode se detectado por anticorpos específicos. O ensaio foi realizado conforme 
orientações do fabricante. Foi adicionado $20 \mathrm{~L}$ de BrdU as células em cultura. As amostras foram incubadas por $2 \mathrm{~h}$ á $37^{\circ} \mathrm{C}\left(5 \% \mathrm{CO}_{2}\right)$. A placa foi centrifugada á $4^{\circ} \mathrm{C}, 6400 \mathrm{rad}, 10 \mathrm{~min}$, “no break". Após aspiração do meio, o DNA foi desnaturado com a adição de Fixdenat, e as amostras foram incubadas $30 \mathrm{~min}$ á temperatura ambiente. Foi adicionado anticorpo antiBrdU conjugado com peroxidase, na diluição 1:100, e as amostras foram incubadas por 90 min á temperatura ambiente. Após lavagens foi adicionado 100 ul da solução substrato. As amostras foram incubadas entre 5 á 30 min. Reação foi parada com adição de $1 \mathrm{M}$ de $\mathrm{H}_{2} \mathrm{SO}_{4}$. Os valores de absorbância foram obtidos no comprimento de onda $450 \mathrm{~nm}$ e fator de correção em $690 \mathrm{~nm}$.

As citocinas presentes no sobrenadante da cultura celular foram detectadas por ELISA de captura. Placas de cultura foram centrifugadas á $4{ }^{\circ} \mathrm{C}, 6400 \mathrm{rad}, 10 \mathrm{~min}$, “no break". O sobrenadante foi transferido para microtubo e armazenado á $-20{ }^{\circ} \mathrm{C}$. Nestas amostras avaliamos a presença de IL-4, IL12 e IFNy. Os reagentes foram comercialmente obtidos e os experimentos foram realizados conforme orientações do fabricante (Peprotech, Cidade do México, México).

Placas de 96 poços (Costar® High binding, Corning) foram tratadas com $100 \mathrm{ng}$ de anticopos de captura (Peprotech), por 16 h á temperatura ambiente. Após lavagens com PBStween $0,05 \%$ os poços foram bloqueados com 300 ul de solução de bloqueio $(1 \mathrm{~h}$ á temperatura ambiente). Após lavagens $100 \mathrm{uL}$ das amostras ou da solução padrão foram adicionadas em cada poço. As placas foram incubadas $2 \mathrm{~h}$ á temperatura ambiente. Após lavagens foi adicionado anticorpo de detecção, na concentração recomendada pelo fabricante. As placas foram incubadas $2 \mathrm{~h}$ á temperatura ambiente. Após lavagens foi adicionado anticorpo secundário conjugado com avidina (1:2.000). As placas foram incubadas por $30 \mathrm{~min}$ á temperatura ambiente, e lavadas com PBS-tween 0,05\%. Foram adicionados $100 \mathrm{ul}$ da solução substrato, ABTS (Sigma). As placas foram incubadas até o desenvolvimento de cor. A leitura da densidade ótica foi realizada no comprimento de onda $405 \mathrm{~nm}$ com fator de correção á $650 \mathrm{~nm}$.

\subsection{Interação das proteínas trecombinantes com ECM e componentes do soro}

A avaliação da interação das proteínas recombinantes com componentes de matriz extracelular e componentes foi realizada por ELISA (BARBOSA et al., 2006). Foram 
empregadas diferentes proteínas de matriz extracelular e proteínas séricas obtidas comercialmente. Como controle foi utilizado BSA, fetuína e gelatina.

Laminina, colágeno tipo IV, colágeno tipo I, fibronectina celular, elastina, componentes do sistema complemento, vitronectina, componentes de matriz extracelular, BSA (controle negativo) e gelatina (controle negativo) foram comercialmente obtidos do fabricante Sigma. Fibrinogênio foi comercialmente obtido do fabricante Invitrogen. Fibronectina plasmática e plasminogênio foram comercialmente obtidos de Merk (New Jersey, N.J., E.U.A.). Os componentes fator $\mathrm{H}$ e C4bp foram respectivamente obtidos dos fabricantes Calbiochem (Darmstadt, Alemanha) e Complement Technology, INC (Texas, T.X., E.U.A.).

Placas de ELISA (Costar® High binding, Corning) de 96 poços foram tratadas com 1 g de cada componente diluído em PBS 1 x. As placas foram incubadas por três horas á 37 ${ }^{\circ} \mathrm{C}$. Os poços foram bloqueados com PBS contendo $10 \%$ de leite desnatado por $18 \mathrm{~h}$. A solução de bloqueio foi descartada e foi adicionado $1 \mathrm{~g}$ de proteína á cada poço. As placas foram mantidas por $2 \mathrm{~h}$ á $37^{\circ} \mathrm{C}$ e lavadas 3 vezes com PBS-tween 0,05\%. Para detecção de proteínas ligantes, foi adicionado anticorpos policlonais homólogos ou anticorpos contra resíduos de histidina (sigma). A diluição de anticorpos policlonais homólogos variou de acordo com a proteína. Foi empregada a diluição cuja densidade ótica foi $1 \mathrm{em}$ experimentos de titulação. Os anticorpos homólogos foram diluídos 1:2.000 para detecção de rLIC11087 e 1:50.000 para detecção de rLIC11228 e rLIC11084.

Quando a detecção da proteína foi realizada por anticorpos policlonais homólogos, foi adicionado, após lavagens, anti-IgG de camundongo conjugado com peroxidase na diluição 1:5.000. Os procedimentos de revelação e leitura da densidade ótica estão descritos no final da seção detecção de anticorpos IgG por ELISA. Para análises estatísticas, a densidade ótica da ligação das proteínas recombinantes aos componentes foi comparada com os controles negativos por Student's t test (bicaudal).

A interferência da estrutura da proteína na ligação á proteínas de matriz e proteínas séricas também foi investigada. As proteínas recombinantes foram fervidas á $100{ }^{\circ} \mathrm{C}$ por 10 min antes de serem adicionadas aos poços.

A afinidade das proteínas aos seus respectivos componentes ligantes foi avaliada variando a concentração de proteína. A densidade ótica obtida foi usada para calcular a constante de dissociação $\left(K_{D}\right)$ (LIN et al., 2009a; PATHIRANA et al., 2006). A equação empregada foi $K_{D}=\left(\mathrm{A}_{\text {máx }}\right.$ [proteína]/A)-[proteína]. A é a absorbância numa dada concentração 
de proteína, $\mathrm{A}_{\text {máx }}$ é a absorbância máxima (equilíbrio), [proteína] é a concentração da proteína e $K_{D}$ é a constante de dissociação para uma dada absorbância numa dada concentração de proteína.

\subsection{Inibição da formação do coágulo de fibrina por rLIC11087}

Foi avaliado a inibição da formação do coágulo de fibrina pela interação de rLIC11087 com fibrinogênio (LIN et al., 2011). 1 g de proteína foi incubado com $1 \mathrm{mg} / \mathrm{mL}$ de fibrinogênio (Invitrogen) $2 \mathrm{~h}$ á $37^{\circ} \mathrm{C} .1 \mathrm{U}$ de trombina (Sigma) foi adicionado ás amostras. As placas foram lidas a cada 5 min em espectrofotômetro (Multiskan FC) no comprimento de onda $600 \mathrm{~nm}$. Como controle negativo foi avaliado a formação do coágulo sem adição de trombina e como controle positivo foi avaliado a formação do coágulo sem a adição de rLIC11087.

\subsection{Interferência da interação entre as proteínas recombinantes e plasminogênio pelo ácido aminocapróico}

Para avaliarmos se a ligação de rLIC11087, rLIC11228 e rLIC11084 ocorre por resíduos de lisina adicionamos o análogo de lisina ácido 6-aminocapróico (Sigma). Placas de 96 poços foram incubadas com $1 \mathrm{~g}$ de proteína recombinante. As placas foram incubadas por $18 \mathrm{~h}$. Os poços foram bloqueados com PBS contendo $10 \%$ de leite desnatado por $2 \mathrm{~h}$. Foi adicionado 1 g de plasminogênio com $2 \mathrm{mM}$ de ácido 6-aminocapróico, e as placas foram incubadas por $2 \mathrm{~h}$ á $37^{\circ} \mathrm{C}$. As placas foram lavadas 3 vezes com PBS-tween $0,05 \%$ e o plasminogênio ligado foi detectado por anticorpos específicos e conjugados com peroxidase (Sigma) na diluição 1:5.000. Os procedimentos de revelação e leitura da densidade ótica estão descritos no final da seção detecção de anticorpos IgG por ELISA.

\subsection{Atividade enzimática de plasmina gerada a partir de plasminogênio ligado ás proteínas recombinante}

Foi avaliada por ELISA a clivagem de um substrato cromógeno por plasmina gerada a partir de plasminogênio ligado as proteínas recombinantes (VIEIRA et al., 2010b). Placas de 96 poços foram incubadas com $1 \mathrm{~g}$ de proteína recombinante. As placas foram incubadas por 
18 h. Os poços foram bloqueados com PBS contendo $10 \%$ de leite desnatado por 2 h. Foi adicionado $1 \mathrm{~g}$ de plasminogênio e as placas foram incubadas por $2 \mathrm{~h}$ á $37^{\circ} \mathrm{C}$. As placas foram lavadas para retirada de plasminogênio não ligado e foi adicionado $4 \mathrm{ng}$ do ativador uPA (ativador de plasminogênio tipo uroquinase). Foi adicionado a cada poço $0,4 \mathrm{mM}$ do substrato cromógeno D-valyl-leucyl-lysine-p-nitroanilide dihydrochloride (Sigma) diluído em PBS. A reação foi mantida por $18 \mathrm{~h}$ á $37{ }^{\circ} \mathrm{C}$ e a densidade ótica das amostras foram avaliadas em espectrofotômetro (Multiskan FC) no comprimento de onda $405 \mathrm{~nm}$. Como controles negativos avaliamos a geração de plasmina com o emprego de como substrato gelatina ou ocultando um dos componentes da reação, substrato, plasminogênio ou ativador.

\subsection{Imunofluorescência para análise da localização celular das proteínas}

A análise da localização das proteínas na superfície de leptospiras foi realizada por imunofluorescência. $10^{9}$ Células de leptospiras cultivadas em meio EMJH por sete dias foram coletadas por centrifugação 6.400 rad por 15 min á $4{ }^{\circ} \mathrm{C}$. O sedimento bacteriano foi lavado por 3 vezes com PBSls e as células foram fixadas com a adição de 0,2 $\mathrm{mL}$ de paraformaldeído $2 \%$. As amostras foram mantidas por $40 \mathrm{~min}$ a $30{ }^{\circ} \mathrm{C}$ e então centrifugadas por $10 \mathrm{~min}, 6.400$ $\mathrm{rad}$, á $4{ }^{\circ} \mathrm{C}$. As amostras foram bloqueadas com PBSls e BSA 5\% por 90 min. As células foram centrifugadas por $10 \mathrm{~min}, 6400 \mathrm{rad}$, á $4{ }^{\circ} \mathrm{C}$ e incubadas com antissoro contendo anticorpos homólogos a proteínas recombinantes diluídos 1:50 em PBSls e BSA 1\%. As amostras foram mantidas $1 \mathrm{~h}$ á $30^{\circ} \mathrm{C}$ e então lavadas por 3 vezes com PBSls. As células incubadas por $45 \mathrm{~min}$ a $30{ }^{\circ} \mathrm{C} \operatorname{com} 200 \mathrm{~L}$ de iodeto de propídio (Sigma) diluído 1:5 e anticorpo secundário diluído 1:50 (Sigma). O anticorpo secundário é conjugado com FITC (fluoresceína isocianetada) e especifico a detecção de anticorpos de camundongos. As amostras foram lavadas por 3 vezes com PBSls e ressuspensas em 25 L de PBSls e uma gota de antifade ProLong® Gold (Invitrogen). As lâminas foram montadas e incubadas por $16 \mathrm{~h}$. As amostras foram avaliadas em microscópio de imunofluorescência confocal LSM 510 META (Carl Zeiss Inc., Oberkochen, Alemanha) do departamento de Parasitologia do instituto Butantan (São Paulo, S.P.). Foi empregado aumento de 600 vezes (FITC, excitação em $488 \mathrm{~nm}$, emissão 500-550 nm; Iodeto de propídeo, excitação 543 nm, emissão 612-619 $\mathrm{nm})$. 


\subsection{Condições de infecção de hamster}

Hamsters machos foram infectados via intraperitoneal com $1 \times 10^{4}$ L. interrogans sv. Kennewicki linhagem Pomona Fromm virulenta. Os animais foram sangrados via plexo retroorbital após o desenvolvimento dos sintomas (5 dias após infecção). Os soros destes animais foram empregados nos experimentos de reavidade de anticorpos e proteínas recombiantes. Os animais foram diagnosticados com leptospirose através de MAT. O protocolo de experimentação foi aprovado pelo comitê de ética em experimentação animal da Faculdade de Medicina Veterinária da Universidade de São Paulo.

\subsection{Teste de microaglutinação}

O ensaio de MAT foi realizado conforme descrito por Faine et al., 1999. Foi empregado 22 sorovares como antígeno: Andaman, Australis, Autumnalis, Bataviae, Butembo, Canicola, Castellonis, Celledoni, Copenhageni, Cynopteri, Djasiman, Grippotyphosa, Hebdomadis, Icterohaemorrhagiae, Javanica, Panama, Patoc Pomona, Pyrogenes, Shermani, Tarassovi e Wolffi. Todas as linhagens foram mantidas em meio liquido EMJH á $29{ }^{\circ} \mathrm{C}$. Foi considerado o sorovar predominante o que apresentou aglutinação superior á 50\%. Foram consideradas positivas amostras em que foi observado soroconversão, e negativas as amostras que não foi observada aglutinação em nenhum dos sorovares.

\subsection{Detecção de anticorpos no soro de pacientes e animais infectados}

A avaliação da reatividade das proteínas recombinantes com anticorpos presentes no soro de pacientes ou em soro de animais infectados foi feita por ELISA (OLIVEIRA et al., 2008). As amostras de soro de paciente pertencem a soroteca do Instituto Adolfo Lutz São Paulo e foram cedidas pela Dra. Eliete C. Romero. O diagnóstico destes pacientes foi confirmado por MAT.

$250 \mathrm{ng}$ de proteína recombinante foram imobilizadas em placas de 96 poços. As placas foram lavadas e posteriormente bloqueadas com leite 10\% em PBS-T. Amostras de soro de pacientes ou soro de animais infectados experimentalmente previamente adsorvidas em extrato de E.coli 10\% e BSA 3\% (na diluição 1:100) foram adicionadas aos poços. As placas foram lavadas e os anticorpos ligados foram detectados com anti-IgG humano conjugado com 
peroxidase (Sigma) ou anti-IgG hamster conjugado com peroxidase (Sigma). A diluição empregada foi 1:5.000. A reação foi revelada como anteriormente descrito no procedimento de titulação dos soros imunes. Cada amostra de soro foi avaliada em duplicata.

Os valores de corte para avaliação dos respondedores (cutoff) foram calculados a partir da média da densidade ótica obtida com a reatividade de soro de doadores ou animais não infectados mais três vezes o valor do desvio padrão destes valores. As amostras de soro de doadores saudáveis foram obtidas comercialmente (Sigma) e de oito amostras de hamsters não infectados.

\subsection{Imunização de hamsters e avaliação do perfil protetor de rLIC11084}

Hamsters são modelos de infecção para leptospirose. Esses animais são altamente suscetíveis e desenvolve infecção similar a infecção severa em humanos (HAAKE, 2006). Para avaliação do perfil protetor de rLIC11084 hamsters macho foram imunizados com rLIC11084 e submetidos a desafio letal com a cepa virulenta $L$. interrogans sv. Kennewicki linhagem Pomona Fromm. Os animais foram imunizados subcutaneamente no dorso com 50 $\mathrm{g}$ de proteína recombinante adsorvida em $10 \%$ ( $\mathrm{vol} / \mathrm{vol})$ de Alhydrogel $\left[\begin{array}{lll}2 \% & \mathrm{Al}(\mathrm{OH})_{3}\end{array}\right]$ (Brenntag Biosector). O grupos experimentais foram compostos por 10 animais, e incluíram controle positivo, animais imunizados com bacterina, e controle negativo, animais imunizados apenas com PBS. Os animais foram imunizados com duas doses no intervalo de duas semanas. Antes de cada imunização os animais foram sangrados via plexo retro-orbital e a avaliação dos soros imunes foi realizada como descrito anteriormente na seção detecção de anticorpos IgG por ELISA.

Brevemente, a proteína recombinante, $250 \mathrm{ng}$ por poço, foi imobilizada em placas de 96 poços Costar ${ }^{\circledR}$ (Corning). Após lavagens foi adicionada a solução de bloqueio, PBS-T com $10 \%$ de leite desnatado, e as placas foram mantidas por $2 \mathrm{~h}$ á $37{ }^{\circ} \mathrm{C}$. A solução de bloqueio foi descartada e os soros dos animais imunes, diluídos seriadamente na solução de adsorção, foram adicionados. Após incubação de $1 \mathrm{~h}$, as placas foram lavadas e então foi adicionado e anti-IgG hamster conjugado com peroxidase (Sigma) na diluição 1:5.000. A reação foi revelada como anteriormente descrito no procedimento de titulação dos soros imunes.

A bacterina foi preparada conforme descrito por Silva et al., 2007. $10^{9}$ células de $L$. interrogans sv. Kennewicki linhagem Pomona Fromm virulenta foram coletadas por 
centrifugação, 20 min á 8.000 rad á temperatura ambiente. O sedimento foi lavado duas vezes com PBS acrescido de $5 \mathrm{mM}$ de $\mathrm{MgCl} 2$ e então ressuspenso em PBS. As células foram inativadas por calor, $20 \mathrm{~min}$ á $56^{\circ} \mathrm{C}$, e armazenadas á $-20^{\circ} \mathrm{C}$.

15 dias após a segunda dose, os animais foram inoculados via intraperitonial com 200 $\mathrm{L}$ de PBS contendo a $\mathrm{DL}_{50}$ de $L$. interrogans sv. Kennewicki linhagem Pomona Fromm. O cálculo da $\mathrm{DL}_{50}$ foi feito inoculando animais com diluições seriadas, de ordem 10, desta cepa. As doses variaram de $10^{9}$ á $10^{0}$ leptospiras por mL. Quatro animais foram infectados para cada dose. Os animais foram observados 2 vezes por dia entre os dias 21 e 28 . Foi considerada a $\mathrm{DL}_{50}$ a dose que ocasionou a morte de 50\% dos animais. A DL50 para o primeiro experimento foi $2,76 \times 10^{3}$ e para o segundo foi $2,5 \times 10^{3}$ leptospiras.

Os animais desafiados foram observados por 21 dias. Após este tempo, o sangue dos animais sobreviventes foi coletado via punção cardíaca. Os rins foram coletados, macerados, resuspensos em solução salina (diluição 1:10 e 1:100) e então cultivado em meio EMJH modificado e semi-sólido á $28{ }^{\circ} \mathrm{C}$ para avaliação da presença de leptospiras. $\mathrm{O}$ crescimento foi monitorado por 6 semanas.

As análises estatísticas de sobrevivência foram realizadas pelo programa GraphPad Prism versão 3.00, utilizando o método Kaplan-Meier (Kaplan e Meier, 1958). O valor P $<0,05$ foi considerado estatisticamente significante. 


\section{RESULTADOS E DISCUSSÃO}

\subsection{Características preditas das proteínas que levaram a seleção dos genes}

O estudo de proteínas de membrana externa é importante para a identificação de novos alvos vacinais, desenvolvimento de novos métodos diagnósticos e para a elucidação dos mecanismos de patogênese. $O$ sequenciamento genomico de L.interogans levou a identificação de 263 genes que codificam para supostas proteínas de membrana, sendo 250 destas com funções desconhecidas (NASCIMENTO et al., 2004a).

Baseado na análise do genoma por bioinformática, os genes LIC11221, LIC11087, LIC11228 e LIC11084 identificados e escolhidos para serem estudados visto que codificam para preditas proteínas hipotéticas de membrana externa.

Com a análise destes genes pelos programas PSORT e Cello foi constatado que LIC11121, LIC11087 e LIC11228 codificam para proteínas que apresentaram probabilidade de estarem localizadas na membrana externa (NAKAI; KANEHISA, 1991; YU et al., 2004, 2006). A proteína codificada por LIC11084 foi predita como uma proteína de membrana interna pelo programa PSORT e como uma proteína de membrana externa pelo programa Cello.

A probabilidade de lipidação ou exportação destas proteínas para membrana foi avaliada pela predição de peptídeos sinais pelos programas Signal P e LipoP (JUNCKER et al., 2003; PETERSEN et al., 2011). O método LipoP pode predizer lipoproteínas de bactérias gram-negativas e seu peptídeo sinal de clivagem baseando-se nos modelos hidden Markov (HMM) ou Neural networks (JUNCKER et al., 2003; SETUBAL et al., 2006). Ele é capaz de classificar a sequencia $\mathrm{N}$-terminal de proteínas quanto á presença e a ausência do peptídeo sinal e do ponto de clivagem. O programa possibilita a distinção entre lipoproteínas, que são proteínas com peptídeo sinal e sítio de clivagem para enzima peptidase sinal II (SpII), proteínas com sítio de clivagem para enzima peptidase sinal I (SpI), e proteínas citoplasmáticas ou transmembrana que não possuem peptídeo sinal.

Pontos de clivagem foram identificados em todas as proteínas pelo programa Signal P. A proteína codificada por LIC11084 pode ser uma lipoproteína. Além da predição de aminoácidos que compõe a região do peptídeo sinal foi identificado sítio de clivagem para enzima SpII com a análise da sequencia pelo programa LipoP, sugerindo lipidação. 
Analisando os genes LIC11121 e LIC11228 por este programa, aminoácidos que compõe a região do peptídeo sinal e o sitio de clivagem da enzima SpI foram identificados. Não foi identificado nenhum sítio de clivagem na proteína codificada pelo gene LIC11087, porém este gene foi mantido no estudo devido resultados obtidos nos programa PSORT e SMART.

O programa SMART prediz domínios transmembrana pelo servidor público THMM (LETUNIC et al., 2012; SCHULTZ et al., 1998). A submissão das CDS neste programa resultou na predição de regiões transmembrana nas proteínas codificadas por LIC11121, LIC11087 e LIC11084. Apesar de não terem sido identificadas preditas regiões transmembrana na CDS LIC11228 a predita localização desta hipotética proteína na membrana foi sustentada pelos outros dados obtidos com a análise de bioinformática. A Tabela 2 sumariza os dados obtidos por análises de bioinformática.

Domínios conservados nas CDS foram investigados pelo programa PFAM (FINN et al., 2006; SONNHAMMER et al., 1997). Nenhum domínio conservado foi predito para LIC11087, LIC11121 e LIC11228. Na proteína codificada por LIC11084 foi identificado um domínio da proteína P22 (proteína capsular de bacteriófagos), porém este resultado foi dado como insignificante pelo programa de predição.

Tabela 2- Dados obtidos por análises de bioinformática

\begin{tabular}{ccccc}
\hline \multirow{2}{*}{ Gene ID } & \multicolumn{2}{c}{ Sinal de clivagem e de Lipidação } & \multicolumn{2}{c}{ Domínios e localização predita } \\
& LipoP & Signal P & PFAM & SMART \\
\hline LIC11121 & SpI & Sinal de clivagem (aa: 20-21) & ND & Transmembrana (aa:7-29) \\
LIC11087 & ND & Sinal de clivagem (aa: 24-25) & ND & Transmembrana (aa:7-26 ) \\
LIC11228 & SpI & Sinal de clivagem (aa: 27-28) & ND & ND \\
LIC11084 & SpII & Sinal de clivagem (aa: 27-28) & P22 & Transmembrana (aa:13-35) \\
\hline
\end{tabular}

Notas: Gene ID: Identificação do gene no genoma de L.interrogans sorovar Copenhageni; abreviações: aa- aminoácidos; ND- nada identificado.

Uma das características buscada em antígenos contra leptospirose é a sua conservação. Assim as proteínas codificadas pelos genes em estudo foram analisadas quanto a presença e similaridade com sequencias depositadas no NCBI pela ferramenta BLAST (ALTSCHUL et al., 1990, 1997). 
Todas as proteínas demonstraram similaridade com proteínas hipotéticas de $L$. interrogans sorovar Lai linhagens 56601 e IPAV e L. noguchii linhagem 2006001870. As proteínas codificadas por LIC11087 e LIC11228 apresentaram similaridade com outras espécies patogênicas do gênero Leptospira, L. santarosai linhagem 2000030832, L. weilii linhagem 2006001855, L. borgpetersenii sorovar Hardjo-bovis linhagens L550 e JB197.

Baixa identidade foi atribuída á espécies saprófitas e intermediárias. As proteínas codificadas por LIC11087, LIC11228 e LIC11121 apresentaram baixa identidade com sequencias de L. biflexa sorovar Patoc linhagens Patoc 1 (Ames) e Patoc 1 (Paris) e $L$. licerasiae sorovar Varillal linhagem MMD0835. LIC11084 apresentou baixa similaridade apenas com a espécie intermediária L. licerasiae sorovar Varillal linhagem MMD0835. Apenas a proteína hipotética de LIC11228 apresentou baixa similaridade, 22\% de identidade, com proteínas de Leptonema illini DSM 21528, bactérias não patogênicas pertencentes á família Leptospiraceae.

Os alinhamentos realizados com sequencias obtidas no banco de dados do NCBI e montados pelo programa Clustal podem ser visualizados no apêndice A.

\subsection{Presença dos genes, seus transcritos e proteínas em espécies do gênero Leptospira}

Para corroborar a análise in silico de conservação, foi avaliada a amplificação dos genes LIC11087, LIC11228 e LIC11084 a partir, do DNA genomico, de diferentes espécies do gênero Leptospira.

Os genes LIC11228 e LIC11087 foram amplificados em todas as espécies patogênicas L. interrogans, L. borgpetersenii, L. kirschneri, L. santarosai, L noguchii. O gene LIC11084 foi amplificado apenas nos sorovars da espécie L. interrogans. Apenas o gene LIC11228 foi amplificado a partir do DNA genomico de L. biflexa (Figura 2). 
Figura 2- Amplificação dos genes em estudo de espécies do gênero Leptospira

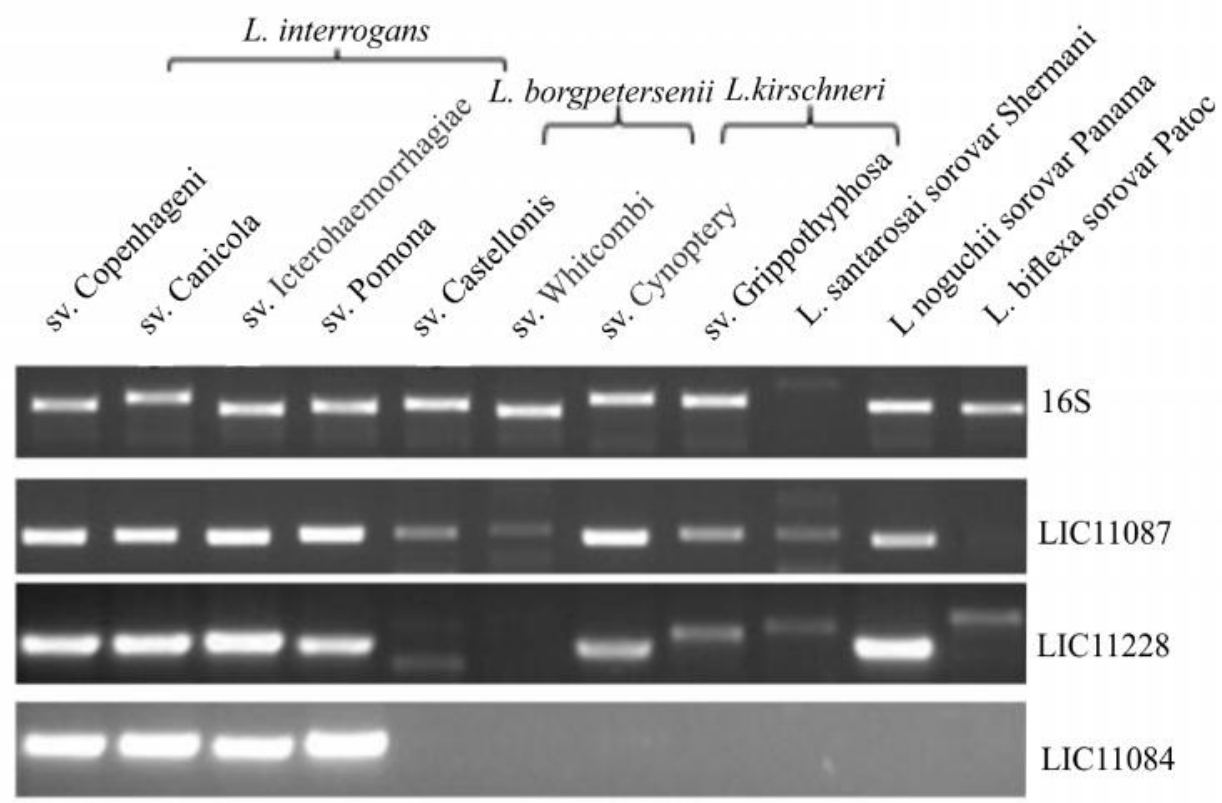

Os genes foram amplificados com os oligonucleotídeos iniciadores, específicos á LIC11087, LIC11228 e LIC11084, a partir do DNA genômico de espécies patogênicas L. interrogans, L. borgpetersenii, L. kirschneri, $L$. santarosai, L noguchii e da espécie saprófita L.biflexa.

Estes resultados corroboram os dados gerados por análise de bioinformática. $\mathrm{O}$ gene mais conservado é LIC11228, e a amplificação de LIC11084 e LIC11087 de espécies patogênicas pode sugerir que eles estão relacionados com a patogênese bacteriana. Estudos complementares são necessários para confirmar estas hipóteses.

Um gene de L. biflexa sorovar Patoc 1 apresenta baixa similaridade com o gene LIC11087, possivelmente devido a isso não foi possível a amplificação deste gene com os oligonucleotídeos empregados.

Apesar de apresentar alta identidade de LIC11228 com genes de L. borgpetersenii sorovar Hardjo-bovis linhagens JB197 e L550 nenhum gene com tamanho esperado foi amplificado. Isto pode ter ocorrido por este gene ser polimórfico nas espécies de $L$. borgpetersenii sorovar Castellonis linhagem Castellon 3 e sorovar Whitcombi linhagem Whitcombi.

Também foi investigada a presença de transcritos correspondente aos genes em diferentes espécies. Oligonucleotídeos iniciadores específicos foram empregados na tentativa 
de amplificação dos genes. Porém foi constatado contaminação das amostras nas reações sem transcriptase reversa. Isto tornou os dados inconclusivos.

Outra abordagem experimental empregada para a avaliação dessas CDS foi a identificação de proteínas por immunoblotting. Nestes experimentos os extratos proteicos de leptospira foram submetidos a eletroforese e transferidos para membrana de nitrocelulose.

Para análise da expressão da proteína nativa, extratos proteicos de diferentes espécies foram submetidos a eletroforese em gel de poliacrilamida. As proteínas foram transferidas para membrana de nitrocelulose e identificadas com anticorpos policlonais contra rLIC11087, rLIC11228 e rLIC11084.

Nenhuma banda correspondente as proteínas em estudo foi identificada. Isto pode ser atribuido ao baixo número de cópias por células das proteínas (MALMSTROM et al., 2009; VIEIRA et al., 2009).

\subsection{Clonagem e expressão das proteínas recombinantes}

As sequencias de DNA correspondentes aos genes LIC11121, LIC11087, LIC11228 e LIC11084 foram amplificadas a partir do DNA genômico extraído da cultura de $L$. interrogans sorovar Copenhageni pela técnica de PCR. Os produtos de PCR obtidos foram analisados por eletroforese em gel de agarose $1 \%$ e apresentaram o tamanho esperado (Figura $3 \mathrm{~A})$.

Os insertos de DNA obtidos através da reação de PCR foram utilizados para clonagem em vetor pGEM-T Easy (Promega). Esse é um vetor linearizado, com uma timidina $3^{\prime}$ terminal em ambas as extremidades, o que permite a ligação dos produtos de PCR e evita recircularização do vetor. Esse vetor contém ainda promotores T7 e SP6, e o sítio de múltipla clonagem interrompendo a região codificadora da enzima $\beta$-galactosidase. Essa inativação permite a identificação dos clones recombinantes por seleção azul/branco em placas contendo LB/Amp, IPTG e X-Gal.

Após transformação em bactérias competentes, os clones recombinantes foram préselecionados pela coloração apresentada e a confirmação da clonagem seguiu por amplificação dos genes de interesse com iniciadores específicos. A reação de amplificação foi realizada a partir de 2 ul de colônias pré selecionadas.

Os insertos foram removidos dos plasmídeos recombinantes (pGEM-T Easy/inserto) através de ensaio de restrição utilizando as enzimas XhoI/HindIII para os vetores pGEM 
LIC11087 e pGEM LIC11221, BamHI/ KpnI para o vetor pGEM LIC11228 e BamHI/HindIII para o vetor pGEM LIC11084. Os insertos liberado foram então subclonados no vetor de expressão pAE (RAMOS et al., 2004). A pré-seleção de clones recombinantes ocorreu previamente por amplificação com oligonucleotídeos específicos, como descrito anteriormente. Realizamos um ensaio de restrição utilizando as respectivas enzimas de restrição, para certificação da presença de inserto (Figura 3B). Pode ser evidenciada a liberação do inserto por análise de restrição para todos os clones recombinantes. Nenhuma mutação foi constatada após sequenciamento, teste que também evidenciou que os genes estão em fase de leitura (Figura 3C). 
Figura 3- Avaliação da clonagem dos genes no vetor pAE por análise de restrição e sequenciamento
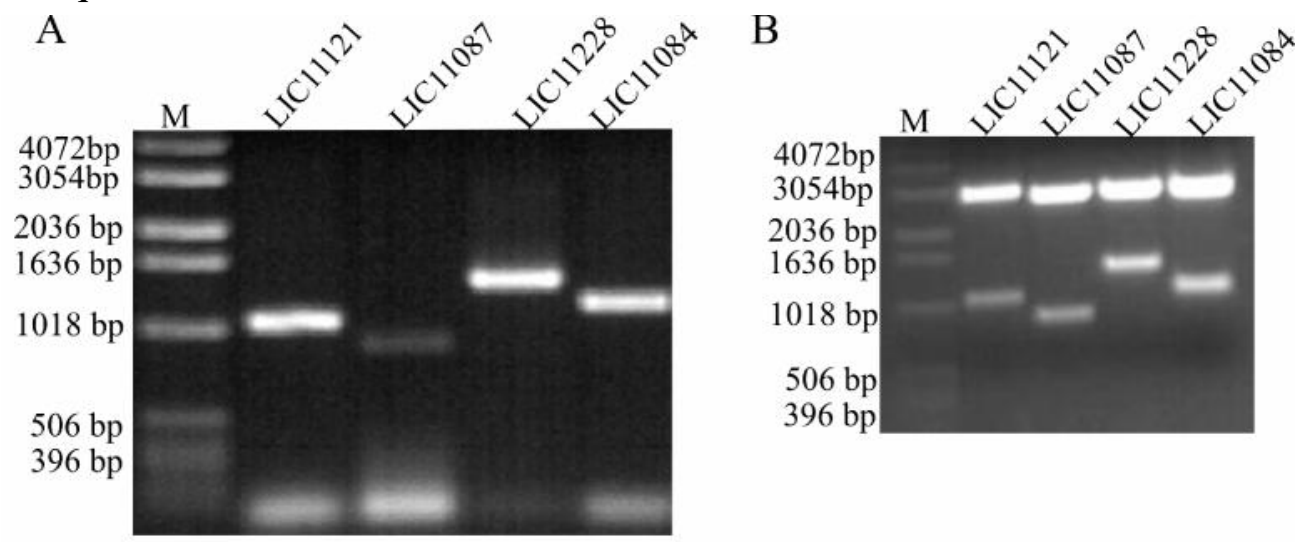

C

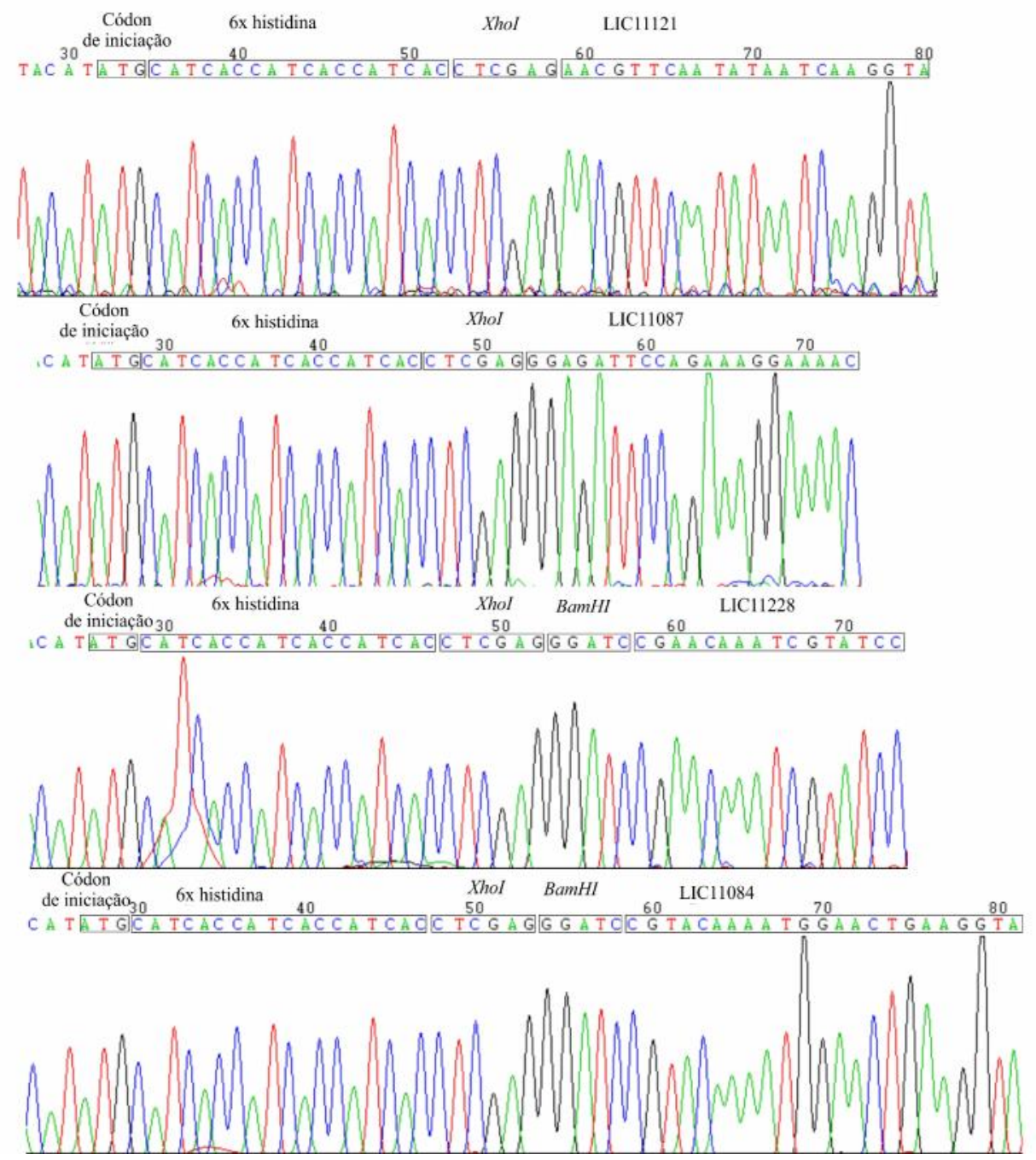

(A) Insertos de DNA obtido por PCR e analisados em gel de agarose 1\%. M (marcador de massa molecular $1 \mathrm{~Kb}$ Plus DNA Ladder), LIC11121(1Kb), LIC11087 (0,8 Kb), LIC11228 (1,4 Kb), LIC11084 (1,1kb). (B) Análise de restrição dos clones recombinantes (pAE/inserto). As construções foram digeridas com suas respectivas enzimas de restrição. M (marcador de massa molecular $1 \mathrm{~Kb}$ Plus DNA Ladder), LIC11221 (pAE/LIC11121), LIC11087 (pAE/LIC11087), LIC11228 (pAE/LIC11228), LIC11084 (pAE/LIC11084).Tamanho do vetor pAE 2.8 Kb. (C) Cromatograma gerado com o sequenciamento das construções. Nucleotídeos sublinhados demonstram códon de iniciação, 6 resíduos de histidina, sítio de restrição e oligonucleotídeos iniciadores. 
Para expressão das proteínas recombinantes foram empregadas as cepas de expressão E. coli BL21 (SI), E. coli BL21 (DE3) e E. coli BL21 Star (DE3) pLysS. As bactérias foram transformadas com os vetores contendo os genes de interesse e a indução da expressão das proteínas foi realizada com a adição de $\mathrm{NaCl}$ ou IPTG a cultura.

As cepas de expressão foram transformadas e induzidas com diferentes concentrações de indutor. As concentrações utilizadas foram 75, 150 e $300 \mathrm{mM}$ quando o indutor foi $\mathrm{NaCl}$ (E.coli BL21 SI), e 0,25; 0,5 e $1 \mathrm{mM}$ para as cepas de E. coli BL21 (DE3), na qual indutor foi o IPTG . Após indução, as bactérias foram lisadas e as frações proteicas obtidas analisadas por SDS-PAGE 12\% (Figura 4).

As proteínas rLIC11121, rLIC11087 e rLIC11228 foram expressas na forma de corpúsculos de inclusão e rLIC11084 foi obtida na forma solúvel. A cepa E. coli DE3 foi escolhida para expressão de rLIC11087 e E. coli BL21 (SI) para expressão de rLIC11084 e rLIC11228. Devido problemas no processo de purificação empregamos tanto E. coli BL21 (SI) como E. coli DE3 para expressão de rLIC11121 (Figura4). 
Figura 4- Análise da expressão das proteínas recombinantes por eletroforese em SDS-PAGE.

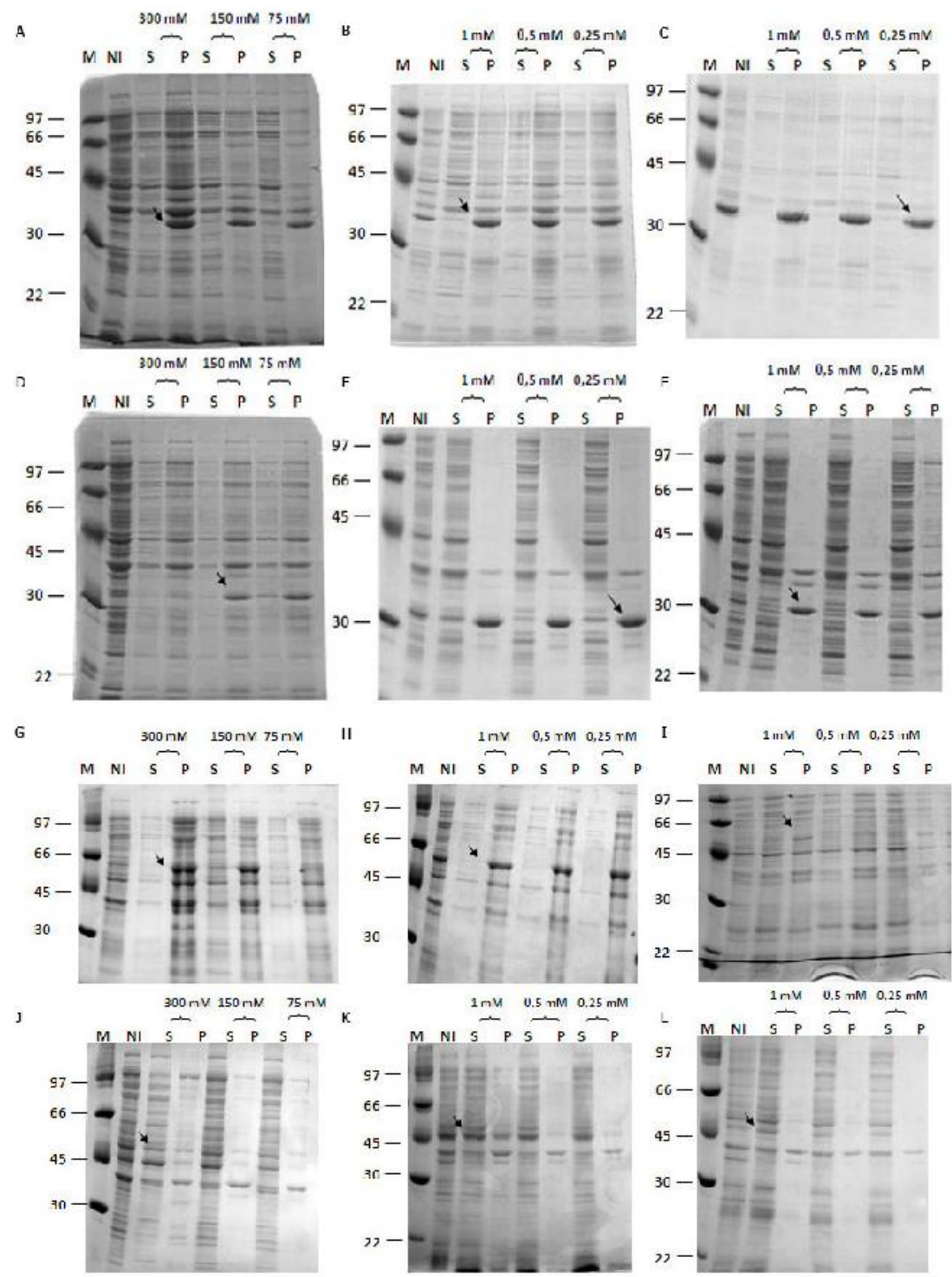

Análise da expressão das proteínas recombinantes por eletroforese em SDS-PAGE. (A,B,C) rLIC11121 expressa respectivamente por E. coli BL21 (SI), E. coli BL21 (DE3) e E. coli BL21 Star (DE3) pLysS ; (D,E,F) rLIC11087 expressa respectivamente por E. coli BL21 (SI), E. coli BL21 (DE3) e E. coli BL21 Star (DE3) pLysS; (G,H,I) rLIC11228 expressa respectivamente por E. coli BL21 (SI), E. coli BL21 (DE3) e E. coli BL21 Star (DE3) pLysS; (J,K,L) rLIC11084 expressa respectivamente por E. coli BL21 (SI), E. coli BL21 (DE3) e E. coli BL21 Star (DE3) pLysS. (M) Padrão de massa molecular (KDa). (NI) extrato não induzido. (I) extrato induzido total. (S) fração solúvel. (P) fração insolúvel. As concentrações dos indutores utilizados estão destacadas acima da descrição das frações. Os indutores utilizados foram $\mathrm{NaCl}$ para $E$. coli BL21 SI, e IPTG para E. coli BL21 DE3 e E. coli BL21 Star DE3 pLysS). Setas indicam a possível expressão das proteínas.

Bandas correspondentes às proteínas recombinantes haviam sido encontradas nas frações antecedentes ao processo de indução. A confirmação da expressão das proteínas de interesse foi realizada pela imunodetecção dos resíduos de histidina (Figura 5). Todas as 
proteínas recombinantes foram reconhecidas por anticorpos monoclonais contra os seis resíduos de histidina.

Figura 5- Identificação das proteínas recombinantes por imunoblotting com o anticorpo monoclonal anti-6X histidina.
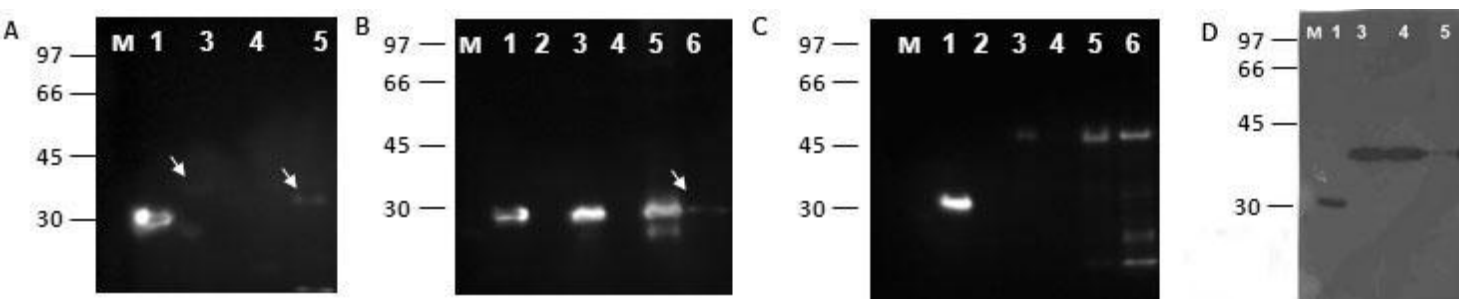

(A)rLIC11221; (B) rLIC11087; (C) rLIC11228;(D) rLIC11084. M, Marcador; 1, Controle positivos, rLipL32; 2 Extrato total da bactéria não transformada; 3, bactéria transformada mas não induzida; 4, fração solúvel da cultura induzida; 5 , fração insolúvel da cultura induzida; 6, proteína purificada. Setas brancas auxiliam na identificação de bandas com fraca marcação. A quimiluminescência das figuras A, B e C foi detectada em fotodocumentador (pro 2200, gel logic carestream) e na figura D por sensibilização de filme de raio X.

As sequencias de aminoácido das proteínas recombinantes foram submetidas ao programa ProtParam (disponível em http://www.expasy.org/tools/protparam.html) para análise do ponto isoelétrico e da massa molecular (GASTEIGER et al., 2003). Os resultados das análises estão descritos na Tabela 3.

Tabela 3- Massa molecular e ponto isoelétrico teórico (pI) das proteínas codificadas pelos genes selecionados

\begin{tabular}{lll}
\hline Proteínas & $\begin{array}{l}\text { Massa } \\
\text { molecular }\end{array}$ & $\mathrm{pI}$ \\
\hline rLIC11121 & $37.3 \mathrm{KDa}$ & 8.45 \\
rLIC11087 & $30 \mathrm{KDa}$ & 5.77 \\
rLIC11228 & $52.8 \mathrm{KDa}$ & 7.7 \\
rLIC11084 & $40.7 \mathrm{KDa}$ & 7.7 \\
\hline
\end{tabular}

Nota: LIC- abreviação de L. interrogans sorovar Copenhageni. Dados obtidos submetendo sequencia de aminoácidos ao servidor Expasy (http://www.pdg.cnb.uam.es/peptide-mass.html). 


\subsection{Purificação das proteínas recombinantes e análise da estrutura secundária}

$\mathrm{O}$ vetor de expressão pAE adiciona 6 resíduos de histidina na porção $\mathrm{N}$-terminal das proteínas recombinantes. Assim estas proteínas podem ser purificadas por cromatografia de afinidade ao metal. Diferentes protocolos de purificação por cromatografia de afinidade ao metal foram testados para a purificação das proteínas deste estudo. Após o processo de purificação, as proteínas submetidas a eletroforese em gel, possibilitando assim a análise do material purificado quanto a pureza, concentração e estabilidade ou degradação. A presença de estruturas secundárias foi avaliada submetendo as proteínas purificadas à análise de dicroísmo circular (JOHNSON, 1990).

O estudo da estrutura secundária das proteínas por dicroísmo circular é baseado no fato de que moléculas com centros assimétricos absorvem luz circularmente polarizada para a direita, isso provoca um desvio no ângulo da polarização da luz incidente para a direita ou para a esquerda. Esse desvio é conhecido como elipticidade e é medido por um polarímetro (KELLY et al., 2005). Estas informações geram um espectro, que é característico de elementos estruturais específicos, como ligações amida, resíduos aromáticos e pontes dissulfeto (GREENFIELD, 2006).

A proteína rLIC11084 foi obtida na forma solúvel e purificada no sistema ÄKTA Prime plus (GE Healthcare) (Figura 6A). Como observado no gel de poliacrilamida, esta proteína teve rendimento de aproximadamente $30 \mathrm{mg}$ por litro de cultura induzida e não foi constatada a presença de proteínas contaminantes ao final do procedimento de purificação (Figura 6A). Ao final do processo de purificação esta proteína foi dialisada em tampão 10 $\mathrm{mM}$ tris $\mathrm{pH} 12,20 \mathrm{mM} \mathrm{NaCl}$ e $0,01 \%$ de glicina, condições em que a proteína ficou mais estavel, e foi estocada a $-20{ }^{\circ} \mathrm{C}$.

O espectro resultante da análise desta proteína por dicroísmo circular apresentou elipcidade mínima nos comprimentos de onda 208-220 nm, e elipcidade máxima em 194 nm. A alta voltagem do tampão inviabilizou leituras em comprimentos de ondas inferiores a 194 nm (Figura 6B).

Os valores de elipcidade obtidos no espectro diferiram aos descritos na literatura (KELLY et al., 2005). Isto pode ser um indicio de que esta proteína não está estruturada e que o espectro gerado pode ser ruído provocado pelo tampão durante a leitura das amostras (Figura 6B). 
Figura 6- Análise da purificação de rLIC11084 por SDS-PAGE e espectro gerado por análise das proteínas por dicroismo circular.

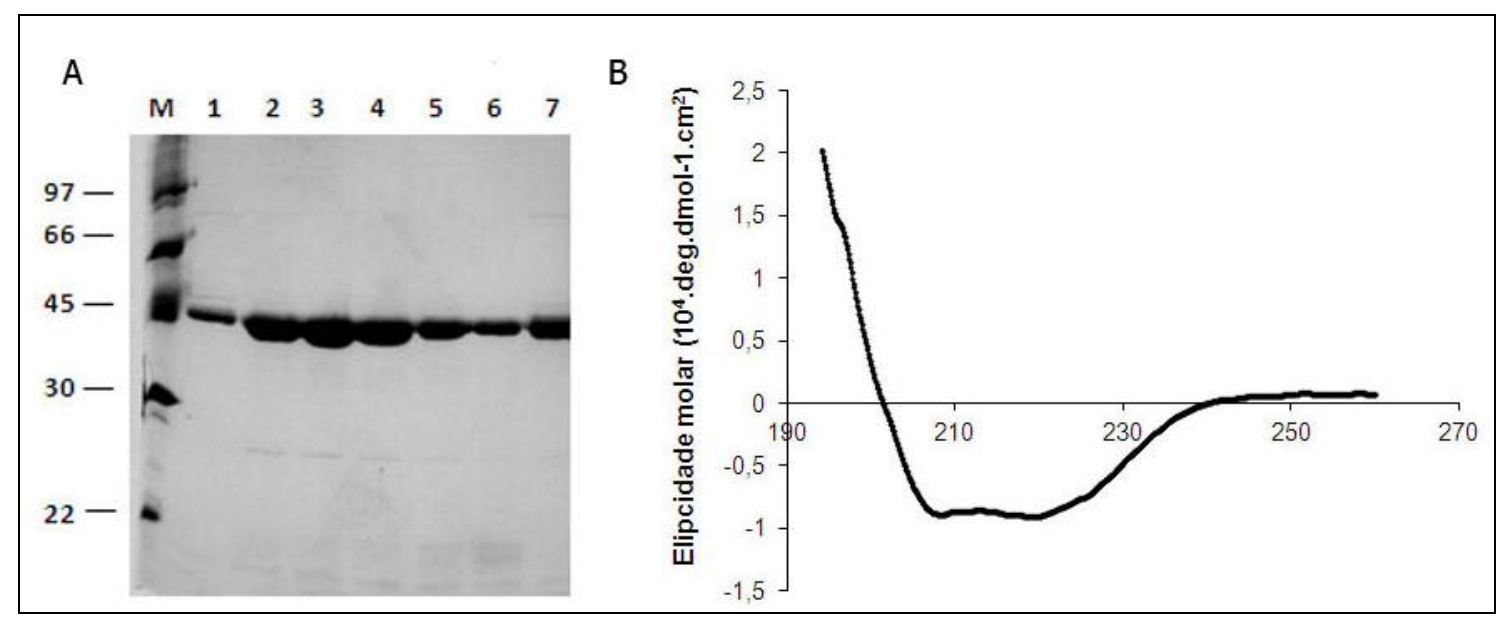

(A) SDS-PAGE de proteína purificada pelo sistema AKTA-Prime. M, padrão de massa molecular (KDa); 1-7 frações eluídas. (B) Espectro gerado com análise de dicroísmo circular de rLIC11084.

rLIC11087 e rLIC11228 foram obtidas com um rendimento aproximado de $6 \mathrm{mg} / \mathrm{Litro}$ de cultura induzida essas proteínas ficaram mais estáveis em tampões com pH12.

O rendimento de rLIC11087 foi similar tanto para purificação na bancada quanto na purificação pelo aparelho ÄKTA Prime plus (Figura 7 A e B). Análise de dicroísmo circular evidenciou a presença de estrutura secundária. A proteína demonstrou estrutura predominante de $\alpha$-helice com elipcidade mínima entre 210 e $220 \mathrm{~nm}$ e elipcidade máxima em 192nm (Figura 7 C). A proteína é composta por $62,6 \%$ de estrutura $\alpha$-hélice e 3,79\% de folha beta pregueada segundo predição do programa $\mathrm{K}_{2} \mathrm{D}_{2}$ (PEREZ-IRATXETA; NAVARRO, 2008). 
Figura 7- Análise da purificação de rLIC11087 por SDS-PAGE e espectro gerado por análise das proteínas por dicroismo circular.

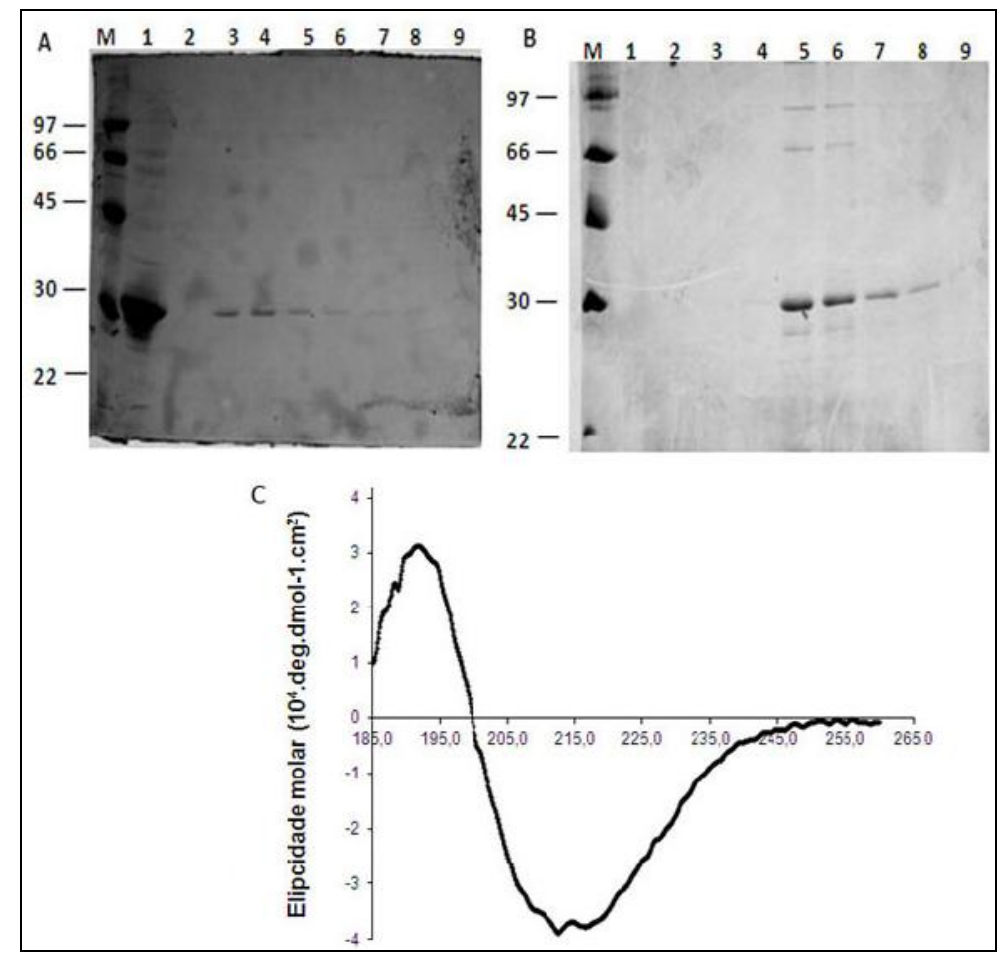

(A) SDS-PAGE de proteína purificada pelo sistema AKTA-Prime. M, padrão de massa molecular (KDa); 1, fração induzida antes da purificação; 2-9, frações eluídas. (B) SDS-PAGE de proteína purificada em bancada pelo método de renaturação em coluna. M, marcador; 1-9, frações eluídas. (C) Espectro gerado pela análise de dicroísmo circular de rLIC11087.

Tentativas de purificação da proteína rLIC11228 pelo sistema ÄKTA Prime plus não foram bem sucedidas. Neste método a proteína foi obtida em baixa concentração e preciptou em etapas posteriores de purificação (Figura 8A). Foi possível a purificação da proteína pelo método de purificação por renaturação em 2L de tampão (Figura 8B).

A análise da estrutura desta proteína por dicroísmo circular resultou num espectro não característico de estruturas descritas (Figura 8C). A elicidade molar mínima foi atingida em $215 \mathrm{~nm}$. Isto pode ser atribuído á problemas metodológicos, visto que a alta voltagem, ocasionada pela osmolaridade do tampão, impossibilitou leituras em comprimentos de onda inferior á $200 \mathrm{~nm}$. 
Figura 8- Análise da purificação de rLIC11228 por SDS-PAGE e espectro gerado por análise das proteínas por dicroismo circular.

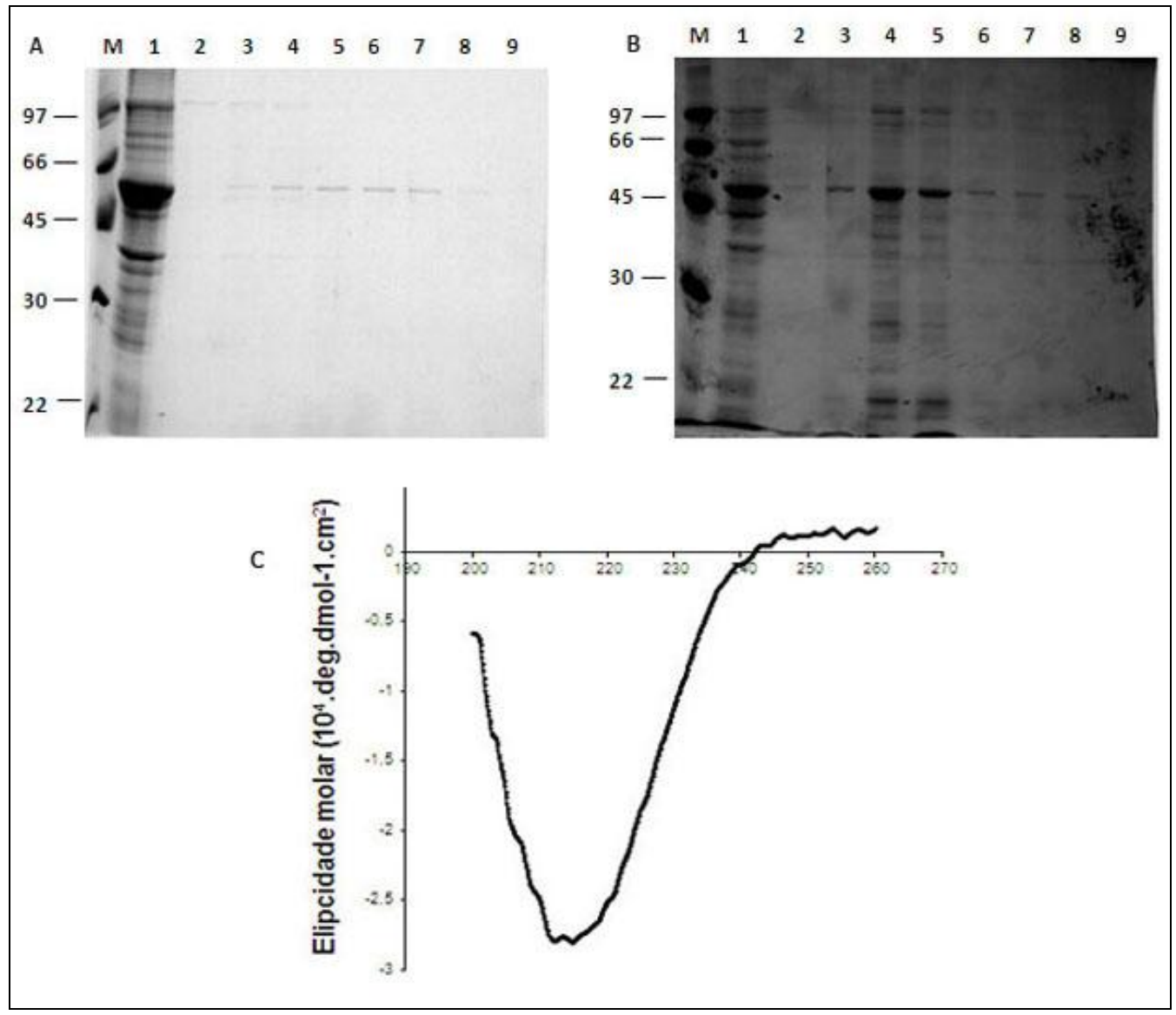

(A) SDS-PAGE de proteína purificada pelo sistema AKTA-Prime. M, padrão de massa molecular (KDa); 1, fração induzida antes da purificação; 2-9, frações eluídas. (B) SDS-PAGE de proteína purificada em bancada pelo método de renaturação em coluna. M, marcador; 1, fração induzida antes da purificação; 2-9, frações eluídas. (C) Espectro gerado pela análise de de rLIC11228 por dicroísmo circular.

A proteína rLIC11121 foi obtida em baixa concentração, $1 \mathrm{~mL}$ na concentração de $5 \mathrm{ug} / \mathrm{mL}$, e por isso excluída do estudo (Figura 9). As tentativas de purificação compreenderam purificação em sistema ÄKTAPrime plus e purificação em bancada. Os protocolos de purificação diferiram na forma de renaturação, renaturação em $2 \mathrm{~L}$ de tampão ou com gradiente de ureia na coluna, e com a adição de agentes para o aumento da estabilidade da proteína (glicerol $10 \%$ e $0,1 \%$ triton x100) (Figura 9). 
Figura 9- SDS-PAGE para análise da purificação de rLIC11121 (37 KDa).

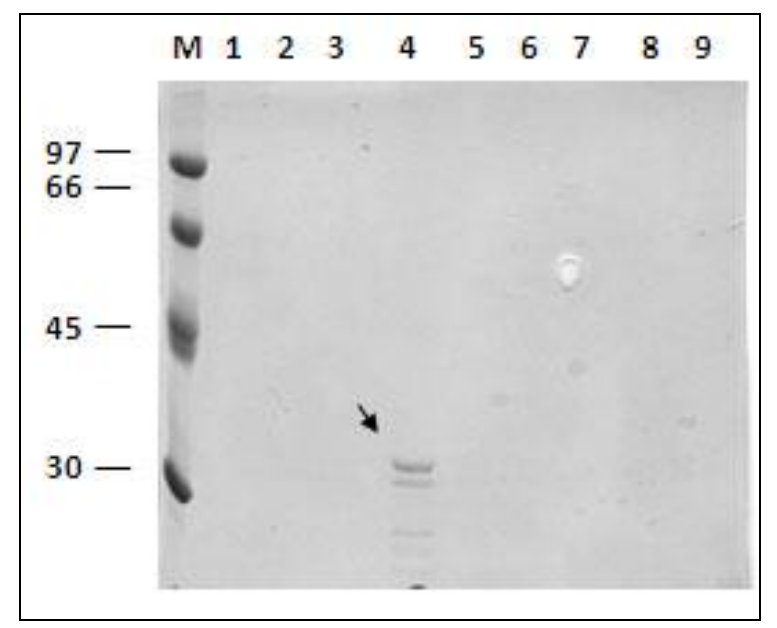

M, padrão de massa molecular (KDa); 1-9, frações. Seta indica a banda correspondente á proteína.

\subsection{Caracterização da resposta imunológica promovida pelas proteínas recombinantes em camundongos}

A produção de anticorpos e o desencadeamento de uma resposta celular são indicativos da ativação do sistema imune. O potencial imunogênico de rLIC11087, rLIC11228 e rLIC11084 foram avaliados com a imunização de camundongos. Os animais foram imunizados com uma dose e dois reforços como descrito anteriormente, e então sacrificados para a avaliação da resposta celular.

Todas as proteínas foram capazes de estimular a produção de anticorpos. O título de IgG total obtido para o grupo imunizado com rLIC11084 e rLIC11087 chegou a 1:400.000 na ultima imunização. A proteína rLIC11228 foi menos imunogênica quanto a produção de anticorpos, o título obtido chegou a 1:100.000 na última imunização (Figura 10). 
Figura 10- Produção de anticorpos por camundongos imunizados após segundo reforço

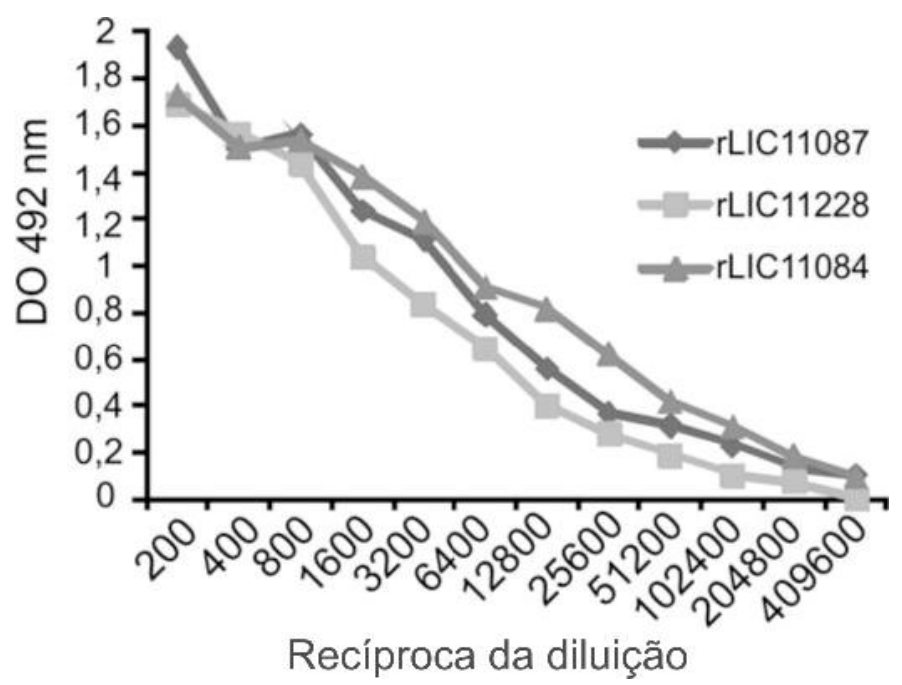

(A) Detecção de anticopos nos soros de camundongos imunizados com rLIC11087; rLIC11228 e rLIC11084. Os animais foram imunizados subcutaneamente com três doses contendo $10 \mathrm{~g}$ de proteína recombinante em Alhydrogel (Brenntag). O título dos soros obtidos foi determinado a diluição com densidade ótica 0,1 .

A proliferação de esplenócitos foi avaliada e expressa na forma de índice de estimulação, isto é razão entre a absorbância de células do grupo imunizado e reestimulada in vitro (incorporação de BrdU) com a absorbância células do grupo apenas imunizado (não reestimulada). Os dados são considerados significativos caso esta razão seja superior a 1 (FAISAL et al., 2008).

A proteína rLIC11084 foi capaz de estimular a proliferação de esplenócitos em dois experimentos independentes. $\mathrm{O}$ índice de estimulação foi respectivamente de 1,6 e 6 para o primeiro e segundo experimento (Figura 12).

As proteínas rLIC11087 e rLIC11228 estimularam a proliferação de esplenócitos em apenas um experimento. O índice de estimulação no segundo experimento foi 9 para rLIC11087, e 3 para rLIC11228 (Figura 11).

A viabilidade das células empregadas nestes experimentos foi evidenciada com o estímulo de linfoproliferação em resposta a concanavalina A. $\quad \mathrm{O}$ segundo experimento não produziu os resultados esperados. $\mathrm{O}$ valor do indice de estimulação obtido com células estimuladas com ConA foi inferior ao índice de estimulação obtido com células estimuladas com as proteínas teste. Assim outros experimentos, assim como a padronização da metodologia são necessários para investigar a geração de células de memória após a imunização com estes antígenos. 
Figura 11- Proliferação de esplenócitos de animais imunizados in vitro.

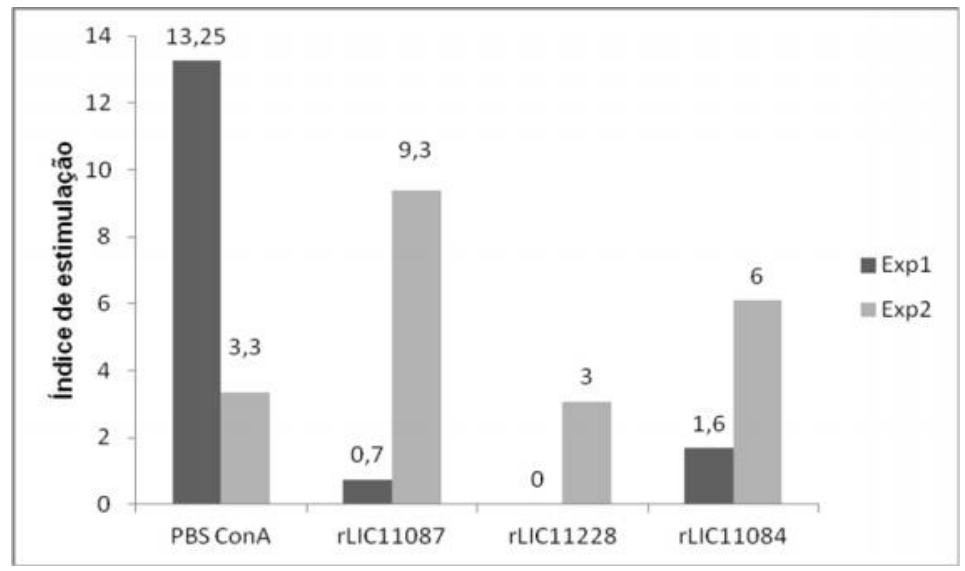

Índice de estimulação foi representado com a razão entre densidade ótica obtida pela incorporação de BrdU por células estimuladas com a densidade ótica obtida pela incorporação de BrdU por células não estimuladas. Dados de dois experimentos independentes.

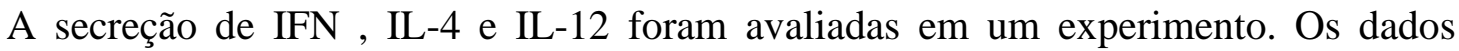

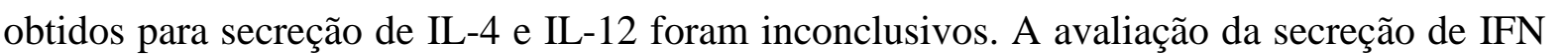

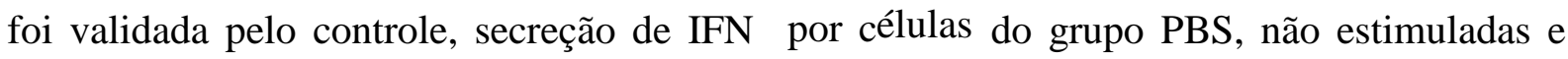
estimuladas com concanavalina A.

A proteína rLIC11084 foi capaz de estimular a secreção de IFNץ por células de animais imunizados em dois experimentos independentes (Figura 12). Contudo outros experimentos são necessários para confirmar a indução da secreção de IFNץ por células de animais imunizados com rLIC11084, assim como a importância deste achado no desencadeamento de uma resposta protetiva.

As proteínas rLIC11087 e rLIC11228 não estimularam de maneira estatisticamente significante a secreção de IFN $\gamma$ (figura 12). 
Figura 12- Secreção de IFN $\gamma$ por esplenócitos de animais imunizados.

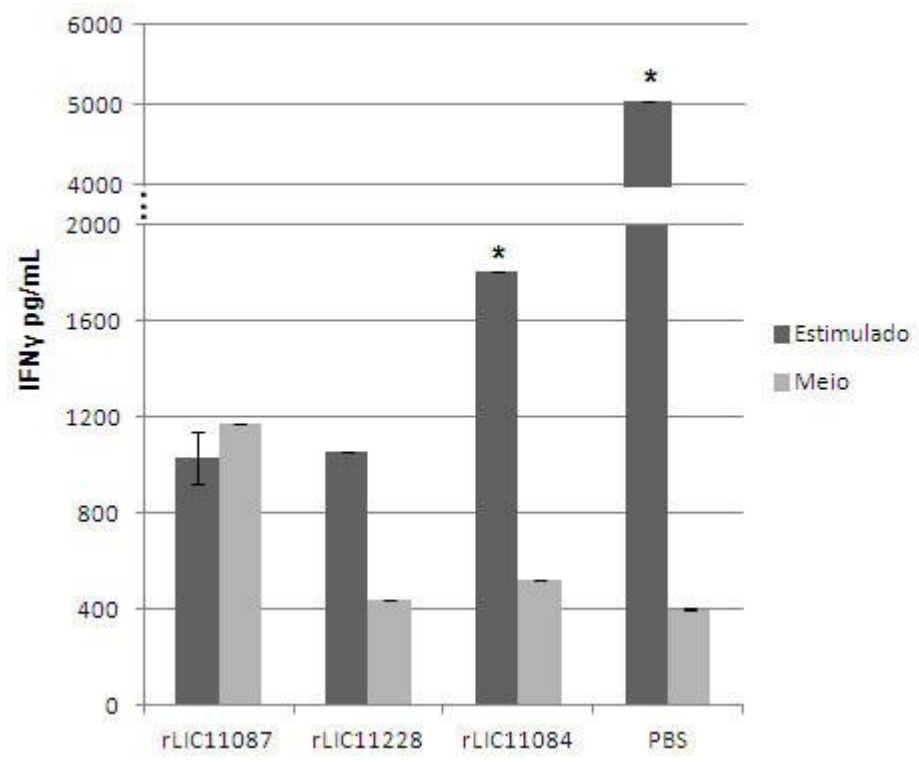

Grupos de animais ( $\mathrm{n}=5)$ foram imunizados com $10 \mathrm{~g}$ da proteína teste ou PBS. As células $\left(10^{8}\right)$ foram reestimuladas com $1 \mathrm{~g}$ de cada antígeno. Grupo PBS foi estimulado ou não com concanavalina $\mathrm{A}$ (controle positivo e negativo). Asteriscos demonstram significância estatística em relação aos controles, células não reestimuladas (meio). Teste T: $(*) \mathrm{P}<0,05$.

IFN $\gamma$ pode desencadear diferentes mecanismos efetores no sistema imune adaptativo.

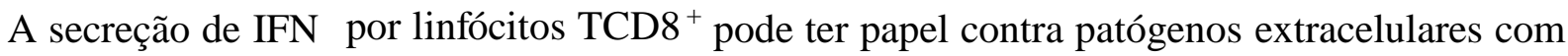
a ativação de macrófagos e promoção indireta da secreção de IgG2 (GUO et al., 2010). Além disso, a secreção de IFN $\gamma$ por linfócitos T auxiliares pode promover a diferenciação de células B e linfócitos TCD8 ${ }^{+}$em efetores imunologicamente ativos (GATTONI et al., 2006).

$\mathrm{O}$ aumento na secreção de IFN $\gamma$ por hamsters infectados com L. interrogans sv.Icterohaemorragiae foi descrito (VERNEL-PAULLAC; GOARANT, 2010). No entanto o envolvimento desta citocina na resistência a doença não foi evidenciado inoculando bactérias virulentas em camundongos Knockout C57BL/6 IFN-KO, deficientes na produção de IFN (ATHANAZIO et al., 2008).

A secreção de IFN $\gamma$ por linfócitos $\mathrm{TCD}^{+}$e linfócitos $\mathrm{T} \gamma \delta$ foi relacionada á proteção após a administração de vacinas composta por células inativadas da espécie $L$. borgpetersenii (NAIMAN et al., 2001). A proteção parcial de hamsters foi atribuída a um efeito sinergistico na coadministração das proteínas de superfície OmpL1 e Lip41 (HAAKE et al., 1999). A imunização de epítopos destes imunógenos culminou com uma resposta Th1, atribuído á

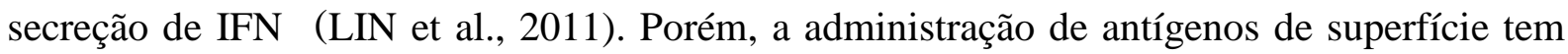
culminado tanto com a secreção de IFN $\gamma$ como com a secreção de citocinas relacionadas com 
resposta Th2 (FAISAL et al., 2009b, c; YAN et al., 2009). A análise do perfil protetor de rLIC11084 bem com a caracterização da resposta imune desencadeada por este imunógeno pode auxiliar no desenvolvimento de uma estratégia vacinal contra leptospirose.

\subsection{Avaliação do perfil protetor de hamsters imunizados com rLIC11084 frente desafio letal}

Proteínas de membrana externa são os principais alvos para o desenvolvimento de uma vacina eficaz contra leptospirose. Diferentes proteínas de membrana externa tem estimulado imunidade protetora, no entanto não foi descoberto nenhum candidato em potencial para o desenvolvimento de uma vacina.

A proteção conferida pela proteína codificada pelo gene LIC11087 foi avaliada e não resultou na proteção de animais desafiados (FÉLIX et al., 2011). O rendimento da proteína rLIC11228 impossibilitou a realização de experimentos de imunoproteção. Assim o perfil protetor do antígeno rLIC11084 foi avaliado com desafio letal de hamsters.

Os animais foram imunizados como descrito anteriormente descrito e então foram desafiados com 1X a DL50 de L. interrogans sv. Kennewicki linhagem Pomona Fromm. Foram realizados dois experimentos e a secreção de anticorpos foi avaliada com sangria via plexo retro orbital em seis animais imunizados.

A imunização dos animais induziu produção de anticorpos nos dois experimentos. No primeiro experimento o título dos animais imunizados foi de 12.800 na primeira sangria e na segunda. Esse título se manteve em um dos animais sobreviventes. No segundo experimento a maioria dos animais apresentaram título de 400 na primeira sangria e 6:400 na segunda sangria. No animal sobrevivente o título foi de 1:200.

No primeiro experimento a sobrevida de animais imunizados foi maior que a sobrevida dos animais do grupo controle. Porém este resultado não foi estatisticamente significante quando avaliado pelo método de Kaplan-Meier (Figura 13A). Em todos os animais sobreviventes deste experimento foi possível isolar leptospiras dos rins.

No segundo experimento apenas um animal imunizado com rLIC11084 sobreviveu, não foi constatado colonização renal nele (Figura 13B).

O grupo imunizado com bacterina teve $100 \%$ de sobrevida nos dois experimentos, e nos animais não imunizados, grupo PBS, a taxa de sobrevivência variou entre $8,3 \%$ e $25 \%$ (Figura 13A e B). 
Figura 13- Curva de sobrevivência de animais imunizados com rLIC11084
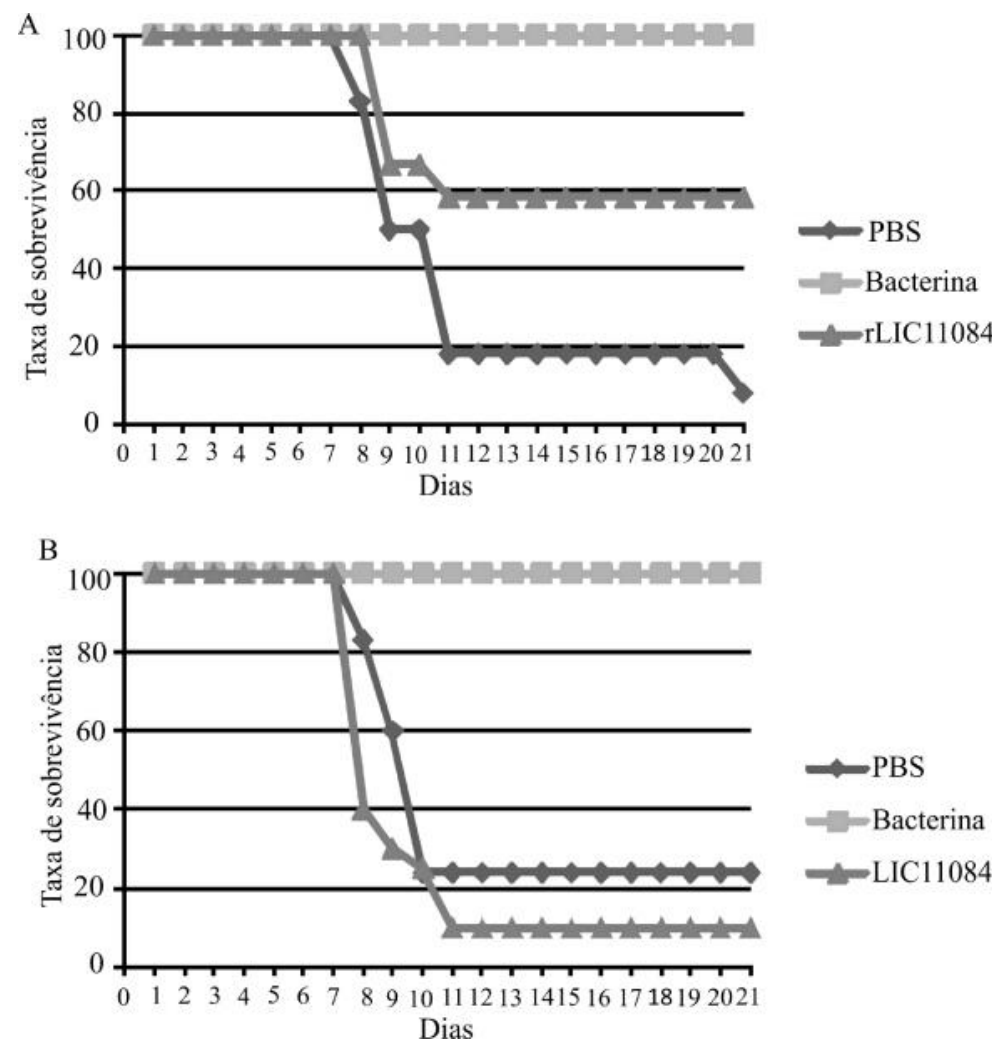

Os animais foram imunizados como descrito em materiais e métodos e desafiados com L. interrogans sv. Kennewicki linhagem Pomona Fromm. A) Curva de sobrevivência do primeiro experimento; B) Curva de sobrevivência do segundo experimento. A análise estatística pelo método Kaplan-Meier resultou no $p$ value 0.0491 para o primeiro experimento e $p$ value 0.1934 para o segundo experimento (KAPLAN; MEIER, 1958).

A falta de reprodutibilidade de resultados de imunoproteção é relatada com frequência em experimentos que avaliam a imunoproteção de hamsters (ATZINGEN et al., 2012, 2010; BRANGER et al., 2001; YAN et al., 2010). Além disso, taxa de sobrevivência nos animais do grupo controle tornou insignificante o resultado de sobrevivência no primeiro experimento, problema já descrito em outros trabalhos (ATZINGEN et al., 2010, 2012; BRANGER et al., 2001).

\subsection{Reatividade das proteínas recombiantes com soro de hamsters infectados e de pacientes diagnosticados com leptospirose}

Algumas proteínas têm sido reconhecidas no soro de animais e pacientes infectados. Estes resultados podem ser um indicativo da expressão destas proteínas durante a infecção e 
indicar o potencial das mesmas no desenvolvimento de métodos diagnósticos (DOMINGOS et al., 2012; FERNANDES et al., 2012; MENDES et al., 2011; NEVES et al., 2007; OLIVEIRA et al., 2008; OLIVEIRA et al., 2011; PINNE et al., 2010; PRETRE et al., 2013; VIEIRA et al., 2010a). Testes sorológicos baseados na identificação de anticorpos contra proteínas recombinantes podem conferir alta sensibilidade e especificidade devido á alta concentração de antígenos, a ausência de motivos não específicos e conservação entre diferentes espécies patogênicas do gênero Leptospira. (TOYOKAWA; OHNISHI; KOIZUMI, 2011).

Assim foi investigado a presença de anticorpos IgG específicos a rLIC11087, rLIC11228 e rLIC11084 no soro de hamsters infectados e de pacientes com leptospirose. Foram empregadas amostras MAT+ de soro de hamsters experimentalmente infectados. A presença de anticorpos específicos a proteína rLIC11087 foi analisada em 42 amostras e foi identificado 19 respondedores (45,2\%) (Figura 14A). Este pode ser um indicativo de que esta proteína é expressa durante a infecção.

A presença de anticorpos específicos as proteínas rLIC11228 e rLIC11084 foi analisada em 32 amostras. As análises resultaram na identificação de 1 respondedor $(3,1 \%)$ para estas proteínas (Figura 14 B e C).

Para o calculo do cutoff, a reatividade da proteína rLIC11087 foi analisada em 8 amostras de soro de animais não infectados e a reatividade das proteínas rLIC11228 e rLIC11084 foi analisada em 12 amostras de soro de animais não infectados. 
Figura 14- Reconhecimento das proteínas recombinantes por anticorpos presentes no soro de hamsters infectados.
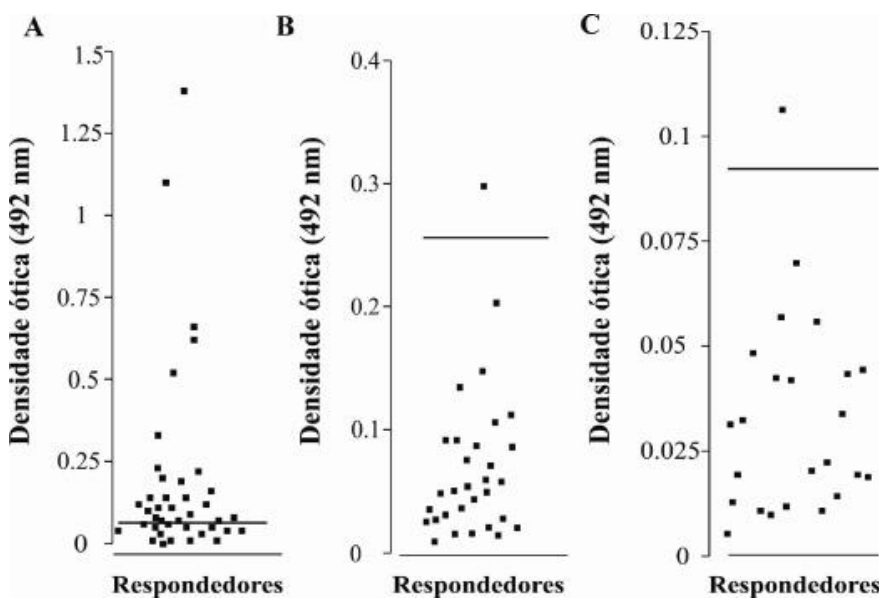

(A) Lsa30, (B) rLIC11228 e (C) rLIC11084. Barras indicam cutoff. Os valores de cutoff para Lsa30, rLIC11228 e rLIC11084 são respectivamente 0,$09 ; 0,25$ e 0,09 .

A presença de anticorpos específicos á proteína rLIC11087 foi analisada em 33 amostras de soro MAT- e 43 amostras de soro MAT+. Foi constatado 7 (21\%) e 13 (30\%) respondedores nos soros MAT- e MAT+, respectivamente (Figura 15A e B).

A detecção da proteína rLIC11228 por anticorpos específicos foi avaliada em 25 amostras de soros pareados (MAT- e MAT+). Foi constatado 7 (28\%) e 16 (64\%) respondedores nos soros das fases MAT- e MAT+, respectivamente (Figura 15C e D).

A presença de anticorpos contra a proteína rLIC11084 foi analisada em 34 amostras de soros MAT- e 44 amostras de soro MAT+. Foram identificados $8(23,5 \%)$ e $21(47 \%)$ respondedores nos soros das fases MAT- e MAT+, respectivamente (Figura 15 E e F).

Amostras de soros normais obtidos comercialmente foram analisadas em quadruplicata. Foram avaliados apenas os soros pareados das amostras MAT-, isto é soros de um mesmo paciente na fase inicial e convalescente da doença. 
Figura 15- Reconhecimento das proteínas recombinantes por anticorpos presentes no soro de paciente diagnosticados com leptospirose
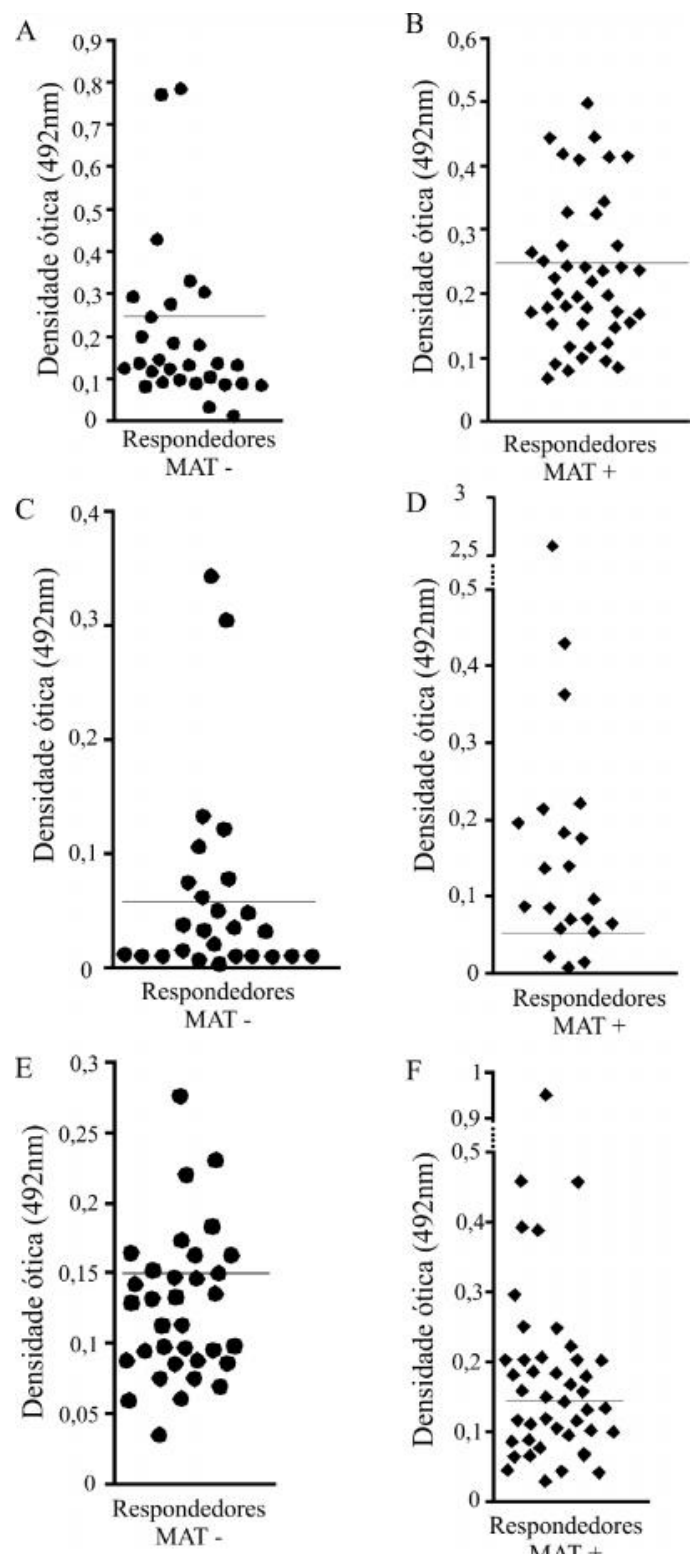

(A e B) rLIC11087, (C e D) rLIC11228 e (E e F) rLIC11084. Barras indicam cutoff. Os valores de cutoff para rLIC11087, rLIC11228 e rLIC11084 são respectivamente 0,25; 0,06 e 0,15 .

\subsection{Interação das proteínas recombinantes com componentes de matriz extracelular}

A invasividade de leptospiras está atribuída a sua habilidade de disseminar pelos tecidos do hospedeiro nas fases iniciais da infecção, porém os mecanismos associados a esta invasividade não foram esclarecidos até o presente momento (FAINE et al., 1999). Um estudo pré genômico culminou com a identificação de uma proteína ligante á fibronectina (MERIEN et al., 2000). O sequenciamento genomico possibilitou identificação de adesinas afimbriais 
(NASCIMENTO et al., 2004a). Desde então muitas proteínas de superfície com capacidade de ligação á componentes de matriz vem sendo identificadas (ATZINGEN et al., 2008, 2010; BARBOSA et al., 2006; CARVALHO et al., 2009; CHOY et al., 2007; DOMINGOS et al., 2012; FERNANDES et al., 2012; HAUK et al., 2009; HOKE et al., 2008; MENDES et al., 2011; OLIVEIRA et al., 2011; STEVENSON et al., 2007). Além disso, algumas proteínas de leptospira provocam o aumento da expressão dos receptores de células eucarióticas ICAM-1 e E-selectina em células endoteliais (ATZINGEN et al., 2009; GOMEZ et al., 2008; VIEIRA et al., 2007).

As proteínas rLIC11087 e rLIC11228, semelhante á outras proteínas descritas pelo nosso grupo, podem auxiliar na adesão da bactéria as células do hospedeiro pela interação com ECM. Semelhante a Lsa66 e Lsa20 (MENDES et al., 2011; OLIVEIRA et al., 2011), as proteínas rLIC11087 e rLIC11228 interagem com laminina e fibronectina plasmática (Figura 16). Essas interações foram analisadas por ELISA com a detecção das proteínas recombinantes por anticorpos policlonais homólogos e anticorpos monoclonais contra resíduos de histidina (Figura 16A e B).

Devido a interação da proteína rLIC11087 com estes componentes ela foi nomeada Lsa30, “Leptospiral surface adhesin of $30 \mathrm{KDa”} \mathrm{(SOUZA} \mathrm{et} \mathrm{al.,} \mathrm{2012).}$

Figura 16- Adesão das proteínas recombinantes á componentes de matriz extracelular
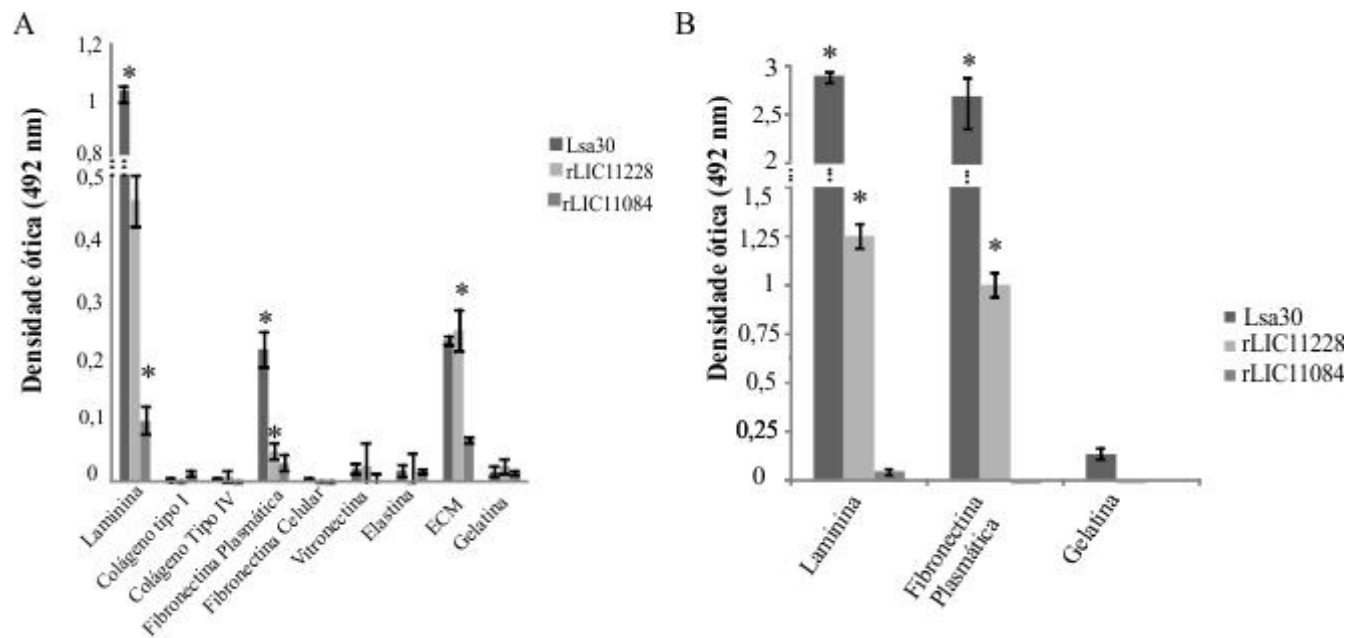

1 g de cada componente foi imobilizado na placa e a interação com $1 \mathrm{~g}$ de cada proteína foi avaliada por ELISA. (A) Detecção das proteínas por anticorpos homólogos policlonais (B) confirmação da interação das proteínas recombinantes aos seus ligantes por anticorpos monoclonais contra resíduos de histidina. Asteriscos demonstram significância estatística em relação ao controle gelatina. Teste $\mathrm{T}:(*) \mathrm{P}<0,05$.

As interações de Lsa30 foram dose dependente, a saturação da reação foi alcançado na concentração de 1,5 M para interação com laminina e fibronectina plasmática. A constante 
de dissociação calculada foi de $292 \pm 24 \mathrm{nM}$ para interação com laminina e $157 \pm 35 \mathrm{nM}$ para interação com fibronectina plasmática (Figura 17A).

A proteína rLIC11228 também demonstrou interação com laminina e fibronectina plasmática. Estas ligações foram dose dependente e a saturação foi alcançada na concentração de $250 \mathrm{nM}$ para laminina e $500 \mathrm{nM}$ fibronectina plasmática. A constante de dissociação foi de 36,4 \pm 6 M para interação com laminina e 3,8 $\pm 0,43$ M para interação com fibronectina plasmática (Figura 17B).

A interação entre a proteína rLIC11084 e laminina, visualizada na Figura 13, não foi dose resposta e então pode ser considerada inespecífica (Figura 17C). 
Figura 17- Curva dose-resposta para análise da ligação das proteínas recombinantes aos seus respectivos ligantes.
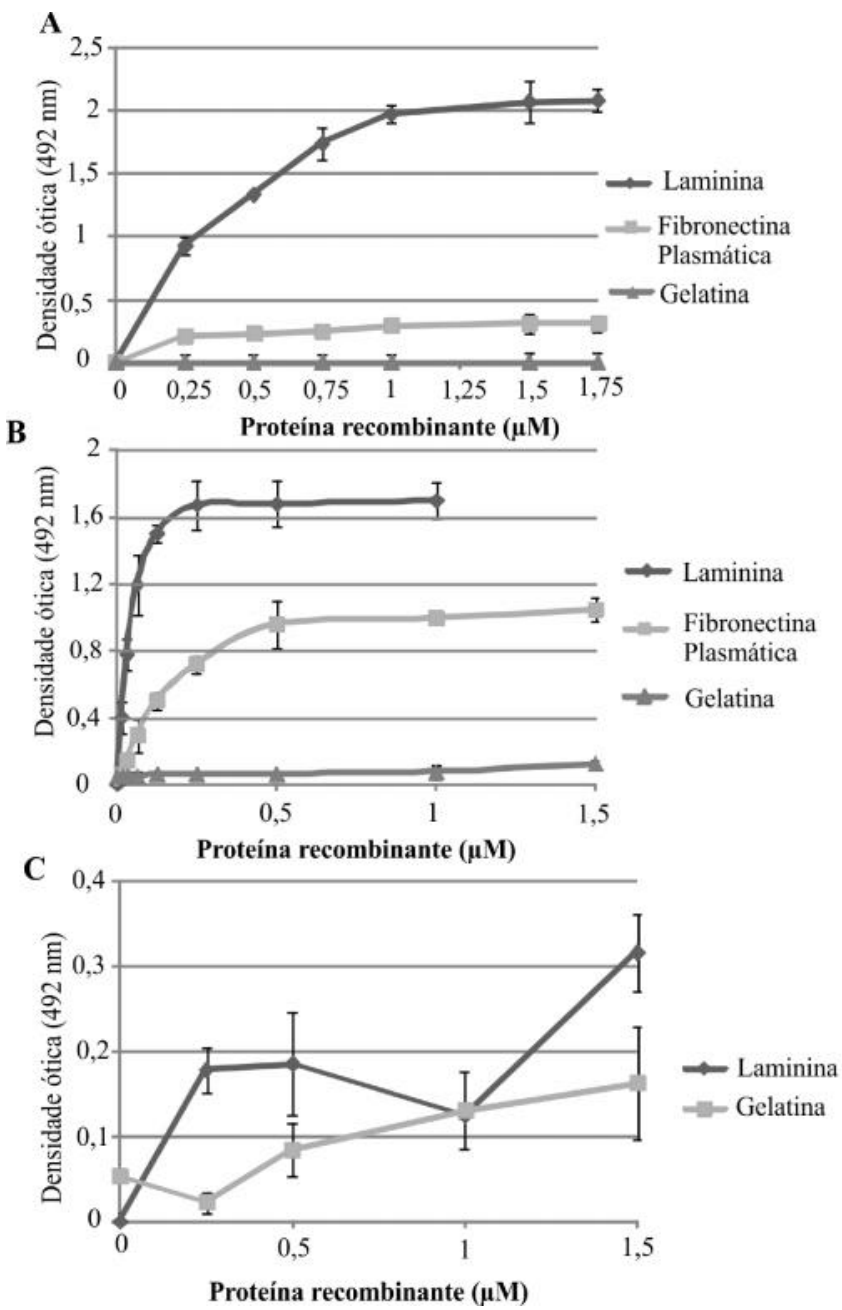

$1 \mathrm{~g}$ de cada componente ligante foi imobilizado na placa e concentrações crescentes da proteína foi adicionado para análise da interação. As proteínas foram detectadas com anticorpos homólogos. Gelatina foi empregado como controle negativo dos experimentos. (A) Interação de Lsa30 com laminina e fibronectina plasmática (01,75 M). (B) Interação de rLIC11228 com laminina e fibronectina plasmática $(0-1,5$ M). (C) Interação de rLIC11084 com laminina (0-1,5 $\mathrm{M})$. Dados representam a média e o desvio padrão de triplicatas. Constante de dissociação $\left(K_{D}\right)$ foi calculada apartir dos dados de ELISA.

A ligação de Lsa30 e rLIC11228 desnaturadas por fervura á laminina e a fibronectina plasmática foi avaliada. Os resultados mostram que a ligação destas proteínas á laminina não depende da estrutura, mas a interação das mesmas com fibronectina plasmática é depende da estrutura da proteína uma vez que a proteína submetida ao processo de fervura não interagiu com tal componente (Figura 18). 
Figura 18- Efeito da estrutura das proteínas recombinantes na adesão a componentes de matriz extracelular.

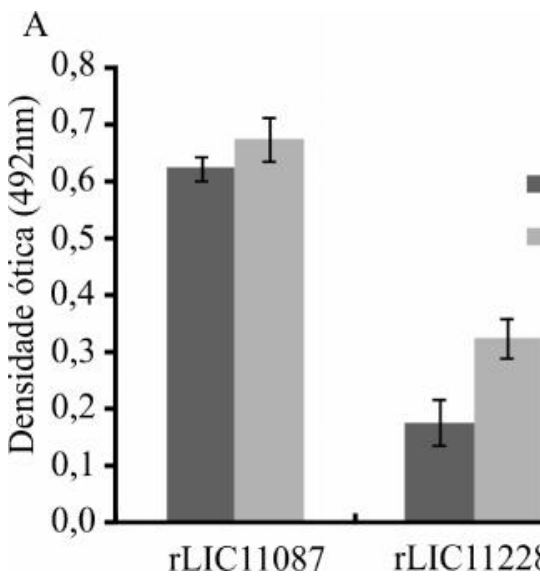

B

A) análise da adesão de Lsa30 e rLIC11228 á laminina. B) análise da adesão de Lsa30 e rLIC11228 á fibronectina plasmática, ${ }^{*} \mathrm{P}<0,05$.

\subsection{Interação das proteínas recombinantes com componentes do soro}

O processo de invasão de leptospiras não se limita a capacidade de adesão. Além de interagir com componentes de matriz extracelular leptospiras podem ter mecanismos de degradação da matriz extracelular e de evasão do sistema imune.

Proteínas de membrana externa podem desencadear estes mecanismos pela interação com proteínas séricas. Assim foi avaliado a interação de Lsa30, rLIC11228 e rLIC11084 com plasminogênio, fibrinogênio, componentes do sistema complemento bem como proteínas que atuam na sua regulação, como Fator $\mathrm{H}$ e C4bp.

As proteínas rLIC11228 e rLIC11084 interagiram apenas com o plasminogênio, já a proteína Lsa30, além de interagir com plasminogênio, foi capaz de interagir com o C4bp e fibrinogênio (Figura 19A).

A confirmação destas interações foi feita pela detecção das proteínas recombinantes com anticorpos monoclonais contra resíduos de histidina (Figura 19B). A interação entre a proteína rLIC11228 e fator $\mathrm{H}$ foi considerada inespecífica, mesmo que estatisticamente significante, devido a baixa intensidade da densidade ótica. 
Figura 19- Análise da interação das proteínas recombinantes com proteínas do soro humano.
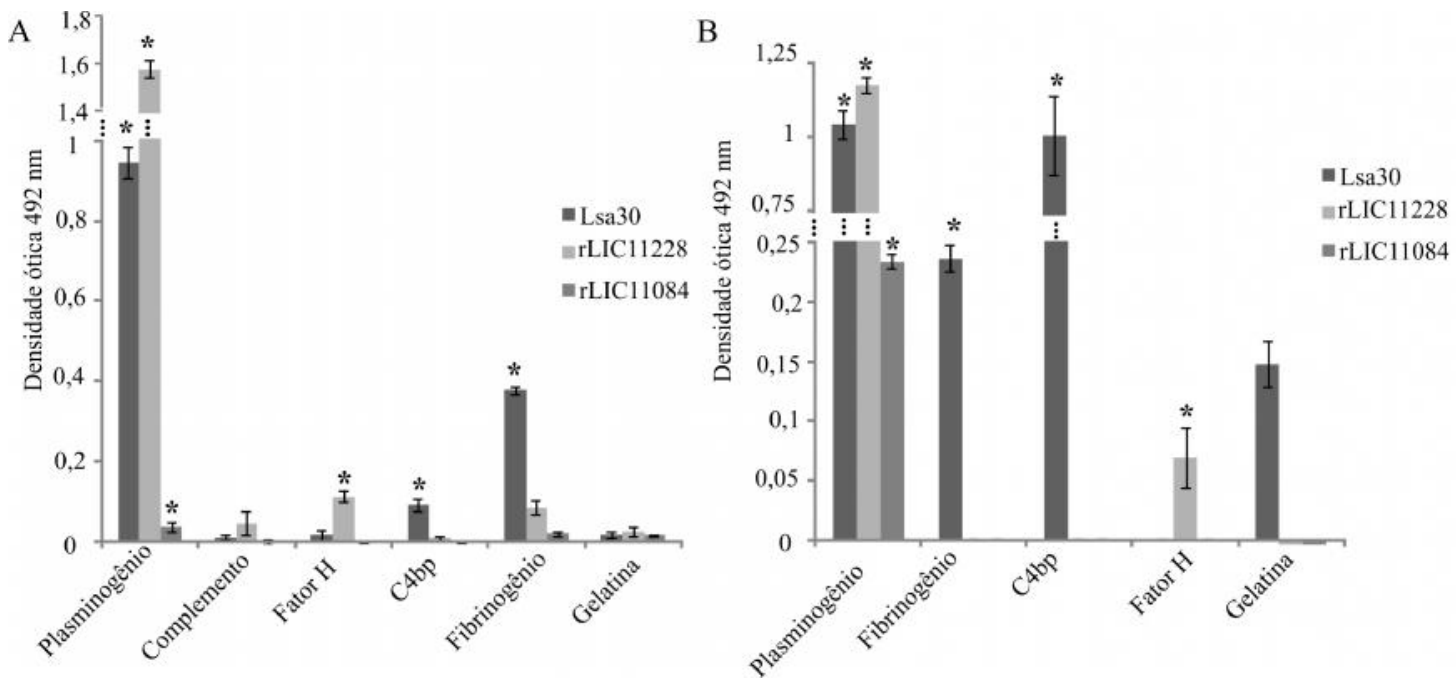

$1 \mathrm{~g}$ de cada componente foi imobilizado na placa e a interação com $1 \mathrm{~g}$ de cada proteína foi avaliada por ELISA. (A) Detecção das proteínas por anticorpos homólogos policlonais (B) confirmação da interação das proteínas recombinantes aos seus ligantes por anticorpos monoclonais contra resíduos de histidina. Asteriscos demonstram significância estatística em relação ao controle gelatina. Teste T: $(*) \mathrm{P}<0,05$.

A afinidade dessas proteínas aos seus ligantes também foi avaliada variando a concentração de proteína. Foi constatado que todas essas ligações são dose resposta, porém não foi possível atingir o nível de saturação da reação em Lsa30 e seus ligantes com as concentrações de proteína empregada (0 á 1,75 M).

A saturação da ligação de rLIC11084 ao plasminogênio foi atingida na concentração

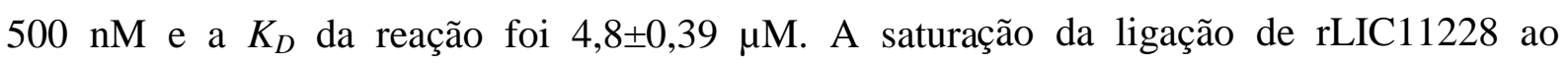
plasminogênio foi atingida na concentração de $125 \mathrm{nM}$ e a $K_{D}$ da reação foi $267,2 \pm 62,7$ M (Figura 20). 
Figura 20- Curvas dose resposta para análise da interação entre as proteínas recombinantes e componentes do soro

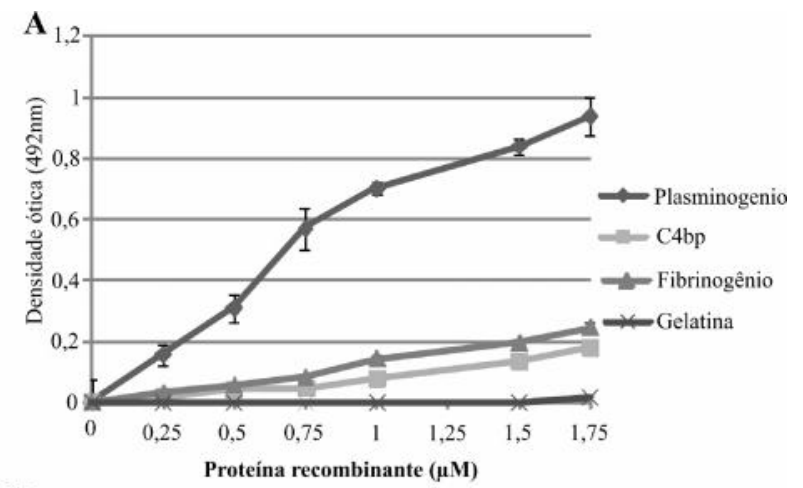

B
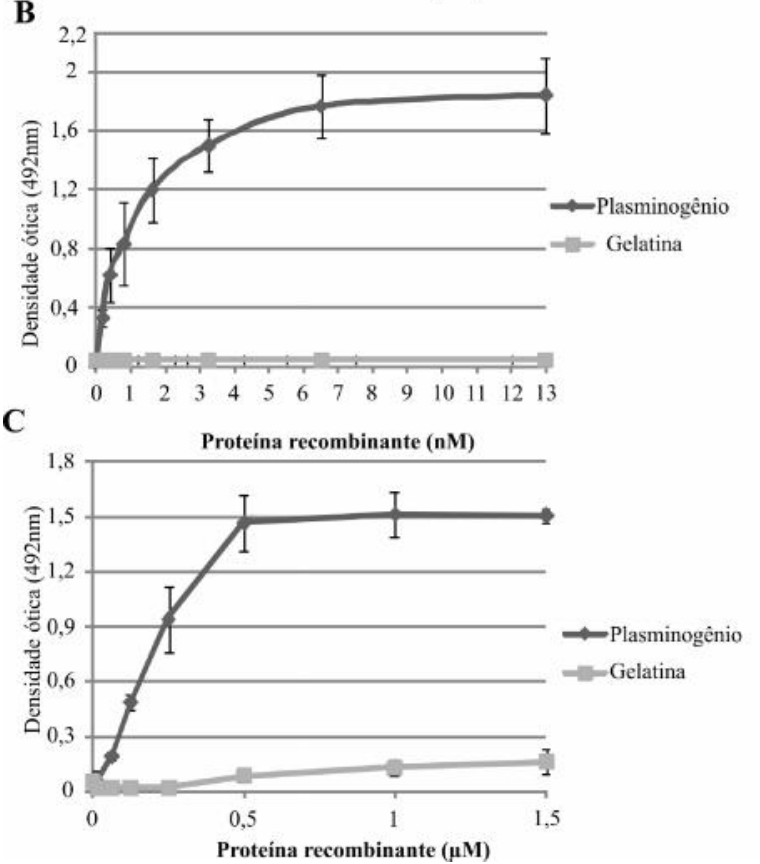

1 g de cada componente foi imobilizado na placa e concentrações crescentes da proteína foi adicionado para análise da interação. As proteínas foram detectadas com anticorpos homólogos. Gelatina foi empregado como controle negativo dos experimentos. (A) Interação de Lsa30 com Plasminogênio, C4bp e fibrinogênio (0-1,75

M). (B) Interação entre plasminogênio e rLIC11228 (1 á 13 nM). (C) Interação entre plasminogênio e rLIC11084 (0-1,5 M). Dados representam a média e o desvio padrão de triplicatas. Constante de dissociação $\left(K_{D}\right)$ foi calculada apartir dos dados de ELISA.

A interação de Lsa30, rLIC11228 e rLIC11084 com plasminogênio é dependente da estrutura das proteínas (Figura 21A). A estrutura de Lsa30 também é importante para sua com o C4pb, mas, pode não interferir na sua interação com o fibrinogênio. Apesar da redução na adesão da proteína desnaturada ao fibrinogênio não houve diferença estatística devido ao desvio padrão das amostras (Figura 21B e C). 
Figura 21- Análise da interação das proteínas desnaturadas ás proteínas do soro
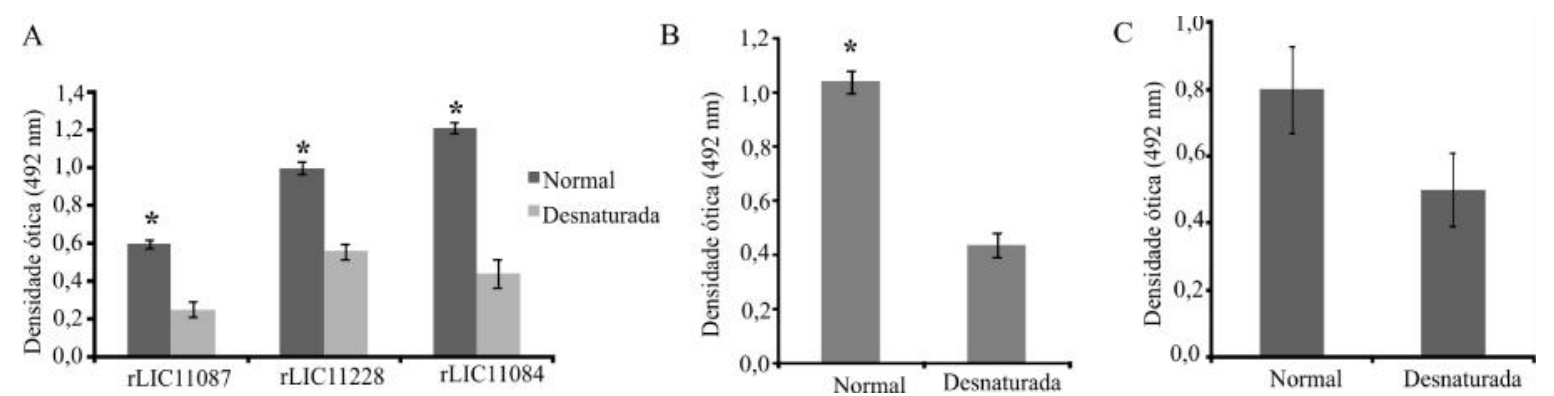

A) análise da adesão de Lsa30 , rLIC11228 e rLIC11084 ao plasminogênio. B) análise da adesão de Lsa30 ao C4bp . C) análise da adesão de Lsa30 ao fibrinogênio, ${ }^{*} \mathrm{P}<0,05$.

A degradação de componentes de matriz extracelular, C3b e IgG por leptospiras pela aquisição de plasminogênio e sua ativação em plasmina foi reportada. Este mecanismo pode estar envolvido na disseminação da bactéria e na evasão do sistema imune (VIEIRA et al., 2011, 2009). Lsa30, rLIC11228 e rLIC11084 podem ser receptores de plasminogênio assim como outras proteínas descritas (DOMINGOS et al., 2012; FERNANDES et al., 2012; MENDES et al., 2011; OLIVEIRA et al., 2011; VERMA et al., 2010b; VIEIRA et al., 2010b).

A interação entre proteínas e plasminogênio pode ocorrer entre os resíduos de lisina da proteína e domínios Kringle do plasminogênio. Para avaliarmos se os resíduos de lisina são importantes na interação entre as proteínas Lsa30, rLIC11228 e rLIC11084 e plasminogênio empregamos ácido aminocapróico. A adição deste análogo de lisina interferiu na interação das proteínas recombinantes com o plasminogênio, o que sugere que os resíduos de lisina delas são importantes na interação com o plasminogênio (Figura 22). 
Figura 22- Interferência de ácido aminocapróico na ligação das proteínas ao plasminogênio

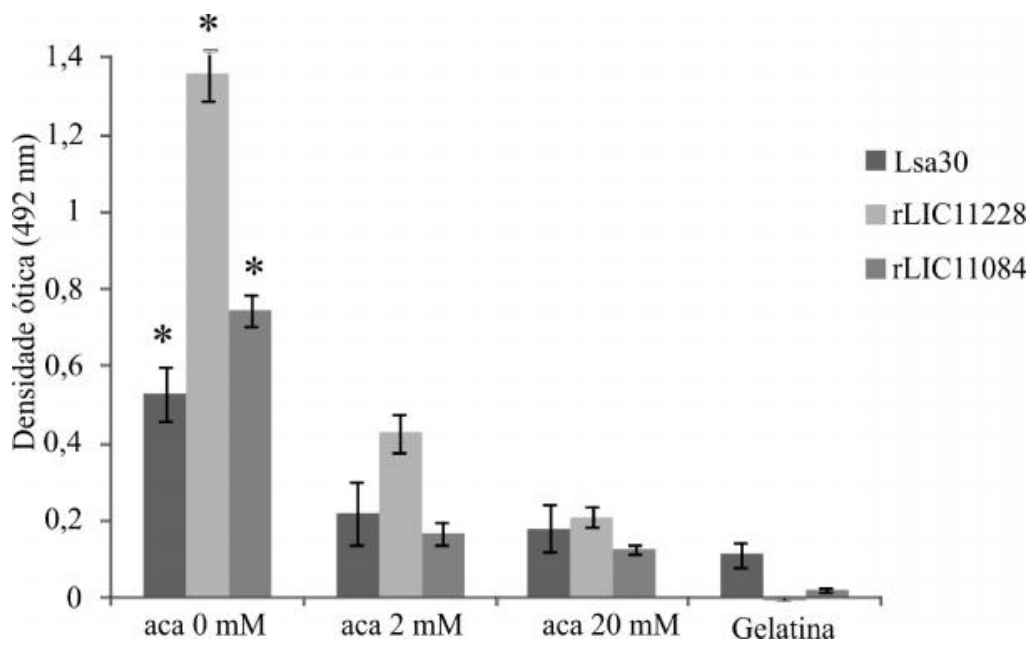

Plasminogênio foi imobilizado nas placas de ELISA. As proteínas recombinantes foram adicionadas em adição com o análogo de lisina ácido aminocapróico, que interferiu na interação das proteínas com plasminogênio. Análise estatistica foi realizada com os dados do controle gelatina e a concentração máxima do competidor. Houve diferença estatistica na interação de rLIC11228 e rLIC11084 com a adição de 2 mM de ácido aminocapróico. (*) $\mathrm{P}<0,05$.

Adicionalmente, o plasminogênio ligado á Lsa30, rLIC11228 e rLIC11084 pode ser convertido á plasmina pelo ativador uroquinase (SOUZA et al., 2012). O experimento foi validado uma vez que nas reações controle não foi observado a atividade enzimática de plasmina (Figura 23). A atividade enzimática da plasmina foi avaliada indiretamente pela detecção de substrato cromógeno. 
Figura 23- Detecção da atividade enzimática da plasmina a partir de plasminogênio ligado as proteínas recombinantes

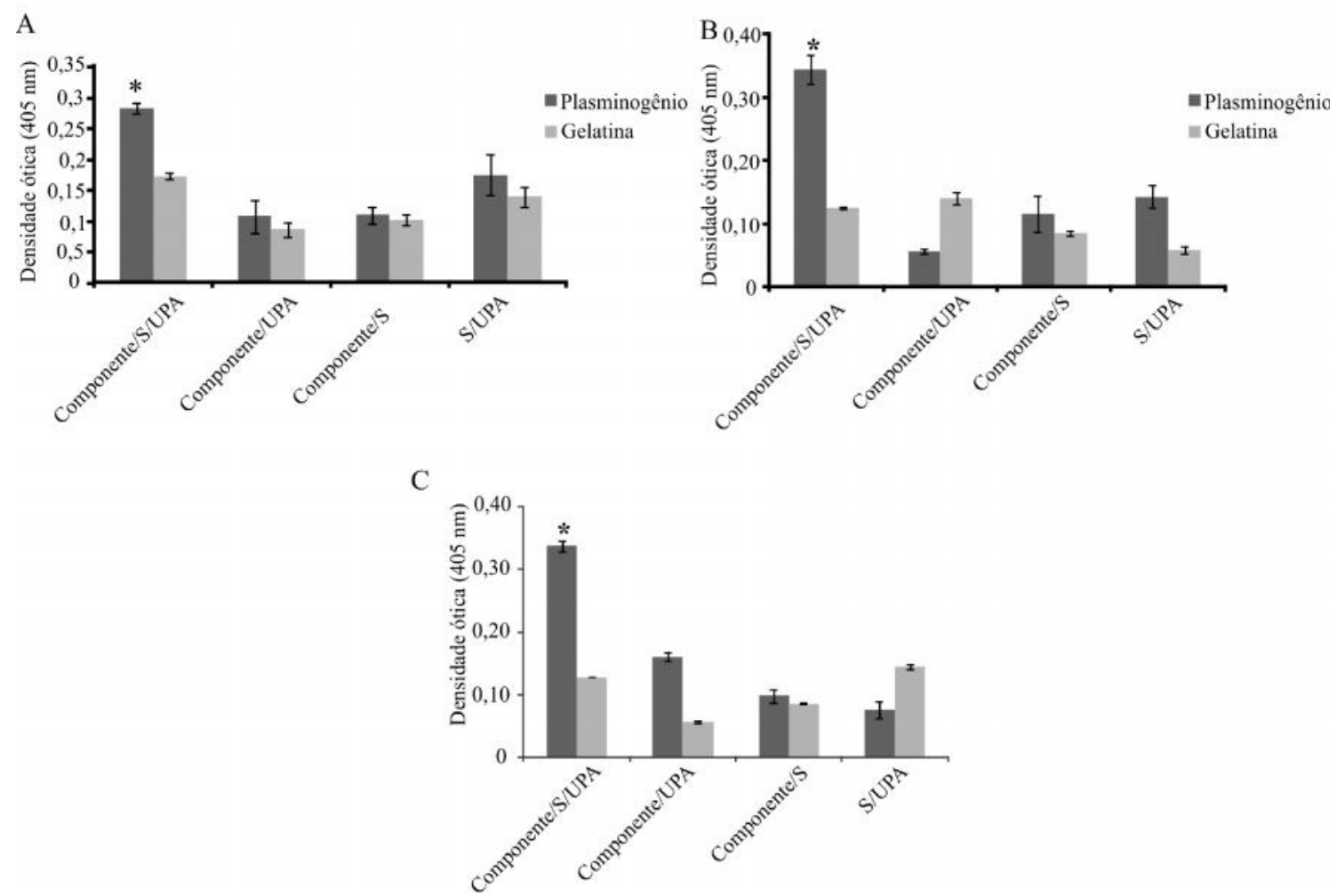

A proteína recombinante foi imobilizada na placa e os componentes para análise da atividade enzimática da plasmina foram adicionados. A) Imobilização de Lsa30. B) Imobilização de rLIC11228. C) Imobilização de rLIC11084. As análises estatísticas foram feitas com os dados obtidos com o controle negativo gelatina. (*) $\mathrm{P}<0,05$.

A interação de proteínas de patógenos com fibrinogênio pode interferir na cascata de coagulação e na adesão plaquetária (DAVIS et al., 2001; HAWIGER et al., 1982; LIN et al., 2011). Devido ao fato de Lsa30 ser mantida em pH12, condição que intefere na atividade enzimática da trombina, a interferencia dela na formação da rede de fibrina não pode ser avaliada.

\subsection{Detecção das proteínas nas leptospiras por imunofluorescencia}

As analises de bioinformática das CDS LIC11087 (Lsa30), LIC11228 e LIC11084 sugerem que estas proteínas estão presentes na membrana externa de L. interrogans. Para confirmação da localização celular destas proteínas nas leptospiras foi realizada a técnica de imunofluorescência. 
Neste experimento as células foram marcadas com iodeto de propídeo, molécula fluorescente que se intercala com o DNA, e com anticorpos conjugados com FITC, isto é em meio a detecção de proteínas na superfície. Para validação do experimento foi empregado os controles negativos PBS e células tratadas com anticorpos policlonais com DnaK, proteína citoplasmática. A detecção da proteína LipL32 foi empregada como controle positivo.

Foi observado co-marcação em verde e vermelho nas células tratadas com anticorpos contra as proteínas LipL32, Lsa30, rLIC11228 e rLIC11084. Isto pode ser um indicio da localização das mesmas na superfície de L. interrogans (Figura 24).

Figura 24- Identificação das proteínas nativas na membrana de $L$. interrogans $s v$. Copenhageni por imunofluorescência.

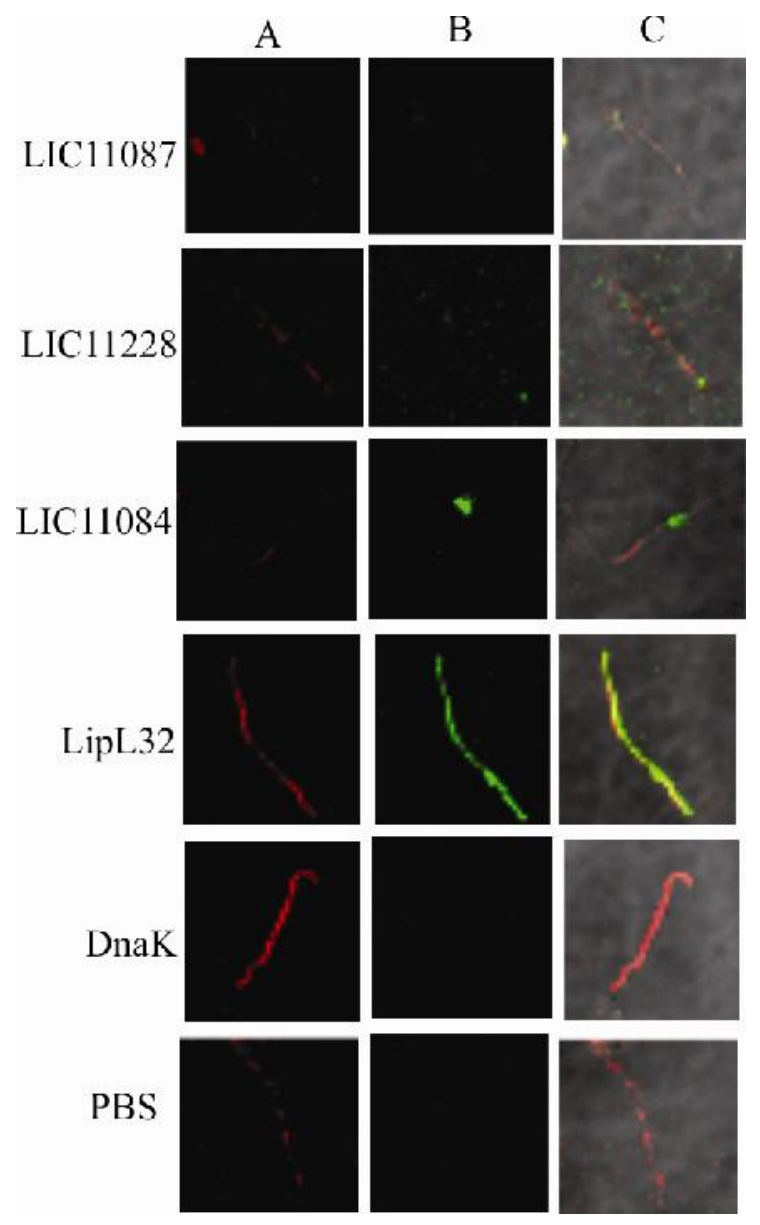

As células foram tratadas com anticorpos policlonais contra as rLI11087 (Lsa30), rLIC11228 e rLIC11084. Para controle do experimento as células foram tratadas com anticorpos policlonais contra LipL32, controle positivo, e DnaK, controle negativo, ou não foram tratadas. A) marcação das células com iodeto de propideo; B) marcação das células com FITC; C) comarcação das células. 
As células tratadas com anticorpos contra rLIC11087 (Lsa30), rLIC11228 e rLIC11084 foram fracamente marcadas. Isto pode ser atribuído ao baixo número de cópias destas proteínas por células (MALMSTROM et al., 2009). 


\section{CONCLUSÃO}

A análise das proteínas hipotéticas codificadas pelos genes LIC11121, LIC11087, LIC11228 e LIC11084 por bioinformática demonstrou que as proteínas codificadas por eles são antígenos em potencial devido sua possível localização na membrana externa de $L$. interrogan e a conservação dos mesmos em diferentes espécies de leptospiras. Assim estas proteínas foram escolhidas para serem caracterizadas.

Os genes foram amplificados e clonados no vetor de expressão pAE. A confirmação da clonagem foi realizada por sequenciamento dos plasmídeos recombinantes. As proteínas foram expressas em E. coli. A expressão das proteínas de interesse foi confirmada por immunoblotting com o emprego de anticorpos monoclonais contra resíduos de histidina.

As proteínas rLIC11087, rLIC11228 e rLIC11084 foram purificadas por cromatografia de afinidade ao metal em tampões com pH 12, condição na qual as proteínas foram mais estaveis. Não foi possível a purificação de rLIC11121 com os métodos de purificação empregados.

A proteína rLIC11084 foi purificada a partir da fração solúvel e apresentou rendimento próximo a $30 \mathrm{mg} / \mathrm{L}$ de cultura induzida. As proteínas rLIC11228 e rLIC11087 foram purificadas a partir da fração insolúvel e tiveram rendimento de aproximadamente $6 \mathrm{mg} / \mathrm{L}$ de cultura induzida e $4 \mathrm{mg} / \mathrm{L}$ de cultura induzida, respectivamente. Foi constatada por dicroísmo circular a presença de estrutura secundária nas proteínas rLIC11087 e rLIC11228 após o processo de purificação. A baixa elipcidade molar do espectro gerado com a análise da proteína rLIC11084 demonstra que o sinal captado pode ser ruído do tampão.

As proteínas recombinantes apresentaram imunogenicidade quando administradas em camundongos BALB/c. Todas foram capazes de estimular a produção de anticorpos. A proteína rLIC11084 foi capaz de estimular a proliferação de esplenócitos e a secreção de IFNץ. Adicionalmente esta proteína induziu proteção em $58 \%$ de hamsters imunizados, em um de dois experimentos independentes.

Outro indicio da imunogenicidade destas proteínas foi dado com a identificação de anticorpos reativos a elas no soro de pacientes infectados. Foram identificados respectivamente $30 \%, 64 \%$ e $47 \%$ de respondedores na fase convalescente para as proteínas rLIC11087, rLIC11228 e rLIC11084. Adicionalmente a proteína rLIC11087 também foi reconhecida por anticorpos presentes no soro de animais experimentalmente infectados (45\%). Estes resultados podem indicar ainda a expressão dessas proteínas durante a infecção. 
Essas proteínas podem estar envolvidas na patogênese de leptospira. As proteínas rLIC11087 (Lsa30) e rLIC11228 demonstraram interação com laminina e fibronectina plasmática.

As proteínas codificadas pelos genes LIC11087, LIC11228 e LIC11084 são ligantes de plasminogênio, adicionalmente o plasminogênio ligado a estas proteínas pode ser convertido a plasmina enzimaticamente ativa.

A proteína codificada pelo gene LIC11087 interagiu com C4bp, uma proteína reguladora do sistema complemento. Esta proteína também pode se ligar a fibrinogênio.

As interações entre as proteínas recombinantes deste trabalho com fibronectina plasmática, plasminogênio, C4bp dependem da estrutura das proteínas. A desnaturação das proteínas Lsa30 e rLIC11228 pode expor outros sítios dessas proteínas que interagem com laminina. Houv redução na ligação de Lsa30 ao fibrinogênio, porém este resultado não foi estatisticamente significante.

Estas proteínas foram identificadas na superficíe de L. interrogans por imunofluorescência, resultado que corrobora a predição realizada por bioinformática e mostra que estas proteínas são expressas pela bactéria.

Os dados obtidos neste trabalho sugerem que estas proteínas são imunogênicas, são expressas durante a infecção, podem estar envolvidas na patogenicidade de $L$. interrogans e estão localizadas na membrana externa da bactéria. 


\section{REFERÊNCIAS*}

ADLER, B.; DE LA PEÑA MOCTEZUMA, A. Leptospira and leptospirosis. Vet. Microbiol., v. 140, n. 3-4, p. 287-296, 2010.

AHMAD, S. N. et al. Laboratory diagnosis of leptospirosis. J. Postgrad. Med., v. 51, p. 195$200,2005$.

AHMED, A. et al. Development and validation of a real-time PCR for detection of pathogenic leptospira species in clinical materials. PLoS One, v. 4, p. e7093, 2009.

ALT, D. P.; ZUERNER, R. L.; BOLIN, C. A. Evaluation of antibiotics for treatment of cattle infected with Leptospira borgpetersenii serovar hardjo. J. Am. Vet. Med. Assoc., v. 219, n. 5, p. 636-639, 2001.

ALTSCHUL, S. F. et al. Gapped BLAST and PSI-BLAST: a new generation of protein database search programs. Nucleic. Acids. Res., v. 25, p. 3389-3402, 1997.

ALTSCHUL, S. F. et al. Basic local alignment search tool. J. Mol. Biol., v. 215, p. 403-410, 1990.

ATHANAZIO, D. A. et al. Experimental infection in tumor necrosis factor alpha, interferon gamma and interleukin 4 deficient mice by pathogenic Leptospira interrogans. Acta Trop., v. 105, p. 95-98, 2008.

ATZINGEN, M. V. et al. Evaluation of immunoprotective activity of six leptospiral proteins in the hamster model of leptospirosis. Open Microbiol. J., v. 6, p. 79-87, 2012.

ATZINGEN, M. V. et al. Characterization of leptospiral proteins that afford partial protection in hamsters against lethal challenge with Leptospira interrogans. J. Med. Microbiol., v. 59, p. 1005-1015, 2010.

ATZINGEN, M. V. et al. Lp95, a novel leptospiral protein that binds extracellular matrix components and activates e-selectin on endothelial cells. J. Infect., v. 59, p. 264-276, 2009.

ATZINGEN, M. V. et al. Lsa21, a novel leptospiral protein binding adhesive matrix molecules and present during human infection. BMC Microbiol., v. 8, 2008. doi: 10.1186/1471-2180-8-70.

BARBOSA, A. S. et al. Functional characterization of LcpA, a surface-exposed protein of Leptospira spp. that binds the human complement regulator C4BP. Infect. Immun., v. 78, p. 3207-3216, 2010.

BARBOSA, A. S. et al. A newly identified leptospiral adhesin mediates attachment to laminin. Infect. Immun., v. 74, p. 6356-6364, 2006.

\footnotetext{
* De acordo com: ASSOCIAÇÂO BRASILEIRA DE NORMAS TÉCNICAS. NBR 6023: informação e documentação: referências: elaboração. Rio de Janeiro, 2002.
} 
BAROCCHI, M. A. et al. Rapid translocation of polarized MDCK cell monolayers by Leptospira interrogans, an invasive but nonintracellular pathogen. Infect. Immun., v. 70, p. 6926-6932, 2002.

BHANDARI, P.; GOWRISHANKAR, J. An Escherichia coli host linhagem useful for efficient over production of cloned gene products with $\mathrm{NaCl}$ as the inducer. J. Bacteriol., v. 179, p. 4403-4406, 1997.

BHARTI, A. R. et al. Leptospirosis: a zoonotic disease of global importance. Lancet Infect. Dis., v. 3, n. 12, p. 757-771, 2003.

BLACKSELL, S. D. et al. Limited diagnostic capacities of two commercial assays for the detection of Leptospira immunoglobulin M antibodies in Laos. Clin. Vaccine Immunol., v. 13, p.1166-1169, 2006.

BRANGER, C. et al. Protection against Leptospira interrogans sensu lato challenge by DNA immunization with the gene encoding hemolysin-associated protein 1. Infect. Immun., v. 73, p. 4062-4069, 2005.

BRANGER, C. et al. Identification of the hemolysis-associated protein 1 as a cross-protective immunogen of Leptospira interrogans by adenovirus-mediated vaccination. Infect. Immun., v. 69, p. 6831-6838, 2001.

BRASIL. Ministério da Saúde. GVE - Guia de Vigilância Epidemiológica. 2005. Publicações Técnica e Científicas - Secretaria de Vigilância em Saúde/ Ministério da Saúde Disponível em: <http:// www.saude.gov.br/bvs>. Acesso em: 27 abr. 2010.

BRASIL. Ministério da Saúde. Leptospirose, dados epidemiológicos das unidades federadas: $1997-2012.2012 .2$ Disponível em: <http://portal.saude.gov.br/portal/arquivos/pdf/tab_casos_conf_ser_hist_1997_2012.pdf〉.

Acesso em: 7 fev. 2013

BREINER, D. D. et al. Leptospira interrogans binds to human cell surface receptors including proteoglycans. Infect. Immun., v. 77, p. 5528-5536, 2009.

BRENNER, D. J. et al. Further determination of DNA relatedness between serogroups and serovars in the family Leptospiraceae with a proposal for Leptospira alexanderi sp. nov. and four new Leptospira genomospecies. Int. J. Syst. Bacteriol., v. 49, n. 2, p. 839-858, 1999.

BROWN, P. D. et al. Evaluation of the polymerase chain reaction for early diagnosis of leptospirosis. J. Med. Microbiol., v. 43, p. 110-114, 1995.

BULACH, D. M. et al. Genome reduction in Leptospira borgpetersenii reflects limited transmission potential. Proc. Natl. Acad. Sci. U. S. A., v. 103, p. 14560-1465, 2006.

$\mathrm{CAO}$, Y. et al. Evaluation of novel fusion proteins derived from extracellular matrix binding domains of LigB as vaccine candidates against leptospirosis in a hamster model. Vaccine, v. 29, p. 7379-7386, 2011. 
$\mathrm{CAO}, \mathrm{X}$. J. et al. High-coverage proteome analysis reveals the first insight of protein modification systems in the pathogenic spirochete Leptospira interrogans. Cell. Res., v. 20, p. 197-210, 2010.

CARVALHO, E. et al. Leptospiral TlyC is an extracellular matrix-binding protein and does not present hemolysin activity. FEBS Lett., v. 583, p. 1381-1385, 2009.

CASTIBLANCO-VALENCIA, M. M. et al. Leptospiral immunoglobulin-like proteins interact with human complement regulators factor H, FHL-1, FHR-1, and C4BP. J. Infect. Dis., v. 205, p. 995-1004, 2012.

COUTINHO, M. L. et al. A LigA three-domain region protects hamsters from lethal infection by Leptospira interrogans. PLoS Negl. Trop. Dis., v. 5, p. e1422, 2011.

CHANG, Y. F. et al. Immunogenicity of the recombinant leptospiral putative outer membrane proteins as vaccine candidates. Vaccine, v. 25, p. 8190-8197, 2007.

CHARON, N. W. et al. Antileptospiral activity in lower-vertebrate sera. Infect. Immun., v. 12, p. 1386-1391, 1975.

CHASSIN, C. et al. TLR4- and TLR2-mediated B cell responses control the clearance of the bacterial pathogen, Leptospira interrogans. J. Immunol., v. 183, p. 2669-2677, 2009.

CHIRATHAWORN, C. et al. Binding of Leptospira to extracellular matrix proteins. J. Med. Assoc. Thai., v. 90, p. 2136-2142, 2007.

CHOU, L. F. et al. Sequence of Leptospira santarosai serovar Shermani genome and prediction of virulence-associated genes. Gene, v. 511, p. 364-370, 2012.

CHOY, H. A. Multiple activities of LigB potentiate virulence of Leptospira interrogans: inhibition of alternative and classical pathways of complement. PLoS One, v. 7, p. e41566, 2012.

CHOY, H. A. et al. Physiological osmotic induction of Leptospira interrogans adhesion: LigA and LigB bind extracellular matrix proteins and fibrinogen. Infect. Immun., v. 75, p. 2441-2450, 2007.

CRODA, J. et al.Targeted mutagenesis in pathogenic Leptospira species: disruption of the LigB gene does not affect virulence in animal models of leptospirosis. Infect. Immun., v. 76, p. 5826-5833, 2008.

CULLEN, P. A. et al. Outer membrane proteins of pathogenic spirochetes. FEMS. Microbiol. Rev., v. 28, p. 291-318, 2005.

DAVIS, S. L. et al. SdrG, a fibrinogen-binding bacterial adhesin of the microbial surface components recognizing adhesive matrix molecules subfamily from Staphylococcus epidermidis, targets the thrombin cleavage site in the $\beta$ chain. J. Biol. Chem., v. 276, p. 27799-27805, 2001.

DE FOST, M. et al. Interleukin 12 in part regulates gamma interferon release in human whole blood stimulated with Leptospira interrogans. Clin. Diagn. Lab. Immunol., v. 10, p. 332$335,2003$. 
DE LA PEÑA MOCTEZUMA, A. et al. Comparative analysis of the LPS biosynthetic loci of the genetic subtypes of serovar Hardjo: Leptospira interrogans subtype Hardjoprajitno and Leptospira borgpetersenii subtype Hardjobovis. FEMS. Microbiol. Lett., v. 177, p. 319-326, 1999.

DIAMENT, D. et al. Peripheral blood mononuclear cell activation induced by Leptospira interrogans glycolipoprotein. Infect. Immun., v. 70, p. 1677-1683, 2002.

DOMINGOS, R. F. et al. Features of two proteins of Leptospira interrogans with potential role in host-pathogen interactions. BMC Microbiol., v. 12, n. 50, doi: 10.1186/1471-218012-50, 2012.

EVANGELISTA, K. V.; COBURN, J. Leptospira as an emerging pathogen: a review of its biology, pathogenesis and host immune responses. Future Microbiol., v. 5, n. 9, p. 1413$1425,2010$.

ELLINGHAUSEN, H. C. J.; MC CULLOUGH, W. G. Nutrition of Leptospira Pomona and growth of 13 other serotypes: fractionation of oleic albumin complex and a medium of bovine albumin and polysorbate 80. Am. J. Vet. Res., v. 26, p. 45-51, 1965.

FAINE, S. et al. Leptospire and Leptospirosis. Melbourne, Australia: MediSci, 1999.

FAISAL, S. M. et al. Leptospira immunoglobulin-like protein A variable region (LigAvar) incorporated in liposomes and PLGA microspheres produces a robust immune response correlating to protective immunity. Vaccine, v. 27, p. 378-387, 2009a

FAISAL, S. M. et al. Immune response and prophylactic efficacy of smegmosomes in a hamster model of leptospirosis. Vaccine, v. 27, p. 6129-6136, $2009 \mathrm{~b}$.

FAISAL, S. M. et al. Leptosome-entrapped leptospiral antigens conferred significant higher levels of protection than those entrapped with PC-liposomes in a hamster model. Vaccine, v. 27 , p. 6537-6545, 2009c.

FAISAL, S. M. et al. Evaluation of protective immunity of Leptospira immunoglobulin like protein A (LigA) DNA vaccine against challenge in hamsters. Vaccine, v. 26, p. 277-287, 2008.

FLANNERY, B. et al. Evaluation of recombinant Leptospira antigen-based enzyme-linked immunosorbent assays for the serodiagnosis of leptospirosis. J. Clin. Microbiol., v. 39, p. 3303-3310, 2001.

FÉLIX, S. R. et al. Subunit approach to evaluation of the immune protective potential of leptospiral antigens. Clin. Vaccine Immunol., v. 12, p. 2026-2030, 2011.

FERNANDES, L. G. et al. OmpL1 is an extracellular matrix- and plasminogen-interacting protein of Leptospira spp. Infect. Immun., v. 80, p.3679-3692, 2012.

FIGUEIRA, C. P. et al. Heterologous expression of pathogen-specific genes ligA and ligB in the saprophyte Leptospira biflexa confers enhanced adhesion to cultured cells and fibronectin. BMC Microbiol., v. 11, p. 129, 2011. 
FINN, R. D. et al. Pfam: clans, web tools and services. Nucleic Acids Res., v. 34, p. 247-251, 2006.

FONSECA, C. A. et al. Leptospira DNA detection for the diagnosis of human leptospirosis. J. Infect., v. 52, p. 15-22, 2006 .

FONSECA, C. A. et al. Polymerase chain reaction in comparison with serological tests for early diagnosis of human leptospirosis. Trop. Med. Int. Health., v. 11, p. 1699-1707, 2006 b.

GASTEIGER, E. et al. ExPASy: The proteomics server for in-depth protein knowledge and analysis. Nucleic. Acids Res., v. 31, p. 3784-3788, 2003.

GATTONI, A. et al. Interferon-gamma: biologic functions and HCV therapy (type I/II) (1 of 2 parts). Clin. Ter., v. 157, p. 377-386, 2006.

GRASSMANN, A. A. et al. Protection against lethal leptospirosis after vaccination with LipL32 coupled or coadministered with the B subunit of Escherichia coli heat-labile enterotoxin. Clin. Vaccine Immunol., v. 19, p. 740-745, 2012.

GÓMEZ, R. M. et al. Putative outer membrane proteins of Leptospira interrogans stimulate human umbilical vein endothelial cells (HUVECS) and express during infection. Microb. Pathog., v. 45, p. 315-322, 2008.

GONZÁLEZ, A. et al. Immunogenicity and protective capacity of Leptospira whole-cell monovalent serogroup Ballum vaccines in hamsters. Rev. Argent. Microbiol., v. 37, p. 169$175,2005$.

GREENFIELD, N. J. Using circular dichroism spectra to estimate protein secondary structure. Nat. Protoc., v. 1, p. 2876-2890, 2006.

GRUBER, A.; ZINGALES, B. Alternative method to remove antibacterial antibodies from antisera used for screening of expression libraries. Biotechniques, v. 19, p. 28-30, 1995.

GUO, Y. J. et al. Identification of an HLA-A*0201-restricted CD8 ${ }^{+}$T-cell epitope encoded within Leptospiral immunoglobulin-like protein A. Microbes and Infection, v. 12, p. 364$373,2010$.

HAAKE, D. A. et al. Hamster model of leptospirosis. In: Current protocols in microbiology. New Jersey, EUA: John wiley \& Sons, Inc, 2006. Online .Cap. 12, Unit 12E.2. Disponível em: <http://onlinelibrary.wiley.com/doi/10.1002/9780471729259>. Acesso em: 20 fev. 2013.

HAAKE, D. A. et al. The leptospiral major outer membrane protein LipL32 is a lipoprotein expressed during mammalian infection. Infect. Immun., v. 68, p. 2276-2285, 2000.

HAAKE, D. A. et al. Leptospiral outer membrane proteins OmpL1 and LipL41 exhibit synergistic immunoprotection. Infect. Immun., v. 67, p. 6572-6582, 1999.

HAAKE, D. A.; LOVETT, M. A. Interjunctional invasion of endothelial cell monolayers. Methods Enzymol., v. 236, p. 447-463, 1994. 
HABARTA, A. et al. Increased immunogenicity to LipL32 of Leptospira interrogans when expressed as a fusion protein with the cholera toxin B subunit. Curr. Microbiol., v. 62, p. 526-531, 2010.

HAMBURGUER, Z. A. et al. Crystal structure of invasin: a bacterial integrin-binding protein. Science, v. 286, p. 291-295, 1999.

HANAHAN, D. Studies on transformation of Escherichia coli with plasmids. J. Mol. Biol., v. 166, p. 557-580, 1983.

KAPLAN, E. L.; MEIER, P. Nonparametric estimation from incomplete data. J. Am. Stat. Assoc., v. 53, p. 457-481, 1958.

HARTSKEERL, R. A. International Leptospirosis Society: objectives and achievements. Rev. Panam. Salud Publica, v. 57, n. 1, p. 7-10, 2005.

HAUK, P. T. Caracterizações biológicas das proteínas LipL32 e HlyX de Leptospira interrogans sorovar Copenhageni. 2009. 166 f. Tese (Doutorado em Biotecnologia) Instituto de Ciências Biomédicas, Universidade de São Paulo, São Paulo, 2009.

HAUK, P. et al. In LipL32, the major leptospiral lipoprotein, the $\mathrm{C}$ terminus is the primary immunogenic domain and mediates interaction with collagen IV and plasma fibronectin. Infect. Immun., v. 76, p. 2642-2650, 2009.

HAWIGER, J. et al. Identification of a region of human fibrinogen interacting with staphylococcal clumping factor. Biochemistry, v. 21, p. 1407-1413, 1982.

HOKE, D. E. et al. LipL32 is an extracellular matrix-interacting protein of Leptospira spp. and Pseudoalteromonas tunicata. Infect. Immun., v. 76, p. 2063-2069, 2008.

HOLT, S. C. Anatomy and chemistry of spirochetes. Microbiol. Rev., v. 42, p. 114-160, 1978.

ISOGAI, E. et al. Apoptosis of lymphocytes in mice administered lipopolysaccharide from Leptospira interrogans. Zentralbl Veterinarmed B, v. 45, p. 529-537, 1998.

ITO, T.; YANAGAWA, R. Leptospiral attachment to extracellular matrix of mouse fibroblast (L929) cells. Vet. Microbiol., v. 15, p. 89-96, 1987.

JOHNSON, R. C.; HARRIS, V. G. Differentiation of pathogenic and saprophytic leptospires. I. Growth at low temperatures. J. Bacteriol., v. 94, p. 27-31. 1967.

JOHNSON, W. C. J. Protein secondary structure and circular dichroism: a practical guide. Proteins, v. 7, p. 205-214, 1990.

JOST, B. H. et al. A monoclonal antibody reacting with a determinant on leptospiral lipopolysaccharide protects guinea pigs against leptospirosis. J. Med. Microbiol., v. 22, p. 269-275, 1986.

JUNCKER, A. S. et al. Prediction of lipoprotein signal peptides in Gram-negative bacteria. Protein. Sci., v. 12, p. 1652-1662, 2003. 
KLIMPEL, G. R. et al. Leptospira interrogans activation of human peripheral blood mononuclear cells: preferential expansion of TCR gamma delta+ T cells vs TCR alpha beta+ T cells. J. Immunol., v. 171, p. 1447-1455, 2003.

KELLY, S. M. et al. How to study proteins by circular dichroism. Biochim. Biophys. Acta, v. 1751, p. 119-139, 2005.

KO, A. et al. Urban epidemic of severe leptospirosis in Brazil. Salvador Leptospirosis Study Group. Lancet, v. 354, p. 820-825, 1999.

$\mathrm{KO}$, A. et al. Leptospira: the dawn of the molecular genetics era for an emerging zoonotic pathogen. Nat. Rev. Microbiol., v. 7, n. 10, p. 736-747, 2009.

KOBAYASHI, Y. Human leptospirosis: Management and prognosis. J. Postgrad. Med., v. 51, p. 201-204, 2005.

KOIZUMI, N. et al. A new loop-mediated isothermal amplification method for rapid, simple, and sensitive detection of Leptospira spp. in urine. J. Clin. Microbiol., v. 50, p. 2072-2074, 2012.

KOIZUMI, N.; WATANABE, H. Leptospirosis vaccines: Past, present, and future. J. Postgrad. Med., v. 51, p. 210-214, 2005.

KOIZUMI, N; WATANABE, H. Leptospiral immunoglobulin-like proteins elicit protective immunity. Vaccine, v. 22, p. 1545-1552, 2004.

KOIZUMI, N. et al. [A case of leptospirosis diagnosed early by flaB-PCR]. Kansenshogaku Zasshi., v. 77, p. 627-630, 2003.

KOSITANONT, U. et al. Detection and differentiation between pathogenic and saprophytic Leptospira spp. by multiplex polymerase chain reaction. Diagn. Microbiol. Infect. Dis., v. 57, p. 117-122, 2007.

LÄHTEENMÄKI, K. et al. Bacterial plasminogen activators and receptors. FEMS Microbiol. Rev., v. 25, p. 531-552, 2001.

LAMBERT, A. et al. FlaA proteins in Leptospira interrogans are essential for motility and virulence but are not required for formation of the flagellum sheath. Infect. Immun., v. 80, p. 2019-2025, 2012.

LARKIN, M. A. et al. Clustal W and Clustal X version 2.0. Bioinformatics, v. 23, p. 29472948, 2007.

LEBECH, A. M. et al. Polymerase chain reaction in diagnosis of Borrelia burgdorferi infections and studies on taxonomic classification. APMIS. Suppl., v. 105, p. 1-40, 2002.

LETUNIC, I. et al. SMART 7: recent updates to the protein domain annotation resource. Nucleic. Acids. Research., v. 40, p. D302-D305, 2012.

LEVETT, P. N. et al. Leptospira broomii sp. nov., isolated from humans with leptospirosis. Int. J. Syst. Evol. Microbiol., v. 56, p. 671-673, 2006. 
LEVETT, P. N. et al. Detection of pathogenic leptospires by real-time quantitative PCR. J. Med. Microbiol., v. 54, p. 45-49, 2005.

LEVETT, P. N. Leptospirosis. Clin. Microbiol. Rev. Apr., v. 14, p. 296-326, 2001.

LI, S. et al. Replication or death: distinct fates of pathogenic Leptospira strain Lai within macrophages of human or mouse origin. Innate Immun., v. 16, p. 80-92. 2010.

LIAO, S. et al. Inactivation of the fliY gene encoding a flagellar motor switch protein attenuates mobility and virulence of Leptospira interrogans strain Lai. BMC Microbiol., v. 9, n. 253. doi: 10.1186/1471-2180-9-253, 2009.

LIN, X. et al. Characterization of Conserved Combined T and B Cell Epitopes in Leptospira interrogans Major Outer Membrane Proteins OmpL1 and LipL41. BMC Microbiology, v. 11, p. 21, 2011.

LIN, X. et al. Application of a loop-mediated isothermal amplification method for the detection of pathogenic Leptospira. Diagn. Microbiol. Infect. Dis., v. 63, p. 237-242, 2009c.

LIN, Y. P. et al. Leptospira immunoglobulin-like protein B ( $\operatorname{LigB})$ binding to the C-terminal fibrinogen $\alpha \mathrm{C}$ domain inhibits fibrin clot formation, platelet adhesion and aggregation. Mol. Microbiol., v. 79, p. 1063-1076, 2011.

LIN, Y. P. et al. Repeated domains of leptospira immunoglobulin-like proteins interact with elastin and tropoelastin. J. Biol. Chem., v. 284, p. 19380-19391, 2009a.

LIN, Y. P. et al. Fibronectin binds to and induces conformational change in a disordered region of leptospiral immunoglobulin-like protein B. J. Biol. Chem., v. 284, p. 23547-23557, 2009 b.

LIN, Y. P. et al. Calcium binds to leptospiral immunoglobulin-like protein, LigB, and modulates fibronectin binding. J. Biol. Chem., v. 283, p. 25140-25149, 2008.

LIN, Y. P.; CHANG, Y. F. The C-terminal variable domain of LigB from Leptospira mediates binding to fibronectin. J. Vet. Sci., v. 9, p. 133-144, 2008.

LIN, Y. P.; CHANG, Y. F. A domain of the Leptospira LigB contributes to high affinity binding of fibronectin. Biochem. Biophys. Res. Commun., v. 362, p. 443-448, 2007.

LINGAPPA, J. et al. HLA-DQ6 and ingestion of contaminated water: possible geneenvironment interaction in an outbreak of Leptospirosis. Genes Immun., v. 5, p. 197-202, 2004.

LIU, Y. et al. Pathogenesis of leptospirosis: interaction of Leptospira interrogans with in vitro cultured mammalian cells. Med. Microbiol. Immunol., v. 196, p. 233-239, 2007.

LONGHI, M. T. et al. A newly identified protein of Leptospira interrogans mediates binding to laminin. J. Med. Microbiol., v. 58, p. 1275-1282, 2009.

LOURDAULT, K. et al. Inactivation of clpB in the Pathogen Leptospira interrogans reduces virulence and resistance to stress conditions. Infect. Immun., v. 79, p. 3711-3717, 2011. 
LOURDAULT, K. et al. Use of quantitative real-time PCR for studying the dissemination of Leptospira interrogans in the guinea pig infection model of leptospirosis. J. Med. Microbiol., v. 58, p. 648-655, 2009.

LUCAS, D. L. et al. Recombinant LipL32 and LigA from Leptospira are unable to stimulate protective immunity against leptospirosis in the hamster model. Vaccine, v. 29, p. 3413-3418, 2011.

LUO, D. et al. InvA protein is a nudix hydrolase required for infection by pathogenic Leptospira in cell lines and animals. J. Biol. Chem., v. 286, p. 36852-36863, 2011.

LUO, Y. et al. Crystal structure of enteropathogenic Escherichia coli intimin-receptor complex. Nature, v. 405, p. 1073-1077, 2000.

MALMSTRÖM, J. et al. Proteome-wide cellular protein concentrations of the human pathogen Leptospira interrogans. Nature, v. 460, p. 762-765, 2009.

MARTÍNEZ, R. et al. Efficacy and safety of a vaccine against human leptospirosis in Cuba. Rev. Panam. Salud Publica, v. 15, p. 249-255, 2004.

MATSUNAGA, J. et al. Pathogenic Leptospira species express surface-exposed proteins belonging to the bacterial immunoglobulin superfamily. Mol. Microbiol., v. 49, p. 929-945, 2003.

MC BRIDE, A. J. Leptospirosis. Curr. Opin. Infect. Dis., v. 18, p. 376-386, 2005.

MEITES, E. et al. Reemerging leptospirosis, California. Emerg. Infect. Dis., v. 10, p. 406412, 2004.

MENDES, R. S. et al. The novel leptospiral surface adhesin Lsa20 binds laminin and human plasminogen and is probably expressed during infection. Infect. Immun., v. 79, p. 46574667, 2011.

MERI, T. et al. Regulation of complement activation at the C3-level by serum resistant leptospires. Microb. Pathog., v. 39, p. 139-147, 2005.

MERIEN, F. et al. A rapid and quantitative method for the detection of Leptospira species in human leptospirosis. FEMS. Microbiol. Lett., v. 249, p. 139-147, 2005.

MERIEN, F. et al. Identification of a $36-\mathrm{kDa}$ fibronectin-binding protein expressed by a virulent variant of Leptospira interrogans serovar icterohaemorrhagiae. FEMS. Microbiol. Lett., v. 185, p. 17-22, 2000.

MERIEN, F. et al. In vivo apoptosis of hepatocytes in guinea pigs infected with Leptospira interrogans serovar icterohaemorrhagiae. FEMS. Microbiol. Lett., v. 169, p. 95-102, 1998.

MERIEN, F. et al. Invasion of Vero cells and induction of apoptosis in macrophages by pathogenic Leptospira interrogans are correlated with virulence. Infect. Immun., v. 65, p. 729-738, 1997.

MERIEN, F. et al. Comparison of polymerase chain reaction with microagglutination test and culture for diagnosis of leptospirosis. J. Infect. Dis., v. 172, p. 281-285, 1995. 
MONAHAN, A. M. et al. Review paper: Host-pathogen interactions in the kidney during chronic leptospirosis. Vet. Pathol., v. 46, p. 792-799, 2009.

MORGAN, J. et al. Outbreak of Leptospirosis among Triathlon Participants and Community Residents in Springfield, Illinois. Clin. Infect. Dis., v. 34, n. 12, p. 1593- 1599, 1998.

MORI, Y.; NOTOMI, T. Loop-mediated isothermal amplification (LAMP): a rapid, accurate, and cost-effective diagnostic method for infectious diseases. J. Infect. Chemother., v. 15, p. 62-69, 2009.

MURRAY, G. L. et al. Mutations affecting Leptospira interrogans lipopolysaccharide attenuate virulence. Mol. Microbiol., v. 78, p. 701-709, 2010.

MURRAY, G. L. et al. Genome-wide transposon mutagenesis in pathogenic Leptospira species. Infect. Immun., v. 77, p. 810-816, 2009a.

MURRAY, G. L. et al. Leptospira interrogans requires heme oxygenase for disease pathogenesis. Microbes Infect., v.11, p. 311-314, 2009 b.

MURRAY, G. L. et al. Major surface protein LipL32 is not required for either acute or chronic infection with Leptospira interrogans. Infect. Immun., v. 77, p. 952-958, 2009c.

MURRAY, G. L. et al. Genome-wide transposon mutagenesis in pathogenic Leptospira species. Infect. Immun., v. 77, p. 810-816, 2009d.

MYINT, K. S. et al. Leptospirosis in Kamphaeng Phet, Thailand. Am. J. Trop. Med. Hyg., v.76, p. 135-138, 2007.

NABITY, S. A. et al. Accuracy of a dual path platform (DPP) assay for the rapid point-ofcare diagnosis of human leptospirosis. PLoS. Negl. Trop. Dis., v. 6, p. e1878, 2012.

NAHORI, M. A. et al. Differential TLR recognition of leptospiral lipid A and lipopolysaccharide in murine and human cells. J. Immunol., v. 175, p. 6022-6031, 2005.

NAIMAN, B. M. et al. Evaluation of type 1 immune response in naïve and vaccinated animals following challenge with Leptospira borgpetersenii serovar Hardjo: involvement of WC1(+) gammadelta and CD4 T cells. Infect. Immun., v. 70, p. 6147-6157, 2002.

NAKAI, K.; KANEHISA, M. Expert system for predicting protein localization sites in gram negative bacteria. Proteins, v. 11, p. 95-110, 1991.

NALLY, G. E. et al. Alveolar septal deposition of immunoglobulin and complement parallels pulmonary hemorrhage in a guinea pig model of severe pulmonary leptospirosis. Am. J. Pathol., v. 164, p. 1115-1127, 2004.

NASCIMENTO, A. L. et al. Comparative genomics of two Leptospira interrogans serovars reveals novel insights into physiology and pathogenesis. J. Bacteriol., v. 186, p. 2164-2172, 2004a.

NASCIMENTO, A. L. et al. Genome features of Leptospira interrogans serovar Copenhageni, Braz. J. Med. Biol. Res., v. 37, p. 459-477, 2004b. 
NARITA, M. et al. Leptospirosis after recreational exposure to water in the Yaeyama islands, Japan. Am. J. Trop. Med. Hyg., v. 73, n. 4, p. 652-656, 2005.

NEVES, F. O. et al. Identification of a novel potential antigen for early-phase serodiagnosis of leptospirosis. Arch. Microbiol., v. 188, p. 523-532, 2007.

OLIVEIRA, R. et al. Characterization of novel OmpA-like protein of Leptospira interrogans that binds extracellular matrix molecules and plasminogen. PLoS One, v. 6, p. e21962, 2011.

OLIVEIRA, T. R. et al. LipL53, a temperature regulated protein from Leptospira interrogans that binds to extracellular matrix molecules. Microbes Infect., v. 12, p. 207-217, 2010.

OLIVEIRA, T. R. et al. Evaluation of leptospira recombinant antigens MPL17 and MPL21 for serological diagnosis of leptospirosis by enzyme-linked immunosorbent assays. Clin. Vaccine Immunol., v. 15, p. 1715-1722, 2008.

PALANIAPPAN, R. U. et al. Immunoprotection of recombinant leptospiral immunoglobulinlike protein A against Leptospira interrogans serovar Pomona infection. Infect. Immun., v. 74, p. 1745-1750, 2006.

PALANIAPPAN, R. U. et al. Evaluation of lig-based conventional and real time PCR for the detection of pathogenic leptospires. Mol. Cell. Probes., v. 19, p. 111-117, 2005.

PALANIAPPAN, R. U. et al. Cloning and molecular characterization of an immunogenic LigA protein of Leptospira interrogans. Infect. Immun., v. 70, p. 5924-5930, 2002.

PAPPAS, G. et al. The globalization of leptospirosis: worldwide incidence trends. Int. J. Infect. Dis., v. 12, n. 4, p. 351-357, 2008.

PATHIRANA, R. D. et al. Characterization of proteinase-adhesin complexes of Porphyromonas gingivalis. Microbiology (Reading, England), v. 152, p. 2381-2394, 2006.

PASTER, B. J. et al. Phylogenetic analysis of the spirochetes. J. Bacteriol., v. 173, n. 19, p. 6101-6109, 1991.

PEREZ-IRATXETA, C.; ANDRADE-NAVARRO, M. A. K2D2: estimation of protein secondary structure from circular dichroism spectra. BMC Structural Biology, v. 8, p. 25. 2008.

PEROLAT, P. et al. Leptospira fainei sp. nov., isolated from pigs in Australia. Int. J. Syst. Bacteriol., v. 48, pt. 3, p. 851-858, 1998.

PETERSEN, T. N. et al. SignalP 4.0: discriminating signal peptides from transmembrane regions. Nature Methods., v. 8, p. 785-786, 2011.

PICARDEAU, M. et al. First evidence for gene replacement in Leptospira spp. Inactivation of L. biflexa flaB results in non-motile mutants deficient in endoflagella. Mol. Microbiol., v. 40, p. 189-199, 2001.

PICARDEAU, M. et al. Genome sequence of the saprophyte Leptospira biflexa provides insights into the evolution of Leptospira and the pathogenesis of leptospirosis. PLoS One, v. 3, p. e1607, 2008. 
PINNE, M. et al. The OmpL37 surface-exposed protein is expressed by pathogenic Leptospira during infection and binds skin and vascular elastin. PLoS Negl. Trop. Dis., v. 4, p. e815, 2010.

PLANK, R.; DEAN, D. Overview of the epidemiology, microbiology, and pathogenesis of Leptospira spp. in humans. Microbes Infect., v. 2, p. 1265-1276, 2000.

PRETRE, G. et al. Characterization of LIC11207, a novel leptospiral protein that is recognized by human convalescent sera and prevents apoptosis of polymorphonuclear leukocytes. Microb. Pathog., v. 56, p. 21-28, 2013.

QUE-GEWIRTH, N. L. et al. A methylated phosphate group and four amide-linked acyl chains in Leptospira interrogans lipid A. The membrane anchor of an unusual lipopolysaccharide that activates TLR2. J. Biol. Chem., v. 279, p. 25420-25429, 2004.

RAMOS, C. R. R. et al. A high-copy T7 Escherichia coli expression vector for the production of recombinant proteins with a minimal N-terminal His-tagged fusion peptide. Braz. J. Med. Biol. Res., v. 37, p. 1103-1109, 2004.

RATHINAM, S. R. et al. Uveitis associated with an epidemic outbreak of leptospirosis. Am. J. Ophthalmol., v. 124, p. 71-79, 1997.

REN, S. X. et al. Unique physiological and pathogenic features of Leptospira interrogans revealed by whole-genome sequencing. Nature, v. 422, p. 888-893, 2003.

RICALDI, J. N. et al. Whole genome analysis of Leptospira licerasiae provides insight into leptospiral evolution and pathogenicity. PLoS Negl. Trop. Dis. v. 6, p.e1853, 2012.

RISTOW, P. et al. Biofilm formation by saprophytic and pathogenic leptospires. Microbiology, v. 154, p. 1309-1317, 2008.

RISTOW, P. et al. The OmpA-like protein Loa22 is essential for leptospiral virulence. PLoS Pathog., v. 3, p. e97, 2007.

RUGMAN, F. P. et al. Anticardiolipin antibodies in leptospirosis. J. Clin. Pathol., v. 44, p. 517-519, 1991.

SAMBROOK, J. et al. Molecular cloning: a laboratory manual. 2nd ed. Cold Spring Harbor: Cold Spring Harbor Laboratory Press, 1989.

SASAKI, D. M. et al. Active surveillance and risk factors for leptospirosis in Hawaii. Am. J. Trop. Med. Hyg., v. 48, p. 35-43, 1993.

SCHRÖDER, N. W. et al. Immune responses induced by spirochetal outer membrane lipoproteins and glycolipids. Immunobiology, v. 213, n. 3-4, p. 329-340, 2008.

SEIXAS, F. K. et al. Recombinant Mycobacterium bovis BCG expressing the LipL32 antigen of Leptospira interrogans protects hamsters from challenge. Vaccine, v. 26, p. 88-95, 2007.

SETUBAL, J. C. et al. Lipoprotein computational prediction in spirochaetal genomes. Microbiology, v. 152, p. 113-121, 2006. 
SILVA, E. F. et al. The terminal portion of leptospiral immunoglobulin-like protein LigA confers protective immunity against lethal infection in the hamster model of leptospirosis. Vaccine, v. 25, p. 6277-6286, 2007.

SLACK, A. et al. Evaluation of a modified Taqman assay detecting pathogenic Leptospira spp. against culture and Leptospira-specific IgM enzyme-linked immunosorbent assay in a clinical environment. Diagn. Microbiol. Infect. Dis., v. 57, p. 361-366, 2007.

SLACK, A. T. et al. Identification of pathogenic Leptospira species by conventional or realtime PCR and sequencing of the DNA gyrase subunit B encoding gene. BMC Microbiol., v. 6, p. 95, 2006.

SLAMTI, L. et al. Deciphering morphological determinants of the helix-shaped Leptospira. J. Bacteriol., v. 193, p. 6266-6275, 2011.

SMYTHE, L. et al. Classification of Leptospira genomospecies 1, genomospecies 3, genomospecies 4 and genomospecies 5 as Leptospira alstonii sp. nov., Leptospira vanthielii sp. nov., Leptospira terpstrae sp. nov., Leptospira yanagawae sp. nov., respectively. Int. J. Syst. Evol. Microbiol., 2012. Epub ahead of print.

SMYTHE, L. et al. Classification of Leptospira genomospecies 1, genomospecies 3, genomospecies 4 and genomospecies 5 as Leptospira alstonii sp. nov., Leptospira vanthielii sp. nov., Leptospira terpstrae sp. nov., Leptospira yanagawae sp. nov., respectively. Int. J. Syst. Evol. Microbiol., 2012. Epub ahead of print.

SMYTHE, L. D. et al. A quantitative PCR (TaqMan) assay for pathogenic Leptospira spp. BMC Infect. Dis., v. 2, p. 13, 2002.

SONHAMMER, E. L. L. et al. Pfam: a comprehensive database of protein families based on seed alignments. Proteins, v. 28, p. 405-420, 1997.

SONTHAYANON, P. et al. Accuracy of loop-mediated isothermal amplification for diagnosis of human leptospirosis in Thailand. Am. J. Trop. Med. Hyg., v. 84, p. 614-620, 2011.

SOUZA, N. M. et al. Lsa30, a novel adhesin of Leptospira interrogans binds human plasminogen and the complement regulator C4bp. Microb. Pathog., v. 53, p. 125-134, 2012.

SOUZA, V. M. et al. Years of potential life lost and hospitalization costs associated with leptospirosis in Brazil. Rev. Saude Publica, v. 45, p. 1001-1008, 2011.

STARK, K. et al. [Climate changes and emerging diseases. What new infectious diseases and health problem can be expected?]. Bundesgesundheitsblatt Gesundheitsforschung Gesundheitsschutz, v. 54, p. 699-714, 2009.

STERN, E. J. et al. Outbreak of leptospirosis among Adventure Race participants in Florida, 2005. Clin. Infect. Dis., v. 50, n. 6, p. 843-849, 2010.

STEVENSON, B. et al. Leptospira interrogans endostatin-like outer membrane proteins bind host fibronectin, laminin and regulators of complement. PLoS One, v. 2, p. e1188, 2007. 
STODDARD, R. A. et al. Detection of pathogenic Leptospira spp. through TaqMan polymerase chain reaction targeting the LipL32 gene. Diagn. Microbiol. Infect. Dis., v. 64, p. 247-255, 2009.

STUDIER, F. W. Use of bacteriophage T7 lysozyme to improve an inducible T7 expression system. J. Mol. Biol., v. 219, p. 37-44, 1991.

STUDIER, F. W. et al. Use of T7 RNA polymerase to direct expression of cloned genes. Methods Enzymol., v. 185, p. 60-89, 1990.

SCHULTZ, J. et al. SMART, a simple modular architecture research tool: Identification of signaling domains. PNAS, v. 95, p. 5857-5864, 1998.

SUWANCHAROEN, D. et al. Development of a novel primer combination to detect pathogenic Leptospira by loop-mediated isothermal amplification. J. Microbiol. Methods., v. 91, p. 171-173, 2012.

TAJIKI, M. H.; SALOMÃO, R. Association of plasma levels of tumor necrosis factor alpha with severity of disease and mortality among patients with leptospirosis. Clin. Infect. Dis., v. 23, p. 1177-1178, 1996.

TOYOKAWA, T.; OHNISHI, M.; KOIZUMI, N. Diagnosis of acute leptospirosis. Expert. Rev. Anti. Infect. Ther., v. 9, p. 111-121, 2011.

THOMAS, D. D.; HIGBIE, L. M. In vitro association of leptospires with host cells. Infect. Immun., v. 58, p. 581-585, 1990.

TRUEBA, G. et al. Cell aggregation: a mechanism of pathogenic Leptospira to survive in fresh water. Int. Microbiol., v. 7, p. 35-40, 2004.

TSINGANOU, E.; GEBBERS, J. O. Human intestinal spirochetosis--a review. Ger. Med. Sci., v. 8, Doc.01, 2010. doi: 10.3205/000090.

VERMA, A. et al. Cross-reactivity of antibodies against leptospiral recurrent uveitisassociated proteins A and B (LruA and LruB) with eye proteins. PLoS Negl. Trop. Dis., v. 4, p. e778, 2010a.

VERMA, A. et al. Leptospiral endostatin-like protein A is a bacterial cell surface receptor for human plasminogen. Infect. Immun., v. 78, p. 2053-2059, 2010 b.

VERMA, A. et al. LruA and LruB antibodies in sera of humans with leptospiral uveitis. Clin. Vaccine Immunol., v. 15, p. 1019-1023, 2008.

VERMA, A. et al. LfhA, a novel factor H-binding protein of Leptospira interrogans. Infect. Immun., v. 74, p. 2659-2666, 2006.

VERNEL-PAUILLAC, F.; GOARANT, C. Differential cytokine gene expression according to outcome in a hamster model of leptospirosis. PLoS Negl. Trop. Dis., v. 4 p. e582, 2010.

VIEIRA, M. L. et al. In vitro evidence for immune evasion activity by human plasmin associated to pathogenic Leptospira interrogans. Microb. Pathog., v. 51, p. 360-365, 2011. 
VIEIRA, M. L. et al. Lsa63, a newly identified surface protein of Leptospira interrogans binds laminin and collagen IV. J. Infect., v. 60, p. 52-64, 2010a.

VIEIRA, M. L. et al. In vitro identification of novel plasminogen binding receptors of the pathogen Leptospira interrogans. PLoS One, v. 5, p. e11259, 2010 b.

VIEIRA, M. L. et al. Plasminogen acquisition and activation at the surface of leptospira species lead to fibronectin degradation. Infect. Immun., v. 77, p. 4092-4101, 2009.

VIEIRA, M. L. et al. A novel leptospiral protein increases ICAM-1 and E-selectin expression in human umbilical vein endothelial cells. FEMS Microbiology Letters, v. 276, p. 172e80, 2007.

VINETZ, J. M. Leptospirosis. Curr. Opin. Infect. Dis., v. 14, n. 5, p. 527-538. 2001.

ZHONG, Y. et al. Comparative proteogenomic analysis of the Leptospira interrogans virulence-attenuated strain IPAV against the pathogenic strain 56601. Cell Res., v. 21, p. 1210-1229, 2011.

WERTS, C. et al. Leptospiral lipopolysaccharide activates cells through a TLR2-dependent mechanism. Nat. Immunol., v. 2, p. 346-352, 2001.

WOLGEMUTH, C. W. et al. The flagellar cytoskeleton of the spirochetes. J. Mol. Microbiol. Biotechnol., v. 11, p. 221-227, 2006.

WORLD HEALTH ORGANIZATION. Human leptospirosis: guidance for diagnosis, surveillance, and control. World Health Organization, Geneva, Switzerland, 2003.

WORLD HEALTH ORGANIZATION. Leptospirosis worldwide, 1999. Wkly. Epidemiol. Rec., v. 74, p. 237-242, 1999.

YAN, C. et al.Toll-like receptor 2 mediates early inflammation by leptospiral outer membrane proteins in proximal tubule cells. Kidney Int., v. 69, p. 815-822, 2006.

YAN, W. et al. Identification and characterization of OmpA-like proteins as novel vaccine candidates for Leptospirosis. Vaccine, v. 28, p. 2277-2283, 2010.

YAN, W. et al. Immunogenicity and protective efficacy of recombinant Leptospira immunoglobulin-like protein B (rLigB) in a hamster challenge model. Microbes Infect., v. 11, p. 230-237, 2009.

YAN, Y. et al. An evaluation of the serological and epidemiological effects of the outer envelope vaccine to leptospira. J. Chin. Med. Assoc., v. 66, p. 224-230. 2003.

YU, C. S. et al. Predicting subcellular localization of proteins for Gram-negative bacteria by support vector machines based on n-peptide compositions. Protein Sci., v. 13, p. 1402-1406, 2004.

YU, C. S. et al. Prediction of protein subcellular localization. Proteins, v. 64, p. 643-651, 2006. 


\section{APÊNDICES}

APÊNDICE A- Alinhamento dos aminoácidos das proteínas codificadas pelos genes LIC11121, LIC11087, LIC11228 e LIC11084 em espécies patogênicas de Leptospira ssp. 


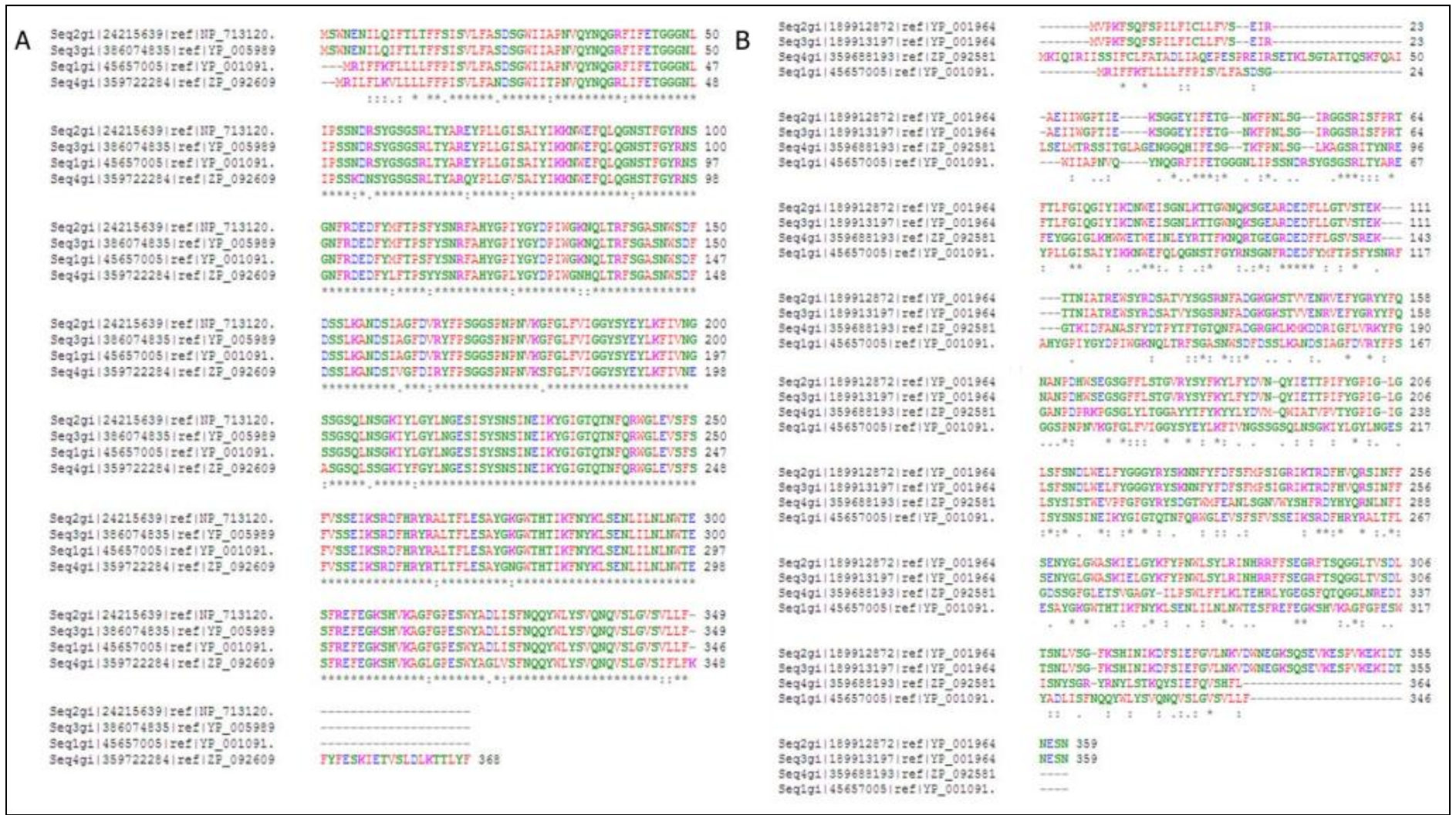

Análise da identidade da proteína hipotética codificada por LIC11121. (A) Alinhamento dos aminoácidos em espécies patogênicas de Leptospira ssp. Seq1 Leptospira interrogans sorovar Copenhageni str. Fiocruz L1-130; Seq2 Leptospira interrogans sorovar Lai str. 56601(Identidade 100\%); Seq3 Leptospira interrogans sorovar Lai str. IPAV (Identidade 100\%);Seq4 Leptospira noguchii str. 2006001870 (Identidade 94\%). (B) Alinhamento dos aminoácidos na espécie saprófita e intermediária. Seq1 Leptospira interrogans sorovar Copenhageni str. Fiocruz L1-130. Seq2 Leptospira biflexa sorovar Patoc strain 'Patoc 1 (Ames) (Identidade 30\%)'; Seq3 Leptospira biflexa sorovar Patoc strain 'Patoc 1 (Paris)' (Identidade 30\%); Seq4 Leptospira licerasiae sorovar Varillal str. MMD0835 (Identidade 29\%). As sequencias foram obtidas no site NCBI (http://www.ncbi.nlm.nih.gov/) e os alinhamentos realizados no programa ClustalW2 (http://www.ebi.ac.uk/Tools/msa/clustalw2/). 
A Seq191/45656971/ ret|YP_001057. Seq2g1/24215674 iret IIIP_-71315:

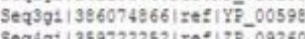
Seg401/359722252/ ret /2P_09260 Seq5g1|116931614| ze! |YP 801332

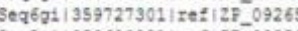

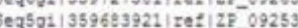

Seq19:145656971|ref IYP 001057 . Seq291 24215674 | ret $\mid 147-713155$. Seq391 1386074666 Iret/Y 00598

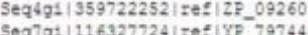

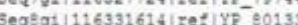
Seq5g1| 359683921 | :eE1 12P_-09253

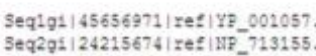
Seq3g1 386074666 | retike 00596 Sequgl 359722252 Iet 28.092609

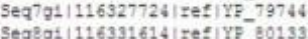

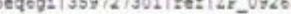
Seq5o1/359683921 | reti2P_09253

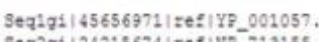

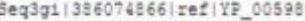

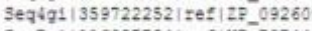

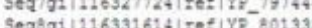

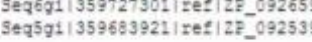

Seq1gi|45656971/ ret|Yz_001057. อ Sezig1 13597222521 ret 128 _092609 Seqาg1 116327724 :ee!|YP 79746

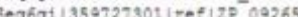

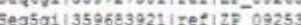

Seq1951 45656971| re: |YP_001057. Seq2q1 24215674 re: IIIP 713159

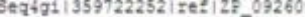

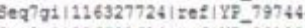

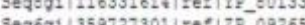

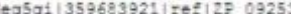

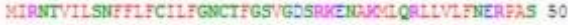

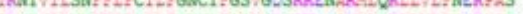

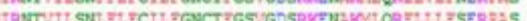
Tom

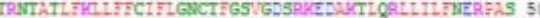

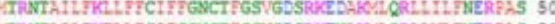

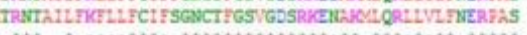

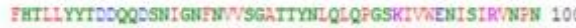

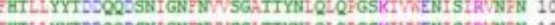

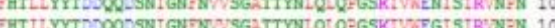

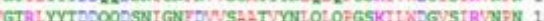

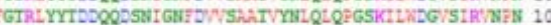

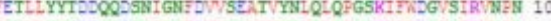

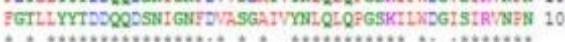

FNFTV:GQRRTIE,GERSTQSHTFYTVPLDLP1SSFYSAEYYTSSIEDSW 150 FFTVFGQTRILZ2GEHSTQSATFYTVPIDLPISSFYSAEYYTSSFZDSM 150

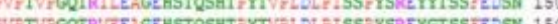

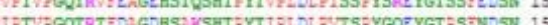
FPTVG

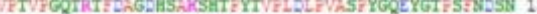

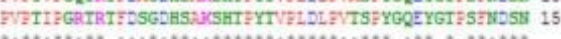

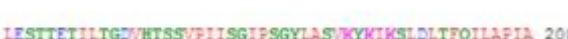
ITrQILAFIa 200 ESITETILTGJVHTSSVEIISGIFSGYLASVKYKIKSLDITEOTLAPIA 20

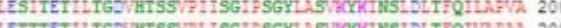

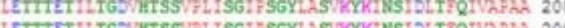

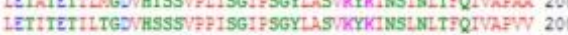

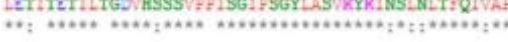

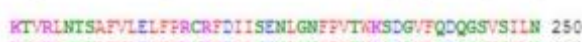

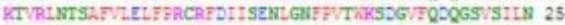

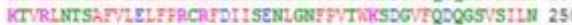

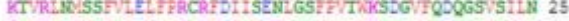

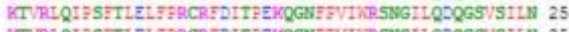

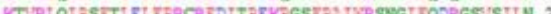

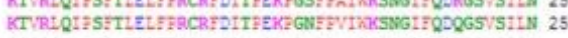

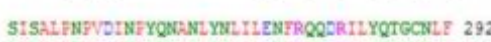

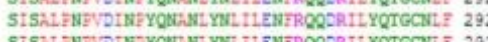

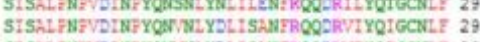

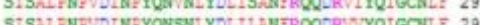

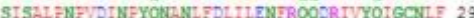

B Seq2g: $|183222465|=E\{\mid Y P, 001840$

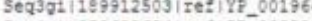

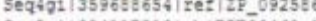

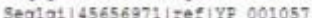

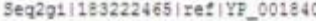

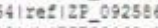
Seq1 191 45656971 | ze: |Y? 001057 .

Seq2g1|1e3222465| re? |YP 001840

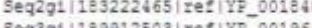

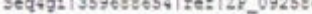

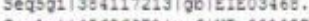
Seq1 1 1/45656971| re: |YP_001057.

Seq2g士 1189222465 | ret/YF 001840 Seq3g1 |199912503| ret |YP_00196:

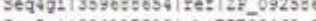

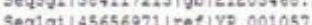

Seq2g1 |183222665 | re? |YP_001960

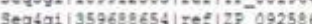
Seq1914.45656971|ret|YP_001057.

Seq2g1 $1193222465 \mid$ ret 1 Y8 001840 Seq3911199912503 I reE!YYZ001964 Sez4g1/35968s654| re? 128_092586 Seq57: 364117213 gh

Seq201 $1183222465 \mid$ ze: $1 Y F_{-} 001840$ Seq3g11169912503 / ret /YP_001964

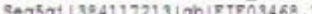
Sex191145636971|re: 1YP 00105 ?

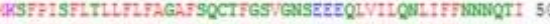

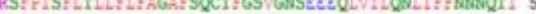

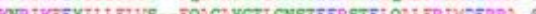

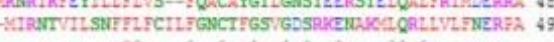

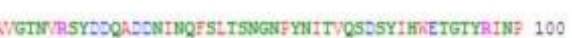

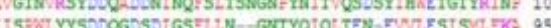

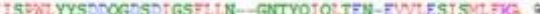

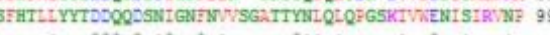

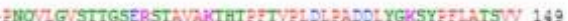

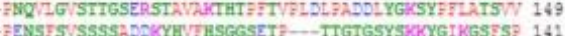

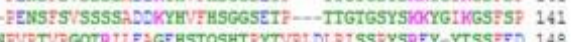

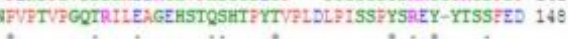

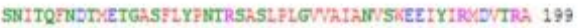

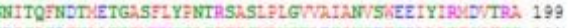
19

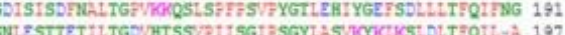

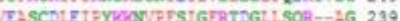

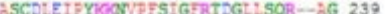

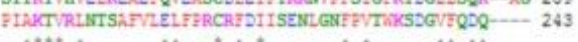

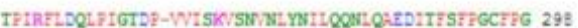

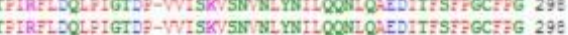

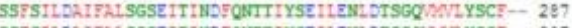

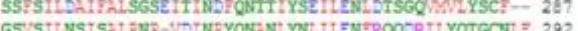

VER 301
VER 301

Análise da identidade da proteína hipotética codificada por LIC11087 (A) Alinhamento dos aminoácidos em espécies patogênicas de Leptospira ssp. Seq1 Leptospira interrogans sorovar Copenhageni str. Fiocruz L1-130; Seq2 Leptospira interrogans sorovar Lai str. 56601(Identidade 100\%);Seq3 Leptospira interrogans sorovar Lai str. IPAV (Identidade 100\%);Seq4 Leptospira noguchii str. 2006001870 (Identidade 94\%); Seq5 Leptospira santarosai str. 2000030832 (Identidade 81\%); Seq6 Leptospira weilii str. 2006001855 (Identidade 79\%); Seq7 Leptospira borgpetersenii sorovar Hardjo-bovis L550 (Identidade 87\%); Seq8 
Leptospira borgpetersenii sorovar Hardjo-bovis JB197 (Identidade 87\%); (B) Alinhamento dos aminoácidos na espécie saprófita e intermediária. Seq1 Leptospira interrogans sorovar Copenhageni str. Fiocruz L1-130; Seq2 Leptospira biflexa sorovar Patoc strain 'Patoc 1 (Paris)' (Identidade 30\%);Seq3 Leptospira biflexa sorovar Patoc strain 'Patoc 1 (Ames)' (Identidade 30\%); Seq4 Leptospira licerasiae sorovar Varillal str. MMD0835 (Identidade 29\%) Seq5 Leptospira licerasiae sorovar Varillal str. VAR 010 (Identidade 29\%). As sequencias foram obtidas no site NCBI (http://www.ncbi.nlm.nih.gov/) e os alinhamentos realizados com programa ClustalW2 (http://www.ebi.ac.uk/Tools/msa/clustalw2/). 


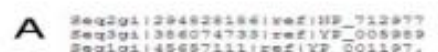

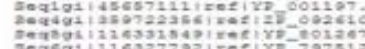

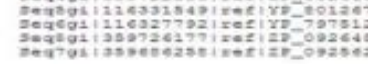

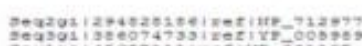

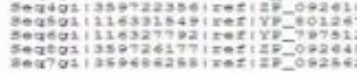

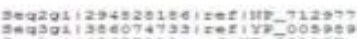

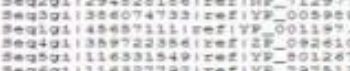

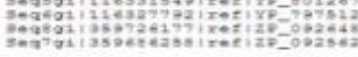

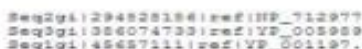

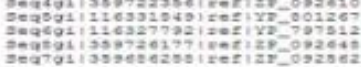

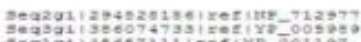

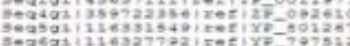

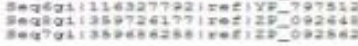

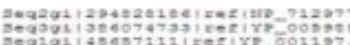

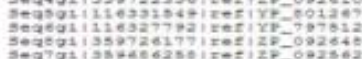

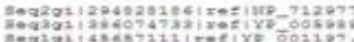

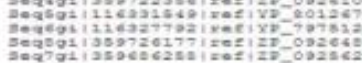

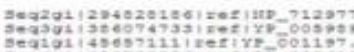

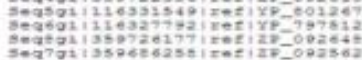

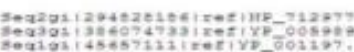

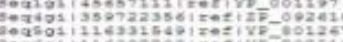
D.
:

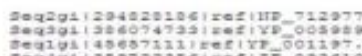

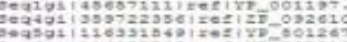

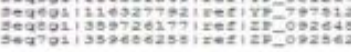
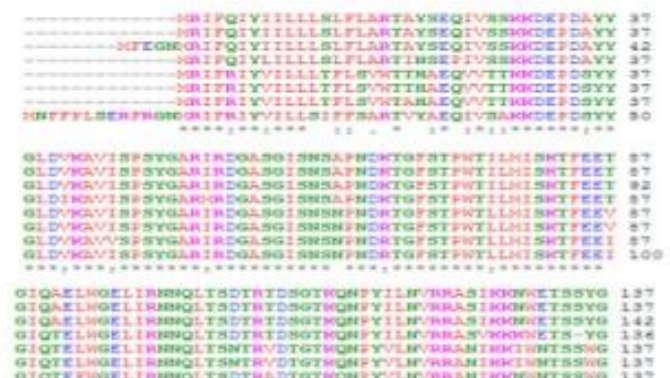

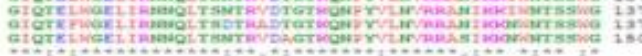

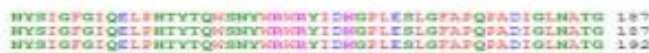

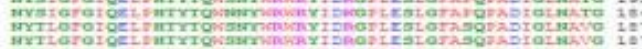

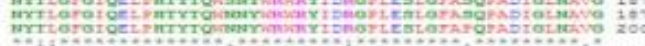

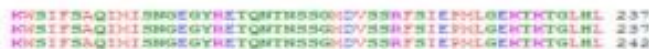

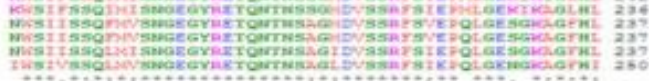

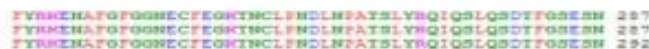

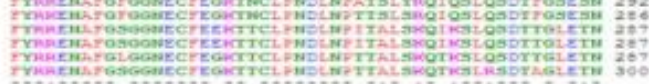

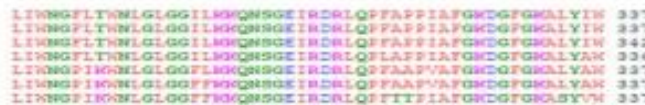

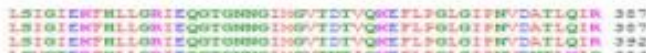

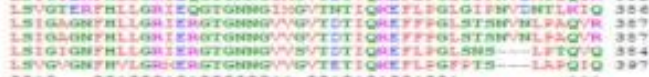

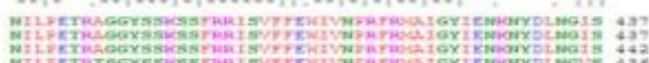

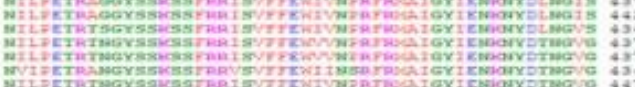

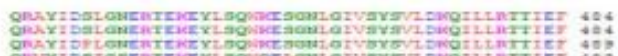

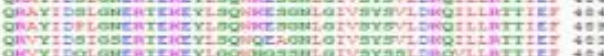

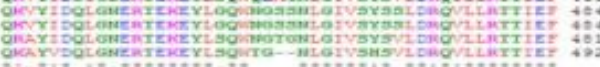

B

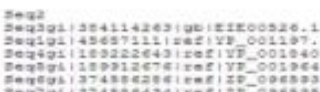

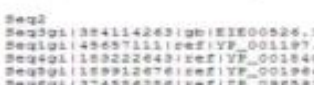

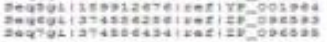

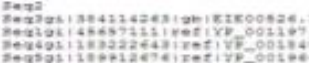

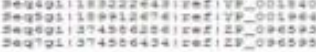

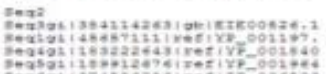

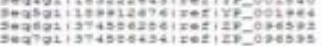

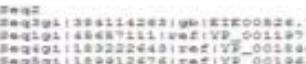

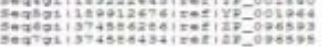

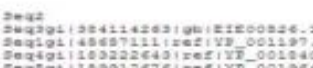

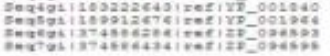

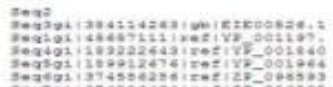

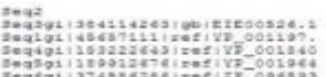

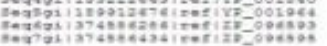

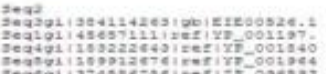

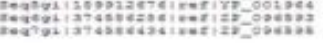

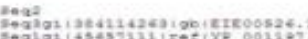

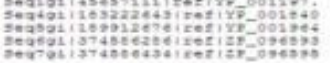

5ag:

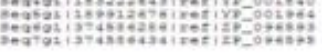

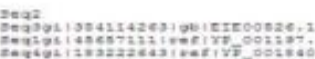

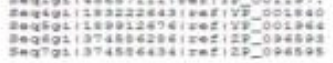

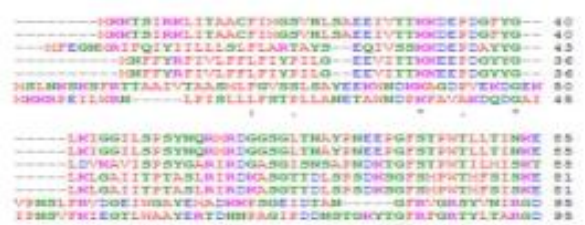

carasion

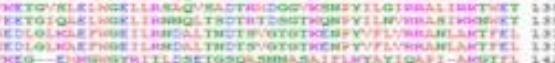
Aing

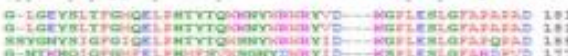

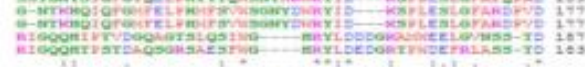

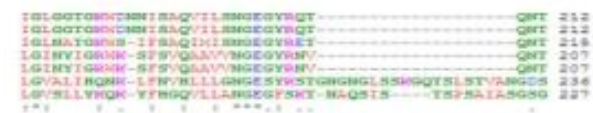

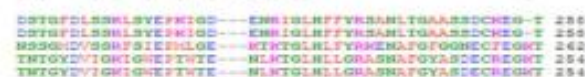

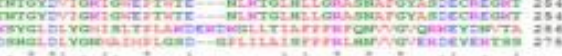
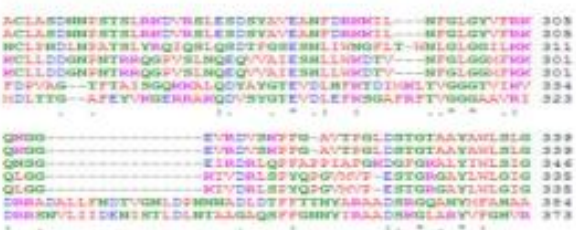

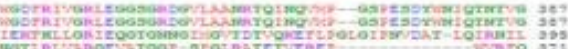

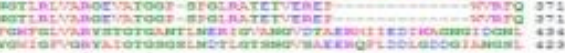

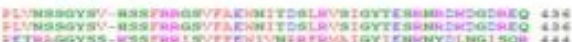
The

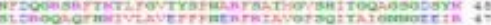

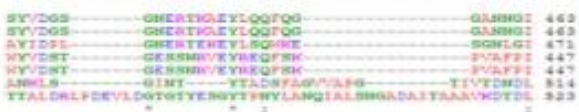

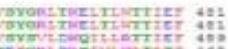

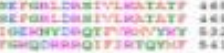

Análise da identidade da proteína hipotética codificada por LIC11228 (A) Alinhamento dos aminoácidos em espécies patogênicas de Leptospira ssp. Seq1 Leptospira interrogans sorovar Copenhageni str. Fiocruz L1-130; Seq2 Leptospira interrogans sorovar Lai str. 56601 (Identidade 99\%); Seq3 Leptospira 
interrogans sorovar Lai str IPAV (Identidade 99\%); Seq4 Leptospira noguchii str. 2006001870 (Identidade 93\%); Seq5 Leptospira borgpetersenii sorovar Hardjo-bovis JB197 (Identidade 80\%); Seq6 Leptospira borgpetersenii sorovar Hardjo-bovis L550 (Identidade 80\%); Seq7 Leptospira santarosai str. 2000030832 (Identidade 80\%); Seq8 Leptospira weilii str. 2006001855 (Identidade 79\%). (B) Alinhamento dos aminoácidos na espécie saprófita e intermediária. Seq1 Leptospira interrogans sorovar Copenhageni str. Fiocruz L1-130; Seq2 Leptospira licerasiae sorovar Varillal str. MMD0835 (Identidade $50 \%$ ); Seq3 Leptospira licerasiae sorovar Varillal str. VAR 010 (Identidade 50\%); Seq4 Leptospira biflexa sorovar Patoc strain 'Patoc 1 (Paris)' (Identidade 41\%); Seq5 Leptospira biflexa sorovar Patoc strain 'Patoc 1 (Ames)' (Identidade 41\%); Seq6 Leptonema illini DSM 21528 (Identidade 22\%) proteína Lepil_2466; Seq7 Leptonema illini DSM 21528 (Identidade 22\%) proteína Lepil_2616. As sequencias foram obtidas no site NCBI (http://www.ncbi.nlm.nih.gov/) e os alinhamentos realizados com programa ClustalW2 (http://www.ebi.ac.uk/Tools/msa/clustalw2/). 


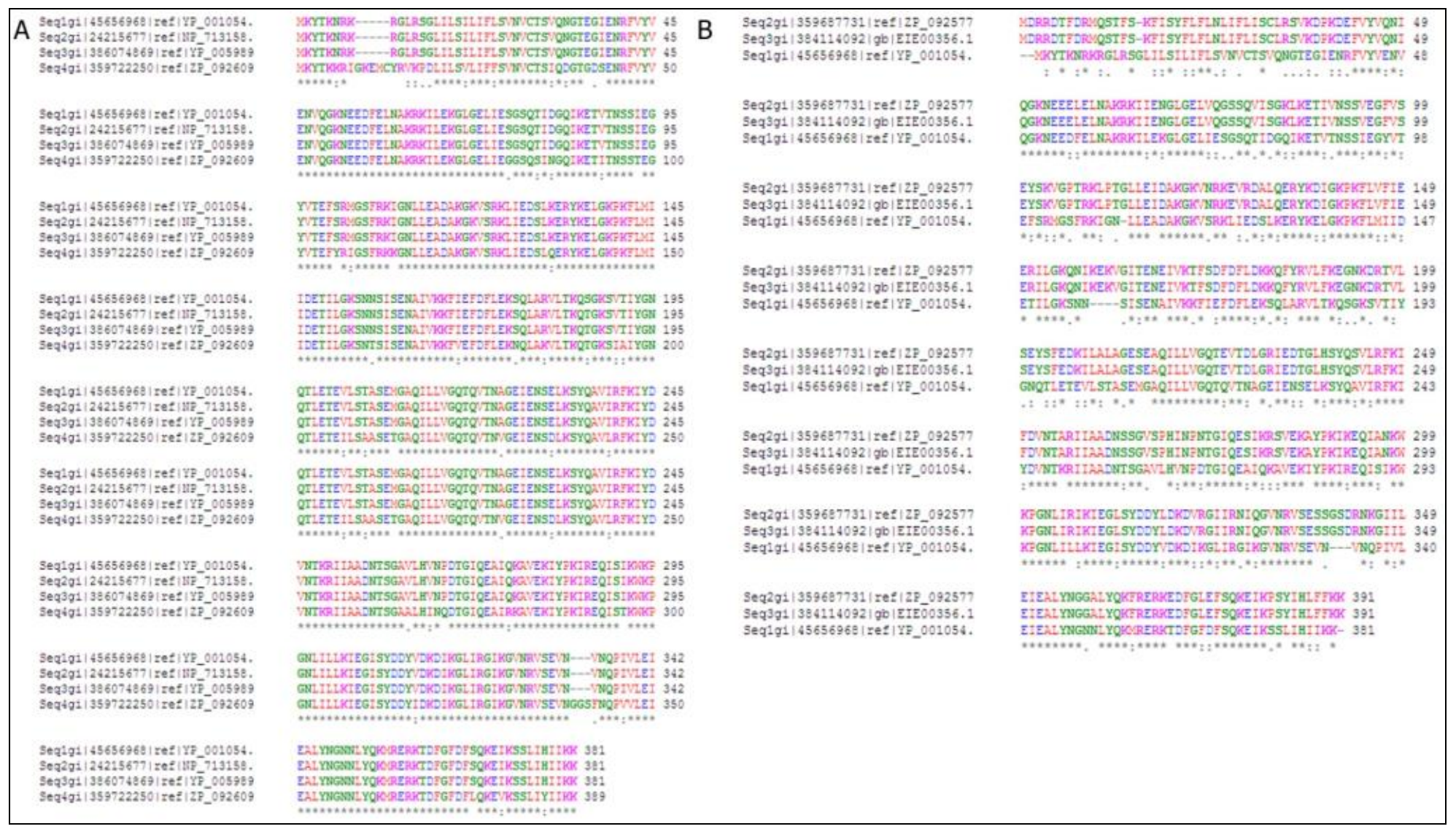

Análise da identidade da proteína hipotética codificada por LIC11084. (A) Alinhamento dos aminoácidos em espécies patogênicas de Leptospira ssp. Seq1 Leptospira interrogans sorovar Copenhageni str. Fiocruz L1-130; Seq2 Leptospira interrogans sorovar Lai str. 56601 (100\%); Seq 3 Leptospira interrogans sorovar Lai str.IPAV (100\%); Seq4 Leptospira noguchii str. 2006001870 (86\%). (B) Alinhamento dos aminoácidos na espécie intermediária Leptospira licerasiae. Seq1 Leptospira interrogans sorovar Copenhageni str. Fiocruz L1-130; Seq2 Leptospira licerasiae sorovar Varillal str. MMD0835 (59\%); Seq3 Leptospira licerasiae sorovar Varillal str. VAR 010 (59\%). As sequencias foram obtidas no site NCBI (http://www.ncbi.nlm.nih.gov/) e os alinhamentos realizados com programa ClustalW2 (http://www.ebi.ac.uk/Tools/msa/clustalw2/). 
APÊNDICE B- Artigo publicado no período de desenvolvimento do mestrado: SOUZA, N.M. et al. Lsa30, a novel adhesin of Leptospira interrogans binds human plasminogen and the complement regulator C4bp. Microb Pathog., v. 53, p. 125-134, 2012. 


\title{
Lsa30, a novel adhesin of Leptospira interrogans binds human plasminogen and the complement regulator C4bp
}

\author{
Natalie M. Souza ${ }^{\mathrm{a}, \mathrm{b}}$, Monica L. Vieira ${ }^{\mathrm{a}, \mathrm{b}}$, Ivy J. Alves ${ }^{\mathrm{a}}$, Zenaide M. de Morais ${ }^{\mathrm{c}}$, Silvio A. Vasconcellos ${ }^{\mathrm{c}}$, \\ Ana L.T.O. Nascimento ${ }^{\mathrm{a}, \mathrm{b}, *}$ \\ ${ }^{a}$ Centro de Biotecnologia, Instituto Butantan, Avenida Vital Brazil, 1500, 05503-900, São Paulo, SP, Brazil \\ b Interunidades em Biotecnologia, Instituto de Ciências Biomédicas, USP, Avenida Prof. Lineu Prestes, 1730, 05508-900, São Paulo, SP, Brazil

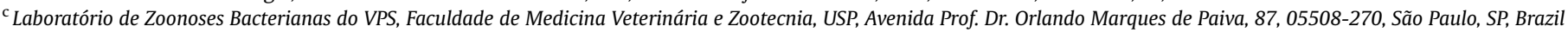

\section{A R T I C L E I N F O}

\section{Article history:}

Received 5 April 2012

Received in revised form

13 June 2012

Accepted 14 June 2012

Available online 23 June 2012

\section{Keywords:}

Leptospira

Leptospirosis

Adhesion

Plasminogen

C4bp

\begin{abstract}
A B S T R A C T
Pathogenic Leptospira is the etiological agent of leptospirosis, a life-threatening disease that affects populations worldwide. Surface proteins have the potential to promote several activities, including adhesion. This work aimed to study the leptospiral coding sequence (CDS) LIC11087, genome annotated as hypothetical outer membrane protein. The LIC11087 gene was cloned and expressed in Escherichia coli BL21 (DE3) strain by using the expression vector pAE. The recombinant protein tagged with N-terminal $6 \mathrm{XHis}$ was purified by metal-charged chromatography and characterized by circular dichroism (CD) spectroscopy. The recombinant protein has the ability to mediate attachment to the extracellular matrix (ECM) components, laminin and plasma fibronectin, and was named Lsa30 (Leptospiral surface adhesin of $30 \mathrm{kDa}$ ). Lsa30 binds to laminin and to plasma fibronectin in a dose-dependent and saturable manner, with dissociation equilibrium constants $\left(K_{D}\right)$ of $292 \pm 24 \mathrm{~nm}$ and $157 \pm 35 \mathrm{~nm}$, respectively. Moreover, the Lsa30 is a plasminogen (PLG) receptor, capable of generating plasmin, in the presence of activator. This protein may interfere with the complement cascade by interacting with C4bp regulator. The Lsa30 is probably a new surface protein of Leptospira as revealed by immunofluorescence assays with living organisms and the reactivity with antibodies present in serum samples of experimentally infected hamsters. Thus, Lsa30 is a novel versatile protein that may play a role in mediating adhesion and may help pathogenic Leptospira to overcome tissue barriers and to escape the immune system.
\end{abstract}

(c) 2012 Elsevier Ltd. All rights reserved.

\section{Introduction}

Leptospirosis is a disease caused by spirochetes of the genus Leptospira that affects animals and humans worldwide. The transmission occurs by direct or indirect contact of humans with urine of infected animals [1]. In the urban surroundings, the disease is associated with the growing population and the lack of appropriate sanitation measures. Each year, more than 500,000 cases are reported with mortality rates that fluctuate between $10 \%$ and $40 \%$ [2]. However, these data are probably underestimated because of the non-specific clinical symptoms of leptospirosis that can vary from flu-like to fatal pulmonary hemorrhage and Weil's syndrome [3]. Effective control strategies are not very efficient since that pathogenesis of the disease is not well understood. Currently

\footnotetext{
* Corresponding author. Interunidades em Biotecnologia, Instituto de Ciências Biomédicas, USP, Avenida Prof. Lineu Prestes, 1730, 05508-900, São Paulo, SP, Brazil. Tel.: +5511 37220019; fax: +5511 37261505

E-mail address: tabet@butantan.gov.br (A.L.T.O. Nascimento).
}

veterinary vaccines against leptospirosis are composed by inactivated whole cells that have drawbacks such as not offering protection against serovars not included in composition. Only China [4] and Cuba [5] have human licensed vaccines with the same limitations as the veterinary ones.

Due to their location, surface proteins are in contact with the host and may be involved in leptospiral infectivity and protective immunity. We have characterized several of these proteins and identified novel leptospiral adhesins that might be involved in the first steps of host-pathogen interaction [6-13] (Fernandes et al., submitted to publication). After the adhesion, leptospires have to surmount tissue barriers in order to reach blood circulation and organs. Accordingly, we have reported the plasmin generation at the bacterial surface through the binding of the host PLG and the presence of an activator [14]. Moreover, our group has identified several leptospiral proteins as PLG - binding receptors [6,7,13,15]. Recently, we have described that plasmin generation on Leptospira decreased opsonization, a process that might help the bacteria to evade the immune system and increase survival [16]. 
The present work intends to report a novel adhesin of Leptospira encoded by LIC11087 gene, named Lsa30, we have identified among the genome sequences of Leptospira interrogans serovar Copenhageni. The rationale to select this CDS was based on its cellular location by bioinformatics analysis. The gene was cloned into the expression vector $\mathrm{pAE}$ and the recombinant protein was expressed in Escherichia coli heterologous host system. Purified Lsa30 protein was assayed for its binding capacity to ECM components. We show that Lsa30 mediates the binding to laminin and to plasma fibronectin. Moreover, Lsa30 interacts with PLG and generates plasmin in the presence of activator. Lsa30 also binds C4bp complement regulator and may contribute to the bacterial immune evasion. The recognition of this protein by serum samples of infected hamsters suggested its expression during infection. It is likely that this novel protein could be involved in several steps of leptospiral pathogenesis.

\section{Materials and methods}

\subsection{Leptospira strains and culture conditions}

Leptospires were cultured at $28{ }^{\circ} \mathrm{C}$ under aerobic conditions in liquid Ellinghausen-McCullough-Johnson-Harris medium (EMJH, Difco) with $10 \%$ rabbit serum, enriched with L-asparagine $(0.015 \%)$, sodium pyruvate $(0.001 \%)$, calcium chloride $(0.001 \%)$, magnesium chloride $(0.001 \%)$, peptone $(0.03 \%)$ and meat extract $(0.02 \%)($ all w/v). Low passage, virulent $L$. interrogans serovar Kennewicki strain Pomona Fromm was kept by iterative passages in Golden Syrian hamsters for maintenance. Recently weaned male Golden Syrian hamsters were intraperitonially infected with $500 \mu \mathrm{L}$ of approximately $1 \times 10^{4}$ virulent $L$. interrogans serovar Kennewicki strain Pomona Fromm. The animals were bled from the retro-orbital plexus after the appearance of symptoms, such as loss of weight and mobility (approximately 5 days post-infection).

\subsection{In silico sequence analysis}

Putative coding sequence (CDS) LIC11087 was identified on L. interrogans serovar Copenhageni genome sequences and selected based on cellular localization predicted by PSORT, http://psort.nibb. ac.jp [17] and CELLO, http://cello.life.nctu.edu.tw/ [18,19] web servers. For prediction of function and conserved structural domains within the amino acid sequences, SMART (http://smart. embl-heidelberg.de/smart/show_motifs.pl [20,21], Pfam http:// www.sanger.ac.uk/Software/Pfam/ [22] and LipoP http://www. cbs.dtu.dk/services/LipoP/ [23]) web servers were employed. Sequence analysis was performed by BLAST [24]. All sequences available in GeneBank were employed to study conservation and identity of LIC11087 using CLUSTAL 2.1 multiple sequence alignment at http://www.ebi.ac.uk/Tools/msa/clustalw2/ [25].

\subsection{Protein conservation among leptospiral strains}

Bacterial cultures of Leptospira spp. were harvested by centrifugation, washed three times with PBS containing $5 \mathrm{~mm} \mathrm{MgCl}_{2}$ and resuspended in PBS. The purified recombinant protein, or the protein extracts from leptospires, were loaded into 12\% SDS-PAGE, the proteins transferred to nitrocellulose membrane (Hybond ECL, GE Healthcare) in semidry equipment (GE Healthcare) and then analyzed by immunoblotting (see below).

\subsection{Gene cloning, protein expression and purification}

The gene was amplified from L. interrogans serovar Copenhageni strain Copenhageni, without signal peptide sequence tag. The PCR fragment was gel-purified and cloned into expression vector $\mathrm{pAE}$
(Illustra GFX PCR DNA and Gel band purification kit; GE Healthcare). This vector has a 6XHis tag allowing purification of recombinant proteins by metal-chelating chromatography [26]. The cloning process was checked by DNA sequencing on an ABI Prism 3730_L sequencer (Houston, TX, USA) with appropriate T7 promoter-specific primers (Forward 5': TAATACGACTCACTATAGGG and reverse 5': CAGCAGCCAACTCAGTTCCT). Culture of E. coli BL21 (DE3) transformed with pAE-LIC11087 was grown in Luria-Bertani (LB) broth with $100 \mu \mathrm{g}$ ampicillin $\mathrm{ml}^{-1}$ at $37^{\circ} \mathrm{C}$ until it reached O.D. $0.6-0.8$. The expression of recombinant protein was induced with IPTG $0.25 \mathrm{~mm}$ (isopropyl- $\beta$-D-thiogalactopyranoside) overnight. The cells were harvested by centrifugation and the bacterial pellets were resuspended in lysis buffer ( $10 \mathrm{~mm}$ Tris- $\mathrm{HCl}$ [pH 8.0], $200 \mathrm{~mm}$ $\mathrm{NaCl}, 200 \mathrm{mg} / \mathrm{ml}$ lysozyme, $2 \mathrm{~mm}$ phenylmethylsulfonyl fluoride [PMSF], and 1\% Triton X-100). The bacterial cell pellets were lysed on ice with the aid of a sonicator (Ultrasonic Processor; GE Healthcare). This protein was expressed in insoluble form, so it was solubilized in buffer containing $20 \mathrm{~mm}$ Tris- $\mathrm{HCl}$ (pH 12.0), $500 \mathrm{~mm}$ $\mathrm{NaCl}, 8 \mathrm{M}$ urea. Lsa30 was purified through $\mathrm{Ni}^{2+}$ charged beads in chelating fast-flow chromatographic column (GE Healthcare). The refolding and washing process was performed on-column by gradually removing urea $(6-0 \mathrm{M})$ and increasing concentrations of imidazole (5-60 mM), respectively. For removal of imidazole, the sample was dialyzed in buffer $20 \mathrm{~mm}$ Tris- $\mathrm{HCl}$ (pH 12.0), $500 \mathrm{~mm}$ $\mathrm{NaCl}$ and $0.1 \%$ glycine at $4{ }^{\circ} \mathrm{C}$. The expression of recombinant protein was confirmed with detection of His-tag by anti-his tag antibodies (dilution 1:2000).

\subsection{Circular dichroism (CD) spectroscopy}

Purified recombinant Lsa30 protein was dialyzed against sodium phosphate buffer ( $\mathrm{pH}$ 7.4). CD spectroscopy measurements were performed at $20{ }^{\circ} \mathrm{C}$ using a Jasco J-810 spectropolarimeter (Japan Spectroscopic, Tokyo) equipped with a Peltier unit for temperature control. Far-UV CD spectra were measured using a $1 \mathrm{~mm}$-pathlength cell at $0.5 \mathrm{~nm}$ intervals. The spectra were presented as an average of five scans recorded from 185 to $260 \mathrm{~nm}$. The residual molar ellipticity is expressed in degree $\times$ centimeter per decimole. Spectra data was submitted to K2D2 software, http://ogic.ca/ projects/k2d2, using the method that calculated the secondary structure content from the ellipticity experimental data [27].

\subsection{Analysis of immunogenic potential of Lsa30 in animals}

Female BALB/c mice (4-6 weeks old) were immunized subcutaneously twice with $10 \mu \mathrm{g}$ of rLIC11087 adsorbed in $10 \%$ ( vol $/ \mathrm{vol}$ ) of Alhydrogel [2\% $\mathrm{Al}(\mathrm{OH})_{3}$, Brenntag Biosector, Denmark]. Negative control mice were injected with PBS. Serum samples were collected before immunizations and 15 days after each immunization. The mice were bled from the retro orbital plexus and the sera of individual animals were analyzed by ELISA for determination of the antibody titers. All animal studies were approved by the Ethics Committee of the Instituto Butantan, São Paulo, SP, Brazil.

\subsection{Immunoblotting assay}

The purified Lsa30 was loaded into 12\% SDS-PAGE and transferred to nitrocellulose membranes (Hybond ECL; GE Healthcare) in semi-dry equipment. Membrane was blocked with 5\% non-fat dry milk and 2.5\% BSA in PBS containing 0.05\% Tween 20 (PBS-T) and then incubated with anti-His sequence tag monoclonal antibodies (1:2000) (GE Healthcare) or antibodies against Lsa30 (1:500) for $2 \mathrm{~h}$ at room temperature. After washing, the membrane was incubated with horseradish peroxidase (HRP)-conjugated anti-mouse $\operatorname{IgG}(1: 5000$; Sigma) in PBS-T for $1 \mathrm{~h}$. The protein's reactivity was 
developed by ECL reagent kit chemiluminescence substrate (GE Healthcare) with subsequent exposition to X-Ray film.

\subsection{Liquid-phase immunofluorescence (L-IFA)}

Localization of the protein encoded by LIC11087 on surface of L. interrogans was evaluated by Liquid-phase immunofluorescence (L-IFA) as described by Oliveira et al. [28]. The cells were grown and washed as described before. These cells were harvested at $10,000 \mathrm{rpm}$ for $15 \mathrm{~min}$ and nuclei were stained with $50 \mu \mathrm{g} / \mathrm{ml}$ propidium iodide, for $1 \mathrm{~h}$ at $37{ }^{\circ} \mathrm{C}$ in the dark. The cells were washed and incubated for $30 \mathrm{~min}$ with polyclonal mouse antiserum against rLIC11087 at a 1:50 dilution. After washing, the samples were incubated for 30 min with secondary antibody at a dilution of 1:50, goat anti-mouse IgG antibodies conjugated to fluorescein isothiocyanate (FITC; Sigma). Finally, the cells were washed twice and resuspended in PBS anti-fading solution (ProLong Gold; Molecular Probes). Immunofluorescence signal of labeled leptospires was detected using a confocal LSM 510 META microscope (Zeiss). The proteins LipL32 and DnaK were employed as outer membrane [29] and cytoplasmic [30,31] control, respectively.

\subsection{Binding of Lsa30 to ECM and to serum components}

The binding of Lsa30 to extracellular matrix and blood components was assessed by ELISA according to previously published protocol [8]. Plates of 96 wells were coated with $1 \mu \mathrm{g}$ of the components: laminin, collagen Type I, collagen Type IV, plasma fibronectin, cellular fibronectin, plasminogen, C4bp, complement, vitronectin, elastin, factor $\mathrm{H}$, fibrinogen and ECM in $100 \mu \mathrm{L}$ of PBS for $2 \mathrm{~h}$ at $37^{\circ} \mathrm{C}$. Gelatin and BSA were employed as negative controls. The wells were washed six times with PBS containing 0.05\% Tween 20 (PBS-T) and then blocked with $200 \mu \mathrm{L}$ of $10 \%$ (wt/vol) non-fat dry milk in PBS-T (overnight at $4{ }^{\circ} \mathrm{C}$ ). One microgram of Lsa30 was added to each well and incubated for $3 \mathrm{~h}$ at $37{ }^{\circ} \mathrm{C}$. The plates were washed three times and polyclonal antibody against Lsa30 was added in appropriate dilution for detection of protein binding. After the plates were washed, secondary antibody, HRP-conjugated goat anti-mouse IgG (Sigma), was added in dilution 1: 5000 and incubated for $1 \mathrm{~h}$ at $37^{\circ} \mathrm{C}$. The wells were washed three times, and o-phenylenediamine (OPD) ( $1 \mathrm{mg} / \mathrm{ml}$ ) in citrate phosphate buffer ( $\mathrm{pH} 5.0$ ) plus $1 \mu \mathrm{L} / \mathrm{ml} \mathrm{H}_{2} \mathrm{O}_{2}$ was added ( $100 \mu \mathrm{L}$ per well). The reaction proceeded for $10 \mathrm{~min}$ and was interrupted by the addition of $50 \mu \mathrm{L}$ of $4 \mathrm{~N} \mathrm{H}_{2} \mathrm{SO}_{4}$. The absorbance at $492 \mathrm{~nm}$ was determined in a microplate reader (TPreader; Thermo). Bindings were also confirmed by using HRPconjugated anti-his tag monoclonal antibodies, previously titrated against the recombinant protein and used in a dilution that generates an OD492nm value of approximately 1. For statistical analyses, the binding of recombinant protein to components was compared to its binding to negative control by Student's twotailed $t$ test.
A

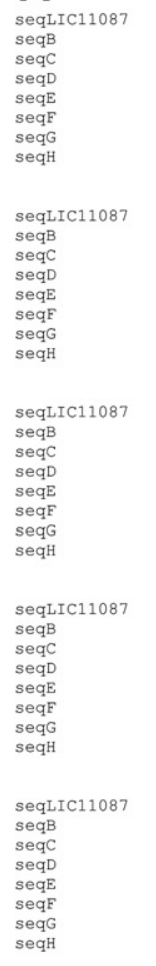

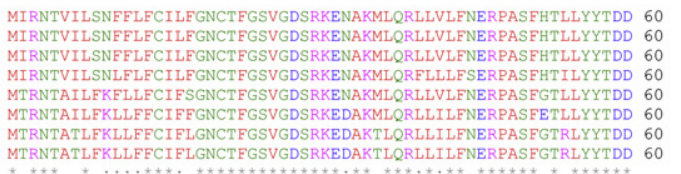
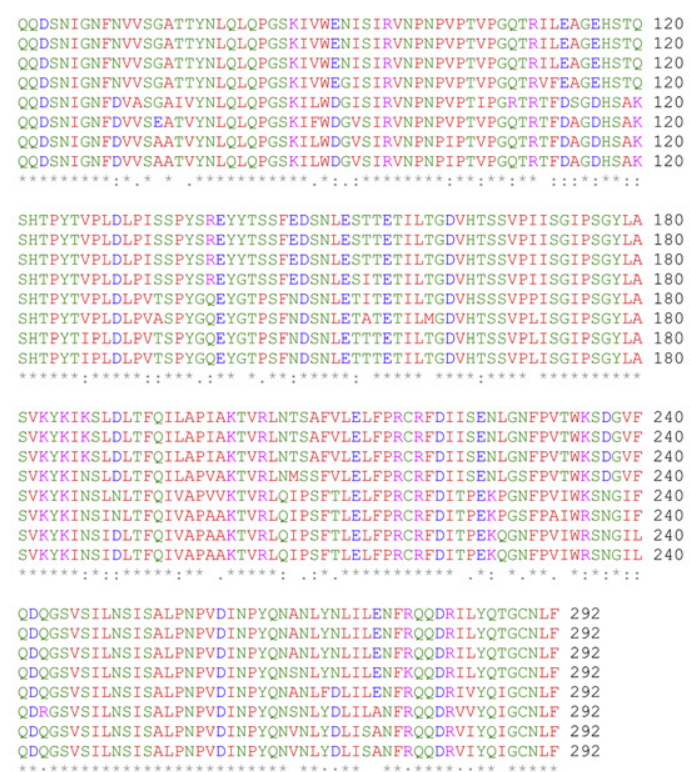

B

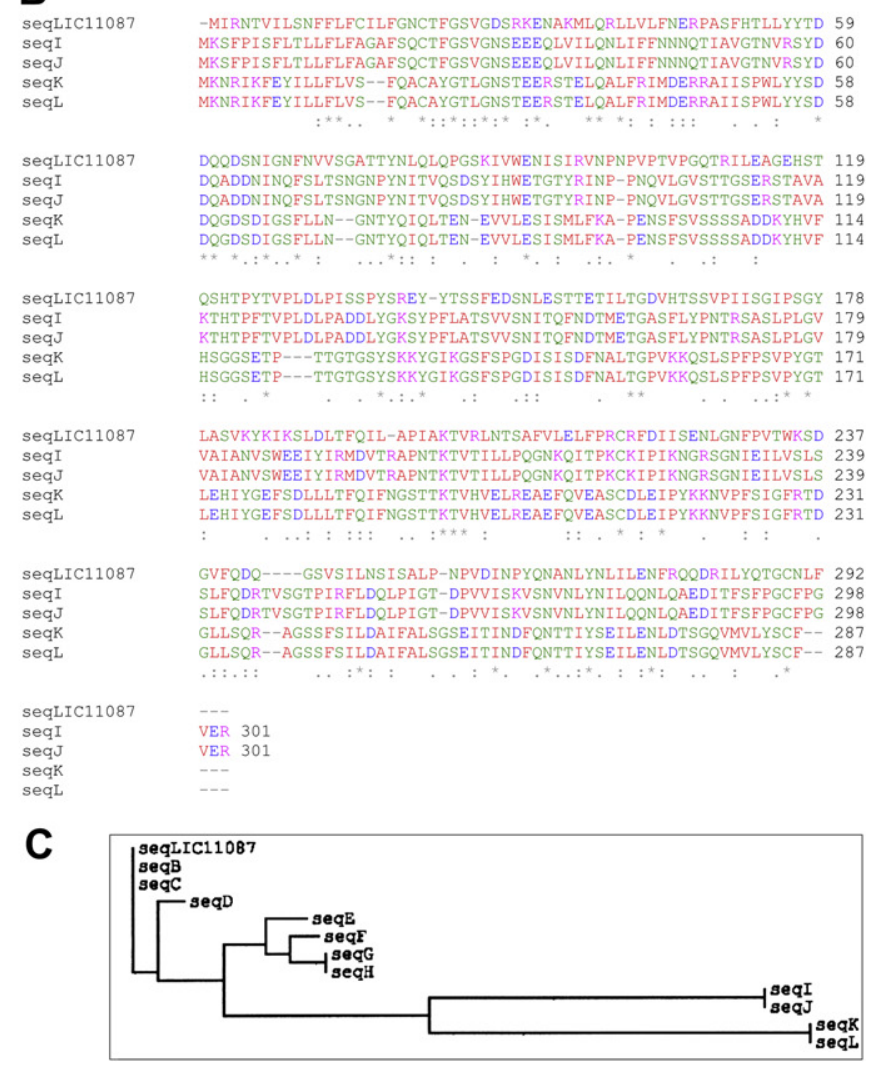

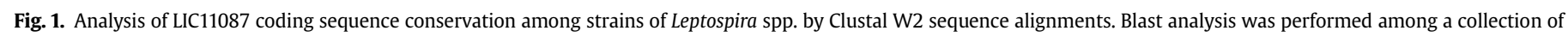

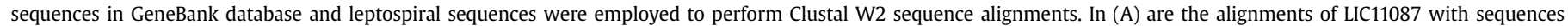

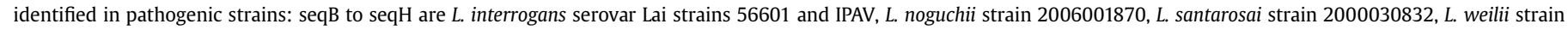

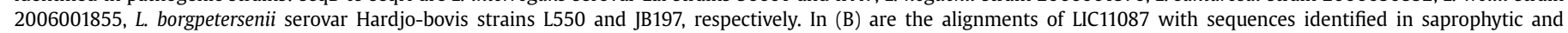

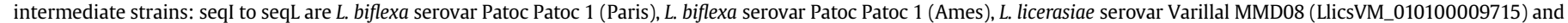

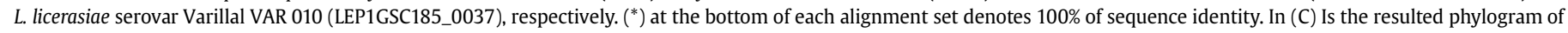

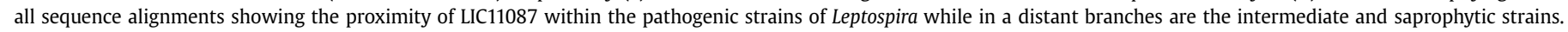




\subsection{Dose-response curves}

Microplate of 96 -wells were coated overnight in PBS at $4{ }^{\circ} \mathrm{C}$ with $100 \mu \mathrm{L}$ of $10 \mu \mathrm{g} / \mathrm{ml}$ PLG, plasma fibronectin, laminin or C4bp. Plates were then blocked and increasing concentrations of Lsa30 $(0-1.75 \mu \mathrm{m})$ were added $(100 \mu \mathrm{L} /$ well in PBS). The assessment of bound proteins was performed by incubation for $1 \mathrm{~h}$ at $37^{\circ} \mathrm{C}$ with the antiserum raised against each protein at the dilution of $1: 1,500$, followed by HRP-conjugated goat anti-mouse IgG (Sigma) (1:5000 in PBS). The reactions were detected with OPD as describe above. The ELISA data were used to calculate the dissociation constant $\left(K_{D}\right)$ according to the method described by Pathirana et al. [32] and Lin et al. [33], based on the equation: $A=A_{\max }$ [protein]/ $\left(K_{D}+\right.$ [protein]), where $A$ is the absorbance at a given protein concentration, $A_{\max }$ is the maximum absorbance for the ELISA plate reader (equilibrium), [protein] is the protein concentration and $K_{D}$ is the dissociation equilibrium constant for a given absorbance at a given protein concentration (ELISA data point).

\subsection{Plasmin enzymatic activity assay}

ELISA microplate was coated overnight with $10 \mu \mathrm{g} / \mathrm{ml}$ of Lsa30 in PBS at $4{ }^{\circ} \mathrm{C}$. Gelatin was employed as negative control. Plate was washed once with PBS-T and blocked for $2 \mathrm{~h}$ at $37^{\circ} \mathrm{C}$ with PBS with $10 \%$ (wt/vol) non-fat dry milk. The blocking solution was discarded and $100 \mu \mathrm{L} /$ well of $10 \mu \mathrm{g} / \mathrm{ml}$ human PLG was added, followed by incubation for $2 \mathrm{~h}$ at $37^{\circ} \mathrm{C}$. Wells were washed three times with PBS-T, and then $4 \mathrm{ng} /$ well of human uPA (Sigma-Aldrich) were added. Subsequently, $100 \mu \mathrm{L} /$ well of plasmin-specific substrate D-valyl-leucyl-lysine-pnitroanilide dihydrochloride (Sigma-Aldrich) were added at a final concentration of $0.4 \mathrm{~mm}$ in PBS. Plate was incubated overnight at $37^{\circ} \mathrm{C}$ and substrate degradation was measured by readings at $405 \mathrm{~nm}$.

\subsection{Reactivity of Lsa30 with serum samples from infected hamsters}

The recognition of the protein Lsa30 by antibodies of serum samples from 42 infected hamsters was investigated by ELISA. The
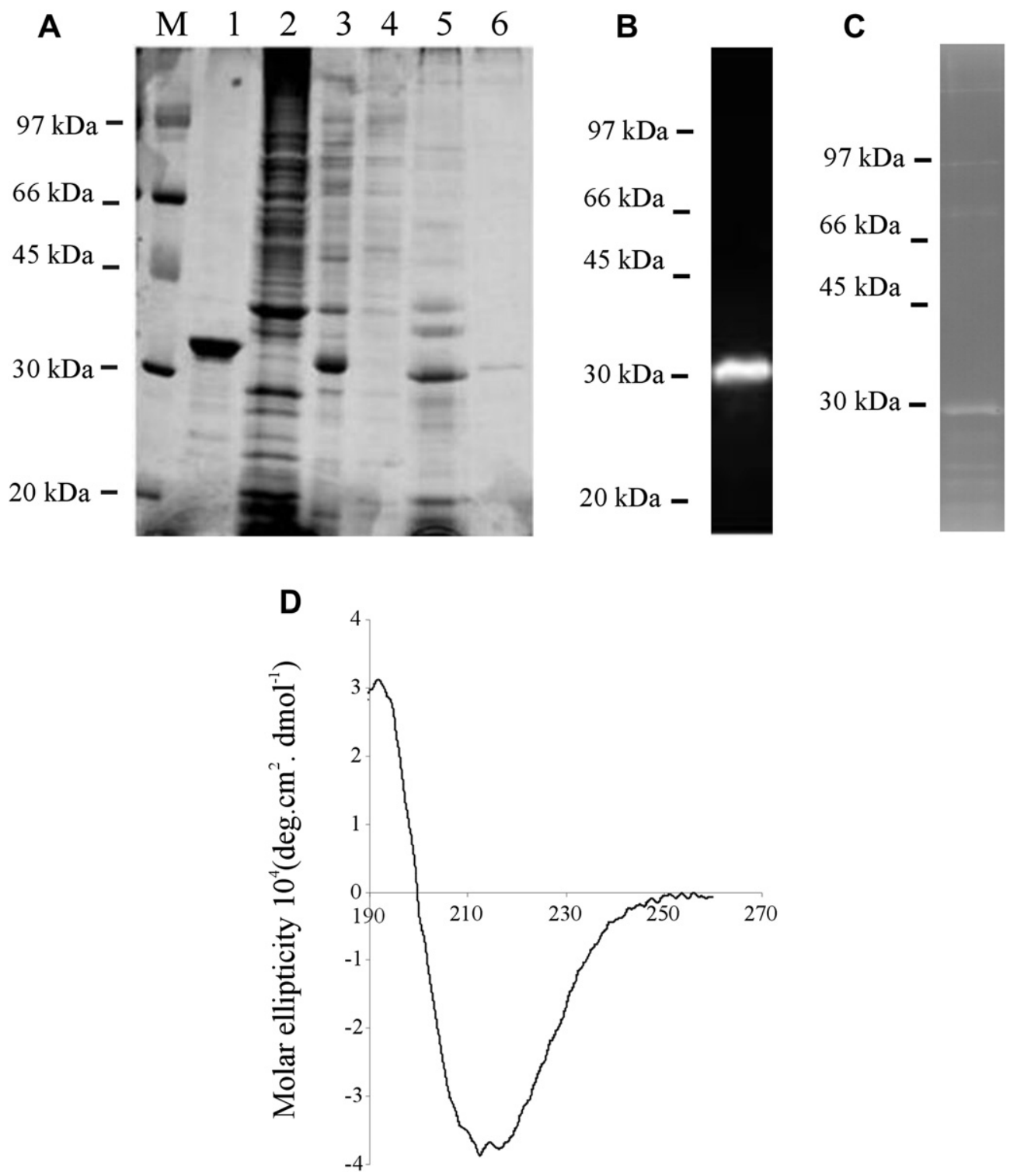

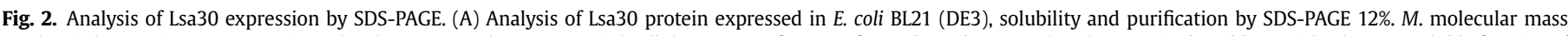

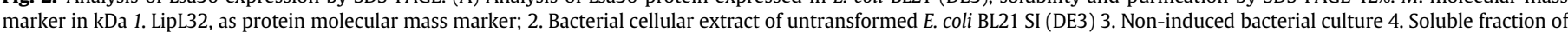

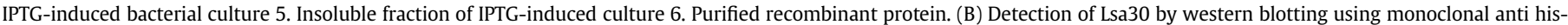

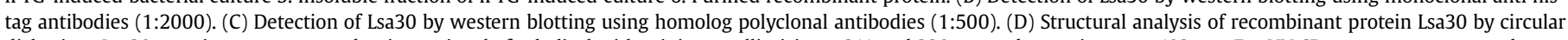

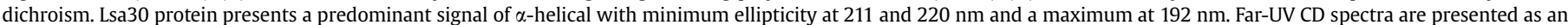
average of five scans recorded from 183 to $260 \mathrm{~nm}$. 
detection of hamsters IgG against Lsa30 was performed with rabbit anti-hamster (Sigma, USA) at dilution 1:100, followed by secondary antibody goat anti-rabbit IgG (Sigma, USA) at dilution 1: 2000. The cutoff values were calculated at three standard deviations above the mean OD492 $\mathrm{nm}$ of sera from 8 healthy animals.

\subsection{ECM and biological components}

Macromolecules, including the control protein fetuin, were purchased from Sigma Chemical Co. (St. Louis, Mo.). Laminin and collagen Type IV were derived from the basement membrane of Engelbreth-Holm-Swarm mouse sarcoma, cellular fibronectin was

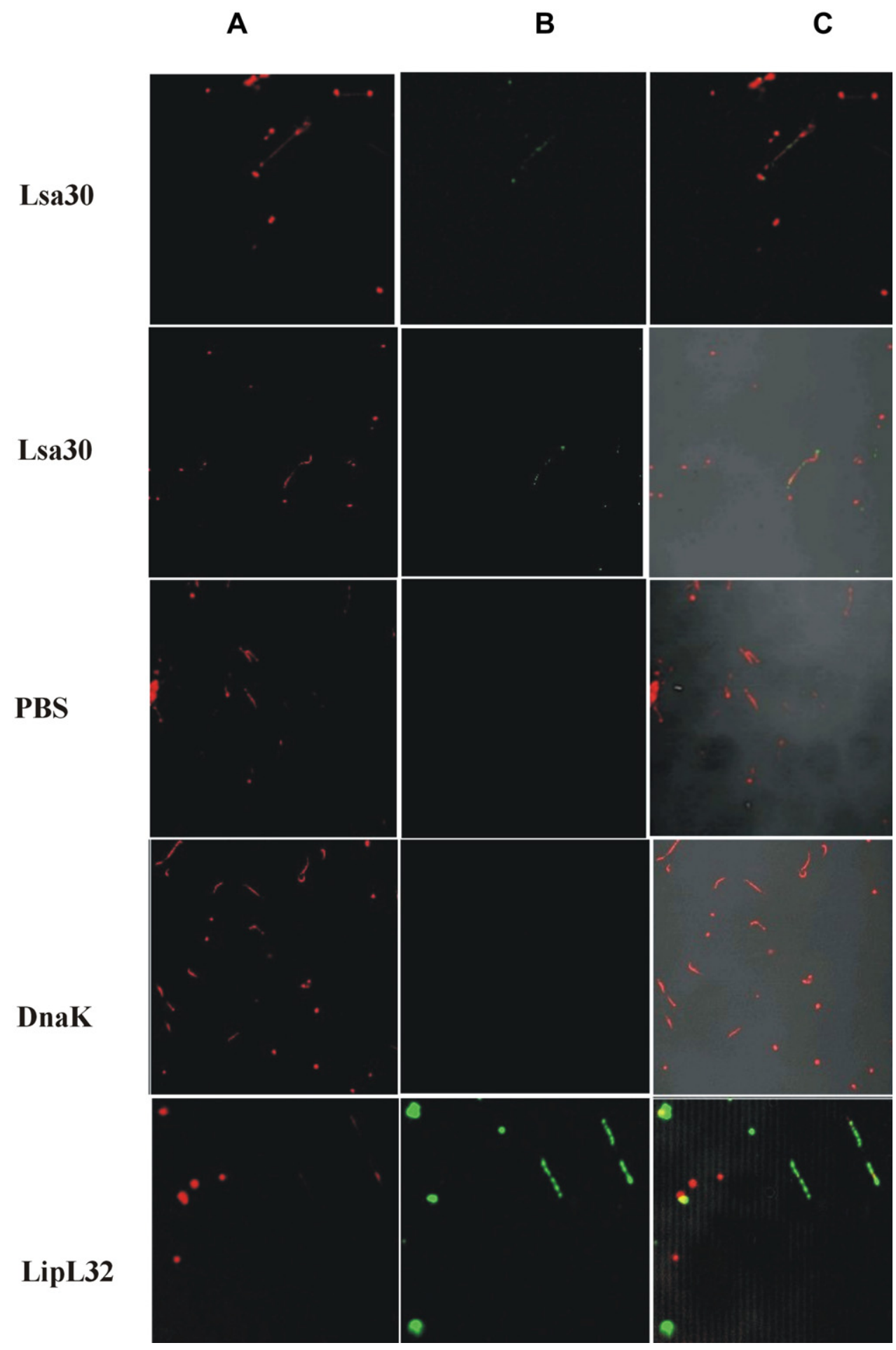

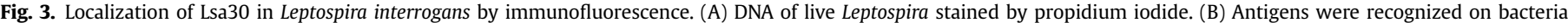

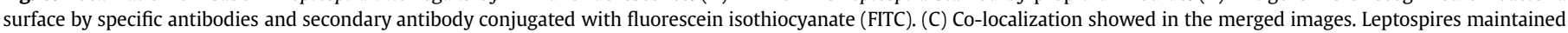
in PBS or treated with antibodies against the cytoplasmic DnaK or against the outer membrane protein LipL32 were employed as negative and positive control, respectively. 
derived from human foreskin fibroblasts, plasma fibronectin, human complement serum and fibrinogen were isolated from human plasma and collagen Type I was isolated from rat tail. Plasminogen native, purified from human plasma, was purchased from Merck. Human Factor $\mathrm{H}$ was from Calbiochem. C4bp was from Complement Technology, INC.

\section{Results}

\subsection{Bioinformatic analysis of the LIC11087 sequence}

The CDS LIC11087 was identified in the chromosome I of L. interrogans serovar Copenhageni genome sequences [34,35]. LIC11087 is predicted to be a membrane protein, based on the search for sequence motifs by the servers PSORT [17] and CELLO program $[18,19]$. No putative conserved domain within this sequence was detected according to SMART, PFAM and BLAST public web servers. BLAST analysis showed that CDS LIC11087 was identified in L. interrogans serovar Lai strains 56601 and IPAV (100\% identity), Leptospira borgpetersenii serovar Hardjo-bovis JB197 and L550 strains (77\% identity). LIC11087 CDS was also identified with high sequence similarity (79-98\%) in Leptospira noguchii strain 2006001870, Leptospira santarosai strain 2000030832 and Leptospira weilii strain 2006001855. Sequence with partial similarity (29-30\%) was identified in the saprophytic strains of Leptospira biflexa, Patoc 1 (Ames) and Patoc 1 (Paris), and in the strains of Leptospira licerasiae serovar Varillal MMD08 (LlicsVM_010100009715) and VAR 010 (LEP1GSC185_0037) that belongs to a group intermediate between pathogenic and saprophytic [36]. Multiple sequence alignment was performed with CLUSTAL 2.1 program comparing LIC11087 with the sequences from pathogenic strains (Fig. 1A) and the sequences from saprophytic and intermediated strains (Fig. 1B). The $\left(^{*}\right)$ at the bottom of sequences denotes high sequence identity. The phylogram of all sequences is depicted in Fig. 1C that clearly shows the similarity/proximity of LIC11087 with the sequence present in pathogenic strains while sequence present in saprophytic and intermediate strains have low similarity and are organized in a more distant branch.

\subsection{Cloning of the LIC11087 gene and expression of Lsa30 recombinant protein}

The amplified DNA fragment was cloned into the $E$. coli expression vector pAE. The pAE-LIC11087 positive clone was confirmed by DNA sequencing. The recombinant protein of $30 \mathrm{kDa}$ was expressed as a full-length protein in E. coli BL21 (DE3) and purified by $\mathrm{Ni}^{2+}$ charged chromatography. Fig. 2A shows the SDSPAGE analysis of protein expression and purification steps. The purified Lsa30 was recognized by monoclonal anti-his antibodies in immunoblotting (Fig. 2B) and by mice polyclonal antibodies against Lsa30 (Fig. 2C). The recombinant protein was expressed in insoluble form and was purified under denaturing conditions, followed by refolding process. The structural integrity of the purified protein was then assessed by CD spectroscopy, as depicted in Fig. 2D. The Lsa30 presents a predominant signal of $\alpha$-helical with minimum ellipticity at near 210 and $220 \mathrm{~nm}$ and the maximum at $192 \mathrm{~nm}$. The $\alpha$-helical predominance was also confirmed by analysis of the spectrum data by K2D2 software, which showed 63\% of alpha helix and $3.8 \%$ of $\beta$-sheets [27]. The results obtained showed that the recombinant protein is suitable for biological assays.

\subsection{Detection of the protein corresponding to the LIC11087 CDS in the Leptospira by confocal microscopy}

We used the liquid-phase immunofluorescence to demonstrate the expression of native LIC11087 protein in L. interrogans. The genomic DNA of living leptospires was labeled by propidium iodide staining (Fig. 3, column A) followed by incubation with the antiLsa30 in the presence of anti-mouse IgG antibodies conjugated to FITC (Fig. 3 column B). In control experiments, a green fluorescence could be observed with antisera that recognizes LipL32 antigen (Fig. 3), an outer membrane protein but not with DnaK, a cytoplasmic protein marker (Fig. 3). The localization of the proteingreen light on the leptospires was achieved by superimposing both fields and the results obtained are shown in Fig. 3, column C, for each protein, Lsa30, LipL32, DnaK. Lsa30 was weakly immunoreactive to intact spirochetes suggesting surface localization. No protein was detected with the control with PBS only.

\subsection{Reactivity of Lsa30 with sera from infected hamsters}

We have performed ELISA to analyze whether Lsa30 is recognized by antibodies present in experimentally infected hamsters. We have employed 42 serum samples of hamsters. Our data show that the recombinant protein was able to recognize IgG antibodies in 19 (45.2\%) of infected hamster's tested sera (Fig. 4), suggesting that this protein is expressed during animal infection.

\subsection{Protein conservation among leptospiral reference strains}

Protein expression and conservation among Leptospira strains was assessed with total protein extracts from the same strains of Leptospira we have employed for DNA conservation analysis. Cell extracts were gel fractionated and western blotting analysis was performed by probing the membranes with polyclonal serum from mice immunized with Lsa30. However, no protein band was detected with the leptospiral strains (data not shown).

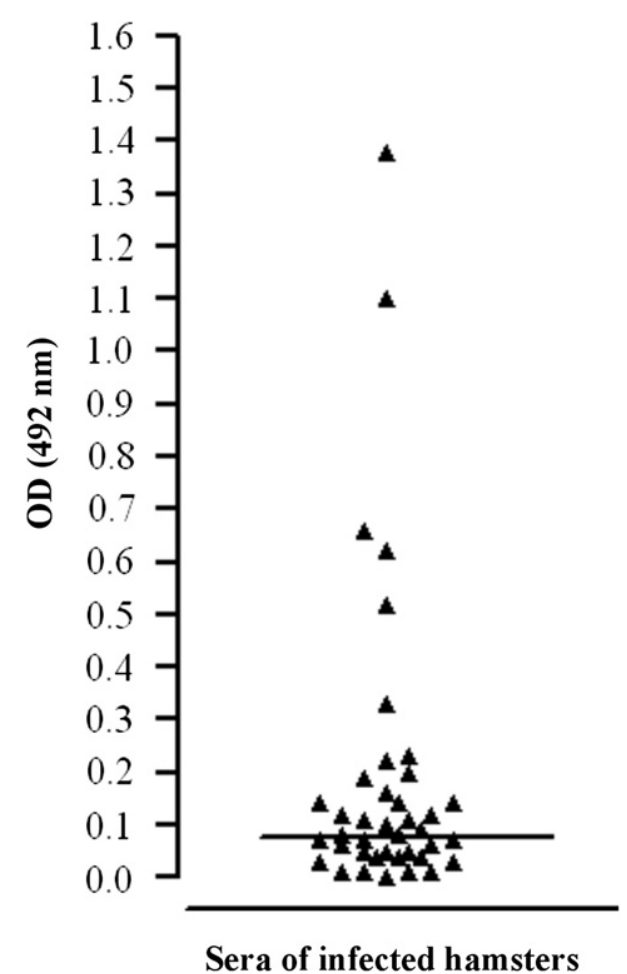

Fig. 4. Recognition of Lsa30 by IgG antibodies present in sera of infected hamsters. Positive sera (responders) were determined by ELISA with the recombinant protein and serum samples from experimentally infected hamsters. The reactivity was evaluated as total $\lg G$ antibodies. The cutoff values are defined as the mean plus 3 standard deviations obtained with sera from eight non-infected hamsters (horizontal bars). 


\subsection{Adhesion of Lsa30 to ECM components}

Laminin, collagen Type I, collagen Type IV, cellular fibronectin, plasma fibronectin, vitronectin, elastin and the control proteins, BSA and gelatin, were immobilized on microdilution wells and recombinant protein attachment was assessed by ELISA, using anti-Lsa30 polyclonal antiserum to probe the reactivity. Lsa30 protein exhibited efficient adhesiveness to laminin $(P<0.001)$ and plasma fibronectin $(P<0.01)$ compared to the control protein gelatin (Fig. 5A). The binding was also observed when monoclonal anti-his antibodies were used to probe the bound protein (Fig. 5B). No reaction was observed in the absence of Lsa30 when either anti-Lsa30 or anti-his were employed. No statistically significant adhesiveness was observed with Lsa30 when wells were coated with collagen Type I and IV and cellular fibronectin, vitronectin, elastin or the control proteins. The interaction between Lsa30 with laminin and plasma fibronectin was also assessed on a quantitative basis, as shown in Fig. 5C and D. A dose-dependent and saturable binding were observed when increasing concentrations of the recombinant protein $(0-1.75 \mu \mathrm{M})$ were allowed to adhere to a fixed concentration of laminin or plasma fibronectin ( $1 \mu \mathrm{g}$ each). In the case of laminin, saturation level was reached at a protein concentration of $1.5 \mu \mathrm{M}$ (Fig. 5C) and the calculated dissociation equilibrium constant $\left(K_{D}\right)$ for Lsa30 with laminin is $292 \pm 24 \mathrm{~nm}$. Saturation level for plasma fibronectin was also reached at $1.5 \mu \mathrm{m}$ of Lsa30 (Fig. 5D) with a calculated $K_{D}$ of $157 \pm 35$ nм.

\subsection{Interaction of Lsa30 to serum components}

The ability of the protein Lsa30 to interact to serum components, human plasminogen, complement, factor $\mathrm{H}, \mathrm{C} 4 \mathrm{bp}$ in vitro was evaluated. The components and the control protein gelatin were individually immobilized onto 96-wells plates followed by incubation with Lsa30. The results obtained using polyclonal antibodies against the recombinant protein to probe the reactions showed that the protein interacts with C4bp and PLG (Fig. 6A). No reaction was observed with factor $\mathrm{H}$, complement and the control proteins (Fig. 6A). Similar data were confirmed when binding was probed using monoclonal anti-his tag antibodies (Fig. 6B). These data were further confirmed when the reaction between Lsa30 with PLG and Lsa30 with C4bp were assessed on a quantitative basis as depicted in Fig. 6C and D, respectively. Dose-dependence was observed when increasing concentrations $(0-1.75 \mu \mathrm{M})$ of the recombinant protein Lsa30 were allowed to adhere to a fixed amount $(1 \mu \mathrm{g})$ of PLG or C4bp. In both cases, however, saturation
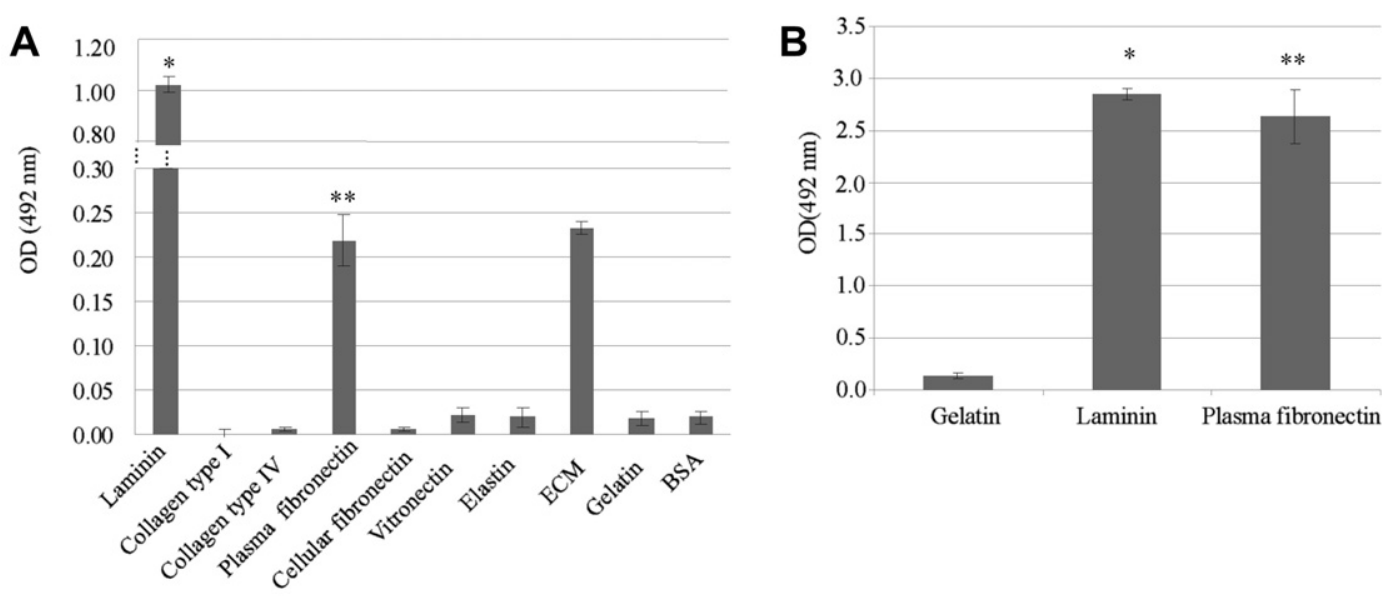

\section{C}

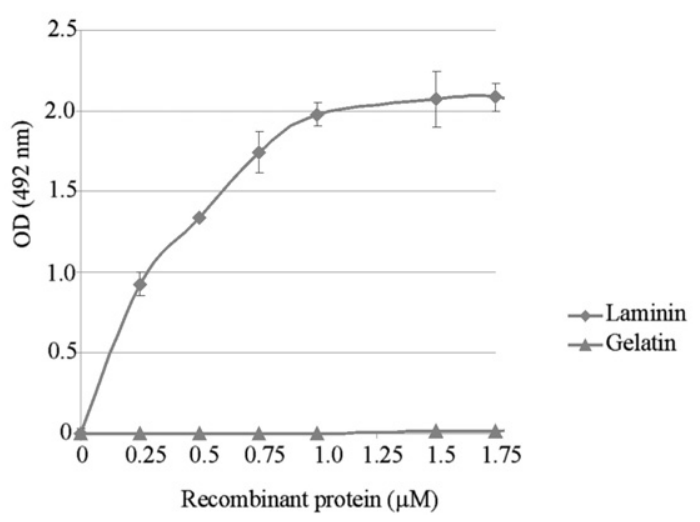

D

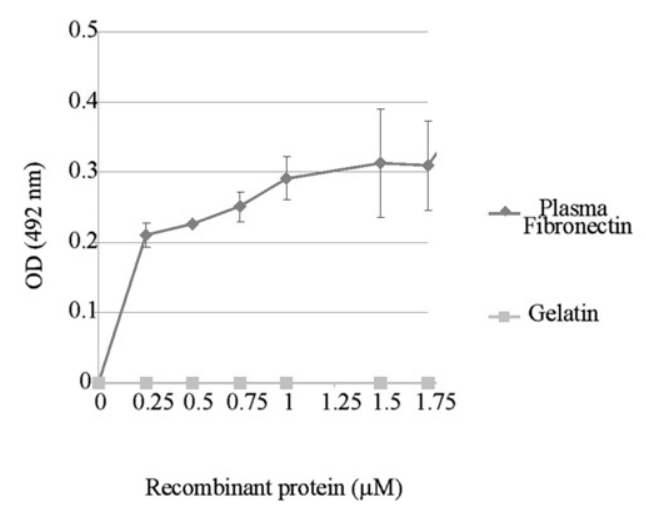

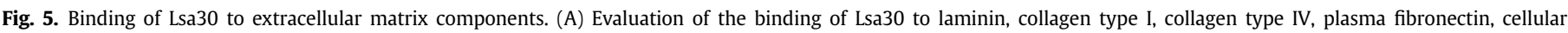

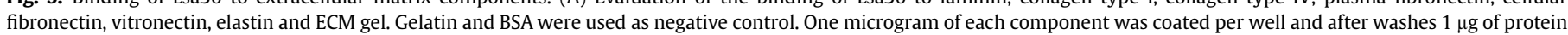

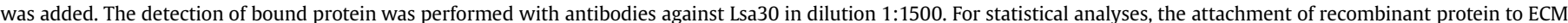

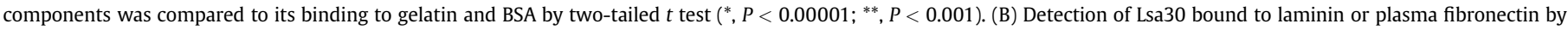

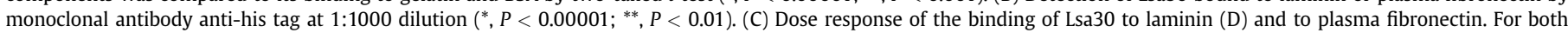

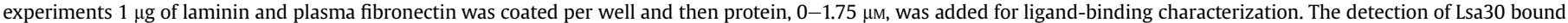

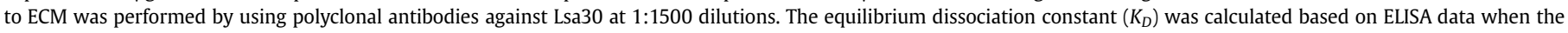
equilibrium concentration was reached. All experiments data represent the mean absorbance values standard deviation of three replicates for each experimental group. 

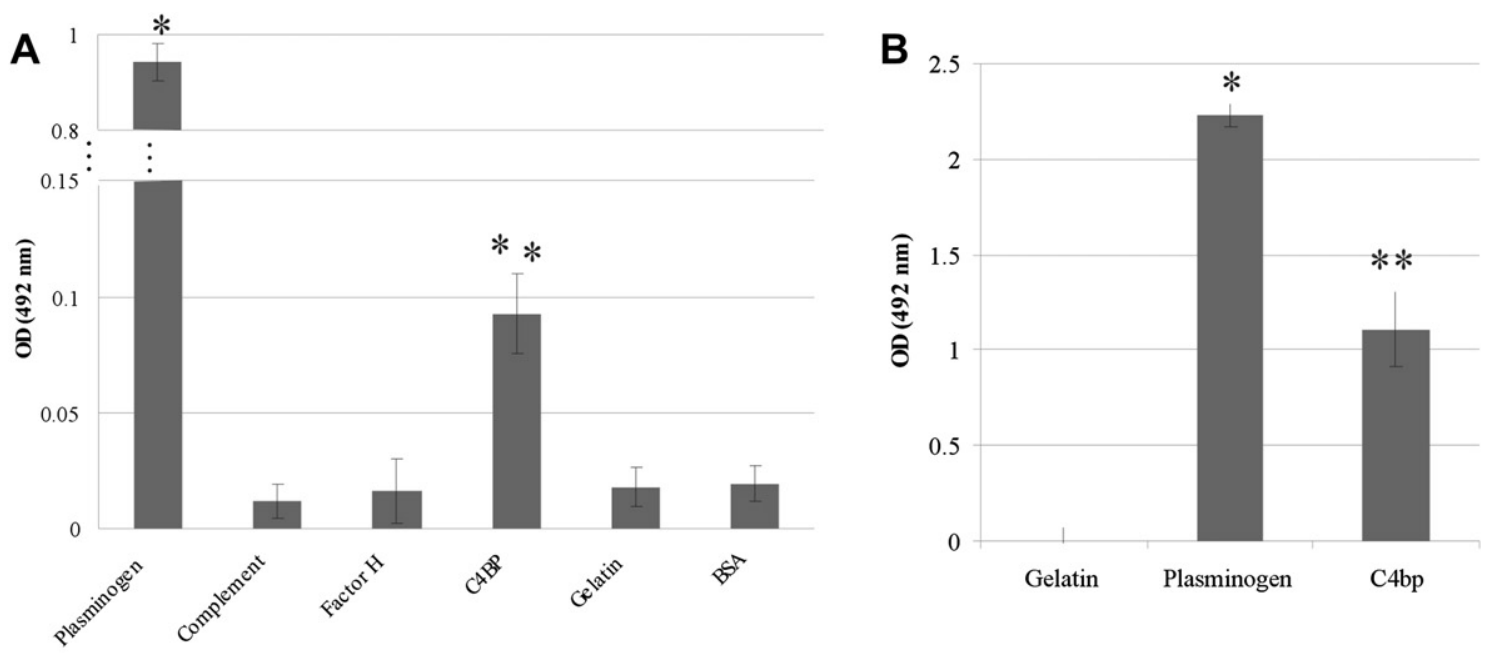

C

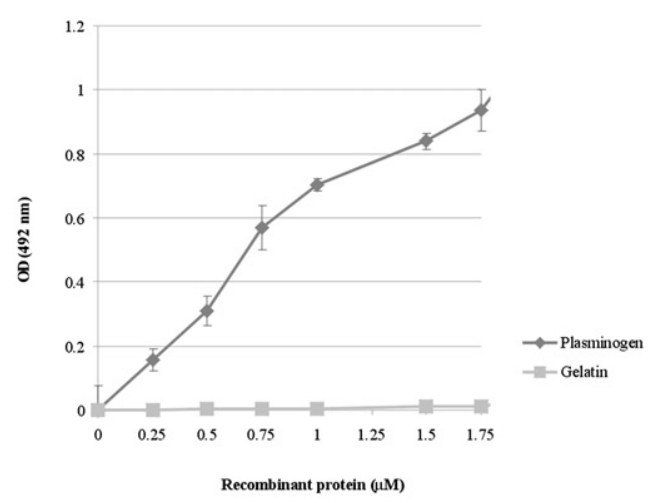

D

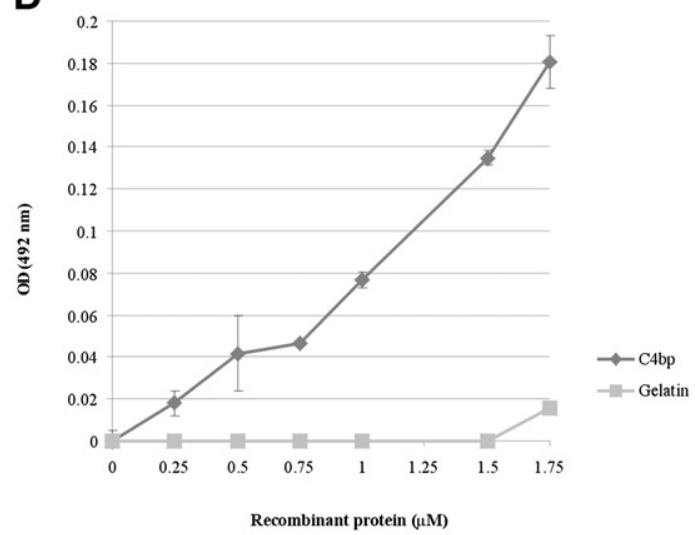

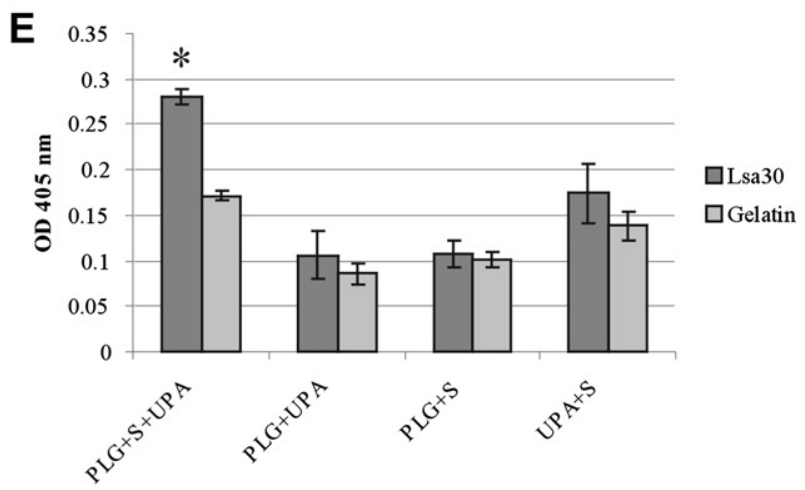

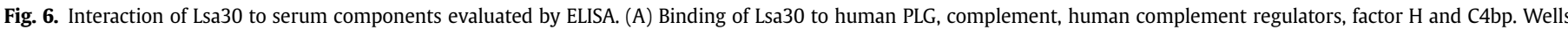

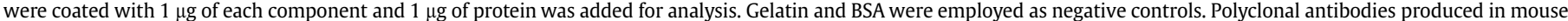

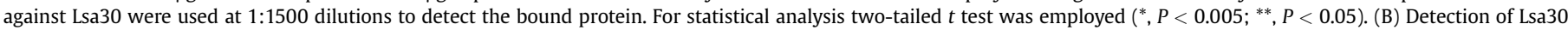

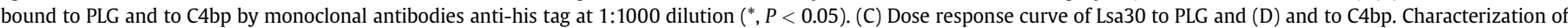

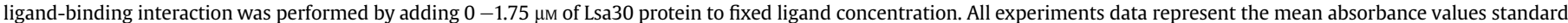

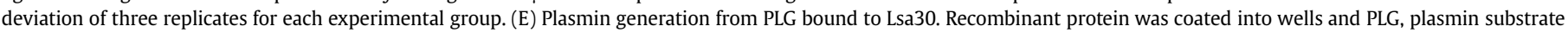

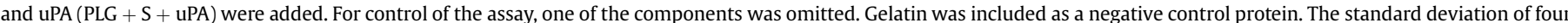

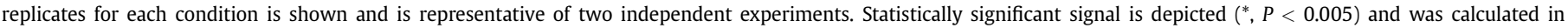
comparison to the negative control (gelatin).

level was not reached within the protein concentration range used, suggesting low affinity of Lsa30 with the two ligands.

Leptospira and proteins within their surface can bind PLG and acquire proteolytic activity in the presence of an activator, as we have previously shown [7,13-15]. Therefore, we investigated whether Lsa30 bound to PLG could also generate the enzymatically active plasmin. Microplates were coated with the recombinant protein, blocked, and then incubated with PLG. Unbound PLG was washed away and the urokinase-type PLG activator (uPA) was added together with a plasmin-specific chromogenic substrate. The reaction was carried out overnight and the plasmin activity was evaluated by measuring the cleavage of the substrate (absorbance 
at $405 \mathrm{~nm}$ ). The results show that the PLG captured by the Lsa30 protein could be converted into plasmin, as demonstrated indirectly by specific proteolytic activity (Fig. $6 \mathrm{E}$ ). The negative control gelatin did not show any proteolytic activity, similar to the controls lacking one of the components, PLG, uPA or the chromogenic substrate.

\section{Discussion}

Since we have sequenced the whole genome of $L$. interrogans serovar Copenhageni [34,35] our group is committed to identify antigen candidates that would help fight leptospirosis. Bioinformatics have predicted 184 coding sequences that appeared to be exported to the leptospiral surface, and therefore with the potential to participate in the host-pathogen interactions [34]. The majority of these proteins are annotated as hypothetical with no assigned function. By data mining this pool of sequences, we have identified several novel leptospiral adhesins [7-13] and proteins that are capable to promote upregulation of cellular adhesion molecules (CAMs) in endothelial cells [37,38].

After cell adhesion, pathogens must penetrate tissues in order to reach blood circulation and target organs. Plasmin proteolytic activity can help the invasive bacteria to overcome these barriers. We have reported that similar to other pathogens, leptospires can generate plasmin on their surface by binding host PLG in the presence of activators [14]. This proteolytic activity can degrade fibronectin and laminin thus helping the leptospiral invasion [14] (Vieira et al., unpublished results).

We report in this work a novel L. interrogans protein encoded by the gene LIC11087, genome annotated as hypothetical. Due to the high degree of antigenic variation among leptospires, we examined the gene/protein conservation among a collection of sequences in GeneBank database. The LIC11087 coding sequence seems to be broadly spread and with high percentage of identity among pathogenic strains of Leptospira, while low homology was detected in leptospiral intermediate and saprophytic strains. However, we could not detect the presence of the protein encoded by LIC11087 in all these leptospiral extracts when probed with antibodies raised against the recombinant protein Lsa30. One possible explanation is the fact that this protein although identified by proteomics did not fall in protein abundance scale to have its number of copies calculated [39], indicating very low level of protein expression.

The LIC11087 CDS was expressed in E. coli as a $30 \mathrm{kDa}$ full-length recombinant protein, named Lsa30. This protein was expressed in its insoluble from $E$. coli BL21 (DE3) expression host, purified under denaturing conditions followed by protein refolding through extensively dialysis. The secondary structure of the recombinant protein after the purification/refolding processes has been one of our concerns because some denatured proteins may lose their immunogenicity and immunoprotection activities [40]. CD spectroscopy showed a predominant signal of $\alpha$-helical secondary structure content that makes the Lsa30 suitable for further studies.

The Lsa30 is probably a new surface protein of Leptospira, as shown by liquid-phase immunofluorescence assays with living organisms and the reactivity with antibodies present in serum samples of experimentally infected hamsters. The Lsa30 protein has extracellular matrix-binding activity and it is likely that it may have a role in the attachment to host. This protein exhibits a binding profile similar to the previously reported Lsa66 [7] and Lsa20 [13] that are laminin and plasma fibronectin interacting proteins, but distinct of other adhesins like Lsa24 and Lsa27 that are lamininbinding proteins [8]. Several adhesins have been reported to bind to different ECM macromolecules [41]. Indeed, the attachment of Leptospira to several ECM macromolecules has been previously shown [8]. The binding affinity dissociation constants estimated for
Lsa30 to laminin $\left(K_{D}=292 \pm 24 \mathrm{~nm}\right)$ showed similar value of that reported for OmpL37 [42], Lsa66 [7], Lsa33 and Lsa25 [6]. In the case of plasma fibronectin, the calculated $K_{D}(157 \pm 35 \mathrm{~nm})$ is in the same order of magnitude when compared to the $K_{D}$ values obtained with LenB [41], LigA [43], LipL32 [44,45], OmpL37 [42] and Lsa66 [7] and the same ECM component. Thus, it is possible that Lsa30 mediates the leptospiral adhesion process.

The spirochetes Borrelia spp. and Treponema denticola were shown to have PLG activation system with generation of plasmin on their surface with possible implications on the pathogenesis [46]. We have reported this PLG/PLA acquired proteolytic activity for the first time with Leptospira spp. [14]. Plasmin is a versatile serine protease with the ability to digest a broad spectrum of substrates, such as fibrin clots, connective tissue and components of extracellular matrices [47,48]. Verma and colleagues [49] have reported that LenA is a bacterial cell surface receptor for human PLG and that LenA-bound PLG could be converted to plasmin. Thus Lsa30, similarly to LenA [49] and other leptospiral proteins described $[6,7,13,15]$, is a human PLG-binding receptor that generates plasmin in the presence of an activator. Thus, it is likely that Lsa30 may participate in the leptospiral invasion and dissemination.

C4b-binding protein (C4bp) controls the complement classical pathway by interfering with the formation and regeneration of $\mathrm{C} 3$ convertase and acting as a cofactor to the serine proteinase factor I in the proteolytic inactivation of $\mathrm{C} 4 \mathrm{~b}[50,51]$. Leptospiral binding proteins to $\mathrm{C} 4 \mathrm{bp}$, factor $\mathrm{H}$ and factor $\mathrm{H}$-like have been identified [41,52-54]. The interaction of C4bp and of factor $\mathrm{H}$ with other pathogens has been described, including the spirochetes Borrelia spp. [55,56]. Recently, we have identified two novel leptospiral adhesins, Lsa33 and Lsa25 that have the capacity of binding the human complement regulator C4bp [6]. Lsa30 also has the ability to interact with this complement regulator C4bp and may help the leptospires to evade the immune system.

\section{Conclusions}

We have identified among the sequences of $L$. interrogans serovar Copenhageni the LIC11087 CDS, genome annotated as hypothetical protein of unknown function. We have characterized this protein, named Lsa30, as a novel leptospiral adhesin. The Lsa30 protein acts as PLG-receptors and could confer proteolytic activity to the bacteria through the generation of plasmin. Moreover, this protein interferes with complement cascade by interacting with the regulator C4bp. Thus, Lsa30 is a multifunctional protein that may play a role on the Leptospira-host interactions.

\section{References}

[1] Levett PN. Leptospirosis. Clinical Microbiology Reviews 2001;14:296-326

[2] Leptospirosis worldwide, 1999. Releve epidemiologique hebdomadaire/ Section d'hygiene du Secretariat de la Societe des Nations = Weekly epidemiological record/Health Section of the Secretariat of the League of Nations. 1999; 74:237-42.

[3] Faine S, Adler B, Bolin C, Perolat P. Leptospira and leptospirosis. Melbourne, Australia: MediSci; 1999.

[4] Yan Y, Chen Y, Liou W, Ding J, Chen J, Zhang J, et al. An evaluation of the serological and epidemiological effects of the outer envelope vaccine to leptospira. Journal of the Chinese Medical Association: JCMA 2003;66:224-30.

[5] Martinez R, Perez A, Quinones Mdel C, Cruz R, Alvarez A, Armesto M, et al. [Efficacy and safety of a vaccine against human leptospirosis in Cuba]. Revista Panamericana De Salud Publica $=$ Pan American Journal of Public Health 2004; 15:249-55.

[6] Domingos RF, Vieira ML, Romero EC, Goncales AP, Morais ZM, Vasconcellos SA et al. Features of two proteins of leptospira interrogans with potential role in host-pathogen interactions. BMC Microbiology 2012;12:50.

[7] Oliveira R, de Morais ZM, Goncales AP, Romero EC, Vasconcellos SA Nascimento AL. Characterization of novel OmpA-like protein of leptospira interrogans that binds extracellular matrix molecules and plasminogen. PloS One 2011;6:e21962. 
[8] Barbosa AS, Abreu PA, Neves FO, Atzingen MV, Watanabe MM, Vieira ML, et al. A newly identified leptospiral adhesin mediates attachment to laminin. Infection and Immunity 2006;74:6356-64.

[9] Atzingen MV, Barbosa AS, De Brito T, Vasconcellos SA, de Morais ZM, Lima DM, et al. Lsa21, a novel leptospiral protein binding adhesive matrix molecules and present during human infection. BMC Microbiology 2008;8:70.

[10] Atzingen MV, Gomez RM, Schattner M, Pretre G, Goncales AP, de Morais ZM, et al. Lp95, a novel leptospiral protein that binds extracellular matrix components and activates e-selectin on endothelial cells. The Journal of Infection 2009;59:264-76.

[11] Longhi MT, Oliveira TR, Romero EC, Goncales AP, de Morais ZM, Vasconcellos SA, et al. A newly identified protein of leptospira interrogans mediates binding to laminin. Journal of Medical Microbiology 2009;58: 1275-82.

[12] Vieira ML, de Morais ZM, Goncales AP, Romero EC, Vasconcellos SA, Nascimento AL. Lsa63, a newly identified surface protein of leptospira interrogans binds laminin and collagen IV. The Journal of Infection 2010;60:52-64

[13] Mendes RS, Atzingen MV, Morais ZM, Gonçales AP, Serrano SM, Asega AS, et al. The novel leptospiral surface adhesin Lsa20 binds laminin and human plasminogen and is probably expressed during infection. Infection and Immunity 2011;79:4657-67.

[14] Vieira ML, Vasconcellos SA, Goncales AP, de Morais ZM, Nascimento AL. Plasminogen acquisition and activation at the surface of leptospira species lead to fibronectin degradation. Infection and Immunity 2009;77:4092-101.

[15] Vieira ML, Atzingen MV, Oliveira TR, Oliveira R, Andrade DM, Vasconcellos SA, et al. In vitro identification of novel plasminogen-binding receptors of the pathogen Leptospira interrogans. PloS One 2010;5:e11259.

[16] Vieira ML, de Morais ZM, Vasconcellos SA, Romero EC, Nascimento AL. In vitro evidence for immune evasion activity by human plasmin associated to pathogenic leptospira interrogans. Microbial Pathogenesis 2011:51:360-5.

[17] Nakai K, Kanehisa M. Expert system for predicting protein localization sites in gram-negative bacteria. Proteins 1991;11:95-110.

[18] Yu CS, Lin CJ, Hwang JK. Predicting subcellular localization of proteins for Gramnegative bacteria by support vector machines based on n-peptide compositions. Protein Science: a Publication of the Protein Society 2004;13:1402-6.

[19] Yu CS, Chen YC, Lu CH, Hwang JK. Prediction of protein subcellular localization. Proteins 2006;64:643-51.

[20] Schultz J, Milpetz F, Bork P, Ponting CP. SMART, a simple modular architecture research tool: identification of signaling domains. Proceedings of the National Academy of Sciences of the United States of America 1998;95:5857-64.

[21] Letunic I, Copley RR, Pils B, Pinkert S, Schultz J, Bork P. SMART 5: domains in the context of genomes and networks. Nucleic Acids Research 2006;34: D257-60.

[22] Finn RD, Mistry J, Schuster-Bockler B, Griffiths-Jones S, Hollich V, Lassmann T, et al. Pfam: clans, web tools and services. Nucleic Acids Research 2006;34: D247-51.

[23] Juncker AS, Willenbrock H, Von Heijne G, Brunak S, Nielsen H, Krogh A. Prediction of lipoprotein signal peptides in Gram-negative bacteria. Protein Science 2003;12:1652-62.

[24] Altschul SF, Madden TL, Schaffer AA, Zhang J, Zhang Z, Miller W, et al. Gapped BLAST and PSI-BLAST: a new generation of protein database search programs. Nucleic Acids Research 1997;25:3389-402.

[25] Larkin MA, Blackshields G, Brown NP, Chenna R, McGettigan PA, McWilliam H, et al. Clustal W and Clustal X version 2.0. Bioinformatics 2007;23:2947-8.

[26] Ramos CR, Abreu PA, Nascimento AL, Ho PL. A high-copy T7 Escherichia coli expression vector for the production of recombinant proteins with a minimal $\mathrm{N}$-terminal His-tagged fusion peptide [et al]. Brazilian Journal of Medical and Biological Research = Revista Brasileira De Pesquisas Medicas E Biologicas/ Sociedade Brasileira De Biofisica 2004;37:1103-9.

[27] Perez-Iratxeta C, Andrade-Navarro MA. K2D2: estimation of protein secondary structure from circular dichroism spectra. BMC Structural Biology 2008;8:25.

[28] Oliveira TR, Longhi MT, de Morais ZM, Romero EC, Blanco RM, Kirchgatter K, et al. Evaluation of leptospiral recombinant antigens MPL17 and MPL21 for serological diagnosis of leptospirosis by enzyme-linked immunosorbent assays. Clinical and Vaccine Immunology 2008;15:1715-22.

[29] Haake DA, Chao G, Zuerner RL, Barnett JK, Barnett D, Mazel M, et al. The leptospiral major outer membrane protein LipL32 is a lipoprotein expressed during mammalian infection. Infection and Immunity 2000;68:2276-85.

[30] Stamm LV, Gherardini FC, Parrish EA, Moomaw CR. Heat shock response of spirochetes. Infection and Immunity 1991;59:1572-5.

[31] Guerreiro H, Croda J, Flannery B, Mazel M, Matsunaga J, Galvao Reis M, et al. Leptospiral proteins recognized during the humoral immune response to leptospirosis in humans. Infection and Immunity 2001;69:4958-68.

[32] Pathirana RD, O’Brien-Simpson NM, Veith PD, Riley PF, Reynolds EC. Characterization of proteinase-adhesin complexes of porphyromonas gingivalis. Microbiology (Reading, England) 2006;152:2381-94.

[33] Lin YP, Lee DW, McDonough SP, Nicholson LK, Sharma Y, Chang YF. Repeated domains of leptospira immunoglobulin-like proteins interact with elastin and tropoelastin. The Journal of Biological Chemistry 2009;284:19380-91.
[34] Nascimento AL, Ko AI, Martins EA, Monteiro-Vitorello CB, Ho PL, Haake DA, et al. Comparative genomics of two leptospira interrogans serovars reveals novel insights into physiology and pathogenesis. Journal of Bacteriology 2004; 186:2164-72.

[35] Nascimento AL, Verjovski-Almeida S, Van Sluys MA, Monteiro-Vitorello CB Camargo LE, Digiampietri LA, et al. Genome features of leptospira interrogans serovar Copenhageni [et al]. Brazilian Journal of Medical and Biological Research = Revista Brasileira De Pesquisas Medicas E Biologicas/Sociedade Brasileira De Biofisica 2004;37:459-77.

[36] Matthias MA, Ricaldi JN, Cespedes M, Diaz MM, Galloway RL, Saito M, et al. Human leptospirosis caused by a new, antigenically unique leptospira associated with a Rattus species reservoir in the Peruvian Amazon. PLoS Neglected Tropical Diseases 2008;2:e213.

[37] Gomez RM, Vieira ML, Schattner M, Malaver E, Watanabe MM, Barbosa AS et al. Putative outer membrane proteins of leptospira interrogans stimulate human umbilical vein endothelial cells (HUVECS) and express during infection. Microbial Pathogenesis 2008;45:315-22.

[38] Vieira ML, D'Atri LP, Schattner M, Habarta AM, Barbosa AS, de Morais ZM, et al. A novel leptospiral protein increases ICAM-1 and E-selectin expression in human umbilical vein endothelial cells. FEMS Microbiology Letters 2007;276: $172-80$.

[39] Malmstrom J, Beck M, Schmidt A, Lange V, Deutsch EW, Aebersold R. Proteome-wide cellular protein concentrations of the human pathogen Leptospira interrogans. Nature 2009;460:762-5.

[40] Pertinhez TA, Sforca ML, Alves AC, Ramos CR, Ho PL, Tendler M, et al. 1H, 15N and $13 \mathrm{C}$ resonance assignments of the apo Sm14-M20(C62V) protein a mutant of Schistosoma mansoni Sm14. Journal of Biomolecular NMR 2004; 29:553-4.

[41] Stevenson B, Choy HA, Pinne M, Rotondi ML, Miller MC, Demoll E, et al Leptospira interrogans endostatin-like outer membrane proteins bind host fibronectin, laminin and regulators of complement. PloS One 2007;2:e1188.

[42] Pinne M, Choy HA, Haake DA. The OmpL37 surface-exposed protein is expressed by pathogenic Leptospira during infection and binds skin and vascular elastin. PLoS Neglected Tropical Diseases 2010;4:e815.

[43] Choy HA, Kelley MM, Chen TL, Moller AK, Matsunaga J, Haake DA. Physiological osmotic induction of leptospira interrogans adhesion: LigA and LigB bind extracellular matrix proteins and fibrinogen. Infection and Immunity 2007; 75:2441-50.

[44] Hauk P, Macedo F, Romero EC, Vasconcellos SA, de Morais ZM, Barbosa AS et al. In LipL32, the major leptospiral lipoprotein, the $C$ terminus is the primary immunogenic domain and mediates interaction with collagen IV and plasma fibronectin. Infection and Immunity 2008;76:2642-50.

[45] Hoke DE, Egan S, Cullen PA, Adler B. LipL32 is an extracellular matrixinteracting protein of leptospira spp. and pseudoalteromonas tunicata. Infection and Immunity 2008;76:2063-9.

[46] Coleman JL, Benach JL. Use of the plasminogen activation system by microorganisms. The Journal of Laboratory and Clinical Medicine 1999;134:567-76.

[47] Ponting CP, Marshall JM, Cederholm-Williams SA. Plasminogen: a structura review. Blood Coagulation and Fibrinolysis 1992;3:605-14.

[48] Angles-Cano E, Rouy D, Lijnen HR. Plasminogen binding by alpha 2-antiplasmin and histidine-rich glycoprotein does not inhibit plasminogen activation at the surface of fibrin. Biochimica Et Biophysica Acta 1992;1156: 34-42.

[49] Verma A, Brissette CA, Bowman AA, Shah ST, Zipfel PF, Stevenson B. Leptospiral endostatin-like protein $A$ is a bacterial cell surface receptor for human plasminogen. Infection and Immunity 2010;78:2053-9.

[50] Blom AM. Structural and functional studies of complement inhibitor C4bbinding protein. Biochemical Society Transactions 2002;30:978-82.

[51] Gigli I, Fujita T, Nussenzweig V. Modulation of the classical pathway C3 convertase by plasma proteins $\mathrm{C} 4$ binding protein and $\mathrm{C} 3 \mathrm{~b}$ inactivator Proceedings of the National Academy of Sciences of the United States of America 1979;76:6596-600.

[52] Barbosa AS, Monaris D, Silva LB, Morais ZM, Vasconcellos SA, Cianciarullo AM et al. Functional characterization of LcpA, a surface-exposed protein of Leptospira spp. that binds the human complement regulator C4BP. Infection and Immunity 2010;78:3207-16.

[53] Castiblanco-Valencia MM, Fraga TR, Silva LB, Monaris D, Abreu PA, Strobel S et al. Leptospiral immunoglobulin-like proteins interact with human complement regulators factor $\mathrm{H}$, FHL-1, FHR-1, and C4BP. The Journal of Infectious Diseases 2012;205:995-1004.

[54] Verma A, Hellwage J, Artiushin S, Zipfel PF, Kraiczy P, Timoney JF, et al. LfhA a novel factor $\mathrm{H}$-binding protein of Leptospira interrogans. Infection and Immunity 2006;74:2659-66.

[55] Kraiczy P, Skerka C, Brade V, Zipfel PF. Further characterization of complement regulator-acquiring surface proteins of Borrelia burgdorferi. Infection and Immunity 2001;69:7800-9.

[56] Hovis KM, McDowell JV, Griffin L, Marconi RT. Identification and characterization of a linear-plasmid-encoded factor H-binding protein (FhbA) of the relapsing fever spirochete Borrelia hermsii. Journal of Bacteriology 2004;186: 2612-8. 
APÊNDICE C- Artigo publicado no período de desenvolvimento do mestrado: CERQUEIRA, G.M. et al. Development of Transcriptional Fusions to Assess

Leptospira interrogans Promoter Activity. PLoS One., v. 6, p. e17409, 2011. 


\title{
Development of Transcriptional Fusions to Assess Leptospira interrogans Promoter Activity
}

\author{
Gustavo M. Cerqueira ${ }^{1{ }^{*}}$, Natalie M. Souza ${ }^{1}$, Eduardo R. Araújo ${ }^{1}$, Aline T. Barros ${ }^{1}$, Zenaide M. Morais ${ }^{2}$, \\ Sílvio A. Vasconcellos ${ }^{2}$, Ana L. T. O. Nascimento ${ }^{1,3}$
}

1 Centro de Biotecnologia, Instituto Butantan, São Paulo, Brazil, 2 Laboratório de Zoonoses Bacterianas do VPS, Faculdade de Medicina Veterinária e Zootecnia, São Paulo, Brazil, 3 Interunidades em Biotecnologia, Instituto de Ciências Biomédicas, São Paulo, Brazil

\begin{abstract}
Background: Leptospirosis is a zoonotic infectious disease that affects both humans and animals. The existing genetic tools for Leptospira spp. have improved our understanding of the biology of this spirochete as well as the interaction of pathogenic leptospires with the mammalian host. However, new tools are necessary to provide novel and useful information to the field.

Methodology and Principal Findings: A series of promoter-probe vectors carrying a reporter gene encoding green fluorescent protein (GFP) were constructed for use in L. biflexa. They were tested by constructing transcriptional fusions between the lipL41, Leptospiral Immunoglobulin-like A (ligA) and Sphingomielynase 2 (sph2) promoters from L. interrogans and the reporter gene. ligA and sph2 promoters were the most active, in comparison to the lipL41 promoter and the noninduced controls. The results obtained are in agreement with LigA expression from the L. interrogans Fiocruz L1-130 strain.

Conclusions: The novel vectors facilitated the in vitro evaluation of $L$. interrogans promoter activity under defined growth conditions which simulate the mammalian host environment. The fluorescence and rt-PCR data obtained closely reflected transcriptional regulation of the promoters, thus demonstrating the suitability of these vectors for assessing promoter activity in L. biflexa.
\end{abstract}

Citation: Cerqueira GM, Souza NM, Araújo ER, Barros AT, Morais ZM, et al. (2011) Development of Transcriptional Fusions to Assess Leptospira interrogans Promoter Activity. PLoS ONE 6(3): e17409. doi:10.1371/journal.pone.0017409

Editor: Deepak Kaushal, Tulane University, United States of America

Received November 2, 2010; Accepted January 31, 2011; Published March 18, 2011

Copyright: ( $) 2011$ Cerqueira et al. This is an open-access article distributed under the terms of the Creative Commons Attribution License, which permits unrestricted use, distribution, and reproduction in any medium, provided the original author and source are credited.

Funding: Gustavo M. Cerqueira holds a postdoctoral fellowship from the Fundação de Amparo à Pesquisa do Estado de São Paulo (FAPESP). Ana L.T.O. Nascimento would like to acknowledge the support from FAPESP, Conselho Nacional de Desenvolvimento Científico e Tecnológico (CNPq) and Fundação Butantan. The funders had no role in study design, data collection and analysis, decision to publish, or preparation of the manuscript.

Competing Interests: The authors have declared that no competing interests exist.

* E-mail: cerqueiragm@yahoo.com.b

a Current address: Department of Microbiology, Faculty of Medicine, Nursing and Health Sciences, Monash University, Melbourne, Australia

\section{Introduction}

Leptospira interrogans is the main causative agent of leptospirosis, a zoonotic infectious disease with worldwide distribution. Chronically infected reservoir hosts, such as rats, do not exhibit overt disease but are colonized by leptospires in their renal tubules and shed bacteria in the urine. Humans become infected by exposure to contaminated water, soil, or urine [1]. Severe manifestations of the disease, as observed in Weil's disease, are frequent and associated with significant mortality, up to $15 \%[1,2]$. In addition, leptospirosis may evolve to severe pulmonary haemorrhage syndrome (SPHS), for which case fatality is $>50 \%[3,4]$.

The Leptospira genus is composed of 20 recognized species and includes strains that belong to the saprophyte, intermediate or pathogen groups [5]. Currently, almost 300 serovars are recognized, of which more than 200 are considered to be pathogenic $[2,5,6,7]$. The available genome sequences for pathogenic $[8,9,10]$ and saprophytic [11] Leptospira spp. have been employed to search for new diagnostic reagents and vaccine candidates for leptospirosis.

Prompt diagnosis and early treatment of leptospirosis are essential to avoid severe outcomes [12]. The early phase leptospirosis is often misdiagnosed due to its presentation with nonspecific clinical signs [1], low sensitivity and frequent poor specificity of the results exhibited by the microscopic agglutination test (MAT) and the commercially available assays $[7,13,14,15,16,17,18,19]$.

The use of vaccines as prevention measures appears to be a costeffective approach to prevent worldwide diseases. Commercially available whole-cell vaccines confer protection in a limited and incomplete manner, limiting their use among humans. E. g. whole-cell preparations produce only short-term immunity, requiring administration semi-annually; present low cross-protection and adverse reactions due to both residual media components and leptospiral lipopolysaccharide [2,6,7,20,21]. Efforts have been made for over a decade towards identifying immunoreactive $[22,23,24,25,26,27,28]$ or protective $[29,30,31,32,33,34,35,36,37$, $38,39,40,41]$ antigens via recombinant DNA technology. Despite these advances, limitations still remain to be overcome. The rational identification of novel candidate antigens is therefore necessary and the development of genetic tools to Leptospira spp. may be helpful for this purpose.

The mechanisms of Leptospira pathogenesis remain unclear, despite the efforts to identify virulence factors and their role in the 
pathogen-host interaction. To this aim, new genetic tools have been developed in the last years $[11,42,43]$. Functional characterization of outer membrane and cytoplasmic proteins $[44,45,46,47,48,49]$, and more recently the generation and study of knock-out mutants [50,51,52,53,54,55,56] have provided important contribution.

Many efforts have been done to understand the influence of environmental signals on the leptospiral transcriptome and proteome, aiming to identify antigens involved in pathogenesis $[44,46,47,48,57,58]$. Temperature, physiological osmolarity, iron availability and the growth phase, in addition to the multitude of factors existing in the host serum and during pathogen-host cell contact, are known to affect the expression of several leptospiral proteins $[57,58,59,60,61,62]$. $\mathrm{pH}$ was also found to be responsible for protein regulation, such as LipL36 and P31LipL45 (Qlp42), in the kidney tubules of hamsters $[61,63]$. However, many leptospiral coding sequences (CDSs) still remain to be characterized [64]. The L. interrogans genome carries a considerably large number of genes supposedly involved in response regulation [9]. L. borgpetersenii, which possesses a reduced ability to survive outside the host, contains a lower number of regulatory genes [10]. However, the saprophyte L. biflexa contains a larger number of putative transcription factors than the other sequenced species. This suggests that $L$. biflexa can be used as a model to study the gene regulation of pathogenic Leptospira spp. [11,57]. Despite the sequence diversity between both species, these findings suggest that pathogens and saprophytes might share some similar mechanisms to respond to the environment.

The extent to which the manipulation of in vitro conditions can be used to reproduce the full spectrum of mammalian host signals, which trigger differential gene expression in pathogenic Leptospira spp. remains uncertain. In this study, we sought to develop a new genetic tool to help elucidating the biology of Leptospira spp. We found that our promoter-probe methodology is useful for assessing promoter activity under defined conditions. The comparative analysis of the fluorescence produced by a specific L. biflexa reporter strain, PAG (carrying a copy of the ligA promoter fused to the $g f p$ gene), and LigA expression from L. interrogans Fiocruz L1130 strain, grown in vitro under the same systematic conditions, validated the use of $L$. biflexa as a model to assess $L$. interrogans promoter activity. The reporter strain containing a copy of the sphingomyelinase 2 promoter, Psph2 (P2G) was also strongly induced by the conditions tested, above an established cut-off, whereas the non-virulence factor promoter control, from the lipL41 lipoprotein gene, was not. We believe this promoter-probe methodology may support the existing methodologies to the identification of novel virulence factors of pathogenic Leptospira spp.

\section{Methods}

\section{Bacterial strains and growth conditions}

Bacterial strains and constructs are listed in Table 1. Strains were obtained from the collection of the Faculdade de Medicina Veterinária e Zootecnia, Universidade de São Paulo, São Paulo, Brazil; Laboratoire de Biologie des Spirochetes, Institut Pasteur, Paris, France and the ATCG. The virulence of the low-passage $L$. interrogans serovar Copenhageni Fiocruz L1-130 strain was maintained by passage through Golden Syrian hamsters. Lowpassage refers to strains that were sub-cultured in EMJH liquid medium up to 10 times. All strains were cultured at $30^{\circ} \mathrm{C}$ in liquid EMJH medium supplemented with $1 \%$ rabbit serum $[65,66]$. Chemically competent $E$. coli TOP10F cells were used as host for genetic manipulation of plasmids. E. coli transformants were typically selected on LB agar plates containing spectinomycin $(50 \mu \mathrm{g} / \mathrm{ml})$ or ampicillin $(100 \mu \mathrm{g} / \mathrm{ml})$. Electrocompetent L. biflexa sorovar Patoc strain Patoc 1 was prepared as previously described [55], and transformed with replicating shuttle vectors containing the promoter-probe cassettes (Table 1). EMJH plates were prepared using $1 \%$ agar and supplemented with spectinomycin at $50 \mu \mathrm{g} / \mathrm{ml}$.

Liquid EMJH pH 6.7 was prepared by adding concentrated $\mathrm{HCl}$ until the $\mathrm{pH}$ of choice was reached. Spermine (Sigma) was dissolved according to the manufacturer's instructions and supplemented in cultures at $200 \mu \mathrm{M}$. Physiologic osmolarity was induced by supplementation with $120 \mathrm{mM} \mathrm{NaCl}$ [44]. Before induction, cultures were grown at $30^{\circ} \mathrm{C}$ in $\mathrm{EMJH}$ until the lateexponential phase was reached (culture density of $10^{8}$ to $10^{9} / \mathrm{ml}$ ). Growth was monitored by measuring the $\mathrm{OD}_{420}$ using an Ultrospec 2100 pro spectrophotometer (GE Healthcare). Cells were harvested $\left(\mathrm{OD}_{420} 0.5\right)$ and immediately stored at $-20^{\circ} \mathrm{C}$.

\section{Bioinformatics analyses}

The sequences used for this study were obtained from the complete genome sequence of $L$. interrogans serovar Copenhageni strain Fiocruz L1-130 by using the SpiroScope (http://www. genoscope.cns.fr/agc/mage) database [67] and Leptospira Genome Project (http://aeg.lbi.ic.unicamp.br) database [9]. The Neural Network Promoter Prediction v.2.2 [68], TRES - Transcription Regulatory Element Search, which performs searches within the TRANSFAC database [69] and the PromScan program, that generates an alignment of known sequences and matrix frequency [70], were used to scan DNA sequences for potential binding sites. Repeats were identified by the EMBOSS programs available at http://bioweb.pasteur.fr/nucleic/intro-en.html\#repeat.

\section{Construction of reporter vectors}

The $g f p$ gene [43] was amplified by PCR with Gfp5/Gfp3 primers pair, which introduced the SmaI, SacI, XhoI, BamHI, SmaI restriction sites. The resulting fragment was cloned into pGEM-T Easy (Promega) yielding the pGEM-T Easy/gfp construct. The PlipL41, PligA and Psph2 promoters from $L$. interrogans serovar Copenhageni strain Fiocruz L1-130 were amplified by PCR using primers PlipL41300F/PlipL41300R, PligA300F/PligA300R and Psph2600F/Psph2600R, which introduced the $X h o \mathrm{I}$ and $\mathrm{BamHI}$ restriction sites, and cloned into pGEM-T Easy $/ g f p$ via the same sites. Promoter-probe vectors containing the L. interrogans promoters- $g f p$ cassettes were constructed in the E. coli-L. biflexa pSLe94 shuttle-vector [71]. The cassettes were removed from pGEM-T Easy (Promega) by SmaI digestion and cloned in via PvuII restriction site to give the new vectors, pSLe94/PlipL41/gfp, pSLe94/PligA/gfp and pSLe94/Psph2/gfp (Table 1). Electroporation of leptospires was performed as previously described [55,71]. After 1 to 2 weeks of incubation, spectinomycin resistant transformants were used to inoculate liquid medium.

\section{Reporter gene assays}

Cells for spectrofluorometry measurements were resuspended in $300 \mu \mathrm{l}$ of deionized water and distributed $100 \mu \mathrm{l}$ per well in a black 96-well OptiPlate-96F microplate (PerkinElmer). GFP fluorescence was measured using a 650-10 spectrofluorometer (PerkinElmer) at an excitation wavelength of $485 \mathrm{~nm}$ and an emission wavelength of $538 \mathrm{~nm}$. The fluorescence intensity from samples was expressed as arbitrary fluorescence units, obtained at a wavelength of maximum emission. The mean specific activity from at least three independent assays is indicated in the results. 
Table 1. Primers, plasmids and strains employed in this study.

\begin{tabular}{|c|c|}
\hline Designation & Sequence $\left(5^{\prime}-3^{\prime}\right) /$ genotype \\
\hline \multicolumn{2}{|l|}{ PRIMERS } \\
\hline PlipL41300F & CCGCTCGAGAGATAAGATCCAACCCAAAAGTTG \\
\hline PlipL41300R & GGCGGATCCATGAAAAGTAACACCAATCCTGTTTGA \\
\hline PligA300F & CCGCTCGAGTTGGTTITATAGAAATCAGCAATGATCC \\
\hline PligA300R & GGCGGATCCATAAACACTCACTCTAATTGTTTTATTTGAA \\
\hline Psph2600F & CCGCTCGAGAAACAAAGAATACATACTATAACGTGAATTC \\
\hline Psph2600R & GGCGGATCCATCGTCTCTATCTCCATTCTGTATGTTTG \\
\hline Gfp5 & GTCGACGAGCTCGAGGGATCCATGAGTAAAGGAGAAGAA \\
\hline Gfp3 & TCAGATCTATTTGTGATGGTGATGGTGATGGTATAGTTCATCC \\
\hline fD1 & AGAGTTTGATCYTGGYTYAG \\
\hline rP2 & ACGGCTACCTTGTTACGACTT \\
\hline NligA5 & GCGGATCCTCCGTTACCGCAGCGGAACTTACTGAGAT \\
\hline NligA3 & CCCAAGCTITTACCAGGCTCGATTACTTTT \\
\hline \multicolumn{2}{|l|}{ PLASMIDS } \\
\hline pGem-T easy & TA cloning vector; $\mathrm{Amp}^{r}$ \\
\hline pGem-T easy/gfp & pGem-T easy carrying a copy of the $g f p$ gene \\
\hline pGem-T easy/PlipL41/gfp & pGem-T easy/gfp carrying a copy of the PlipL41 promoter upstream gfp \\
\hline pGem-T easy/PligA/gfp & pGem-T easy/gfp carrying a copy of the PligA promoter upstream $g f p$ \\
\hline pGem-T easy/Psph2/gfp & pGem-T easy/gfp carrying a copy of the $P s p h 2$ promoter upstream gfp \\
\hline pSLe94 & E. coli/L. biflexa shuttle vector; $\mathrm{Spc}^{r}$ \\
\hline pSLe94/PlipL41/gfp & E. coli/L. biflexa shuttle vector carrying the cassete PlipL41 promoter-gfp \\
\hline pSLe94/PligA/gfp & E. coli/L. biflexa shuttle vector carrying the cassete PligA promoter-gfp \\
\hline pSLe94/Psph2/gfp & E. coli/L. biflexa shuttle vector carrying the cassete $P$ sph2 promoter-gfp \\
\hline \multicolumn{2}{|l|}{ STRAINS } \\
\hline Escherichia coli Top 10 & 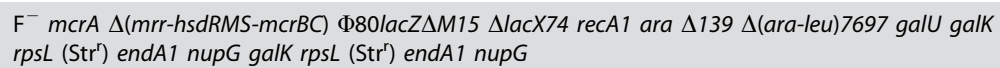 \\
\hline L. biflexa sv. Patoc str. Patoc1 & Wild-type saprophytic strain \\
\hline L. interogans sv. Copenhageni str. Fiocruz L1-130 & Wild-type pathogenic strain \\
\hline P41G & Str. Patoc1 carrying the pSLe94/PlipL41/gfp shuttle vector \\
\hline PAG & Str. Patoc1 carrying the pSLe94/PligA/gfp shuttle vector \\
\hline P2G & Str. Patoc1 carrying the pSLe94/Psph2/gfp shuttle vector \\
\hline
\end{tabular}

\section{Fluorescence microscopy}

Qualitative expression of GFP was examined under UV light for detection of fluorescence. The cultures were induced and samples were collected at representative time-points, spun down and the resulting pellets were washed twice with $1 \times$ PBS to remove the culture medium. The pellets were then resuspended in $1 \times \mathrm{PBS}$, $20 \%$ Glycerol. Aliquots of $20 \mu \mathrm{l}$ of the bacterial suspensions were applied to slides and sealed with a concentrated formaldehyde resin. Images of leptospires on cover slips were acquired using an IX81 inverted microscope (Olympus) equipped with $20 \times$ and $40 \times$ objectives and the CellR software (version 3.1). The UV filter sets used were DAPI (excitation: $350 \mathrm{~nm}$ - range is 330 to $380 \mathrm{~nm}$, Emission: $460 \mathrm{~nm}$ ) and DIC (transmitted light).

\section{RNA isolation and rt-PCR}

Cells were harvested $\left(\mathrm{OD}_{420} 0.25\right)$ and RNA was isolated from bacteria with TRIzol reagent (Invitrogen), as described by the manufacturer. Then, isolated RNA $(2 \mu \mathrm{g})$ was treated with
DNaseI (Invitrogen), following manufacturer's instructions. cDNA was synthesized using SuperScript III First-strand (Invitrogen) according to the manufacturer's protocol. Samples were quantified and checked for purity using an Ultrospec 2100 pro spectrophotometer (GE healthcare) and agarose gel electrophoresis. The cDNA (representing $100 \mathrm{ng}$ of RNA per reaction) was amplified with Taq DNA polymerase (Invitrogen) using primers pairs fD1/ rP2 (control) [72], Gfp5/Gfp3 for reporter strains [43], or NligA5/ NligA3, for L. interrogans serovar Copenhageni strain Fiocruz L1-130.

\section{Whole-cell ELISA}

Whole-cell ELISA experiments were performed using a modification of previously described methods [45,73]. Flat-bottom polystyrene high-binding microtitre plates (Corning) were coated overnight at $4^{\circ} \mathrm{C}$ with $100 \mathrm{ml}$ per well of $10^{8} \mathrm{ml}^{-1}$ whole $L$. interrogans serovar Copenhageni strain Fiocruz L1-130, which were previously centrifuged at $4,000 \times \mathrm{g}$ and resuspended in $0.05 \mathrm{M}$ 
sodium carbonate buffer ( $\mathrm{pH}$ 9.6). Plates were blocked overnight at $4^{\circ} \mathrm{C}$, and washed three times with $150 \mu$ Leptospira Enrichment EMJH (Difco). Wells were incubated for $1 \mathrm{~h}$ at room temperature with $100 \mu \mathrm{l}$ per well of a 1:2,000 dilution of rabbit anti-LigA polyclonal serum (Kindly provided by Dr. Albert I. Ko and Dr. Paula Ristow, Gonçalo Moniz Research Centre, Oswaldo Cruz Foundation, Brazil) in Leptospira Enrichment EMJH, and washed three times with $200 \mu \mathrm{l}$ PBS containing $0.05 \%$ Tween 20 (PBS-T). Wells were incubated with $100 \mu \mathrm{l}$ per well of a 1:5,000 dilution of horseradish-peroxidase-linked donkey whole-antibody anti-rabbit IgG (Sigma) for $1 \mathrm{~h}$ at room temperature, followed by two washes with $200 \mathrm{ml}$ PBS-T, and three washes with PBS. The reactions were developed by adding $50 \mu \mathrm{l}$ per well of o-phenylenediamine $(\mathrm{OPD})(1 \mathrm{mg} / \mathrm{ml})$ in citrate phosphate buffer $(\mathrm{pH} 5.0)$ plus $1 \mu \mathrm{l} / \mathrm{ml}$ $\mathrm{H}_{2} \mathrm{O}_{2}$ was added $(100 \mu \mathrm{l}$ per well) for $10 \mathrm{~min}$ in the dark, at room temperature. The reaction was stopped by adding a $50 \mu \mathrm{l}$ volume of $4 \mathrm{M} \mathrm{H}_{2} \mathrm{SO}_{4}$, and the absorbance was measured at $492 \mathrm{~nm}$. Each ELISA experiment was repeated three times.

\section{Statistical analysis}

Differences between average values were tested for significance by performing an unpaired, two-sided Student's t-test [74]. Differences were considered statistically significant when the resulting $p$ values were $\leq 0.05$.

\section{Results}

In vitro induction of virulent Leptospira interrogans

Many efforts have been made to identify and quantify the leptospiral transcriptome and proteome during growth under different conditions. But, so far, little is known about the influence that mammalian host conditions exert over promoter activity. Therefore, we initiated our investigation by studying ligA gene transcription and protein expression profiles using $L$. interrogans serovar Copenhageni strain Fiocruz L1-130 grown, for up to 24 h, under a combination of conditions that include the mammalian physiological osmolarity ( 300 mosmol-120 mM), temperature $\left(37^{\circ} \mathrm{C}\right)$, urine $\mathrm{pH}(6.7)$ and the supplementation with spermine, a component belonging to the intracellular environment. We focused our study on the first $24 \mathrm{~h}$ of induction, to observe the changes that $L$. interrogans promoters undergo during the early stages of host invasion.

Initially, we evaluated the influence of the different conditions by rt-PCR analysis (Figure 1). It was performed on RNA extracted from both non-induced and induced cultures of the virulent, low- passage, L. interrogans serovar Copenhageni strain Fiocruz L1-130. Low level transcription (ligA-based) was detected before induction of the virulent strain, while a clear difference in the abundance of $\operatorname{lig} A$ transcript could be seen after induction, and between the time intervals. Three time-points were evaluated (1, 12 and $24 \mathrm{~h}$ post induction - p.i.) and, interestingly, ligA transcription was not constant after induction (Figure 1). Under most conditions, the level of ligA transcript was higher than the non-induced control immediately one hour p.i. However, only spermine was able to upregulate ligA for an extended period, up to $12 \mathrm{~h}$ p.i., while the other treatments exhibited down-regulation (Figure 1). At $24 \mathrm{~h}$ p.i., only the temperature upshift and physiological osmolarity conditions stimulated up-regulation in comparison to the previous time-point (Figure 1).

To examine the effect of the conditions over the expression patterns of native LigA, we cultivated $L$. interrogans serovar Copenhageni strain Fiocruz L1-130 until late-exponential phase before induction. The combination of both temperature upshift and physiological osmolarity promoted induction of protein synthesis (Figure 2A). An up-regulation 4.98-fold higher than the non-induced control was observed at one hour p.i. $(p<0.01)$. The influence of spermine was also evaluated in the kinetics assay and stimulated LigA expression above the control levels immediately after induction, one hour p.i. (5.95-fold, $\mathrm{p}<0.01$ ), (Figure 2B). The urine $\mathrm{pH}$ condition was simulated by reducing the $\mathrm{pH}$ from 7.2 to 6.7 and the highest up-regulation was obtained by this treatment, one hour p.i. (5.92-fold, p<0.01), (Figure 2C). But it was the only condition to be followed by decreasing expression levels. The analysis of native LigA expression complemented the results obtained by rt-PCR, although correlation was not always observed between RNA and protein profiles (Figure 1 versus 2).

\section{Prediction of regulatory sequences by Bioinformatics}

Previous studies demonstrated that upon induction by physiological osmolarity and temperature shift from $20^{\circ} \mathrm{C}$ to $37^{\circ} \mathrm{C}$ and $30^{\circ} \mathrm{C}$ to $37^{\circ} \mathrm{C}$ the lipL41, ligA and sph2 genes are differentially expressed in L. interrogans serovar Copenhageni strain Fiocruz L1130, L. kirschneri serovar Grippotyphosa strain RM52 and $L$. interrogans serovar Lai strain 56601 [44,46,47,48]. The rational to select the PlipL41, PligA and Psph2 promoters to compose and standardize our study was based on previous studies that characterized them extensively at the RNA and protein levels.

The PlipL41, PligA and Psph2 promoters were predicted by bioinformatics based on the analysis of the L. interrogans serovar Copenhageni strain Fiocruz L1-130 genome sequence

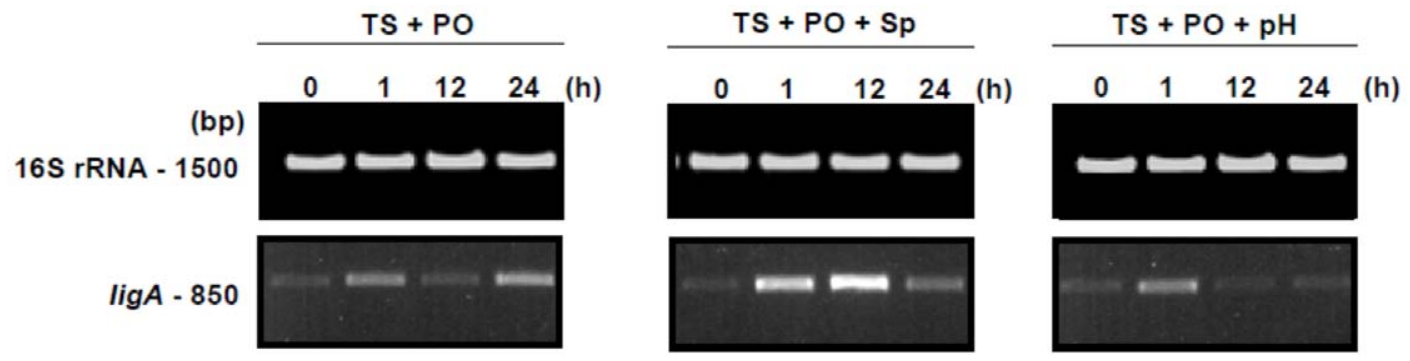

Figure 1. Influence of the in vitro conditions on native LigA expression by L. interrogans serovar Copenhageni str. Fiocruz L1-130. The effect of the various combinations of conditions (see Results section) on LigA expression was assessed by rt-PCR. Columns depict the systematic treatments: TS - Temperature upshift from $30^{\circ} \mathrm{C}$ to $37^{\circ} \mathrm{C}, \mathrm{PO}$ - Physiological osmolarity, Sp - Spermine induction, $\mathrm{pH}$ - Urine pH induction. Within each gel the upper and lower bands correspond to the internal PCR control (16S rRNA) and ligA cDNA, respectively (domains 10-12). The lanes contain the amplified cDNA per sample time-point, both pre-treatment $(0 \mathrm{~h})$ and post induction $(1,12$ and $24 \mathrm{~h})$. Agarose gels were stained with GelRed (Invitrogen). No bands were observed in control samples run without template (data not shown). Samples were standardized according to an $\mathrm{OD}_{420}$ 0.25. Data from a representative significant study are shown.

doi:10.1371/journal.pone.0017409.g001 

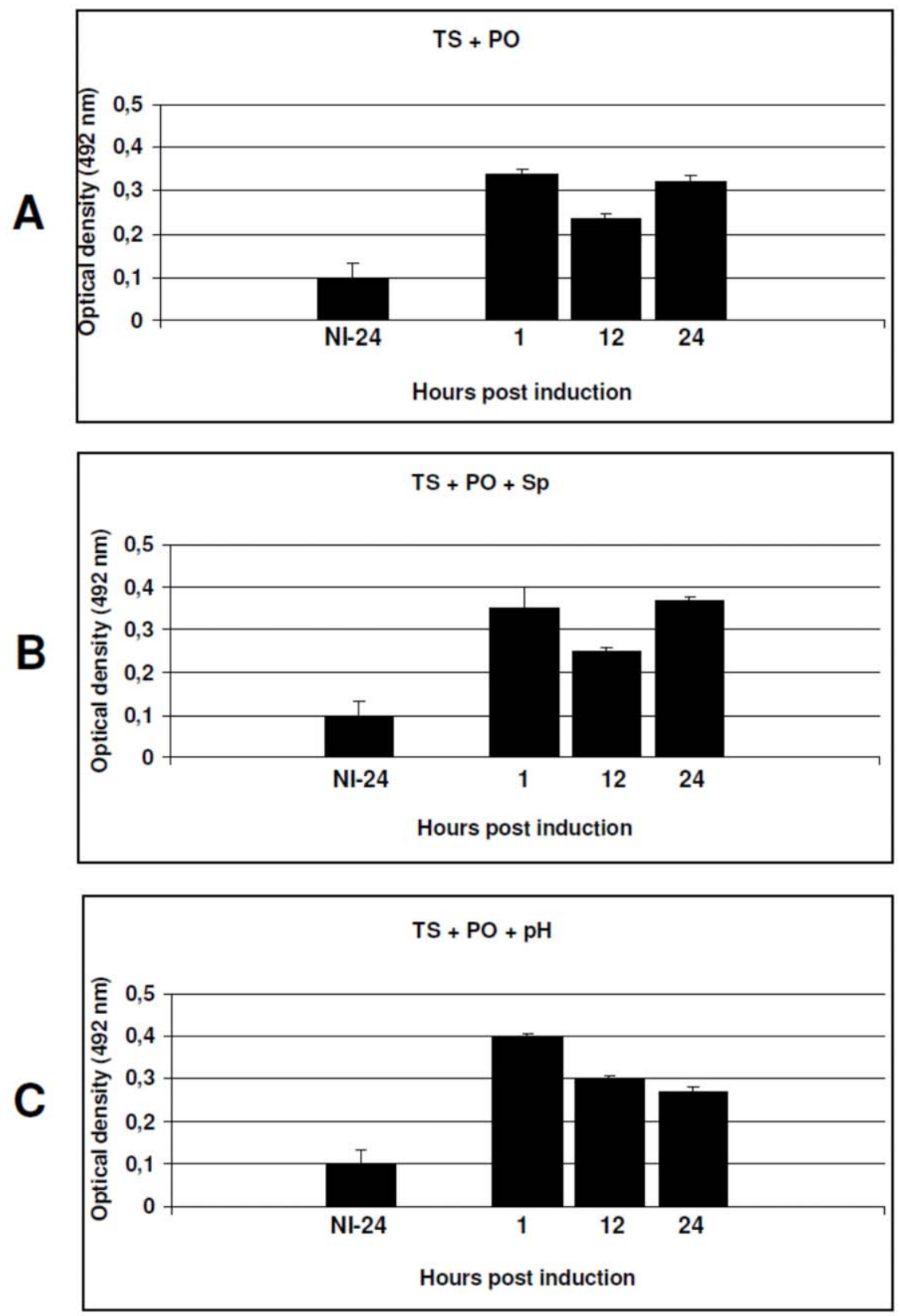

Figure 2. Native protein expression stimulated by the in vitro conditions mimicking those of the mammalian host. The expression levels of LigA were evaluated by ELISA, following exposure to the various conditions and combinations: TS - Temperature upshift from $30^{\circ} \mathrm{C}$ to $37^{\circ} \mathrm{C}$, $\mathrm{PO}$ - Physiological osmolarity, Sp - Spermine induction, $\mathrm{pH}$ - Urine $\mathrm{pH}$ induction. (A) Temperature upshift and physiological osmolarity. (B) Temperature upshift, physiological osmolarity and spermine (intracellular level). (C) Temperature upshift, physiological osmolarity and pH reduction from 7.2 to 6.7. A non-induced L. interrogans serovar Copenhageni str. Fiocruz L1-130 (NI-24) was cultivated in vitro for $24 \mathrm{~h}$ under standard conditions as a control. Protein expression was measured at one, 12 and $24 \mathrm{~h}$ post-induction and the results are expressed as mean optical density \pm standard error (bars). The assay was standardized according to an $\mathrm{OD}_{420}$ of 0.25 . Data from two independent and significant experiments are shown. doi:10.1371/journal.pone.0017409.g002

(AE016823). Different regions were identified, which are composed of direct and inverted repeats (data not shown).

To examine whether the computationally determined sequences comprise leptospiral regulatory elements, we fused the DNA segments to a promoterless gfp reporter. Both elements were subsequently cloned into an E. coli-L. biflexa shuttle vector depicted in Table 1, yielding the plasmids pSLe94/PlipL41/gfp, pSLe94/ $P l i g A / g f p$ and pSLe94/Psph2/gfp (Table 1). To ensure the accurate inclusion of the DNA sequences containing the regulatory elements in the study, we designed primers to amplify $300 \mathrm{bp}$ upstream of the first ATG of lipL41 and ligA, and $600 \mathrm{bp}$ upstream of sph2. The larger length of the amplified fragment upstream of $s p h 2$ was adopted to include possible distal elements that may play a role in the activity of the $P s p h 2$ promoter, since the intergenic space to the next ORF, LIC12630 (hypothetical protein), is $650 \mathrm{bp}$. In the case of the lipL41 and ligA genes the intergenic spaces are $114 \mathrm{bp}$ and $456 \mathrm{bp}$, respectively. The plasmid constructs were used to transform $L$. biflexa serovar Patoc strain Patoc I and generated the reporter strains P41G (lipL41 promoter), PAG (ligA promoter) and P2G (sph2 promoter), which were 
induced for production of fluorescence by the green fluorescent protein $(\mathrm{GFP})$.

\section{Application of promoter-probe vectors in L. biflexa}

A series of replicating promoter-probe vectors utilizing $g f p$ were constructed to examine changes in promoter activity in response to a set of defined conditions (Table 1). The constructs were based on the low-copy number shuttle-vector pSLe94 (Table 1), which contains the LE1 origin of replication that is capable of replication within saprophytic Leptospira spp. To validate the usefulness of these vectors as genetic tools to investigate promoter regulation, transcriptional fusions were constructed including the promoters from the well-characterized genes lipL41, ligA and sph2 of $L$. interrogans serovar Copenhageni strain L1-130. GFP reporter strains were established by electroporation of the promoterspecific reporter vectors into $L$. biflexa. The effectiveness of the reporter strains for assaying transcriptional activity was assessed quantitatively.

All three reporter strains of $L$. biflexa were initially cultivated on EMJH agar plates, at $30^{\circ} \mathrm{C}$, and then transferred to liquid EMJH, both containing low-salt concentration $(70$ mosmol per liter $\mathrm{NaCl}$ $-28 \mathrm{mM}$ ). When cultures reached the late-exponential phase they were aliquoted and either adjusted to $120 \mathrm{mM} \mathrm{NaCl}$ or temperature-upshfited from $30^{\circ} \mathrm{C}$ to $37^{\circ} \mathrm{C}$. Quantitative assessment of fluorescence showed that, under physiological osmolarity conditions, the highest promoter activity was detected in the PAG reporter strain, compared to the control, $\mathrm{p}<0.01$ (Figure 3). The PligA promoter was induced in the presence of $120 \mathrm{mM} \mathrm{NaCl}$ and the fluorescence reached the highest level 3 hours p.i. The average intensity at this time-point was 1.48-fold higher than the noninduced control (Figure 3B). Neither the PlipL41 nor Psph2 promoters were significantly induced (Figure 3A and 3C). Of note, there were no obvious differences between the growth curves of the wild-type and the reporter strains of $L$. biflexa, suggesting that the GFP expression did not cause any disadvantage to the host strain (data not shown).

The influence of the temperature upshift, from $30^{\circ} \mathrm{C}$ to $37^{\circ} \mathrm{C}$, on promoter activity was also assessed. The levels of fluorescence produced by the $\mathrm{P} 41 \mathrm{G}, \mathrm{PAG}$ and $\mathrm{P} 2 \mathrm{G}$ reporter strains were significantly higher than the non-induced controls $(\mathrm{p}<0.01)$. The PlipL41 and Psph2 promoters reached their maximum activity 3 hours p.i. (Figure $4 \mathrm{~A}$ and $4 \mathrm{C}$ ). At this time point there was significant $(\mathrm{p}<0.01)$ up-regulation of 1.46 -fold and 1.26-fold, respectively. The $\mathrm{P} 41 \mathrm{G}$ reporter strain exhibited the highest promoter activity, under this condition, followed by P2G. PligA promoter activity was most influenced, with expression 1.50 -fold higher than the non-induced control, $\mathrm{p}<0.01$. Interestingly, PligA and $P s p h 2$ activities remained constant during the assay conditions (Figure 4B and 4C). The induction of PlipL41 and Psph2 by the temperature upshift led to production of fluorescence levels significantly higher than those induced under conditions of physiological osmolarity, $\mathrm{p}<0.05$ (Figure $3 \mathrm{~A}$ versus $4 \mathrm{~A}$ and $3 \mathrm{C}$ versus $4 \mathrm{C}$ ), while the PligA activity induced by the temperature upshift did not differ from that observed by salt supplementation, at most of the time-points investigated (Figure 3B versus 4B).

\section{Effect of the combination of environmental signals on L. interrogans promoter activity}

To identify promoters that are differentially induced in response to a combination of conditions, we performed systematic experiments with different, overlapping, stimuli. Subcultures were initially induced under conditions of physiological osmolarity and normal human body core temperature $\left(37^{\circ} \mathrm{C}\right)$. The average fluorescence intensity produced by the reporter strains was highly significant when compared to the non-induced controls, $\mathrm{p}<0.01$. For P41G, the highest promoter activity was observed 3 hours p.i. (1.54-fold), and remained constant throughout the assay (Figure 5A). Both PligA and Psph2 were induced to the highest levels 1 hour p.i., 2.59-fold and 1.62, respectively $(\mathrm{p}<0.01)$. However, they did not maintain a constant activity during the assay (Figure 5B and 5C). Additionally, PlipL41 was induced to a similar extent by the temperature upshift and the combination of physiological osmolarity and temperature (Figure $4 \mathrm{~A}$ versus $5 \mathrm{~A}$ ). PligA and Psph2 were significantly induced, 1.74-fold and 1.57-fold, respectively (Figure $3 \mathrm{~B}$ versus $5 \mathrm{~B}$ and $3 \mathrm{C}$ versus $5 \mathrm{C}$ ), and 1.73 -fold and 1.28 -fold, respectively (Figure $4 \mathrm{~B}$ versus $5 \mathrm{~B}$ and $4 \mathrm{C}$ versus $5 \mathrm{C}$ ), compared to the single-condition treatments (physiological osmolarity or temperature upshift versus their combination).

The results indicate these promoters were preferentially active, in vitro, when L. biflexa was cultured under conditions emulating the mammalian host environment. Thus, we decided to evaluate another combination of conditions, the effect of the urine $\mathrm{pH}$ plus the physiological osmolarity and the temperature upshift. The reporter strains were sub-cultured into EMJH medium supplemented with $120 \mathrm{mM} \mathrm{NaCl}, \mathrm{pH} 6.7$, and shifted from $30^{\circ} \mathrm{C}$ to $37^{\circ} \mathrm{C}$. This resulted in the activation of all promoters as seen by increasing levels of fluorescence. The results from three independent experiments are shown in Figure 6. The PligA promoter was the most affected, reaching an activity 2.08-fold higher than the non-induced control ( 3 hours p.i.), followed by Psph2 (1.96-fold) and PLipL41 (1.58-fold), both at 24 hours p.i, p $<0.01$ (Figure 6). Curiously, we observed that both PligA and PlipL41 were slightly less stimulated by the combination that included $\mathrm{pH} 6.7$ than that including salt and temperature only $(\mathrm{p}<0.05)$ (Figure $5 \mathrm{~A}$ versus $6 \mathrm{~A}$ and $5 \mathrm{~B}$ versus $6 \mathrm{~B})$.

Previous studies have demonstrated that several bacteria undergo translational regulation in response to spermine [75]. This polyamine is only produced by eukaryotic cells, it can reach millimolar levels within them [76], and it has significant effects on various cellular processes in liver, kidney and brain cells and in lymphocytes $[76,77,78,79,80,81,82]$. Here, we investigated whether spermine contributed to $L$. interrogans promoter regulation. The L. biflexa reporter strains were grown at $30^{\circ} \mathrm{C}$ until late-exponential phase and then supplemented with $200 \mu \mathrm{M}$ spermine, $120 \mathrm{mM}$ $\mathrm{NaCl}$ and upshifted to $37^{\circ} \mathrm{C}$. The ligA promoter was the most affected, the PAG reporter strain produced a fluorescence level 2.74-fold higher than the non-induced control (3 hours p.i.), followed by P2G (2.12-fold) and P41G (1.58-fold), both 24 hours p.i, $\mathrm{p}<0.01$ (Figure 7). However, ligA promoter activity was not maintained, the average fluorescence decreased to 1.72 -fold (24 hours p.i.), demonstrating that PligA is transiently induced by spermine (Figure 7B). The spermine-induced activity of both PligA and Psph2 promoters was the highest observed in this study (Figure $7 \mathrm{~B}$ and $7 \mathrm{C}$ ).

In agreement with the native LigA expression pattern, the fluorescence produced by the PAG reporter strain reached the highest (4.98-fold versus 2.59-fold) and lowest (2.19-fold versus 2.13-fold) levels at one and 12 hours p.i., respectively, when induced by the combination of physiological osmolarity and temperature upshift (Figure 2A versus $5 \mathrm{~B}$ and Table 2), while the LigA expression pattern induced by spermine was different from the fluorescence intensity produced by the PAG reporter strain (Figure 2B versus 7B). Finally, induction by $\mathrm{pH} 6.7$ led to LigA expression that was consistent with the fluorescence levels produced by the PAG reporter strain (Figure $2 \mathrm{C}$ versus $6 \mathrm{~B}$ and Table 2). Protein and fluorescence levels were highest one hour p.i., but the amount of native LigA decreased significantly (from 5.95-fold to 4.04-fold), while the fluorescence level produced by 

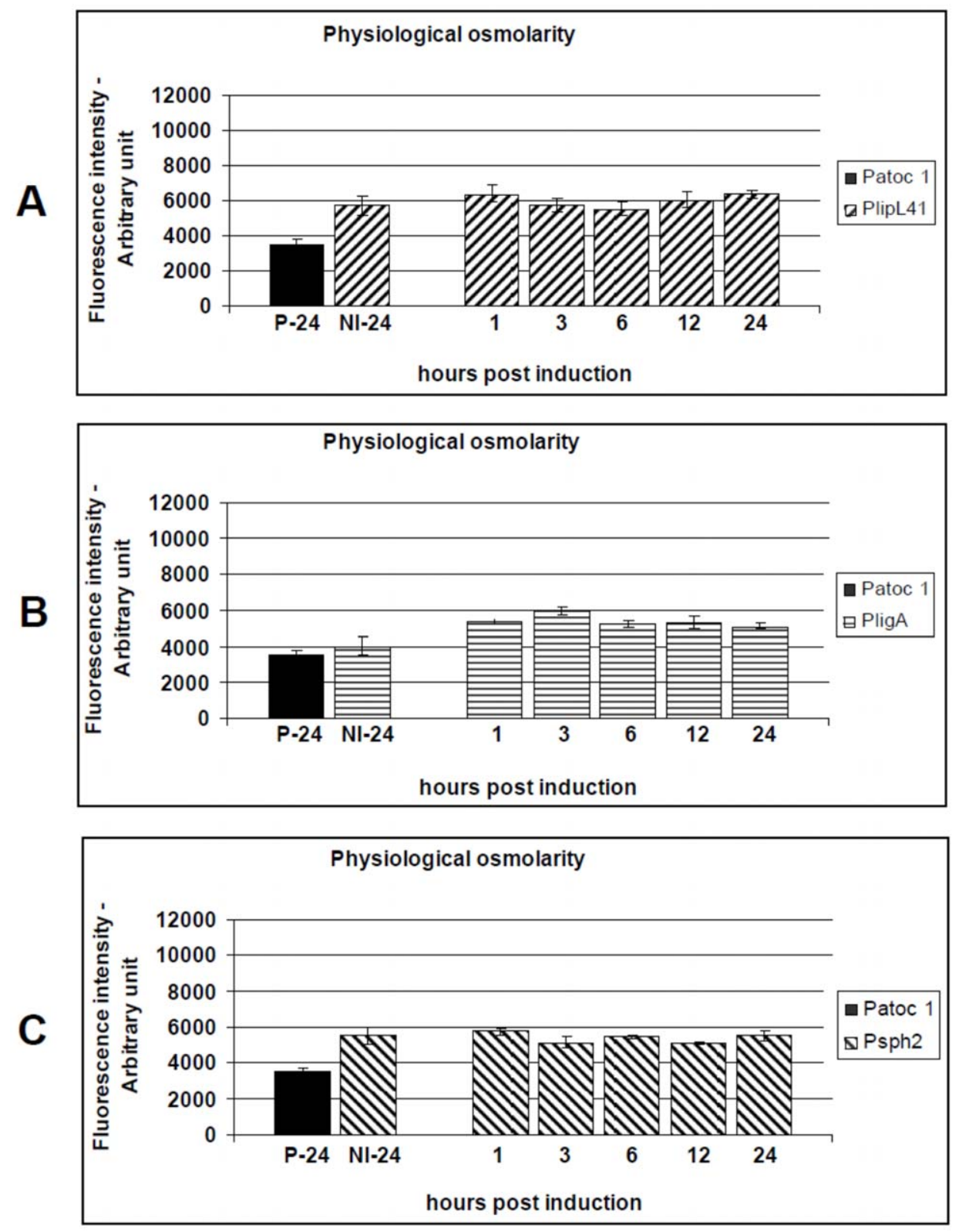

Figure 3. Kinetics of GFP production by the L. biflexa reporter strains (P41G, PAG and P2G) following induction by NaCl to a physiological level. Cultures of the reporter strains containing a single-copy transcriptional reporter and either the wild-type lipL41 (A), ligA (B) or sph2 (C) promoter regions were induced with $\sim 300$ mosmol NaCl (physiological level). An induced non-transformed L. biflexa serovar Patoc str. Patoc 1 (P-24) was induced for $24 \mathrm{~h}$ as a control. The uninduced reporter strains (NI-24) were included as additional controls. Transcriptional activity was presented as the mean \pm standard error (bars). Fluorescence levels from triplicate samples of each culture were standardized according to an $\mathrm{OD}_{420}$ 0.5 and are expressed as arbitrary fluorescence units. Data from a representative significant study are shown. doi:10.1371/journal.pone.0017409.g003

the PAG reporter strain remained constant (from 2.07-fold to 2.03-fold). The results obtained in this study, by the use of the promoter-probe methodology described, allowed us to establish a cut-off based on the determined fluorescence levels (Table 2). This information will be useful to support the future prediction of virulence factors as we are currently developing a follow-up study employing several other promoter sequences to construct a library of knock-in mutants.

The ability of the promoter-probe system to allow for the differentiation between both non-induced and induced reporter strains suggests that the $g f p$ regulation can be employed to accurately mimic the behaviour of the native genes. This is corroborated by similarities observed between the expression patterns of native LigA and the fluorescence levels produced by the PAG reporter strain, in comparison to the non-induced controls (Table 2). Qualitative assessment of these reporter strains clearly demonstrated the presence of fluorescent leptospires upon induction in vitro (Figure 8).

To further substantiate the data obtained by the use of the promoter-probe vectors, rt-PCR analysis was performed on RNA extracted from non-induced and induced cultures of the L. biflexa reporter strains (Figure 9). As expected, low level of transcripts $(g f p$ based) were detected before induction of the reporter strains. Three time-points were evaluated, 1, 3 or 6 and 24 h p.i., but only 

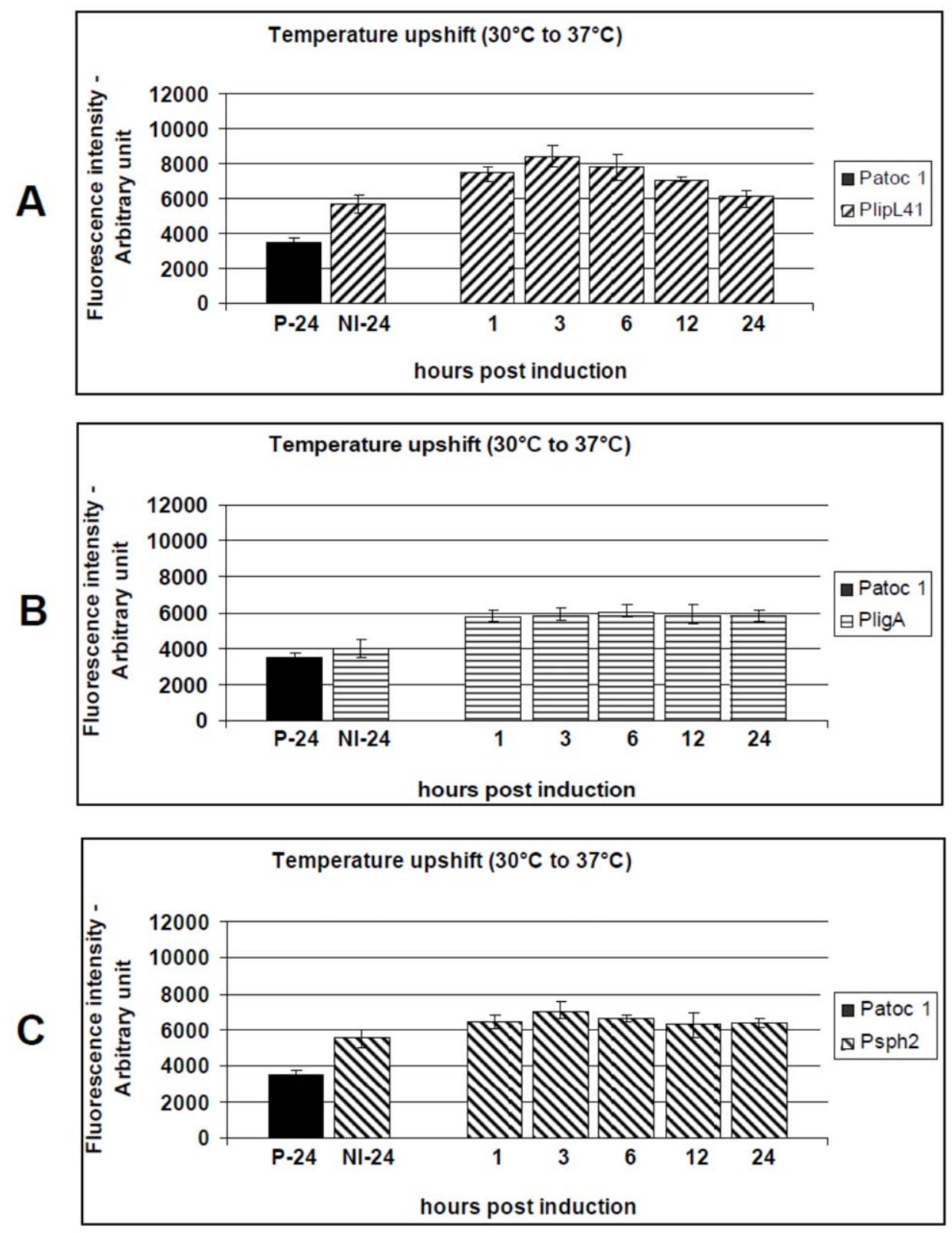

Figure 4. Kinetics of GFP production by the L. biflexa reporter strains (P41G, PAG and P2G) after a temperature upshift to $37^{\circ} \mathrm{C}$. Cultures of the reporter strains P41G (A), PAG (B) or P2G (C) were induced by temperature upshift from $30^{\circ} \mathrm{C}$ to $37^{\circ} \mathrm{C}$ (physiological temperature). $L$. biflexa serovar Patoc str. Patoc 1 (P-24) induced for $24 \mathrm{~h}$ and uninduced reporter strains grown (NI-24) were included as controls. Transcriptional activity was measured for $24 \mathrm{~h}$ and presented as the mean \pm standard error (bars). Fluorescence from triplicate samples of each culture were standardized according to an $\mathrm{OD}_{420} 0.5$ and are expressed as arbitrary fluorescence units. Data from a representative significant study are shown. doi:10.1371/journal.pone.0017409.g004

a slight difference was observed between the time-points for any given in vitro treatment, per reporter strain (Figure 9). Despite this, the amount of $g f p$ mRNA varied considerably per treatment. Correlation between the fluorescence and transcription levels was not always evident, similarly to the lack of correlation observed during the analysis of the native strain (see Results). In both cases (native and reporter strains) the discrepancy observed between the mRNA and protein levels probably resulted from intrinsic regulatory mechanisms. Although we have no information on the signalling pathways involved, the $L$. interrogans promoters evaluated appear to behave similarly in both species, suggesting conservation of the regulatory mechanisms higher than expected.
The transcription data complement those obtained by fluorescence measurement from the reporter strains, reinforcing the utility of the promoter-probe vectors as a genetic tool to test promoter activity in L. biflexa.

Validation of the L. biflexa promoter-probe constructs was performed by comparison against the in vitro-induced pathogenic strain. In addition to the protein content, we compared the mRNA profiles produced by the wild-type virulent $L$. interrogans and the PAG reporter strain. Side-by-side analysis of two time-points (1 and $24 \mathrm{~h}$ p.i.) showed that all treatments produced similar patterns of both LigA and GFP expression, the latter being controlled by the native $L$. interrogans PligA promoter (Figure 1 versus 9). 

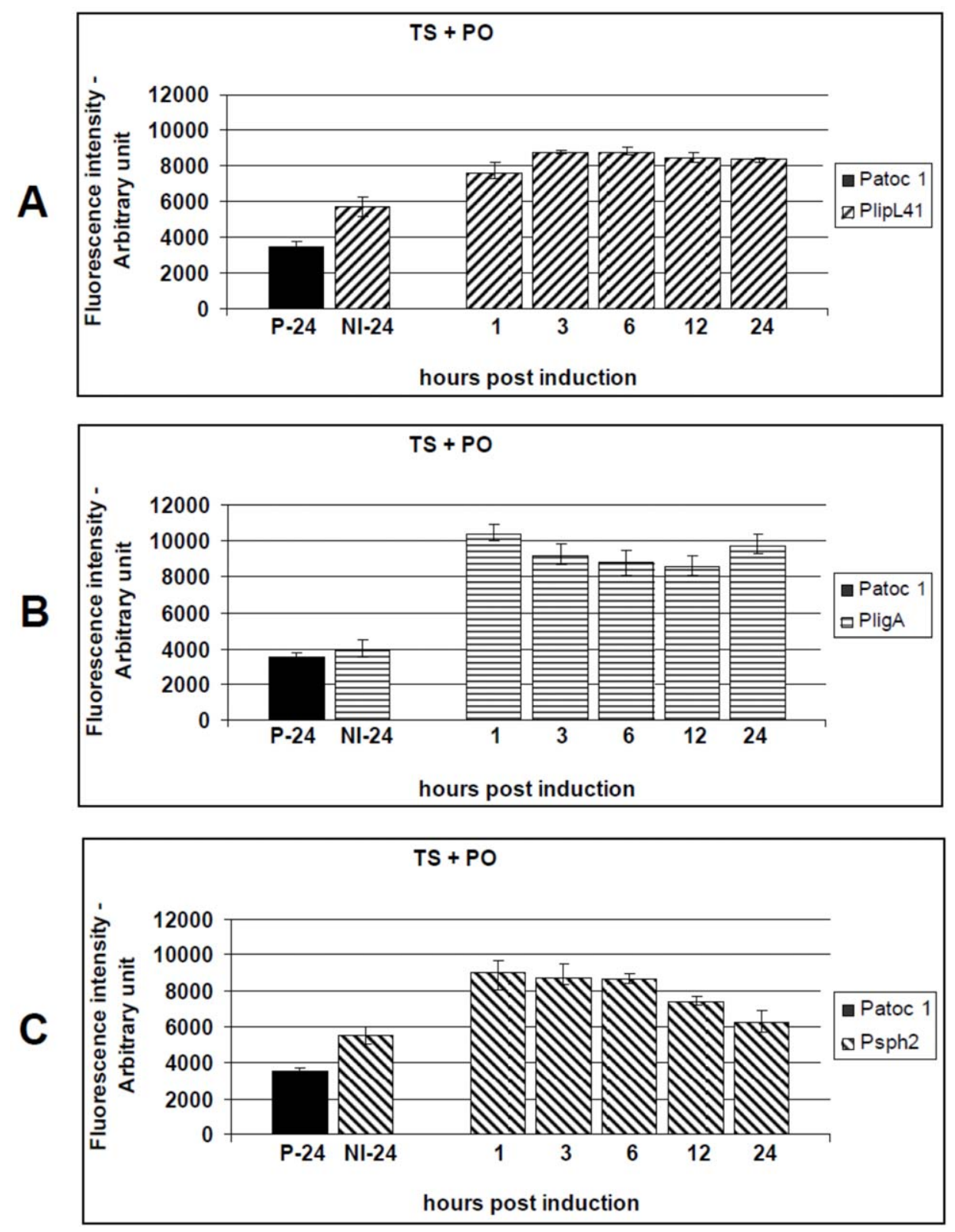

Figure 5. Kinetics of GFP production by the L. biflexa reporter strains (P41G, PAG and P2G) after exposure to a combination of physiological salt levels and temperature upshift to $37^{\circ} \mathrm{C}$. Cultures of the reporter strains P41G (A), PAG (B) or P2G (C) were stimulated by a combination of physiological osmolarity (PO) and temperature upshift (TS). The induced wild-type strain (P-24) and the uninduced reporter strains ( $\mathrm{Nl}-24)$ were included as controls. Transcriptional activity was measured for $24 \mathrm{~h}$ and presented as the mean \pm standard error (bars). Fluorescence from triplicate samples of each culture were standardized according to an $\mathrm{OD}_{420} 0.5$ and are expressed as arbitrary fluorescent units. Data from a representative significant study are shown.

doi:10.1371/journal.pone.0017409.g005

However, a noticeable difference was observed with respect to the transcript levels produced by the native ligA and the PligAcontrolled $g f p$ (Figure 1 versus 9). Of note, up-regulation of the PligA was noted despite the treatment (Table 2), therefore validating the use of this promoter-probe methodology as a genetic tool to assess the ability of pathogens promoters to respond host stimuli.

\section{Discussion}

In this study we developed and characterized in detail a L. biflexa promoter-probe methodology for the analysis of $L$. interrogans promoters. The three promoters regions used in this study resemble regulatory regions of other bacterial species, based on bioinformatics characterization only (data not shown). Although we did not support in silico findings with in vitro data we observed that PlipL41 promoter sequence is similar to the E. coli $\sigma 70$ promoter, while PligA and Psph2 organization is more distant to it. The identification of different repeats into the promoter regions studied may be suggestive of specific response regulator binding sites. It is possible that the elements through which each promoter senses the changes on environmental cues may be different.

The lipL41, ligA and sph2 genes are known to be regulated in vitro by physiological conditions $[44,46,47,48]$. In addition, the $L$. interrogans 

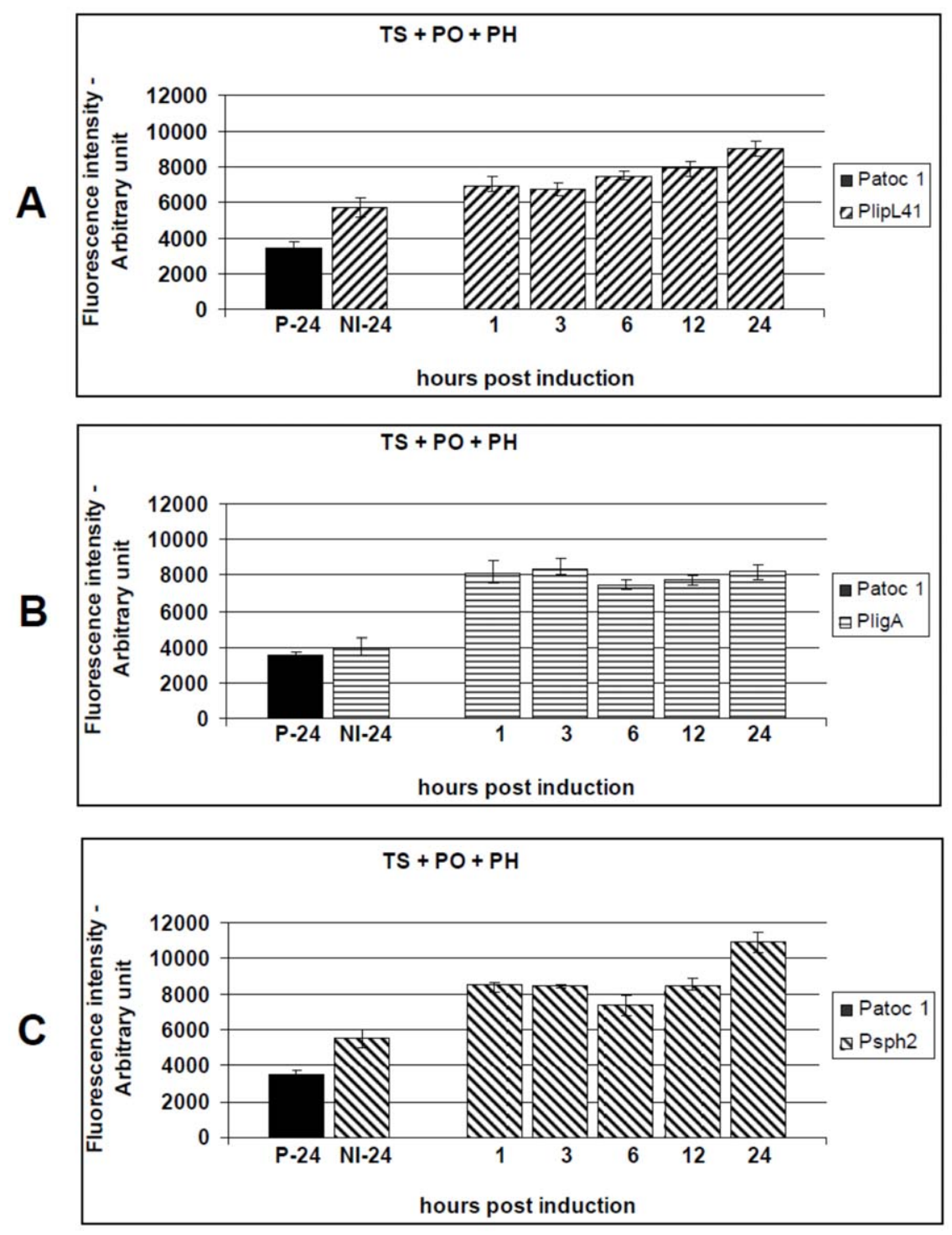

Figure 6. Kinetics of GFP production by the L. biflexa reporter strains (P41G, PAG and P2G), after exposure to a combination of physiological salt levels, temperature upshift to $37^{\circ} \mathrm{C}$ and urine pH 6.7. Cultures of the reporter strains P41G (A), PAG (B) or P2G (C) were induced by a combination of physiological osmolarity (PO), temperature upshift (TS) and pH reduction from 7.2 to 6.7 (PH). The induced wild-type control (P-24) and the uninduced reporter strains (NI-24) were included as controls. Transcriptional activity was measured for $24 \mathrm{~h}$ and presented as the mean \pm standard error (bars). Fluorescence from triplicate samples of each culture were standardized according to an $\mathrm{OD}_{420} 0.5$ and are expressed as arbitrary fluorescent units. Data from a representative significant study are shown. doi:10.1371/journal.pone.0017409.g006

transcriptome was evaluated in response to multifactorial conditions, upon exposure to serum [58]. To further substantiate the knowledge of Leptospira genetics, P41G, PAG and P2G reporter strains were constructed to contain $g f p$ under the conditional control of the aforementioned L. interrogans promoters. Analysis of cell extracts harvested from exponentially growing cultures revealed low GFP activity under routine growth conditions, while variable activity was observed post-induction. In agreement to previous findings obtained by transcriptomics, our data demonstrate the sensitivity of leptospiral promoters under the various conditions evaluated.

ligA is a paralog of $\operatorname{lig} B$, and originated by duplication events of the first ten immunoglobulin-like domains [83], consequently both are expected to respond to host stimuli through similar mechanisms. Both proteins seem to contribute to the pathogenesis of Leptospira spp. as important adhesins $[84,85,86]$. In addition, spectral counts of both proteins by a mass-spectrometry-based strategy revealed that both LigA and LigB are present in 553 and 914 copies per cell, respectively [87]. Recently, Lo and colleagues were not able to detect LigB among $L$. interrogans serovar Lai samples shifted from environmental to human body temperature $\left(37^{\circ} \mathrm{C}\right)$, demonstrating that temperature upshift alone may be insufficient for induction of expression of Lig proteins [88]. Likewise, in our study, the PligA promoter activity was only weakly detected during non-induced and single-condition induced PAG cells. However, fluorescence was more than doubled after induction by combinations of stimuli (Figure 5B-7B). The same was observed for the expression of native LigA by L. interrogans serovar Copenhageni strain Fiocruz L1-130 (Figure 2).

Sph2 is expressed under routine in vitro conditions and temperature upshift to $37^{\circ} \mathrm{C}[87,88,89]$. At the mRNA level, it 

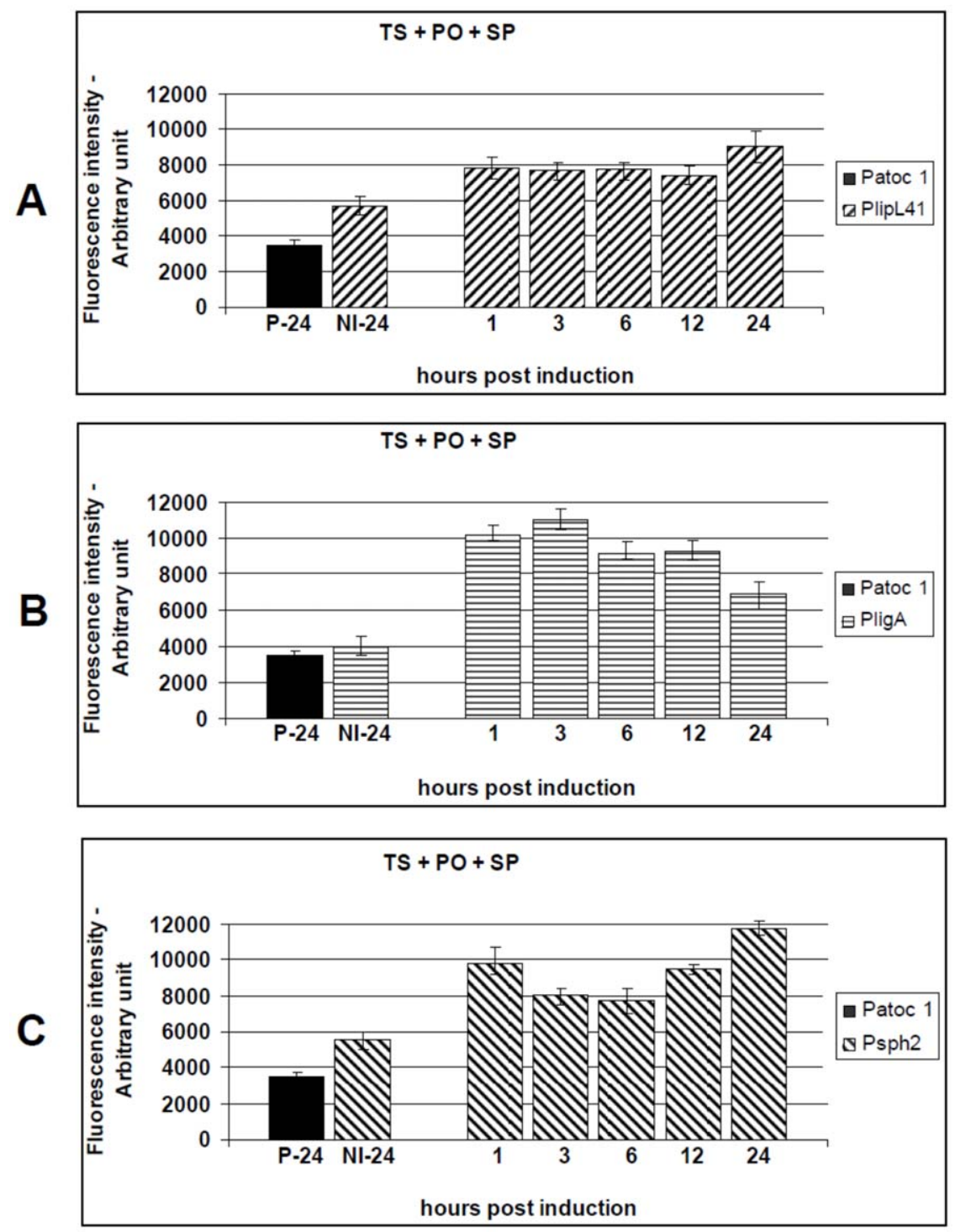

Figure 7. Kinetics of GFP production by the L. biflexa reporter strains (P41G, PAG and P2G), after exposure to a combination of physiological salt levels, temperature upshift to $37^{\circ} \mathrm{C}$ and supplementation with spermine. Cultures of the reporter strains P41G (A), PAG (B) or P2G (C) were induced by a combination of physiological osmolarity (PO), temperature upshift (TS) and $200 \mu \mathrm{M}$ spermine (intracellular level) (SP). The induced wild-type control (P-24) and the uninduced reporter strains ( $\mathrm{NI}-24)$ were included as controls. Transcriptional activity was measured for $24 \mathrm{~h}$ and presented as the mean \pm standard error (bars). Fluorescence from triplicate samples of each culture were standardized according to an $\mathrm{OD}_{420} 0.5$ and are expressed as arbitrary fluorescent units. Data from a representative significant study are shown.

doi:10.1371/journal.pone.0017409.g007

is up-regulated by physiological osmolarity [47] and temperature [46]. In our study, we corroborated these findings with the observation of low levels of fluorescence in the non-induced P2G reporter strain and elevated levels of $P$ sph2 promoter activity after induction by the combination of different mammalian host conditions (Figures 5C, 6, 7C). These findings suggest the mammalian host conditions may have contributed to this effect and reinforces the hypothesis that the sph2 gene is likely to be regulated at post-transcriptional level.

Interestingly, we observed LigA down-regulation when $L$. interrogans serovar Copenhageni was cultivated at $\mathrm{pH} 6.7$ (Figure 2G). This is in agreement with previous findings that leptospiral antigens are down-regulated when leptospires are excreted in the urine [90]. Of note, this was not observed during fluorescence analysis (Figure 6). This suggests that specific response regulators may be triggered in the parental pathogenic strain, during renal colonization and/or urine shedding. In general, the activity of the PlipL41 promoter was not, or only weakly, influenced under the various conditions studied (Figure 3A-7A), and this is consistent with previous observations $[59,88,91,92]$. In contrast to the study of Nally and colleagues [93] that observed LipL41 downregulation upon experimental infection, PlipL41 promoter activity was not reduced when the $\mathrm{P} 41 \mathrm{G}$ reporter strain was cultivated under the majority of the conditions analysed (Figure 3A7A). This suggests that the reduction of LipL41 expression in guinea pig-recovered $L$. interrogans may be due to post translational regulation, and may involve complex regulation systems such as host cell contact, protein degradation, and energy metabolism.

Of note, the PlipL41 promoter was initially selected as a constitutive promoter. However, we noted that this promoter was 
Table 2. Comparison among top fluorescence intensities and protein expression levels reached by the strains in study.

\begin{tabular}{|c|c|c|c|}
\hline \multirow[t]{2}{*}{ Treatments } & \multicolumn{3}{|c|}{ Reporter strain } \\
\hline & P41G & PAG & P2G \\
\hline Physiological osmolarity & 1.11 & 1.48 & 1.03 \\
\hline Temperature upshift to $37^{\circ} \mathrm{C}$ & 1.46 & 1.50 & 1.26 \\
\hline Physiological osmolarity/Temperature upshift & 1.54 & $2.59^{*}$ & 1.62 \\
\hline Physiological osmolarity/Temperature upshift/pH 6.7 & 1.58 & $2.08^{*}$ & $1.96 \dagger$ \\
\hline \multirow[t]{3}{*}{ Physiological osmolarity/Temperature upshift/Spermine } & 1.58 & $2.74^{*}$ & $2.12^{*}$ \\
\hline & \multicolumn{3}{|c|}{ Native protein } \\
\hline & & \multicolumn{2}{|l|}{ LigA } \\
\hline Native protein - Physiological osmolarity/Temperature upshift & NA & $4.98^{*} \dagger$ & NA \\
\hline Native protein - Physiological osmolarity/Temperature upshift/pH 6.7 & NA & $5.92 *+$ & NA \\
\hline Native protein - Physiological osmolarity/Temperature upshift/Spermine & NA & $5.95^{*}+$ & NA \\
\hline
\end{tabular}

also up-regulated at some of the selected time-points. An ideal constitutive gene should exhibit constant activity independently to the cell state or environmental conditions. However, constitutive expression may not be related to constant promoter activity. Moreover, expression levels of constitutive genes such as the flagellin or the ribosomal RNA synthesis genes, have been shown to be altered by temperature-shift or ciprofloxacin supplementation [87,88]. PlipL41 promoter activity was not always induced under the in vitro conditions. In addition, its activity was below the cut-off level (2-fold) established in this work for virulence factor promoters (Table 2). This lead us to believe that the $\mathrm{P} 41 \mathrm{G}$ reporter strain may serve as a negative control in the identification of novel virulence factors.

Although L. interrogans is a pathogen known to infect the mammalian host through active penetration, there is uncertainty over the existence of an intracellular phase during this process. In this study, we demonstrated that spermine, a polyamine found in abundance in eukaryotic cells [76] alters L. interrogans promoters activity. Previous studies showed leptospiral survival and replication within human macrophages, a spermine-rich eukaryotic cell [94]. We observed that supplementation of reporter strain cultures with spermine was able to stimulate promoter activity. In addition, we present evidence that similar transcriptional and translational changes occurred during induction of the native proteins, supporting the hypothesis that pathogenic Leptospira spp. can recognize polyamines as a signal of the intracellular environment. Polyamine recognition is likely a component of a sophisticated system that integrates multiple environmental signals and regulates gene expression in intracellular bacteria, i.e. Francisella [95,96,97], and biofilm formation in Vibrio spp. and Yersinia spp. [77,78]. As polyamines in the intracellular environment are likely to reach elevated levels, our findings on promoter regulation by spermine may be relevant bacterial pathogenesis in general.

It is not known what controls ligA or sph2 transcription initiation. However, previous studies have shown that both genes are upregulated by physiological osmolarity $[44,47,48]$ and temperature [46]. Also, recent work presented evidence of a functional redundancy between LigA and LigB [52]. The finding that the PligA promoter is active under different in vitro conditions, which simulate the mammalian host environment, raises the hypothesis that ligA absence from several pathogenic serovars is likely to be due to spontaneous deleterious events that may have occurred inside or outside the mammalian host environment [83,98], without any influence on virulence or pathogenicity. Since most of the conditions studied induced constant activity of PligA in vitro (Figure 3B-6B), it is possible that LigA may contribute to the early stages in the course of leptospirosis. The kinetics of native LigA expression also supports this hypothesis, although protein levels did vary (Figure 2).

We found that native LigA was up-regulated upon induction by the combined conditions of physiological osmolarity, temperature upshift to $37^{\circ} \mathrm{C}$ and spermine, with a 5.95 -fold increase. The corresponding reporter strain, PAG, was up-regulated by the same treatment (2.74-fold), demonstrating a good correlation between the promoter-probe methodology and native protein expression in $L$. interrogans, suggesting that LigA is post-transcriptionally regulated (Table 2). This also suggests that L. interrogans protein expression may involve particular mechanisms or pathways to respond to specific host stimuli. The overall up-regulation of native LigA observed in comparison to the non-induced control was in agreement with the induction of the L. biflexa PAG reporter strain. Our results are in concordance with previous studies whereby the lig genes were expressed in vitro at both transcript and proteins levels [99], although a previous study using an L. interrogans serovar Pomona type Kennewicki strain was only able to detect the lig genes at the transcript level, [100]. We believe that these differences may be due to the different strains used. Moreover, $\operatorname{lig} B$ a paralogous gene to ligA, was up-regulated by an overnight temperature upshift from $30^{\circ} \mathrm{C}$ to $37^{\circ} \mathrm{C}$ (1.7-fold). Yet, physiological osmolarity stimulated ligA and ligB up-regulation (4.41 to 5.27fold - based on the transcriptional signals employing oligonucleotides to both the $\operatorname{lig} A / \operatorname{lig} B$ identical region and the $\operatorname{lig} B$ unique region, respectively) $[46,48]$. Additionally, a recent study evaluated the influence of serum on $\operatorname{lig} B$ up-regulation (1.89-fold) [58]. Although we did not quantify the transcription of the ligA gene, a clear variation was observed in comparison to the non-induced controls, which is in agreement with previous findings (Figure 1). This reinforces the applicability of the promoter-probe vectors to 


\section{Transmitted light}

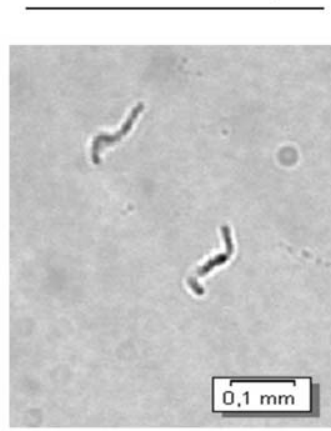

Patoc 1
Non induced reporter strain

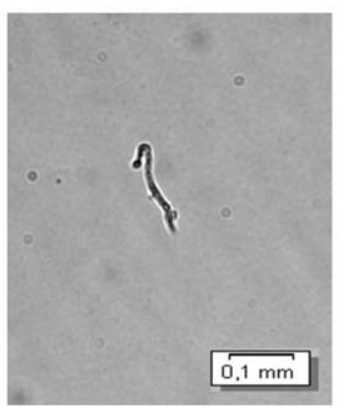

Ultra-violet
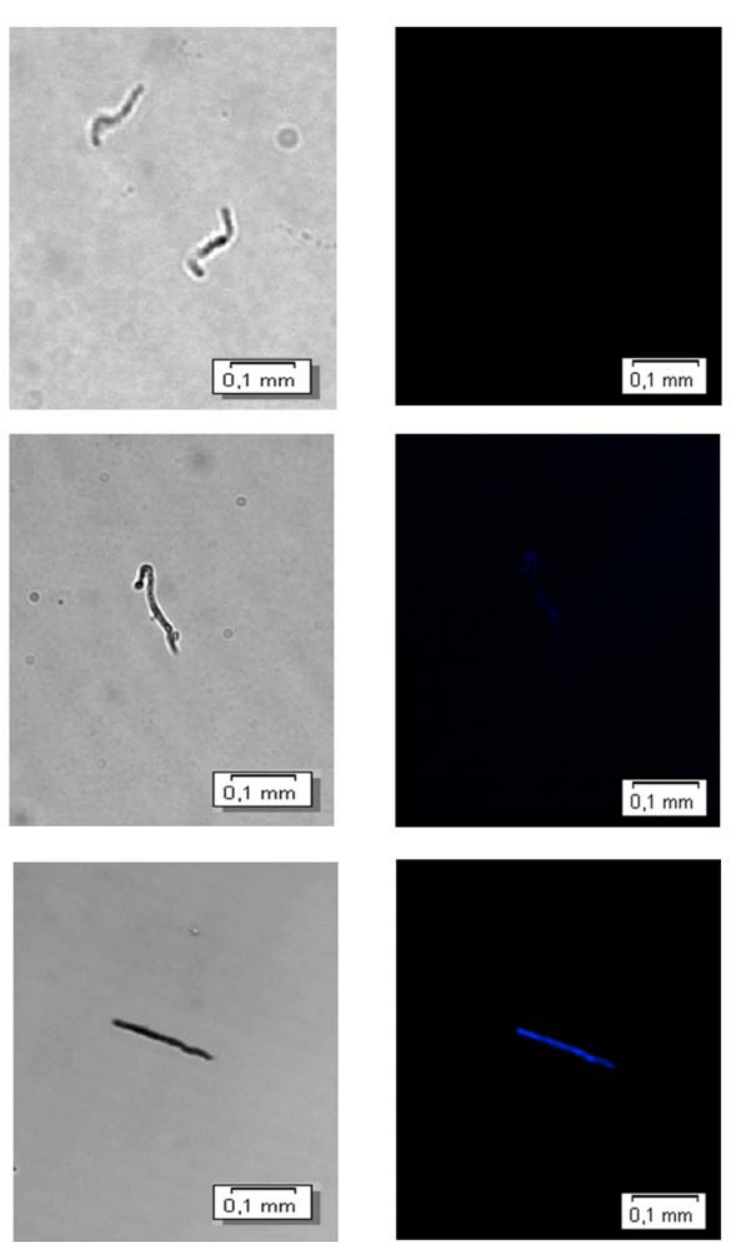

Figure 8. Inducible expression of GFP in the L. biflexa promoter-probe constructs. Microscope images of the in vitro induced and uninduced P2G reporter strain transformed with pSLe94-sph2 promoter-gfp vector. Uninduced and physiological osmolarity/temperature upshift/ spermine exposed leptospires were fixed and visualized by phase contrast and by GFP fluorescence. Wild-type L. biflexa str. Patoc 1 was used as the negative control.

doi:10.1371/journal.pone.0017409.g008

assess promoter activity in L. biflexa. Based on these results, we conclude that $(i)$ the combination of the in vitro conditions reliably simulated the host environment, (ii) L. biflexa can be used as a model to characterize L. interrogans promoters and (iii) this promoter-probe methodology may be helpful in the prediction of potential virulence factors of pathogenic Leptospira spp. Furthermore, previous studies showed ligA gene up-regulation shortly after temperature upshift [46,88], thus reinforcing the hypothesis that LigA may contribute to the early stages of infection and host adaptation. In addition, the Psph2 promoter was upregulated in the presence of spermine (2.12-fold).

We observed some conflicting evidence in the correlation between native ligA mRNA and LigA abundance levels (Figure 1 versus 2), similar to previous studies [88,101,102,103,104]. As previously suggested by Lo and colleagues [88], it is possible that the lack of correlation might be due to the longer half-life, greater stability or post transcriptional regulation of the mRNA transcript, i.e. as a result of the activity of small non-coding RNAs. Native LigA was detected at very low levels in the non-induced $L$. interrogans cells, while a significant up-regulation, at similar rates to recent studies [48], was observed when leptospires were grown under mammalian host conditions. In light of this information, we may conclude that the expression of both LigA and Sph2 is likely to be regulated at the post-transcriptional level.

Despite advances in the development of genetic tools for Leptospira spp. some basic questions remain unanswered. It is still unclear what regulators and pathways are associated with the expression of virulence factors. The level at which members of a given regulatory cascade exert induction/repression of transcription of LigA, Sph2 and other virulence factors is unknown. In this sudy we demonstrate that L. biflexa can serve as a model to study the genetics of $L$. interrogans. The pathogen-derived promoters exhibited activity in the L. biflexa, suggesting the existence of shared regulatory mechanisms among the saprophytes and pathogenic Leptospira spp. In addition, the establishment of a cut-off based on the promoter activity of virulence and non-virulence factors (Table 2), and the different fluorescence levels expressed by the reporter strains upon induction eliminated the possibility that the effects were simply due to stress responses. Furthermore, the suite of promoter-probe vectors developed in this study can be modified to make diverse translational fusions to investigate protein expression patterns 
TS + PO

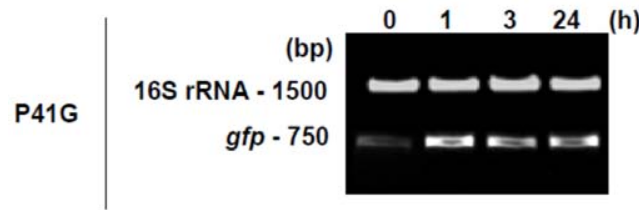

(bp)

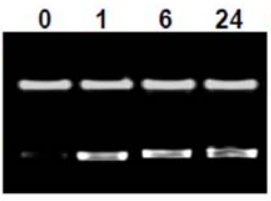

PAG

$16 S$ rRNA - 1500

gfp -750

(bp)

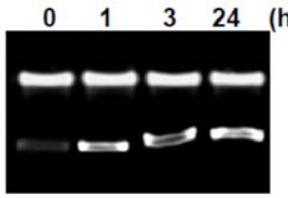

$\mathrm{TS}+\mathrm{PO}+\mathrm{SP}$
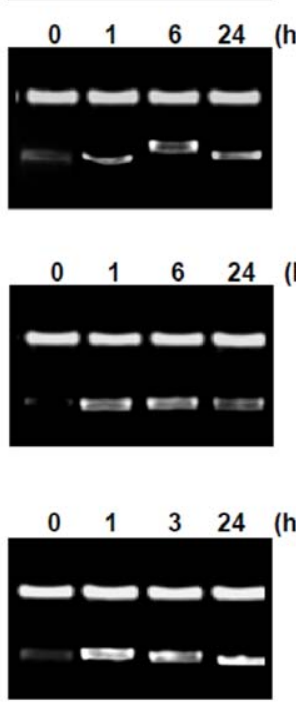

$\mathrm{TS}+\mathrm{PO}+\mathrm{PH}$
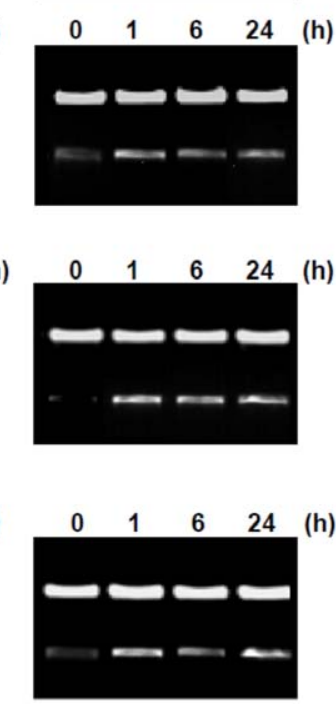

Figure 9. Influence of the in vitro conditions on gfp expression of the reporter strains. The effect of each of the combinations of conditions on promoter activity was assessed by the level of gfp mRNA produced. Rows depict the reporter strains in this study, while columns show the various conditions used: TS - Temperature upshift from $30^{\circ} \mathrm{C}$ to $37^{\circ} \mathrm{C}$; PO - Physiological osmolarity; SP - Spermine induction; $\mathrm{PH}-\mathrm{Urine} \mathrm{pH}$ induction. Within each lane, the upper band represents the internal PCR control (16S rRNA) and the lower band corresponds to the gfp CDNA amplified by rtPCR. The lanes in each gel contain the amplified CDNA per time-point, both pretreatment $(0 \mathrm{~h})$ and post induction $(1,3$ or 6 and 24 h). Agarose gels were stained with GelRed (Invitrogen). No bands were observed in control samples run without template (data not shown). Samples were standardized according to an $\mathrm{OD}_{420} 0.25$. Data from a representative significant study are shown.

doi:10.1371/journal.pone.0017409.g009

and complex regulatory networks involved in leptospiral protein regulation.

In conclusion, this study demonstrates the potential of a novel genetic tool for the identification and characterization of virulence factors of Leptospira spp. Our transcription and expression findings suggest that a combination of in vitro signals may be important to accurately simulate the host environment. We expect to provide further information towards understanding Leptospira spp. genetics and that will eventually serve as a basis for further studies. The understanding of the extent to which leptospiral promoters are regulated by mammalian host conditions, as well as the expression kinetics, may reveal useful information about the biology of Leptospira spp. A knock-in mutant library of different promoters is currently under construction with this in mind.

\section{References}

1. McBride AJ, Athanazio DA, Reis MG, Ko AI (2005) Leptospirosis. Curr Opin Infect Dis 18: 376-386.

2. Bharti AR, NallyJE, RicaldiJN, Matthias MA, Diaz MM, et al. (2003) Leptospirosis: a zoonotic disease of global importance. Lancet Infect Dis 3: 757-771.

3. Segura ER, Ganoza CA, Campos K, Ricaldi JN, Torres S, et al. (2005) Clinical spectrum of pulmonary involvement in leptospirosis in a region of endemicity, with quantification of leptospiral burden. Clin Infect Dis 40: 343-351.

4. Gouveia EL, Metcalfe J, de Carvalho AL, Aires TS, Villasboas-Bisneto JC, et al. (2008) Leptospirosis-associated severe pulmonary hemorrhagic syndrome, Salvador, Brazil. Emerg Infect Dis 14: 505-508.

5. Cerqueira GM, Picardeau M (2009) A century of Leptospira strain typing. Infect Genet Evol 9: 760-768.

6. Faine S, Adler B, Bolin C, Perolat P (1999) Leptospira and Leptospirosis. Melbourne: MedScience.

7. Levett PN (2001) Leptospirosis. Clin Microbiol Rev 14: 296-326.

8. Ren SX, Fu G, Jiang XG, Zeng R, Miao YG, et al. (2003) Unique physiological and pathogenic features of Leptospira interrogans revealed by whole-genome sequencing. Nature 422: 888-893.

9. Nascimento AL, Ko AI, Martins EA, Monteiro-Vitorello CB, Ho PL, et al. (2004) Comparative genomics of two Leptospira interrogans serovars reveals novel insights into physiology and pathogenesis. J Bacteriol 186: 2164-2172.

\section{Acknowledgments}

We thank Dr. Marilene Demasi, Dr. Hugo A. Armelin and Dr. Toshie Kawano for their support with fluorescence and microscopy facilities, and Alexsander Seixas de Souza, Ivan N. Avino and Bogar O. A. Montoya for technical assistance with the experiments. We are also grateful to Dr. Mathieu Picardeau, Dr. Justin D. Radolf and Dr. Alan J. A. McBride for helpful comments and critical reviews of the manuscript.

\section{Author Contributions}

Conceived and designed the experiments: GMC ALTON. Performed the experiments: GMC NMS ERA ATB ZMM. Analyzed the data: GMC ALTON. Contributed reagents/materials/analysis tools: GMC SAV ALTON. Wrote the paper: GMC SAV ALTON

10. Bulach DM, Zuerner RL, Wilson P, Seemann T, McGrath A, et al. (2006) Genome reduction in Leptospira borgpetersenii reflects limited transmission potential. Proc Natl Acad Sci U S A 103: 14560-14565.

11. Picardeau M, Bulach DM, Bouchier C, Zuerner RL, Zidane N, et al. (2008) Genome sequence of the saprophyte Leptospira biflexa provides insights into the evolution of Leptospira and the pathogenesis of leptospirosis. PLoS One 3: e1607.

12. World Health Organization (2003) Human Leptospirosis: Guidance for Diagnosis, Surveillance and Control. Malta.

13. Levett PN (2003) Usefulness of serologic analysis as a predictor of the infecting serovar in patients with severe leptospirosis. Clin Infect Dis 36: 447-452.

14. Bajani MD, Ashford DA, Bragg SL, Woods CW, Aye T, et al. (2003) Evaluation of four commercially available rapid serologic tests for diagnosis of leptospirosis. J Clin Microbiol 41: 803-809.

15. Effler PV, Bogard AK, Domen HY, Katz AR, Higa HY, et al. (2002) Evaluation of eight rapid screening tests for acute leptospirosis in Hawaii.J Clin Microbiol 40: 1464-1469.

16. Smits HL, Ananyina YV, Chereshsky A, Dancel L, Lai AFRF, et al. (1999) International multicenter evaluation of the clinical utility of a dipstick assay for detection of Leptospira-specific immunoglobulin M antibodies in human serum specimens. J Clin Microbiol 37: 2904-2909. 
17. Smits HL, Hartskeerl RA, Terpstra WJ (2000) International multi-centre evaluation of a dipstick assay for human leptospirosis. Trop Med Int Health 5: 124-128.

18. Smits HL, Chee HD, Eapen CK, Kuriakose M, Sugathan S, et al. (2001) Latex based, rapid and easy assay for human leptospirosis in a single test format. Trop Med Int Health 6: 114-118.

19. Smits HL, Eapen CK, Sugathan S, Kuriakose M, Gasem MH, et al. (2001) Lateral-flow assay for rapid serodiagnosis of human leptospirosis. Clin Diagn Lab Immunol 8: 166-169.

20. Sonrier C, Branger C, Michel V, Ruvoen-Clouet N, Ganiere JP, et al. (2000) Evidence of cross-protection within Leptospira interrogans in an experimental model. Vaccine 19: 86-94.

21. Bolin CA, Thiermann AB, Handsaker AL, Foley JW (1989) Effect of vaccination with a pentavalent leptospiral vaccine on Leptospira interrogans serovar hardjo type hardjo-bovis infection of pregnant cattle. Am J Vet Res 50: $161-165$.

22. Croda J, Ramos JG, Matsunaga J, Queiroz A, Homma A, et al. (2007) Leptospira immunoglobulin-like proteins as a serodiagnostic marker for acute leptospirosis. J Clin Microbiol 45: 1528-1534.

23. Oliveira TR, Longhi MT, de Morais ZM, Romero EC, Blanco RM, et al. (2008) Evaluation of leptospiral recombinant antigens MPL17 and MPL21 for serological diagnosis of leptospirosis by enzyme-linked immunosorbent assays. Clin Vaccine Immunol 15: 1715-1722.

24. Dong H, Hu Y, Xue F, Sun D, Ojcius DM, et al. (2008) Characterization of the ompL1 gene of pathogenic Leptospira species in China and cross-immunogenicity of the OmpL1 protein. BMC Microbiol 8: 223.

25. Lin X, Chen Y, Yan J (2008) Recombinant multiepitope protein for diagnosis of leptospirosis. Clin Vaccine Immunol 15: 1711-1714.

26. Srimanote P, Wongdeethai N, Jieanampunkul P, Samonkiert S, Leepiyasakulchai C, et al. (2008) Recombinant ligA for leptospirosis diagnosis and ligA among the Leptospira spp. clinical isolates. J Microbiol Methods 72: 73-81.

27. Bomfim MR, Ko A, Koury MC (2005) Evaluation of the recombinant LipL32 in enzyme-linked immunosorbent assay for the serodiagnosis of bovine leptospirosis. Vet Microbiol 109: 89-94.

28. Dey S, Mohan CM, Kumar TM, Ramadass P, Nainar AM, et al. (2004) Recombinant LipL32 antigen-based single serum dilution ELISA for detection of canine leptospirosis. Vet Microbiol 103: 99-106.

29. Haake DA, Mazel MK, McCoy AM, Milward F, Chao G, et al. (1999) Leptospiral outer membrane proteins OmpL1 and LipL41 exhibit synergistic immunoprotection. Infect Immun 67: 6572-6582.

30. Koizumi N, Watanabe H (2004) Leptospiral immunoglobulin-like proteins elicit protective immunity. Vaccine 22: 1545-1552.

31. Branger C, Chatrenet B, Gauvrit A, Aviat F, Aubert A, et al. (2005) Protection against Leptospira interrogans sensu lato challenge by DNA immunization with the gene encoding hemolysin-associated protein 1. Infect Immun 73: 4062-4069.

32. Palaniappan RU, McDonough SP, Divers TJ, Chen CS, Pan MJ, et al. (2006) Immunoprotection of recombinant leptospiral immunoglobulin-like protein A against Leptospira interrogans serovar Pomona infection. Infect Immun 74: $1745-1750$

33. Silva EF, Medeiros MA, McBride AJ, Matsunaga J, Esteves GS, et al. (2007) The terminal portion of leptospiral immunoglobulin-like protein LigA confers protective immunity against lethal infection in the hamster model of leptospirosis. Vaccine 25: 6277-6286.

34. Faisal SM, Yan W, McDonough SP, Pan MJ, Chang CF, et al. (2009) Leptosome-associated leptospiral antigens conferred significant higher levels of protection than those associated with PC-liposomes in a hamster model. Vaccine

35. Yan W, Faisal SM, McDonough SP, Divers TJ, Barr SC, et al. (2009) Immunogenicity and protective efficacy of recombinant Leptospira immunoglobulin-like protein $\mathrm{B}(\mathrm{rLigB})$ in a hamster challenge model. Microbes Infect 11: 230-237.

36. Faisal SM, Yan W, McDonough SP, Chang YF (2009) Leptospira immunoglobulin-like protein A variable region (LigAvar) incorporated in liposomes and PLGA microspheres produces a robust immune response correlating to protective immunity. Vaccine 27: 378-387.

37. Faisal SM, Yan W, Chen CS, Palaniappan RU, McDonough SP, et al. (2008) Evaluation of protective immunity of Leptospira immunoglobulin like protein A (LigA) DNA vaccine against challenge in hamsters. Vaccine 26: 277-287.

38. Chang YF, Chen CS, Palaniappan RU, He H, McDonough SP, et al. (2007) Immunogenicity of the recombinant leptospiral putative outer membrane proteins as vaccine candidates. Vaccine 25: 8190-8197.

39. Yan W, Faisal SM, McDonough SP, Chang CF, Pan MJ, et al. Identification and characterization of OmpA-like proteins as novel vaccine candidates for Leptospirosis. Vaccine 28: 2277-2283.

40. Faisal SM, Yan W, McDonough SP, Chang CF, Pan MJ, et al. (2009) Leptosome-entrapped leptospiral antigens conferred significant higher levels of protection than those entrapped with PC-liposomes in a hamster model. Vaccine 27: 6537-6545.

41. Faisal SM, Yan W, McDonough SP, Mohammed HO, Divers TJ, et al. (2009) Immune response and prophylactic efficacy of smegmosomes in a hamster model of leptospirosis. Vaccine 27: 6129-6136.

42. Bourhy P, Louvel H, Saint GI, Picardeau M (2005) Random insertional mutagenesis of Leptospira interrogans, the agent of leptospirosis, using a mariner transposon. Journal of Bacteriology 187: 3255-3258.
43. Aviat F, Slamti L, Cerqueira GM, Lourdault K, Picardeau M (2010) Expanding the Genetic Toolbox for Leptospira Species by Generation of Fluorescent Bacteria. Appl Environ Microbiol 76: 8135-8142.

44. Matsunaga J, Sanchez Y, Xu X, Haake DA (2005) Osmolarity, a key environmental signal controlling expression of leptospiral proteins LigA and LigB and the extracellular release of LigA. Infect Immun 73: 70-78.

45. Barbosa AS, Abreu PA, Neves FO, Atzingen MV, Watanabe MM, et al. (2006) A newly identified leptospiral adhesin mediates attachment to laminin. Infect Immun 74: 6356-6364.

46. Lo M, Bulach DM, Powell DR, Haake DA, Matsunaga J, et al. (2006) Effects of temperature on gene expression patterns in Leptospira interrogans serovar Lai as assessed by whole-genome microarrays. Infect Immun 74: 5848-5859.

47. Matsunaga J, Medeiros MA, Sanchez Y, Werneid KF, Ko AI (2007) Osmotic regulation of expression of two extracellular matrix-binding proteins and a haemolysin of Leptospira interrogans: differential effects on LigA and Sph2 extracellular release. Microbiology 153: 3390-3398.

48. Matsunaga J, Lo M, Bulach DM, Zuerner RL, Adler B, et al. (2007) Response of Leptospira interrogans to physiologic osmolarity: relevance in signaling the environment-to-host transition. Infect Immun 75: 2864-2874.

49. Atzingen MV, Barbosa AS, De Brito T, Vasconcellos SA, de Morais ZM, et al. (2008) Lsa21, a novel leptospiral protein binding adhesive matrix molecules and present during human infection. BMC Microbiol 8: 70.

50. Ristow P, Bourhy P, da Cruz McBride FW, Figueira CP, Huerre M, et al. (2007) The OmpA-like protein Loa22 is essential for leptospiral virulence. PLoS Pathog 3: e97.

51. Stevenson B, Choy HA, Pinne M, Rotondi ML, Miller MC, et al. (2007) Leptospira interrogans endostatin-like outer membrane proteins bind host fibronectin, laminin and regulators of complement. PLoS One 2: e1188.

52. Croda J, Figueira CP, Wunder EA, Jr., Santos CS, Reis MG, et al. (2008) Targeted mutagenesis in pathogenic Leptospira species: disruption of the LigB gene does not affect virulence in animal models of leptospirosis. Infect Immun 76: $5826-5833$

53. Murray GL, Srikram A, Henry R, Puapairoj A, Sermswan RW, et al. (2009) Leptospira interrogans requires heme oxygenase for disease pathogenesis. Microbes Infect 11: 311-314

54. Murray GL, Srikram A, Hoke DE, Wunder EA, Jr., Henry R, et al. (2009) Major surface protein LipL32 is not required for either acute or chronic infection with Leptospira interrogans. Infect Immun 77: 952-958.

55. Murray GL, Morel V, Cerqueira GM, Croda J, Srikram A, et al. (2009) Genome-wide transposon mutagenesis in pathogenic Leptospira species. Infect Immun 77: 810-816.

56. Murray GL, Ellis KM, Lo M, Adler B (2008) Leptospira interrogans requires a functional heme oxygenase to scavenge iron from hemoglobin. Microbes Infect 10: 791-797.

57. Xue F, Dong H, Wu J, Wu Z, Hu W, et al. (2010) Transcriptional responses of Leptospira interrogans to host innate immunity: significant changes in metabolism, oxygen tolerance, and outer membrane. PLoS Negl Trop Dis 4: e857.

58. Patarakul K, Lo M, Adler B (2010) Global transcriptomic response of Leptospira interrogans serovar Copenhageni upon exposure to serum. BMC Microbiol 10.

59. Cullen PA, Cordwell SJ, Bulach DM, Haake DA, Adler B (2002) Global analysis of outer membrane proteins from Leptospira interrogans serovar Lai. Infect Immun 70: 2311-2318.

60. Haake DA, Martinich C, Summers TA, Shang ES, Pruetz JD, et al. (1998) Characterization of leptospiral outer membrane lipoprotein LipL36: downregulation associated with late-log-phase growth and mammalian infection. Infect Immun 66: 1579-1587.

61. Matsunaga J, Young TA, Barnett JK, Barnett D, Bolin CA, et al. (2002) Novel 45-kilodalton leptospiral protein that is processed to a 31-kilodalton growthphase-regulated peripheral membrane protein. Infect Immun 70: 323-334.

62. Nally JE, Artiushin S, Timoney JF (2001) Molecular characterization of thermoinduced immunogenic proteins Q1p42 and Hsp15 of Leptospira interrogans. Infect Immun 69: 7616-7624.

63. Barnett JK, Barnett D, Bolin CA, Summers TA, Wagar EA, et al. (1999) Expression and distribution of leptospiral outer membrane components during renal infection of hamsters. Infect Immun 67: 853-861.

64. Ko AI, Goarant C, Picardeau M (2009) Leptospira: the dawn of the molecular genetics era for an emerging zoonotic pathogen. Nat Rev Microbiol 7: 736-747.

65. Ellinghausen HC, Jr., McCullough WG (1965) Nutrition of Leptospira Pomona and Growth of 13 Other Serotypes: Fractionation of Oleic Albumin Complex and a Medium of Bovine Albumin and Polysorbate 80. Am J Vet Res 26: $45-51$.

66. Johnson RC, Harris VG (1967) Differentiation of pathogenic and saprophytic letospires. I. Growth at low temperatures. J Bacteriol 94: 27-31.

67. Vallenet D, Labarre L, Rouy Z, Barbe V, Bocs S, et al. (2006) MaGe - a microbial genome annotation system supported by synteny result. Nucleic Acids Research 34: 13.

68. Reese MG (2001) Application of a time-delay neural network to promoter annotation in the Drosophila melanogaster genome. Computational Chemistry 26: 6 .

69. Matys V, Fricke E, Geffers R, Gossling E, Haubrock M, et al. (2003) TRANSFAC: transcriptional regulation, from patterns to profiles. Nucl Acids Res 31: 5. 
70. Studholme DJ, Dixon R (2003) Domain architectures of sigma 54-dependent transcriptional activators. J Bacteriol 185: 11

71. Girons IS, Bourhy P, Ottone C, Picardeau M, Yelton D, et al. (2000) The LE1 bacteriophage replicates as a plasmid within Leptospira biflexa: construction of an L. biflexa-Escherichia coli shuttle vector. J Bacteriol 182: 5700-5705.

72. Weisburg WG, Barns SM, Pelletier DA, Lane DJ (1991) 16S ribosomal DNA amplification for phylogenetic study. J Bacteriol 173: 7.

73. Matsunaga J, Werneid K, Zuerner RL, Frank A, Haake DA (2006) LipL46 is a novel surface-exposed lipoprotein expressed during leptospiral dissemination in the mammalian host. Microbiology 152: 3777-3786.

74. GraphPad Software. Available: http://www.graphpad.com.

75. Carlson JPE, Horzempa J, O'Dee DM, Robinson CM, Neophytou P, et al. (2009) Global transcriptional response to spermine, a component of the intramacrophage environment, reveals regulation of Francisella gene expression through insertion sequence elements. J Bacteriol 191: 10.

76. Igarashi K, Kashiwagi K (2000) Polyamines: mysterious modulators of cellular functions. Biochem Biophys Res Commun 271: 6.

77. Karatan E, Duncan TR, Watnick PI (2005) NspS, a predicted polyamine sensor, mediates activation of Vibrio cholerae biofilm formation by nor spermidine. J Bacteriol 187: 10.

78. Patel CN, Wortham BW, Lines JL, Fetherston JD, Perry RD, et al. (2006) Polyamines are essential for the formation of plague biofilm. J Bacteriol 188: 9.

79. Ware D, Jiang Y, Lin W, Swiatlo E (2006) Involvement of potD in Streptococcus pneumoniae polyamine transport and pathogenesis. Infect Immun 74: 10.

80. Yoshida M, Kashiwagi K, Shigemasa A, Taniguchi S, Yamamoto K, et al. (2004) A unifying model for the role of polyamines in bacterial cell growth, the polyamine modulon. J Biol Chem 279: 6.

81. Segal GM, Stueve T, Adamson JW (1987) Spermine and spermidine are nonspecific inhibitors of in vitro Hematopoiesis. Kidney Int 31: 5 .

82. Zahedi K, Bissler JJ, Wang Z, Josyula A, Lu L, et al. (2007) Spermidine/ spermine N1-acetyltransferase overexpression in kidney epithelial cells disrupts polyamine homeostasis, leads to DNA damage, and causes G2 arrest. Am J Physiol Cell Physiol 292: 12.

83. McBride AJ, Cerqueira GM, Suchard MA, Moreira AN, Zuerner RL, et al. (2009) Genetic diversity of the Leptospiral immunoglobulin-like (lig) genes in pathogenic Leptospira spp. Infect Genet Evol 9: 196-205.

84. Matsunaga J, Barocchi MA, Croda J, Young TA, Sanchez Y, et al. (2003) Pathogenic Leptospira species express surface-exposed proteins belonging to the bacterial immunoglobulin superfamily. Mol Microbiol 49: 929-945.

85. Barocchi MA, Ko AI, Reis MG, McDonald KL, Riley LW (2002) Rapid translocation of polarized MDCK cell monolayers by Leptospira interrogans, an invasive but nonintracellular pathogen. Infect Immun 70: 6926-6932.

86. Choy HA, Kelley MM, Chen TL, Moller AK, Matsunaga J, et al. (2007) Physiological osmotic induction of Leptospira interrogans adhesion: LigA and LigB bind extracellular matrix proteins and fibrinogen. Infect Immun 75: 2441-2450.

87. Malmstrom J, Beck M, Schimidt A, Lange V, Deutch EW, et al. (2009) Proteome-wide cellular protein concentrations of the human pathogen Leptospira interrogans. Nature 460: 4.
88. Lo M, Cordwell SJ, Bulach DM, Adler B (2009) Comparative transcriptional and translational analysis of leptospiral outer membrane protein expression in response to temperature. PLoS Negl Trop Dis 3: e560.

89. Artiushin S, Timoney JF, Nally J, Verma A (2004) Host-inducible immunogenic sphingomyelinase-like protein, Lk73.5, of Leptospira interrogans. Infect Immun 72: 742-749.

90. Monahan AM, Callanan JJ, Nally JE (2008) Proteomic analysis of Leptospira interrogans shed in urine of chronically infected hosts. Infect Immun 76: 4952-4958.

91. Nally JE, Timoney JF, Stevenson B (2001) Temperature-regulated protein synthesis by Leptospira interrogans. Infect Immun 69: 400-404.

92. Haake DA, Chao G, Zuerner RL, Barnett JK, Barnett D, et al. (2000) The leptospiral major outer membrane protein LipL32 is a lipoprotein expressed during mammalian infection. Infect Immun 68: 2276-2285.

93. Nally JE, Whitelegge JP, Bassilian S, Blanco DR, Lovett MA (2007) Characterization of the outer membrane proteome of Leptospira interrogans expressed during acute lethal infection. Infect Immun 75: 766-773.

94. Li S, Ojcius DM, Liao S, Li L, Xue F, et al. (2009) Replication or death: distinct fates of pathogenic Leptospira strain Lai within macrophages of human or mouse origin. Innate Immun.

95. Deng K, Blick RJ, Liu W, Hansen EJ (2006) Identification of Francisella tularensis genes affected by iron limitation. Infect Immun 74: 13.

96. Horzempa J, Carlson JPE, O’Dee DM, Shanks RM, Nau GJ (2008) Global transcriptional response to mammalian temperature provides new insight into Francisella tularensis pathogenesis. BMC Microbiol 8.

97. Horzempa J, Tarwacki DM, Carlson JPE, Robinson CM, Nau GJ (2008) Characterization and application of a glucose-repressible promoter in Francisella tularensis. Appl Environ Microbiol 74: 10

98. Cerqueira GM, McBride AJ, Picardeau M, Ribeiro SG, Moreira AN, et al. (2009) Distribution of the leptospiral immunoglobulin-like (lig) genes in pathogenic Leptospira species and application of $\operatorname{lig} B$ to typing leptospiral isolates. J Med Microbiol 58: 1173-1181.

99. Matsunaga J, Barocchi MA, Croda J, Young TA, Sanchez Y, et al. (2003) Pathogenic Leptospira species express surface-exposed proteins belonging to the bacterial immunoglobulin superfamily. Molecular Microbiology 49: 929-945.

100. Palaniappan RU, Chang YF, Hassan F, McDonough SP, Pough M, et al (2004) Expression of leptospiral immunoglobulin-like protein by Leptospira interrogans and evaluation of its diagnostic potential in a kinetic ELISA. J Med Microbiol 53: 975-984

101. Ross PL, Huang YN, Marchese JN, Williamson B, Parker K, et al. (2004) Multiplexed protein quantitation in Saccharomyces cerevisiae using aminereactive isobaric tagging reagents. Mol Cell Proteomics 3: 16 .

102. Nie L, Wu G, Zgang W (2006) Correlation of mRNA expression and protein abundance affected by multiple sequence features related to translational efficiency in Desulfovibrio vulgaris: a quantitative analysis. Genetics 174: 15.

103. Suzuki I, Simon WJ, Slabas AR (2006) The heat shock response of Synechocystis sp. PCC 6803 analysed by transcriptomics and proteomics. J Exp Bot 57: 6.

104. Chong PK, Burja AM, Radianingtyas H, Fazeli A, Wright PC (2007) Translational and transcriptional analysis of Sulfolobus solfataricus $\mathrm{P} 2$ to provide insights into alcohol and ketone utilisation. Proteomics 7: 12. 